\title{
Site U1332
}

\author{
Expedition 320/321 Scientists ${ }^{2}$
}

\section{Chapter contents}

Background and objectives. ..........

Science summary................

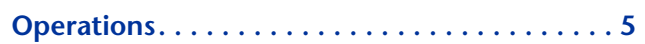

Lithostratigraphy...............

Biostratigraphy ................. 11

Paleomagnetism ................ 14

Geochemistry ................ 16

Physical properties .............. 18

Stratigraphic correlation and composite

section................... 20

Downhole measurements ........... 21

References.................22

Figures..................... 25

Tables.......................69

${ }^{1}$ Expedition 320/321 Scientists, 2010. Site U1332. In Pälike, H., Lyle, M., Nishi, H., Raffi, I., Gamage, K., Klaus, A., and the Expedition 320/321

Scientists, Proc. IODP, 320/321: Tokyo (Integrated Ocean Drilling Program Management International, Inc.).

doi:10.2204/iodp.proc.320321.104.2010

'Expedition 320/321 Scientists' addresses.

\section{Background and objectives}

Integrated Ocean Drilling Program (IODP) Site U1332 $\left(11^{\circ} 54.722^{\prime} \mathrm{N}, 141^{\circ} 02.743^{\prime} \mathrm{W} ; 4924\right.$ meters below sea level [mbsl]) (Fig. F1; Table T1) is located $\sim 120 \mathrm{~km}$ east and slightly south of IODP Site U1331, near the northwesternmost area drilled during the Pacific Equatorial Age Transect (PEAT) program (IODP Expedition 320/321). This site is situated on 50 Ma crust $\sim 750 \mathrm{~km}$ north of the Clipperton Fracture Zone, $\sim 380 \mathrm{~km}$ south of the Clarion Fracture Zone, and $\sim 270 \mathrm{~km}$ northeast of the nearest previously drilled Ocean Drilling Program (ODP) Site 1220 (56 Ma crust).

The Eocene was a time of extremely warm climates that reached a global temperature maximum (the Early Eocene Climatic Optimum [EECO]) near 52 Ma (Zachos et al., 2001; Shipboard Scientific Party, 2004). During that time, atmospheric $\mathrm{pCO}_{2}$ concentrations were elevated (Lowenstein and Demicco, 2007) and the early Eocene calcium carbonate compensation depth (CCD) was very shallow, estimated between 3200 and 3300 mbsl (Lyle, Wilson, Janecek, et al., 2002; Lyle et al., 2005; Rea and Lyle, 2005). From this temperature maximum there was a gradual climatic cooling through the Eocene to the Eocene/Oligocene boundary. Throughout the Eocene, the CCD lay near $3.2-3.3 \mathrm{~km}$ depth, albeit with potentially significant short-term fluctuations (Lyle et al., 2005). Thus, although recovering carbonate sediments from the equatorial region is a substantial challenge, it is not impossible if the depth of the East Pacific Rise lay near the global average of $2.7 \mathrm{~km}$.

During the early Eocene, a very shallow CCD and typical rapid tectonic plate subsidence of young crust near the shallow ridge crest conspired to make the time window during which carbonate is preserved very short ( 2 Ma) before each site sinks below the CCD (Rea and Lyle, 2005). Thus, although good records of pelagic carbonates during and just after the Paleocene/Eocene Thermal Maximum (PETM) were recovered at ODP Leg 199 sites (Lyle, Wilson, Janecek, et al., 2002; Raffi et al., 2005; Nuñes and Norris, 2006), the time period of the EECO (Zachos et al., 2001) and the shallowest CCD is not well sampled. In combination with Site U1331, which is located on crust with an age of $53 \mathrm{Ma}$, Site U1332 is located on crust with an expected age of $\sim 50$ Ma to intercept the interval between 50 and $48 \mathrm{Ma}$ in biogenic sediments above the CCD. Thus, Site U1332 forms the second oldest time slice component of Expedition 320/321. 
One of the common objectives of the PEAT program for all sites is to provide a limited depth transect for several Cenozoic key horizons, such as the EoceneOligocene transition (Coxall et al., 2005). For this objective, Site U1332 will form the second deepest paleodepth constraint, with an estimated crustal paleodepth of $\sim 4 \mathrm{~km}$ during the Eocene-Oligocene transition.

All Expedition 320/321 drill sites have in common the objective to improve and extend the extensive intercalibrated bio-, magneto-, chemo-, and astronomical stratigraphies for the Cenozoic (e.g., Shackleton et al., 2000; Pälike et al., 2006).

Site U1332 is located in abyssal hill topography with a general slope in topography to the north. The topography is dominated by small ridges that trend north-south and troughs of $\sim 5 \mathrm{~km}$ width (Fig. F1B). Bathymetric relief across the abyssal hills is 50-200 $\mathrm{m}$, and sediment cover is around $200 \mathrm{~ms}$ two-way traveltime (TWT), or $\sim 155 \mathrm{~m}$ using the velocity model developed by Busch et al. (2006).

The 48-channel stacked and migrated data (e.g., seismic Lines PEAT-2C-sl-1 and PEAT-2C-sl-6 in Pälike et al., 2008) (Lyle et al., 2006) reveal a region at the flanks of tilted ridges where older horizons are exposed nearer the surface. The site survey piston coring suggested that the surface sediments were formed at $\sim 20 \mathrm{Ma}$. Site survey seismic Line 6 (Fig. F2), on which Site U1332 is located, suggests $~ 160 \mathrm{~m}$ of sediment above basement. An interpretation of the site survey seismic data (Fig. F2) indicated that Site U1332 would penetrate seismic Reflectors P2 and P3 of Lyle, Wilson, Janecek, et al. (2002).

We positioned Site U1332 and the other PEAT sites to the south of the estimated paleoequatorial position at the target age in order to maximize the time that drill sites remain within the equatorial zone (i.e., $\pm 2^{\circ}$ of the Equator), to allow for some southward bias of the equatorial sediment mound relative to the hotspot frame of reference (Knappenberger, 2000), and to place the interval of maximum interest above the basal hydrothermal sediments. We located the site using the digital grid of seafloor age from Müller et al. (1997), heavily modified and improved with additional magnetic anomaly picks from Petronotis (1991), Petronotis et al. (1994), and Deep Sea Drilling Project (DSDP)/ODP basement ages, as well as the magnetostratigraphic data compiled by Cande et al. (1989) and Cande and Kent (1995). From the digital age grid, each point is backrotated in time to zero age, using the fixed-hotspot stagepoles from Koppers et al. (2001) and Engebretson et al. (1985) and the paleopole data from Sager and Pringle (1988). From the backtracked latitudes for each grid point we then obtained the paleoequator at the crustal age by contouring the paleolatitude on the original grid.

\section{Science summary}

Three holes were cored at Site U1332 $\left(11^{\circ} 54.722^{\prime} \mathrm{N}\right.$, $141^{\circ} 02.743^{\prime} \mathrm{W}$; $4924 \mathrm{mbsl}$ ) (Fig. F1; Table T1), which is the second northwesternmost site drilled during the PEAT program. At Site U1332, seafloor basalt is overlain by $\sim 150 \mathrm{~m}$ of pelagic sediment, containing radiolarian and nannofossil ooze with varying amounts of clay and zeolitic clay. The oldest sediment is of earliest middle Eocene age. Hole U1332A provided high-quality and high-recovery advanced piston corer (APC)-cored sediments from the mudline to $125.9 \mathrm{~m}$ core depth below seafloor (CSF) (Core 320-U1332A-14H), where we encountered porcellanite and chert and switched to the extended core barrel (XCB) cutting shoe. XCB coring advanced to $152.4 \mathrm{~m}$ drilling depth below seafloor (DSF) through a $\sim 10 \mathrm{~m}$ thick porcellanite-rich interval with reduced recovery. In the basal section, we recovered a short, $\sim 3.8 \mathrm{~m}$ long interval of barren very dense and stiff clay above basalt, $\sim 10 \mathrm{~m}$ shallower than predicted from the seismic profile, in Core 320-U1332A18X. Basement was reached at $152.4 \mathrm{~m}$ CSF. For detailed coring activities, see "Operations."

The uppermost $17.7 \mathrm{~m}$ consists of upper Miocene to Pleistocene-Pliocene clay, with varying amounts of radiolarians and zeolite minerals, overlying $\sim 130 \mathrm{~m}$ of Oligocene to middle Eocene nannofossil and radiolarian ooze with porcellanite deep in the section. A thin $\sim 3 \mathrm{~m}$ thick unit of middle Eocene zeolite clay bearing small porcellanite and chert nodules was recovered at the base of the sedimentary sequence, above basaltic basement. The sedimentary sequence at Site U1332 was divided into five major lithologies (Fig. F3).

The upper stratigraphy at Site U1332 has a strong resemblance to that of Site U1331 but without the sharp erosive contacts described at Site U1331. Several meters of white to beige-colored PleistocenePliocene clay (lithologic Unit I) overlie lower Miocene to lowermost Oligocene nannofossil ooze (Units II and III). There is a sharp lithologic change at the Eocene-Oligocene transition to alternating radiolarian ooze with nannofossils and nannofossil ooze (Subunit IVa). The lithology gradationally changes downhole into a dominance of radiolarian nannofossil ooze and nannofossil radiolarian ooze (Subunit IVb) and then into an interval of alternating radiolarian ooze, radiolarian nannofossil ooze, and nannofossil radiolarian ooze with porcellanite layers (Subunit IVc). Lithologic Unit V is composed of very dark grayish brown to black clay, very dark 
grayish brown to black zeolite clay, and chert. The sediments directly above basaltic basement are partially lithified. Basalt is designated as lithologic Unit VI, at 150 m CSF.

Carbonate content approaches $85 \mathrm{wt} \%$ in Unit III within the Oligocene nannofossil oozes and cycles between 0 and $40-60 \mathrm{wt} \%$ in the middle Eocene section (Unit IV) (Fig. F4). All major microfossil groups were found in sediments from Site U1332 and provide a consistent, coherent, and high-resolution biostratigraphic succession from basement to the top of Unit II. Calcareous nannofossils are abundant and moderately well preserved in the Oligocene and poor to moderately well preserved in the Miocene and Eocene. Most middle Eocene sediments commonly contain nannofossils; however, there are several barren intervals. Radiolarians are common to abundant throughout most of the section, apart from the lowermost sediment section above basalt. Radiolarians are well preserved in the Eocene and moderately well preserved in the Oligocene to lower Miocene section above. Radiolarian and nannofossil datums and zonal determinations agree, ranging from nannofossil Zones NP13/NP14 in the basal dark clay section ( 48.4-50.7 Ma) to Zone NN1 and radiolarian Zones RP13 above basement through RN1 (lowermost Miocene, $\sim 22.3 \mathrm{Ma}$ ) below the upper Pliocene-Pleistocene clay cover in Core 320-U1332A-3H (Fig. F4). Planktonic foraminifers are generally rare throughout the Oligocene but are absent in the Miocene and Eocene. Benthic foraminifers are present through most of the section but are rare in Miocene and Eocene sediments. They indicate lower bathyal to abyssal paleodepths. Sedimentation rates, as implied by biostratigraphic age determinations, vary throughout the section and are $\sim 5 \mathrm{~m} / \mathrm{m}$.y. in the Eocene section and $\sim 2.5 \mathrm{~m} / \mathrm{m}$.y. in the Oligocene, with two prominent hiatuses in the Miocene and between the Miocene and younger sediments. The presence of all major fossil groups as well as a detailed and well-resolved magnetostratigraphy will allow us to achieve one of the main PEAT objectives, to arrive at an integrated Cenozoic stratigraphy and age calibration (e.g., Pälike et al., 2006) for major parts of the Oligocene and Eocene.

Magnetostratigraphic studies as well as high-resolution biostratigraphy and stratigraphic correlation determined that a $4 \mathrm{~m}$ interval from the base of Core $320-\mathrm{U} 1332 \mathrm{~A}-8 \mathrm{H}$ was repeated in the top of Core $9 \mathrm{H}$, which comprises Chron C13n and the lowermost Oligocene. This repetition also occurs in Cores 320U1332B-8H and 9H and within Core 320-U1332C$9 \mathrm{H}$. The lithologic succession from the lower occurrence of Chron C13n downhole as well as from the upper occurrence of Chron C13n uphole both ap- pear complete and continuous; hence Site U1332 achieved the fortuitous feat of recovering the complete Eocene-Oligocene transition four times and the upper part of Chron C13n five times at a triplecored site. A likely explanation for this is the widespread occurrence of a slumped interval.

A full physical property program was run on cores from all three holes, including Whole-Round Multisensor Logger (WRMSL) measurements of magnetic susceptibility, bulk density, $P$-wave velocity, and noncontact resistivity, along with natural gamma radiation (NGR), followed by discrete measurements of color reflectance, index moisture and density properties, sound velocities, and thermal conductivity. Bulk density measurements show a marked increase in the carbonate-rich Oligocene section, as well as in carbonate-bearing horizons in the Eocene (carbonate accumulation event [CAE] cycles; Lyle et al., 2005). Magnetic susceptibility is variable throughout the section, allowing a detailed correlation among holes. NGR measurements are elevated by an order of magnitude in the surficial clay layer. Porosity values are generally high in the radiolarian-rich sediments $(85 \%)$ and decrease in the Oligocene and Eocene carbonate section, which also shows higher thermal conductivity values of $\sim 0.9$ to $1.2 \mathrm{~W} /(\mathrm{m} \cdot \mathrm{K})$, compared with $\sim 0.8 \mathrm{~W} /(\mathrm{m} \cdot \mathrm{K})$ in the radiolarian oozes and surficial clay.

Stratigraphic correlation allowed us to obtain a complete section to $\sim 125.5 \mathrm{~m} \mathrm{CSF}$ near the top of the porcellanite interval in Hole U1332A, equivalent to a composite depth of $\sim 140 \mathrm{~m}$ core composite depth below seafloor (CCSF-A) (see "Core composite depth scale" in the "Methods" chapter). The overall core expansion (growth factor), which is calculated by the ratio between the CCSF-A and CSF (formerly meters composite depth [mcd] and meters below seafloor [mbsf]) depth scales, is $\sim 10 \%$. The tops of APC cores were often affected by $\sim 3 \mathrm{~m}$ heave that occurred during operations at Site U1332. Stratigraphic correlation supports the biostratigraphic, paleomagnetic, and sedimentologic description of a repeated sequence, possibly due to slumping, spanning the Eocene-Oligocene transition.

A full range of paleomagnetic analyses was conducted on cores and samples from Site U1332 and resulted in a well-resolved magnetostratigraphy. Shipboard analyses suggest that a useful magnetic signal is preserved in all APC-cored intervals and that it was possible to remove the drilling-induced steep inclination overprint by alternating-field demagnetization. Comparison of biostratigraphic data and changes in magnetic paleodeclinations suggests the recovery of magnetic reversals Chrons C1n/C1r.1r to C2An.3n/C2Ar above a hiatus and then a continu- 
ous sequence of magnetic reversals from Chrons C5En/C5Er (18.52 Ma) in the Miocene at $\sim 12.95 \mathrm{~m}$ CSF (interval 320-U1332C-2H-4, $95 \mathrm{~cm}$ ) to C19r/ C20n (42.54 Ma) at interval 320-U1332A-14H-5, 80 $\mathrm{cm}$. Magnetostratigraphic interpretation supports the presence of a slump through multiple recovery (five times) of parts of Chron C13n in a triple-cored sequence. Paleomagnetic directions from discrete samples agree well with those from split-core results.

A standard shipboard suite of geochemical analyses of pore water and organic and inorganic sediment properties was conducted on samples from Site U1332. Alkalinity values increase from $\sim 2.2$ to 3.4 $\mathrm{mM}$ downsection, and $\mathrm{Sr}^{2+}$ increases from $\sim 80$ to $\sim 110 \mu \mathrm{M} . \mathrm{H}_{4} \mathrm{SiO}_{4}$ remains relatively stable between 400 and $600 \mu \mathrm{M}$ above $90 \mathrm{~m}$ depth in the Oligocene nannofossil oozes but increases to $800-1000 \mu \mathrm{M}$ in the Eocene silica-rich radiolarian oozes. Carbonate coulometry yielded carbonate contents of $\sim 85 \mathrm{wt} \%$ in the Oligocene nannofossil ooze and horizons with up to $60 \mathrm{wt} \% \mathrm{CaCO}_{3}$ in the middle Eocene radiolarian-rich oozes. Total organic carbon (TOC) contents were measured both by difference between total carbon (TC) and total inorganic carbon (IC) as well as by using an acidification method. Using the acidification method, TOC values were $<0.3 \mathrm{wt} \%$ for all measured samples. The top $\sim 5 \mathrm{~m}$ shows values of $0.18-0.17$ wt $\%$ TOC. Between $\sim 40$ and $70 \mathrm{~m}$ CSF the measurements indicate TOC below the detection limit of $0.03 \mathrm{wt} \%$, and downhole from this, values are generally low. We conducted a high-resolution Rhizon pore water experiment across an alkalinity trough around $40 \mathrm{~m} \mathrm{CSF}$, which highlighted comparisons between squeezed and Rhizon-sampled pore waters. Additional ephemeral samples were taken for shore-based microbiology and permeability studies.

Wireline logging provided valuable information to constrain the interval of porcellanite and chert formation within the borehole. Downhole NGR, density, and magnetic susceptibility logs provide important constraints on the poorly recovered lithologies below and between porcellanite-bearing horizons. The logging data document the presence of two thin porcellanite horizons at $\sim 126$ and $130 \mathrm{~m}$ wireline log depth below seafloor (WSF) and an $\sim 14 \mathrm{~m}$ thick interval of increased magnetic susceptibility, reduced conductivity, and enhanced density and photoelectric factor that appears to be the dark and dense clays and zeolitic clays above basement, rather than carbonate. Integration with the seismic data will allow further improvements with the regional seismic interpretations. Data from Site U1332 indicate that the top of seismic Horizon P2 (Lyle et al., 2002) correlates with the top of the porcellanite section, just as it did for Site U1331. No Formation MicroScanner (FMS) data were collected, as it was not possible to retrieve the "paleo-" triple-combination (triple combo) tool string back into the bottom-hole assembly (BHA). Eight downhole temperature measurements were conducted in Holes U1332B and U1332C with the advanced piston corer temperature (APCT3) tool. Three of these yielded good data; the other measurements were impaired by strong, sometimes $>3 \mathrm{~m}$ heave during operations in Hole U1332B.

Downhole temperature measurements, when combined with the thermal conductivity values obtained from the cores, indicate that Site U1332 has a heat flow of $70.7 \mathrm{~mW} / \mathrm{m}^{2}$ and a thermal gradient of $75.0^{\circ} \mathrm{C} / \mathrm{km}$. This is significantly higher than the values obtained for Site U1331 but comparable to values obtained for Sites 1218 and 1219.

\section{Highlights \\ Shallow early Eocene CCD}

Coring at Site U1332 was designed to capture a very short period of time ( 2 m.y.) at $\sim 50$ Ma during which this site was thought to be located above the very shallow Eocene CCD $(\sim 3.3 \mathrm{~km})$ (Lyle, Wilson, Janecek, et al., 2002; Rea and Lyle, 2005) just after the EECO (Zachos et al., 2001). Unlike Site U1331, at Site U1332 we cored a $\sim 10 \mathrm{~m}$ thick section of dense and dark brown clays, zeolite clays, and chert above basement, although relatively common nannofossils were present in the lowermost samples from Hole U1332B. This finding will provide important new constraints on the depth of the CCD at $\sim 48-50 \mathrm{Ma}$ at the paleoequator, indicating that the CCD was shallower than previously thought.

\section{Stratigraphic integration}

One of the primary objectives of the PEAT science program is the integration of different stratigraphic methodologies and tools. Site U1332 contains all major fossil groups (nannofossils, radiolarians, foraminifers, and diatoms), as well as an excellent magnetostratigraphy and composite depth correlation, which can be tied to nearby Leg 199 sites (e.g., Site 1220) by way of physical property variations. The possibility of a cycle-by-cycle match between Sites U1332 and 1220 has been demonstrated using magnetic susceptibility and bulk density data, providing additional stratigraphic tie points and a verification of the completeness of the stratigraphic section on a regional scale. Thus, Site U1332 will help us to achieve an integrated stratigraphy for the Cenozoic Pacific Ocean, ranging from the Miocene to the middle Eocene. 


\section{Eocene-Oligocene and Oligocene-Miocene transitions and depth transects}

Site U1332 forms the second oldest and deepest component of the PEAT depth transect, which will allow the study of critical intervals (such as the Eocene-Oligocene transition; see Coxall et al., 2005) and variations of the equatorial CCD. Site U1332 is estimated to have been $\sim 4 \mathrm{~km}$ deep during the Eocene-Oligocene transition, $\sim 1 \mathrm{~km}$ shallower than today and $200 \mathrm{~m}$ shallower at that time than Site U1331. Sediments rapidly change from radiolarian ooze below the transition into nannofossil oozes above, and unlike Site U1331, Site U1332 also contains carbonate-bearing sediments across the Oligocene-Miocene transition. For the Eocene-Oligocene transition, Site U1332 will provide a tie point for calcium carbonate burial at $\sim 4^{\circ}$ to $5^{\circ}$ paleolatitude.

\section{Variations in the CCD}

Site U1332 has provided important constraints for variations and depth of the CCD from the early Eocene to the late Miocene. This site shows increased carbonate content and much increased mass accumulation rates approaching $200 \mathrm{mg} \mathrm{CaCO}_{3} / \mathrm{cm}^{2} / \mathrm{k}$.y. around the middle of Chron C18r to the base of Chron C19r during the middle Eocene, which can be correlated to an interval of enhanced carbonate burial that was previously documented by Lyle et al. (2005) in Leg 199 cores. The early Oligocene high $\mathrm{CaCO}_{3}$ concentrations decrease significantly in sediments younger than $\sim 27 \mathrm{Ma}$. By $\sim 22 \mathrm{Ma}$, in the early Miocene, carbonate was no longer preserved. This is presumably related to Site U1332 sinking below the prevalent CCD and coincides with a CCD shoaling event between $\sim 20$ and 15.5 Ma described by Lyle (2003).

\section{Formation of porcellanite and chert}

Together with Site U1331, Site U1332 provides important new information on the formation of porcellanite and chert. Coring has shown that the top of the porcellanite-rich interval is mapped by seismic Horizon P2 (Lyle et al., 2002). In lithologic Subunit IVc, layers and pebbles of very dark brown partially to well-lithified mudstones, often layered or even laminated, are observed within alternating sequences of nannofossil ooze and radiolarian ooze of late to late middle Eocene age. In hand specimen, the partially lithified mudstones are particularly rich in clay and show evidence of partial secondary silicification. Pieces of porcellanite contain clay minerals, microcrystalline quartz, opaques, and calcite, as well as biogenic shells and fragments from radiolarians and foraminifers. Sediments from Sites U1331 and
U1332 appear to document the silicification process in clay-rich horizons near basement, which will likely extend the findings of Moore (2008).

\section{Age transect of seafloor basalt}

At Site U1332 we recovered what appear to be fresh fragments of seafloor basalt, aged between 49 and 50 Ma as estimated from biostratigraphic results. This material will, when combined with other PEAT basalt samples, provide important sample material for the study of seawater alteration of basalt.

\section{Operations}

Unless otherwise noted, times are local ship time, which was Hawaii Standard Time (UTC - 10 h) for Site U1332.

\section{Transit to Site U1332}

Following completion of Site U1331, we started heading east to Site U1332. The vessel made slow progress into a $20 \mathrm{kt}$ wind and against a strong current with moderate pitching and rolling into a $6-8 \mathrm{ft}$ swell with spray occasionally over the bow. This reduced the average speed of the $66.1 \mathrm{nmi}$ voyage to Site U1332 to $7.1 \mathrm{kt}$.

\section{Site U1332}

\section{Hole U1332A}

After the $9.25 \mathrm{~h}$ transit, we began positioning over the site at $1445 \mathrm{~h}$ on 22 March 2009. We assembled the BHA, and spaceout of the colletted delivery system was verified. Because the precision depth recorder (PDR) was still not working, it was necessary for the driller to carefully lower the bit and tag the seafloor to verify the exact depth. As the driller was preparing to spud the hole, the display that indicates coring line position relative to the rig floor failed. Because it is imperative for the core winch operator to know where the coring line is at all times, operations had to be suspended for $3 \mathrm{~h}$ while the defective unit was replaced.

Hole U1332A was spudded with the APC at $1050 \mathrm{~h}$ on 23 March. The water depth calculated from the recovery of the first core was established as $4935.1 \mathrm{~m}$ drilling depth below rig floor (DRF) (4923.9 mbsl) (Table T1). APC Cores $1 \mathrm{H}$ through $14 \mathrm{H}$ penetrated from 0 to $125.9 \mathrm{~m}$ DSF, and we recovered $131.9 \mathrm{~m}$ (104\%) (Table T1). All piston cores were oriented with the FlexIt tool. Because of the potential presence of chert horizons, no downhole temperature measurements were attempted in Hole U1332A. Core $14 \mathrm{H}$ required $70,000 \mathrm{lb}$ of overpull to extract 
the core barrel from the sediment, after which we switched to XCB coring.

We recovered $13.8 \mathrm{~m} \mathrm{(51 \% )} \mathrm{in} \mathrm{XCB} \mathrm{Cores} \mathrm{15X}$ through 18X (125.9 to $152.4 \mathrm{~m} \mathrm{DSF})$. Coring was terminated when Core $18 \mathrm{X}$ was recovered with a piece of basaltic basement. Hole U1332A was cored to $152.4 \mathrm{~m}$, and we recovered $145.6 \mathrm{~m}$ (96\%).

After coring was finished, we prepared the hole for logging by flushing it with $65 \mathrm{bbl}$ of attapulgite mud and then dropping a go-devil to open the lockable float valve (LFV). We then displaced the hole with 80 bbl of attapulgite mud and raised the bit to $78 \mathrm{~m}$ DSF.

We then deployed a tool string consisting of the magnetic susceptibility, GRA density, and NGR tools. This tool string acquired good downhole logs over the entire open hole interval. Unfortunately, the tool string parted from the logging wireline when attempting to recover the tool and the tool string was lost in the hole.

We spent $\sim 18 \mathrm{~h}$ conducting three unsuccessful coring line fishing attempts to recover the logging tool string. After acknowledging that spending more time fishing for the tool string would not be productive, the decision was made to seal Hole U1332A with 15 bbl of cement (from 125 to 90 m DSF) above the lost logging tool. Deploying the cement had to be delayed for $4 \mathrm{~h}$ while the cement pumps were repaired.

After the cementing operations were completed, the bit was pulled free of the seafloor at $0800 \mathrm{~h}$ on 26 March and the vessel was offset $20 \mathrm{~m}$ north of Hole U1332A. Before coring could resume, the drill string was flushed with seawater to remove any cement from the tubulars and bit nozzles.

\section{Hole U1332B}

Hole U1332B was spudded at $1230 \mathrm{~h}$ on 26 March. We started coring Hole U1332B with the bit offset 5 $\mathrm{m}$ deeper than the seafloor depth established for Hole U1332A but only penetrated to $2.1 \mathrm{~m}$ CSF below the mudline. We recovered $118.4 \mathrm{~m}(107 \%)$ in APC Cores $1 \mathrm{H}$ through $13 \mathrm{H}$ (0-110.1 m DSF). In an attempt to maintain an offset with the first hole, there were short advances with Cores $3 \mathrm{H}(8.0 \mathrm{~m})$ and $11 \mathrm{H}(5.0 \mathrm{~m})$. The APCT-3 was deployed while taking cores at six different depths: 11.6, 19.6, 38.6, 57.6, 76.6, and $100.6 \mathrm{~m}$ DSF (Cores $2 \mathrm{H}, 3 \mathrm{H}, 5 \mathrm{H}, 7 \mathrm{H}, 9 \mathrm{H}$, and $12 \mathrm{H}$, respectively). Nonmagnetic core barrels were used on all cores except $13 \mathrm{H}$.

We then switched to the XCB and took Cores $14 \mathrm{X}$ to 18X from 110.1 to $148.6 \mathrm{~m}$ DSF and recovered 23.4 $\mathrm{m}(61 \%)$. Coring was terminated when we recovered $\sim 2.4 \mathrm{~m}$ of dark brown sediment above several small pieces of basalt in Core 18X.
In Hole U1332B we cored a total of $148.6 \mathrm{~m}$ and recovered $141.8 \mathrm{~m}(95 \%)$. The drill string was pulled out of the hole and the bit cleared the seafloor at $2230 \mathrm{~h}$ on 27 March.

\section{Hole U1332C}

Hole U1331C was designed to provide stratigraphic overlap and confirm stratigraphic correlations with Holes U1332A and U1332B. After the vessel was offset $30 \mathrm{~m}$ north of Hole U1332B, Hole U1332C was spudded at $0105 \mathrm{~h}$ on $28 \mathrm{March}$. The seafloor depth calculated from the recovery of the first core was 4934.0 m DRF (4922.8 mbsl). Piston coring then routinely proceeded to $85.0 \mathrm{~m}$ DSF, during which the advances of Cores $6 \mathrm{H} \mathrm{(4.0} \mathrm{m} \mathrm{advance)} \mathrm{and} 8 \mathrm{H}(7.0 \mathrm{~m}$ advance) were adjusted to maintain overlap with previous holes. At $\sim 1330 \mathrm{~h}$ on $28 \mathrm{March}$, while retrieving Core $10 \mathrm{H}$, an electrical transient attributed to the rotating condenser caused two of the three main generators to trip off the main bus and resulted in a load shedding sequence to various systems on the vessel, which included loss of control voltage to all Thyrig bays for $\sim 10 \mathrm{~min}$. The consequence of the loss of Thyrig control voltage was a short-term loss of power to thrusters, propulsion, and drilling motors. During this short event, the dynamic positioning (DP) 3\% watch circle (percentage of water depth or $\sim 150 \mathrm{~m}$ off the hole) was not exceeded. The main breakers quickly reset and power was restored to all main systems by $1341 \mathrm{~h}$. We thought the switching circuit for removing the rotating condenser from the main bus was defective.

Because of the power loss, the coring line parted while attempting to recover Core $10 \mathrm{H}$, and we had to make two fishing trips with the coring line to recover the sinker bars and the full core barrel. Unfortunately, this APC core was near the Eocene/Oligocene boundary and was very disturbed. APC coring continued to $113.5 \mathrm{~m}$ DSF, where coring was switched to the XCB. All the APC cores were obtained with nonmagnetic core barrels and with the FlexIt core orientation tool except Core $13 \mathrm{H}$, for which we used a standard steel core barrel. APCT-3 formation temperature measurements were made at $36.0 \mathrm{~m}$ DSF (Core 4H) and $75.5 \mathrm{~m}$ DSF (Core 9H). APC Cores $1 \mathrm{H}$ through $13 \mathrm{H}$ extended from 0 to $113.5 \mathrm{~m}$ DSF, and we recovered $122.04 \mathrm{~m}$ (108\%). XCB Cores 14X through 18X extended from 113.5 to $155.5 \mathrm{~m}$ DSF, where basement was encountered, and we recovered $26.02 \mathrm{~m} \mathrm{(62 \% ).} \mathrm{The} \mathrm{total} \mathrm{core} \mathrm{interval}$ with both coring systems was $155.5 \mathrm{~m}$ with $148.1 \mathrm{~m}$ recovered (95\%).

Once the final core was on deck, we started recovering the drill string. The seafloor beacon was successfully recovered on deck at $1202 \mathrm{~h}$ on 29 March. At 
$1930 \mathrm{~h}$ on 29 March, the drilling equipment had been secured and we departed for Site U1333.

\section{Lithostratigraphy}

Drilling at Site U1332 recovered a $150.4 \mathrm{~m}$ thick section of pelagic sediments overlying seafloor basalt. The uppermost $17.7 \mathrm{~m}$ of the section is a late Miocene to Pliocene-Pleistocene clay with varying amounts of radiolarians and zeolite minerals ( $\sim 6$ to 22 Ma based on radiolarians and magnetostratigraphy). These sediments are underlain by $\sim 130 \mathrm{~m}$ of Oligocene to middle Eocene nannofossil and radiolarian ooze with porcellanite deep in the section. A thin ( $3 \mathrm{~m}$ thick) unit of middle Eocene zeolite clay bearing small chert nodules was recovered at the base of the sedimentary sequence above basement basalt.

The sedimentary sequence at Site U1332 is divided into five major lithologic units, with one of these units further divided into three subunits (Fig. F3; Table T2). Unit and subunit boundaries are defined by differences in lithology, measured physical properties, and calcium carbonate $\left(\mathrm{CaCO}_{3}\right)$ content. Lithologic differences, based on both visual core descriptions and smear slide and thin section analysis, are primarily attributable to varying distributions of biogenic components (e.g., nannofossils and radiolarians) and clay-sized lithogenic material, as well as the presence of porcellanite (Table T2; Figs. F3, F5, F6, F7; see "Site U1332 thin sections" and "Site U1332 smear slides" in "Core descriptions"). Lithologic descriptions are primarily based on sediments recovered in Hole U1332A, supplemented with observations from Holes U1332B and U1332C.

\section{Unit I}

Intervals: $320-1332 \mathrm{~A}-1 \mathrm{H}-1,0 \mathrm{~cm}$, through $3 \mathrm{H}-3$, $130 \mathrm{~cm} ; 320-\mathrm{U} 1332 \mathrm{~B}-1 \mathrm{H}-1,0 \mathrm{~cm}$, through $3 \mathrm{H}-4$, $150 \mathrm{~cm} ; 320-\mathrm{U} 1332 \mathrm{C}-1 \mathrm{H}-1,0 \mathrm{~cm}$, through $3 \mathrm{H}-1$, $70 \mathrm{~cm}$

Depths: Hole U1332A = 0-17.7 m CSF; Hole $\mathrm{U} 1332 \mathrm{~B}=0-17.6 \mathrm{~m}$ CSF; Hole U1332C $=0-17.7$ $\mathrm{m}$

Age: Miocene-Pliocene-Pleistocene

Lithology: clay and radiolarian clay

The major lithology in Unit I is light yellowish brown (10YR 6/4) to very dark brown (10YR 3/2) to dark gray (10YR 4/1) clay. The light yellowish brown clay with radiolarians occurs in the uppermost $\sim 8 \mathrm{~m}$ of the sedimentary section (in Hole U1332A), overlying the darker zeolite clay. The downhole transition from radiolarian clay to zeolite clay is characterized by a change to darker color and shifts to higher mag- netic susceptibility but lower gamma ray attenuation (GRA) bulk densities and L* (lightness) (Fig. F3; see "Physical properties" for discussion of additional reflectance parameters $\mathrm{a}^{*}$ and $\left.\mathrm{b}^{*}\right)$. $\mathrm{CaCO}_{3}$ contents are near zero throughout Unit I. The contact with underlying Unit II takes place over a $\sim 5 \mathrm{~cm}$ thickinterval.

\section{Unit II}

Intervals: $320-\mathrm{U} 1332 \mathrm{~A}-3 \mathrm{H}-3,130 \mathrm{~cm}$, through $5 \mathrm{H}-$ $1,150 \mathrm{~cm} ; 320-\mathrm{U} 1332 \mathrm{~B}-3 \mathrm{H}-4,150 \mathrm{~cm}$, through $5 \mathrm{H}-1,150 \mathrm{~cm} ; 320-\mathrm{U} 1332 \mathrm{C}-3 \mathrm{H}-1,70 \mathrm{~cm}$, through $4 \mathrm{H}-7,30 \mathrm{~cm}$

Depths: Hole U1332A = 17.7-33.9 m CSF; Hole $\mathrm{U} 1332 \mathrm{~B}=17.6-30.6 \mathrm{~m}$ CSF; Hole U1332C $=$ $17.7-35.8 \mathrm{~m}$

Age: early Miocene to late Oligocene

Lithology: alternations of clayey radiolarian ooze and nannofossil ooze

The dominant lithologies in Unit II are dark brown (10YR 3/2) to very dark grayish brown (10YR 3/2) clayey radiolarian ooze, yellowish brown (10YR 5/4) to pale brown (10YR 6/3) nannofossil ooze, and dark brown (10YR 3/3) radiolarian ooze. Bioturbation is generally minor to moderate in these sediments. Within the major lithologies, nannofossil ooze sometimes occurs with radiolarians and sometimes occurs with radiolarians and clay as minor lithologic components, whereas radiolarian ooze occurs with clay as a minor lithologic component. Alternating sequences of nannofossil ooze and radiolarian ooze occur at decimeter to meter scales. The contact with underlying Unit III takes place over a $5 \mathrm{~cm}$ interval. Unit II sediments have $\mathrm{CaCO}_{3}$ contents (typically $\leq 40 \%$ ) that are lower than those of the underlying Unit III, whereas magnetic susceptibility, GRA bulk densities, and $L^{*}$ all show systematically lower values in Unit II than in Unit I (Fig. F3; see "Geochemistry").

\section{Unit III}

Intervals: 320-U1332A-5H-2, $0 \mathrm{~cm}$, through 9H-4, $124 \mathrm{~cm} ; 320-\mathrm{U} 1332 \mathrm{~B}-5 \mathrm{H}-2,0 \mathrm{~cm}$, through $9 \mathrm{H}-6$, $50 \mathrm{~cm}$; 320-U1331B-4H-7, $30 \mathrm{~cm}$, through $10 \mathrm{H}-$ $1,41 \mathrm{~cm}$

Depths: Hole U1332A = 33.9-76.14 m CSF; Hole $\mathrm{U} 1332 \mathrm{~B}=30.6-75.1 \mathrm{~m}$; Hole U1332C 35.8$75.91 \mathrm{~m} \mathrm{CSF}$

Age: early Oligocene

Lithology: nannofossil ooze, nannofossil ooze with radiolarians, and radiolarian nannofossil ooze

The dominant lithology in Unit III is white (10YR 8/ 1) to brown (10YR 5/3) nannofossil ooze, but brown 
radiolarian nannofossil ooze is also a major lithology in this unit. Within the major lithologies, nannofossil ooze occurs with diatoms as a minor lithologic component. Bioturbation intensity is minor to intense in these sediments. Baseline values of magnetic susceptibility are low with large-amplitude variability in comparison to the overlying units. Data series for GRA bulk density, $\mathrm{L}^{*}$, and $\mathrm{CaCO}_{3}$ all show high baseline values with large-amplitude variability in comparison to the overlying units (see Fig. F3). The contact with underlying Unit IV is marked by a light to dark color change over a $20 \mathrm{~cm}$ bioturbated boundary.

\section{Unit IV}

Intervals: $320-\mathrm{U} 1332 \mathrm{~A}-9 \mathrm{H}-4,124 \mathrm{~cm}$, through at least 16X-CC, $42 \mathrm{~cm}$; 320-U1332B-9H-6, $50 \mathrm{~cm}$, through at least $17 \mathrm{X}-\mathrm{CC}, 40 \mathrm{~cm} ; 320-\mathrm{U} 1332 \mathrm{C}$ $10 \mathrm{H}-1,41 \mathrm{~cm}$, through at least $17 \mathrm{X}-2,7 \mathrm{~cm}$

Depths: Hole U1332A = 76.14-138.29 m CSF; Hole $\mathrm{U} 1332 \mathrm{~B}=75.1-135.08 \mathrm{~m}$ CSF; Hole U1332C = 75.91-138.77 m CSF

Age: middle to late Eocene

Lithology: clayey radiolarian ooze, radiolarian ooze, radiolarian nannofossil ooze, nannofossil radiolarian ooze, nannofossil ooze, and porcellanite

Unit IV is distinguished from Unit III by the dominance of radiolarian ooze. The major lithologies in Unit IV are dark brown (10YR 3/3) to brown (10YR 5/ $3)$ radiolarian ooze, very dark grayish brown (10YR $3 / 2$ ) to brown (10YR 4/3) clayey radiolarian ooze, dark yellowish brown (10YR 3/4) to light gray (10YR $7 / 2$ ) nannofossil radiolarian ooze, brown (10YR 5/3) to light gray (10YR 7/2) radiolarian nannofossil ooze, and brown (10YR 5/3) nannofossil ooze. Downhole lithologic changes within Unit IV allow division into three subunits based on the significance of nannofossil ooze, radiolarian nannofossil ooze, and porcellanite as secondary major lithologies and the downhole profile of $\mathrm{CaCO}_{3}$ (Fig. F3; see "Geochemistry").

\section{Subunit IVa}

Intervals: 320-U1332A-9H-4, $124 \mathrm{~cm}$, through $13 \mathrm{H}-1,20 \mathrm{~cm} ; 320-\mathrm{U} 1332 \mathrm{~B}-9 \mathrm{H}-7,0 \mathrm{~cm}$, through $13 \mathrm{H}-5,120 \mathrm{~cm} ; 320-\mathrm{U} 1332 \mathrm{C}-10 \mathrm{H}-1,41 \mathrm{~cm}$, through $13 \mathrm{H}-2,150 \mathrm{~cm}$

Depths: Hole U1332A = 76.14-108.6 m CSF; Hole $\mathrm{U} 1332 \mathrm{~B}=75.1-107.8 \mathrm{~m}$ CSF; Hole U1332C = 75.91-107.0 m CSF

Age: middle to late Eocene

Lithology: alternations of nannofossil ooze, radiolarian nannofossil ooze, radiolarian ooze, and clayey radiolarian ooze
Subunit IVa is distinguished from Subunits IVb and IVc based on the dominance of radiolarian ooze and absence of porcellanite. The major lithologies in Subunit IVa are dark brown (10YR 3/3) to brown (10YR $5 / 3$ ) radiolarian ooze, dark brown (10YR 3/3) clayey radiolarian ooze, and brown (10YR 4/3) to pale brown (10YR 6/3) radiolarian nannofossil ooze. Within the major lithologies, radiolarian ooze occurs with either clay or nannofossils. Bioturbation is generally minor to moderate in these sediments. GRA bulk density, $\mathrm{L}^{*}$, and $\mathrm{CaCO}_{3}$ content all decrease downhole across the Unit III/Subunit IVa boundary and maintain relatively low values throughout (Fig. F3). Magnetic susceptibility is generally higher in the upper portion of Subunit IVa than in Unit III and decreases toward the boundary with Subunit IVb. The contact with underlying Subunit IVb takes place over a $5 \mathrm{~cm}$ interval.

\section{Subunit IVb}

Intervals: 320-U1332A-13H-1, $20 \mathrm{~cm}$, through $14 \mathrm{H}-1,150 \mathrm{~cm}$; 320-U1332B-13H-5, $120 \mathrm{~cm}$, through $15 \mathrm{H}-4,40 \mathrm{~cm}$; 320-U1332C-13H-3, 0 $\mathrm{cm}$, through $15 \mathrm{H}-2,50 \mathrm{~cm}$

Depths: Hole U1332A = 108.6-119.4 m CSF; Hole $\mathrm{U} 1332 \mathrm{~B}=107.8-121.0 \mathrm{~m}$ CSF; Hole U1332C = 107.0-120 m CSF

Age: middle Eocene

Lithology: alternations of nannofossil ooze, radiolarian nannofossil ooze, and nannofossil radiolarian ooze

Subunit IVb is distinguished from Subunits IVa and IVc based on the dominance of radiolarian nannofossil and nannofossil oozes and absence of porcellenite. The major lithologies in Subunit IVb are brown (10YR 5/3) nannofossil ooze, dark yellowish brown (10YR 4/4) radiolarian nannofossil ooze, and dark brown (10YR 3/3) nannofossil radiolarian ooze. Within the major lithologies, nannofossil ooze occurs with radiolarians as a minor component and nannofossil radiolarian ooze occurs with clay as a minor component. Alternations of nannofossil ooze and radiolarian nannofossil ooze in Subunit IVb occur at decimeter to meter scales. Bioturbation is generally minor to moderate in these sediments.

\section{Subunit IVc}

Intervals: $320-\mathrm{U} 1332 \mathrm{~A}-14 \mathrm{H}-2,0 \mathrm{~cm}$, through at least 16X-CC, $42 \mathrm{~cm}$ (base not recovered); 320$\mathrm{U} 1332 \mathrm{~B}-15 \mathrm{H}-4,40 \mathrm{~cm}$, through at least $17 \mathrm{X}-\mathrm{CC}$, $40 \mathrm{~cm}$ (base not recovered); 320-U1332C-15H-2, $50 \mathrm{~cm}$, through $17 \mathrm{X}-2,7 \mathrm{~cm}$

Depths: Hole U1332A $=119.4$ to at least $138.39 \mathrm{~m}$ CSF; Hole U1332B $=121.0$ to at least $135.08 \mathrm{~m}$ CSF; Hole U1332C $=121.0$ to least $138.77 \mathrm{~m} \mathrm{CSF}$ 
Age: middle Eocene

Lithology: alternations of radiolarian nannofossil, radiolarian ooze, and nannofossil radiolarian ooze with porcellanite layers or nodules

Subunit IVc is distinguished from Subunits IVa and $\mathrm{IVb}$ based on the presence of porcellanite. The major lithologies in Subunit IVc are dark brown (10YR 3/3) to dark yellowish brown (10YR 4/4) radiolarian ooze, brown (10YR 5/3) radiolarian nannofossil ooze, very dark grayish brown (10YR 3/2) clayey radiolarian ooze, and porcellanite. Within the major lithologies, radiolarian ooze occurs with clay as well as with clay and nannofossils as minor components. Nannofossil radiolarian ooze is a minor lithology in Hole U1332A. Alternations of nannofossil radiolarian ooze with radiolarian nannofossil ooze and of radiolarian ooze with clay and radiolarian ooze with clay and nannofossils occur on decimeter to meter scales in Subunit IVc. Bioturbation is generally minor to moderate in these sediments. Magnetic susceptibility, GRA bulk density, and $\mathrm{L}^{*}$ are comparatively low in Subunit IVc at Site U1332. In thin section, porcellanite layers and nodules contain flat flakes of clay minerals, radiolarians, nannofossils, and foraminifers. Radiolarian and foraminifer tests are partially replaced with microcrystalline quartz.

\section{Unit V}

Intervals: At least 320-U1332A-17X-1, $0 \mathrm{~cm}$ (top not recovered), through $17 \mathrm{X}-\mathrm{CC}, 3 \mathrm{~cm}$; $320-$ U1332B-18X-1, $0 \mathrm{~cm}$, through at least $18 \mathrm{X}-\mathrm{CC}$, $16 \mathrm{~cm}$ (base not recovered); 320-U1332C-17X-2, $7 \mathrm{~cm}$, through at least 18X-CC, $46 \mathrm{~cm}$ (base not recovered)

Depths: Hole U1332A $=144.50$ to at least $148.15 \mathrm{~m}$ CSF; Hole U1332B $=143.90$ to at least $146.09 \mathrm{~m}$ CSF; Hole U1332C $=138.77$ to at least $147.36 \mathrm{~m}$ CSF

Age: middle Eocene

Lithology: clay, zeolite clay, and chert

The major lithologies in Unit $\mathrm{V}$ are very dark grayish brown (10YR 3/2) to black (10YR 2/1) clay, very dark grayish brown (10YR 3/2) to black (10YR 2/1) zeolite clay, and chert. Sediments at the very base of the sedimentary section directly overlying basalt are partially lithified with nonvisible bioturbation.

\section{Unit VI}

Intervals: $320-\mathrm{U} 1332 \mathrm{~A}-17 \mathrm{X}-\mathrm{CC}, 3 \mathrm{~cm}$, to at least $18 \mathrm{X}-\mathrm{CC}, 52 \mathrm{~cm}$; 320-U1332B-18X-CC, $16 \mathrm{~cm}$, to at least 18X-CC, $34 \mathrm{~cm}$; 320-U1332C-18X-CC, $46 \mathrm{~cm}$, to at least $18 \mathrm{X}-\mathrm{CC}, 62 \mathrm{~cm}$

Depths: Hole U1332A = 148.15-150.56 m CSF; Hole U1332B = 146.09-146.27 m CSF; Hole $\mathrm{U} 1332 \mathrm{C}=147.36-147.52 \mathrm{~m}$
Small broken basalt pieces were recovered at the base of each hole at Site U1332. Thin section analysis indicates a highly altered phyric basalt with sparse plagioclase (Sample 320-U1332A-18X-CC (Piece 3A, $16-19 \mathrm{~cm}$ ) (see "Site U1332 thin sections" in "Core descriptions"). Fragments of glass in the groundmass are highly altered and show spherulitic texture, and ferromagnesian minerals (mainly clinopyroxene) are replaced with chlorite. Sample 320-U1332A-18X-CC (Piece 2A, 12-16 cm) is a partly altered phyric basalt with sparse plagioclase. Glass and clinopyroxene in the groundmass are preserved in a chilled margin. Calcite veins are observed in both pieces and show a distinct radiaxial fabric.

\section{Sediments across the Eocene-Oligocene transition}

An Eocene-Oligocene transition was recovered in two of the three holes at Site U1332 (Holes U1332A and U1332B) (Fig. F8). The transition was not recovered in Hole U1332C because of core disturbance associated with a shipboard power outage (see "Operations"). The Eocene/Oligocene boundary is formally defined by the extinction of the planktonic foraminifer genus Hantkenina but cannot be identified at Site U1332 because of poor preservation of planktonic foraminifers (see "Biostratigraphy"). Radiolarian and nannofossil bio- and magnetostratigraphy provide excellent age control, indicating that the Eocene/Oligocene boundary falls somewhere between the base of Chron 13n and the Biozone RP20/RP19 boundary (within Cores 320-U1332A-9H, 320U1332B-9H, and 10H). The lithostratigraphy of the Eocene-Oligocene transition at Site U1332 is well captured in both of these holes and consists of a downhole change from light gray (10YR 7/2) and very pale brown (10YR 7/3) nannofossil ooze with diatoms to very pale brown (10YR 8/2) nannofossil ooze to brown (10YR 4/3) radiolarian nannofossil ooze and dark yellow brown (10YR 3/4) radiolarian ooze with clay (Fig. F8). The transition from pale nannofossil ooze to radiolarian ooze is comparatively abrupt ( $1 \mathrm{~m}$ interval) and defines the Unit III/ Unit IV boundary. An associated pronounced downhole increase occurs in magnetic susceptibility, together with pronounced downhole decease in GRA bulk density, $\mathrm{L}^{*}$, and $\mathrm{CaCO}_{3}$ content (Figs. F3, F8). These lithostratigraphic results for the Eocene-Oligocene transition at Site U1332 are consistent with those obtained from Site U1331 and multiple sites drilled during ODP Leg 199, in particular Site 1220 (Shipboard Scientific Party, 2002b).

Approximately $8 \mathrm{~m}$ above the Eocene-Oligocene transition in Hole U1332C, a prominent sharp contact (interval 320-U1332C-9H-2, $95 \mathrm{~cm}$ ) occurs be- 
tween very pale brown (10YR 8/2) radiolarian nannofossil ooze to overlying brown (10YR 5/3) radiolarian nannofossil ooze (Fig. F9). In turn, this radiolarian nannofossil ooze transitions uphole into light gray (10YR 7/2) nannofossil ooze with radiolarians over an $\sim 3.5 \mathrm{~m}$ thick interval. Magnetostratigraphy and radiolarian and nannofossil biostratigraphy, together with physical property series from the WRMSL and Section Half Multisensor Logger (SHMSL), demonstrate that this $3.5 \mathrm{~m}$ thick sequence is a duplication of latest Eocene through earliest Oligocene age interval cored below (see "Biostratigraphy," "Paleomagnetism," "Physical properties," and "Stratigraphic correlation and composite section"). A similar duplicated (or replicated) sequence is also documented in Hole U1332B, but in this hole the sharp contact between pale earliest Oligocene sediments and darker overlying latest Eocene sediments occurs in the core catcher (Sample $320-\mathrm{U} 1332 \mathrm{~B}-8 \mathrm{H}-\mathrm{CC}, 3 \mathrm{~cm}$ ) and is consequently disturbed (Fig. F9). This duplicated sequence, with its sharp basal contact, is interpreted to result from a mass movement, probably a slump or slide that reworked older sediments (that happened to be of Eocene-Oligocene transition age) into sediments of early Oligocene (C12r) age (Fig. F9). The lithostratigraphic integrity of the Eocene-Oligocene transition that lies $\sim 8 \mathrm{~m}$ deeper in the section in all holes cored at Site U1332 is not affected (Fig. F8) and is very well correlated with that at Site 1220 using WRMSL physical property data (see "Stratigraphic correlation and composite section").

\section{Discussion}

\section{Eocene intervals with nannofossil ooze}

The dominant lithology of Unit IV at Site U1332 is radiolarian ooze, but this unit also contains four discrete intervals where nannofossil ooze and radiolarian nannofossil ooze is a second major lithology (Fig. F3; see "Site U1332 smear slides" in "Core descriptions"). Two of these carbonate-rich intervals are comparatively thin ( $\leq 5 \mathrm{~m}$ thick each), consist entirely of radiolarian nannofossil ooze, and occur in Subunit IVa. The third carbonate-rich interval is thicker $(\sim 25 \mathrm{~m})$, consists of an alternating sequence of nannofossil ooze and radiolarian nannofossil ooze, and spans almost all of Subunit IVb. The fourth interval occurs in the upper half of Subunit IVc (Fig. F3) and consists of alternating radiolarian ooze with clay and radiolarian nannofossil ooze. All four intervals show $\mathrm{CaCO}_{3}$ contents (as measured by coulometry) that are above background for Unit IV with up to $60 \mathrm{wt} \%$ obtained in Subunit IVb (Fig. F3) and are separated by intervals dominated by radiolarian ooze. According to shipboard magnetostrati- graphic results, the uppermost of these carbonaterich intervals at Site U1332 occurs in sediments of late Eocene age (C16n.2n to C16r; $35.5-36.5 \mathrm{Ma}$ ) (Fig. F3). The other three carbonate-rich intervals fall in the middle Eocene (estimated ages: Interval $2=$ C18n.1n to C18n.1r, $\sim 38.5-39.5 \mathrm{Ma}$; Interval $3=$ within C18r middle RP15 to upper RP14 radiolarian zone, $~ 40-41.5 \mathrm{Ma}$; Interval $4=$ middle to lower part of RP14, 42.5-43.8 Ma). These lithostratigraphic results are broadly consistent with those of Leg 199, especially ODP Sites 1218 and 1219 (Shipboard Scientific Party, 2002a) and the carbonate accumulation events (CAE [2?], 3, 4, and 6/7) of Lyle et al. (2005) that have been used to refine the Paleogene record of the CCD for the equatorial Pacific (Shipboard Scientific Party, 2002a; Van Andel, 1975).

\section{Porcellanite and chert}

In Subunit IVc, layers and pebbles of very dark brown (10YR 2/2) partially to well-lithified claystones, often layered or even laminated, are observed within alternating sequences of radiolarian nannofossil ooze, radiolarian ooze, and nannofossil radiolarian ooze of middle Eocene age in Cores 320U1332A-15X through 17X. Within this sequence (Core 320-U1332A-16X $=\sim 130$ wireline log matched depth below seafloor [WMSF], $\sim 135$ CSF) (see "Downhole measurements"), a small peak above a stepwise change in NGR is observed in the downhole logging data but no equivalent feature is seen in the core NGR data. In hand specimen, the partially lithified claystones cleave along bedding planes that are particularly rich in clay and the well-lithified specimens exhibit some concoidal fracture indicative of partial secondary silicification. In a single sample (320-U1332-17X-1, 0-4 cm), a black very hard and vitreous pebble with distinct concoidal fracture was recovered. During thin section preparation this single sample proved significantly more resistant to cut by rock saw than the other samples taken from Subunit IVc for this purpose.

In thin section, all of the samples taken from Subunit IVc at Site U1332 show evidence of partial secondary silicification (see "Site U1332 smear slides" in "Core descriptions"). All but one of these samples are porcellanites (Fig. F6A, F6B, F6C). The single black very hard and vitreous pebble (Sample 320U1332-17X-1, 0-4 cm), is termed "chert" (Fig. F6D; see "Site U1332 smear slides" in "Core descriptions"). In thin section, major components of the porcellanites are clay minerals, microcrystalline quartz, opaques (Fe oxides), and calcite, as well as biogenic shells and fragments from radiolarians and foraminifers. Foraminifer tests are predominantly filled with microcrystalline quartz. In many cases the 
original calcite mineralogy of the foraminifer test wall is preserved, but some are partially or entirely replaced by diagenetic silica. All of the porcellanite samples retain a distinct sedimentary fabric, with layers rich in clay, radiolarians and foraminifers, and microcrystalline quartz. Chert is mainly composed of microcrystalline quartz, clay minerals, and opaques. Areas show a breccia-like fabric of angular material with infill of chalcedonic quartz (Fig. F6D). No biogenic components were observed within the chert.

\section{Summary}

At Site U1332, Eocene seafloor basalt is overlain by $\sim 150.4 \mathrm{~m}$ of pelagic sediments that are divided into five major lithologic units and subunits. Sediments are dominated by radiolarian and nannofossil ooze with varying amounts of clay and can be correlated with Sites 1219 and 1220 using biostratigraphic, magnetostratigraphic, and cyclostratigraphic (magnetic susceptibility and GRA density) results. The early Miocene sedimentary sequence is dominated by clay with radiolarians followed downhole by a late Oligocene alternation of radiolarian ooze with clay, nannofossil ooze with radiolarians, and nannofossil ooze. The early Oligocene is predominantly characterized by white nannofossil ooze with minor intercalations of radiolarian nannofossil ooze in the middle early Oligocene. The early middle Eocene sequence is very low in carbonate followed by a porcellanite interval of $\sim 5 \mathrm{~m}$. The middle through late Eocene section (Hole U1332A; 95-140 CSF) is dominated by radiolarian ooze with varying amounts of clay, whereas nannofossil ooze is a secondary major lithology and occurs in four distinct intervals that broadly correlate with the lithostratigraphic results of Leg 199 and the CAEs of Lyle et al. (2005). The Eocene/Oliocene boundary is marked by a transition from dark brown radiolarian ooze to pale brown nannofossil ooze with radiolarians. A transition from Eocene siliceous sedimentation to Oligocene carbonate deposition is also observed in sediments from several other sites in the equatorial Pacific Ocean (e.g., Sites 1218 and 1219 and DSDP Sites 161 and 162) and probably reflects a deepening of the CCD associated with Antarctic glaciation (van Andel et al., 1975; Coxall et al., 2005).

\section{Biostratigraphy}

At Site U1332, we recovered a $148 \mathrm{~m}$ thick sequence of lower Miocene-lower middle Eocene radiolarian ooze, radiolarian clays with nannofossils, nannofossil ooze, and chert/porcellanite. The uppermost $10 \mathrm{~m}$ of clay is barren of calcareous microfossils and con- tains no age-diagnostic radiolarians. Nannofossil ooze is dominant in the Oligocene, and radiolarian ooze and clay are dominant in the Miocene and Eocene. A poorly recovered chert/porcellanite-rich sequence occurs in the lower middle Eocene. Radiolarians are present through most of the section and are well preserved in the Eocene. They provide a coherent high-resolution biochronology. Calcareous nannofossils are abundant and moderately well preserved in the Oligocene and poor to moderately well preserved in the Miocene and Eocene. Nannofossil datums and zonal determinations agree well with the radiolarian biostratigraphy; an integrated calcareous and siliceous microfossil biozonation is shown in Figure F10. A detailed age-depth plot including biostratigraphic and paleomagnetic datums is shown in Figure F11. Planktonic foraminifers are rare through the Oligocene and absent in the Miocene and Eocene. Benthic foraminifers are present through most of the section but are rare in all but the Oligocene lithologies. They indicate lower bathyal to abyssal paleodepths.

\section{Calcareous nannofossils}

Calcareous nannofossil biostratigraphy is based on analysis of core catcher samples from all three holes and from additional samples from each core section, predominantly from Hole U1332A. Depth positions and age estimates of biostratigraphic marker events are shown in Table T3. Nannofossils are abundant in the nannofossil oozes of the Oligocene and are consistently present through the Eocene, excepting short barren intervals in Cores 320-U1332A-9H through $12 \mathrm{H}$ and $15 \mathrm{X}$ through $17 \mathrm{X}$, where radiolarian ooze with clay lithology dominates. When present in radiolarian clays and basal dark brown clays, nannofossils are common to abundant, but typically etched, and characterized by abundant disaggregated and/or fragmented placolith shields. Discoasters are much less affected by etching and are virtually the only nannofossils present in several lower middle Eocene and lower Miocene samples. In the nannofossil ooze lithology, preservation is moderately good.

The clay of Unit I in the uppermost portion of the section (0-17.4 m CSF) is barren of calcareous nannofossils. The interval from Samples 320-U1332A$3 \mathrm{H}-4,100 \mathrm{~cm}$, to $4 \mathrm{H}-\mathrm{CC}(18.90-32.95 \mathrm{~m} \mathrm{CSF})$ yields low diversity and relatively poorly preserved nannofossil assemblages dominated by Discoaster deflandrei and Triquetrorhabdulus carinatus. The presence of rare Sphenolithus delphix in Sample 320-U1332A-3H-CC (23.51 $\mathrm{m} \mathrm{CSF}$ ) is indicative of a short interval (23.1$23.2 \mathrm{Ma}$ ) within Zone NN1, very close to the Oligocene/Miocene boundary. 
The upper Oligocene interval yields low diversity nannofossil assemblages, and the most distinct bioevent is the top of Sphenolithus predistentus in Sample 320-U1332A-5H-1, $80 \mathrm{~cm}$ (33.20 m CSF). The marker species Sphenolithus ciperoensis is rare and sporadically distributed through much of the upper Oligocene, so the Zone NP24/NN1 boundary cannot be determined. The crossover from Triquetrorhabdulus longus to T. carinatus is an intra-Zone NP25 event $(24.7 \mathrm{Ma})$ and occurs between Samples 320-U1332A$4 \mathrm{H}-2,60 \mathrm{~cm}$, and $4 \mathrm{H}-3,60 \mathrm{~cm}(25.0$ and $26.50 \mathrm{~m}$ CSF). Very small specimens $(<4 \mu \mathrm{m})$ of $S$. ciperoensis occur alongside rare Sphenolithus distentus between Samples 320-U1332A-5H-1, $80 \mathrm{~cm}$, and $6 \mathrm{H}-3,70 \mathrm{~cm}$, but the two species cannot be reliably distinguished because of small size and the occurrence of intermediate morphologies. As a result, we have not differentiated Zones NP24 and NP23. The base of $S$. distentus is an intra-Zone NP23 datum (30 Ma) and occurs in Sample 320-U1332A-6H-5, 70 cm (48.60 m CSF).

The lower Oligocene Zones NP23 and NP22 are determined by the top of Reticulofenestra umbilicus in Sample 320-U1332A-7H-7, $80 \mathrm{~cm}$ (61.20 m CSF), and the top of Coccolithus formosus in Sample 320U1332A-8H-5, $50 \mathrm{~cm}$ (67.40 m CSF). The Eocene/Oligocene boundary lies between the top of $C$. formosus and the top of Discoaster saipanensis, which occurs in Sample 320-U1332A-10H-3, $80 \mathrm{~cm}$ (83.70 m CSF). The boundary is apparently complete at the resolution provided by the nannofossil biostratigraphy. This interval is associated with a lithologic change from pale nannofossil ooze to brown radiolarian clay.

The Eocene nannofossil Zones NP18-NP20 through NP14 are recognized using the top of Chiasmolithus grandis in Sample 320-U1332A-11H-6, 70 cm $(97.60$ $\mathrm{m}$ CSF); top of Chiasmolithus solitus in Sample 320U1332A-13H-1, $140 \mathrm{~cm}$ (109.80 m CSF); the total range of Nannotetrina fulgens from Samples 320U1332A-15X-2, $137 \mathrm{~cm}$ (128.77 m CSF), to 16X-2, 39 $\mathrm{cm}$ (137.39 m CSF); and the presence of Discoaster sublodoensis in Sample 320-U1332B-18X-CC (146.21 $\mathrm{m}$ CSF). The base of Dictyococcites bisectus, total range of Discoaster bifax, top and base of Nannotetrina, and top of Discoaster lodoensis datums were also useful in supporting these zonal determinations.

The dark brown clays resting on basalt in Hole U1332A are mostly barren of nannofossils, but several samples from Holes U1332B and U1332C contain age-diagnostic taxa indicative of Zone NP14. Samples 320-U1332B-18X-2, $48 \mathrm{~cm}$ (145.88 m CSF), and 18X-CC (146.21 m CSF) contain dissolution-affected assemblages that nevertheless contain common $D$. lodoensis and rare D. sublodoensis. In Hole U1332C, Sample 320-U1332C-18X-CC (147.25 m
CSF) contains an etched assemblage without D. 10 doensis but with rare Nannotetrina. These observations within a succession that was poorly recovered and which is largely barren of nannofossils suggests that the top of D. lodoensis and base of Nannotetrina datums occur within these lowermost sediments, indicating an age between 48.0 and 48.4 Ma.

\section{Radiolarians}

Radiolarian stratigraphy at Site U1332 spans the interval between Zone RN1 (base of the lower Miocene) and the upper part of Zone RP13 (middle Eocene) (Tables T4, T5, T6). At the top of the section the first two cores are barren of radiolarians (Table T7). The third core (Sample 320-U1332A-3H, 93-95 $\mathrm{cm})$ contains a highly mixed assemblage ranging in age from middle Eocene through Miocene. The youngest species found in this mixture (Theocorythium vetulum) has a first appearance at $\sim 7 \mathrm{Ma}$. This sample is probably from the upper Miocene but could be mixed with still younger, nonfossiliferous sediments. Preservation of the lower Miocene and Oligocene assemblages is generally poor to moderate, with the common occurrence of reworked, older microfossils.

Preservation improves somewhat in the lower Oligocene (Zone RP20); however, near the base of the Oligocene the sequence of first and last appearances of species within Zone RP20 seems to be repeated in the lower part of Core 320-U1332A-8H and the upper part of Core 9H. The base of Core 9H (Sample 320U1332A-9H, 92-98 cm) is within the upper Eocene Zone RP19. There is substantial reworking of older middle Eocene microfossils in the Eocene part of Core 9H extending down into Cores 320-U1332A$10 \mathrm{H}$ and $11 \mathrm{H}$. Radiolarians are generally abundant and well preserved throughout the Eocene section.

The oldest radiolarian-bearing sediments are found in Cores 320-U1332C-16X and 17X (Zone RP13). The lowermost cores in all three holes at this site are barren of radiolarians.

\section{Diatoms}

Diatoms were examined in core catcher samples from Holes U1332A-U1332C. The examined sequence represents the interval extending from the Bogorovia veniamini Zone through the Coscinodiscus excavatus Zone of Barron $(1985,2006)$ and Barron et al. (2004). Diatoms range in abundance from rare to abundant. Diatom preservation is variable but is generally poor to moderate. The intervals from Cores $320-\mathrm{U} 1332 \mathrm{~A}-1 \mathrm{H}$ and $2 \mathrm{H}, 320-\mathrm{U} 1332 \mathrm{~B}-1 \mathrm{H}$ and $2 \mathrm{H}$, and $\mathrm{U} 1332 \mathrm{C}-1 \mathrm{H}$ are barren of or contain rare diatoms. The interval is unzoned. 
The interval from Samples 320-U1332A-3H-CC through $5 \mathrm{H}-\mathrm{CC}$ is assigned to the $B$. veniamini Zone based on the occurrence of $B$. veniamini in these samples without Rocella gelida. Supporting these zonal assignments is the occurrence of Cavitatus jouseanus and Rocella vigilans in Sample 320-U1332A-5H-2, $115-116 \mathrm{~cm}$; the occurrence of Rossiella symmetrica in Sample 320-U1332A-4H-4, 110-111 cm; and the occurrences of Cestodiscus kugleri, $R$. vigilans, and $C$. jouseanus in Samples 320-U1332A-4H-CC and 320U1332C-5H-CC.

Samples 320-U1332A-6H-CC and 320-U1332C-6HCC are assigned to the $R$. vigilans Zone based on the occurrence of $R$. vigilans without $B$. veniamini. The occurrence of Kozloviella minor and C. jouseanus in Sample 320-U1332C-6H-CC suggests placement of this sample into Subzone $\mathrm{C}$ of this zone, but such a zonal assignment is tentative given the typical poor state of diatom preservation. The Cestodiscus trochus Zone was not recognized because of sample spacing and/or preservation.

The C. excavatus Zone is recognized from Samples 320-U1332A-7H-4, 110-111 cm, through 8H-CC based on the occurrence of $C$. excavates in this interval. The occurrence of $C$. trochus and Cestodiscus robustus in occasional samples through this interval support this zonal assignment.

Diatoms are typically rare or absent from samples below Core 320-U1332A-8H. The exceptions are Samples 320-U1332A-13H-2, 100-101 cm, and 320U1332C-13H-CC, which contain few diatoms with poor preservation. The assemblage is representative of the middle Eocene. Sample 320-U1332A-13H-2, $100-101 \mathrm{~cm}$, contains specimens of Triceratium brachitium and Hemiaulus spp. Sample 320-U1332C$13 \mathrm{H}-\mathrm{CC}$ contains specimens of Triceratium inconspicum and Hemiaulus spp.

\section{Planktonic foraminifers}

Core catcher samples were analyzed from all three holes, and additional samples were taken in Hole U1332A (two per core) from any light-colored sediment intervals, which we assumed had a higher carbonate content. Planktonic foraminifers are absent from the Miocene and Eocene sediments but are consistently present in the Oligocene (from Zone $\mathrm{O} 6$ to the latest Eocene/earliest Oligocene); however, distinction of zones between Zone $\mathrm{O} 2$ and the late Eocene was hindered by the absence of age-diagnostic taxa of Hantkenina spp., Turborotalia cerroazuloensis, and Pseudohastigerina naguewichensis. Depth positions and age estimates of biostratigraphic marker events identified are shown in Table T8. Taxon ranges and abundances are shown in Table T9. Planktonic foraminifer assemblages show good to moderate preservation in the upper Oligocene, but both preservation and abundance of planktonic foraminifers decrease downcore. We note that a higher diversity of Oligocene taxa is recorded at Site U1332 than at Site U1331, 20 versus 12 species, respectively, which is consistent with the better preservation of fauna observed at this site (see Table T9).

The lowermost part of planktonic foraminifer Zone O6 was inferred between Samples 320-U1332A-3H-7, $75-77 \mathrm{~cm}$, and $4 \mathrm{H}-7,38-40 \mathrm{~cm}$, and in Sample 320U1332B-5H-CC based on the presence of a number of different Dentoglobigerina spp., which range to the latest Oligocene (Olsson et al., 2006), and the absence of Paragloborotalia opima, Paragloborotalia kugleri, and Paragloborotalia pseudokugleri. A Zone O6 assignment for these samples is also consistent with nannofossil (Zone NP24) and radiolarian (Zone RP21) determinations. The presence of the biostratigraphic marker species $P$. opima indicates the presence of planktonic foraminifer Zones O2-O5 between Samples 320-U1332A-5H-2, 100-102 cm, and 6H-CC, in Sample 320-U1332B-6H-CC, and in Samples $320-\mathrm{U} 1332 \mathrm{C}-4 \mathrm{H}-\mathrm{CC}$ through $5 \mathrm{H}-\mathrm{CC}$. The general absence of age-diagnostic Oligocene taxa, assumed to be dissolution susceptible based on their general absence here and during biostratigraphic investigations during ODP Leg 199 (Shipboard Scientific Party, 2002a), hindered further differentiation of the Oligocene. An exception is in Sample 320U1332C-5H-CC where Globigerina angulisuturalis and $P$. opima were both found, which allowed the identification of planktonic foraminifer Zones O4 and O5. However, the absence of Chiloguembelina cubensis prevented further differentiation between Zones O4 and O5. Typical Oligocene taxa identified in samples were Catapsydrax dissimilis, Catapsydrax unicavus, Dentoglobigerina tripartita, Dentoglobigerina galavisi, Dentoglobigerina pseudovenezuelana, Globoquadrina euapertura, Globoquadrina venezuelana, Paragloborotalia nana, Subbotina angiporoides, Subbotina utilisindex, and Turborotalia increbescens. Below Samples 320U1332A-6H-CC, 320-U1332B-7H-CC, and 320U1332C-6H-CC, the low abundance of planktonic foraminifers coupled with the absence of age-diagnostic taxa meant that the assemblage could only be assigned to a broad zonal range (e.g., Zones E13-O2).

\section{Benthic foraminifers}

Benthic foraminifers were examined semiquantitatively in three Site U1332 holes. Benthic foraminifers occurred continuously in calcareous nannofossil ooze of the Oligocene, whereas they were generally rare in radiolarian ooze of the Eocene. Occurrence of benthic foraminifers at this site is shown in Table T10. 
The upper two samples in Hole U1332A (320U1332A-1H-CC and 2H-CC; 3.86-13.62 m CSF) did not contain benthic foraminifers. In the interval from Samples 320-U1332A-3H-CC through 7H-CC (23.51-61.49 m CSF), Nuttallides umbonifer, Oridorsalis umbonatus, Cibicidoides mundulus, Globocassidulina subglobosa, and Gyroidinoides spp. were common and Cibicidoides havanensis and Cibidoides grimsdalei were subordinate. O. umbonatus and Cibicidoides spp. were generally common in the lower part of the interval (maximum $=24 \%$ and $16 \%$, respectively), whereas $N$. umbonifer was abundant in the upper part of the interval (maximum $=22 \%)$. A similar faunal transition was recognized in Hole U1332B (Samples 320-U1332B4H-CC through 8H-CC; 29.61-67.47 $\mathrm{m} \mathrm{CSF}$ ) and Hole U1332C (Samples 320-U1332C-4H-CC through 9H-CC; 36.52-75.91 m CSF). In addition, tubeshaped agglutinated forms (e.g., Rhizammina spp.) and Reophax spp. were sometimes abundant (maximum $=47 \%$ and $13 \%$, respectively) in the uppermost part of the interval (e.g., Sample 320U1332B-3H-CC; $19.97 \mathrm{~m}$ CSF). Preservation of foraminifer tests is very good to good. These faunal compositions indicate lower bathyal and abyssal paleodepths during the Oligocene, based on van Morkhoven et al. (1986). The Oligocene fauna are characterized by abundant calcareous hyaline forms, such as N. umbonifer, O. umbonatus, C. mundulus, G. subglobosa, and Gyroidinoides spp., and are similar to those observed in previous studies in the eastern equatorial Pacific (Site 573, Thomas, 1985; Sites 1218 and 1219, Nomura and Takata, 2005). However, assemblages dominated by agglutinated foraminifers occur much earlier (late Oligocene) at this site than at Sites 1218 and 1219. This temporal offset may be represent a preservational bias caused by the greater water depth at this site than those found at Sites 1218 and 1219.

Samples 320-U1332A-10H-CC through 15X-CC (89.89-132.93 m CSF) rarely contain benthic foraminifers. Agglutinated forms, such as Rhizammina spp. and Spiroplectammina spectabilis, were found with some calcareous hyaline taxa (e.g., Siphonodosaria antillea). Preservation of these tests was poor. Similar occurrences were also recognized in Samples 320-U1332A-9H-CC through 17X-CC (77.09-135.06 $\mathrm{m}$ CSF) and in Samples 320-U1332A-10H-CC through 17X-CC (85.53-139.91 m CSF). Calcareous hyaline forms, such as O. umbonatus, Nuttallides truempyi, Cibicidoides eocanus, and C. grimsdalei, were present at least in two horizons, Samples 320U1332A-11H-CC (98.52 m CSF) and 13H-CC (118.38 $\mathrm{m}$ CSF). Similar occurrences were also recognized in Samples 320-U1332B-13H-CC (110.76 m CSF) and
10H-CC through 17X-CC (85.53-139.91 m CSF). However, preservation of calcareous foraminifer tests was poor in the lower part of the study interval. These fauna suggest lower bathyal to abyssal paleodepth at this site in the middle to late Eocene. Faunal associations of these calcareous taxa in the middle to late Eocene are similar to those observed at Site U1331 and previous preliminary studies in the eastern equatorial Pacific (Shipboard Scientific Party, 2002a). Common occurrences of these calcareous foraminifers in Hole U1332A roughly coincide with high-carbonate intervals (see "Lithostratigraphy" and "Geochemistry") that may be related to carbonate accumulation events noted by Lyle et al. (2005).

\section{Paleomagnetism}

We measured and analyzed the remanent magnetization of archive-half sections from 47 cores (39 APC and 8 XCB cores) collected from three holes at Site U1332, excluding core catcher sections and other sections completely disturbed during coring. The natural remanent magnetization (NRM) of each section was measured before and after alternating-field (AF) demagnetization, with AF demagnetization typically consisting of a single $20 \mathrm{mT}$ step. When time permitted, NRM was also measured after 5, 10, and/ or $15 \mathrm{mT}$ steps.

We processed the data extracted from the Laboratory Information Management System (LIMS) database by removing all measurements collected from disturbed intervals, which are listed in Table T11, and all measurements that were made within $5 \mathrm{~cm}$ of the sections ends, which are biased by sample edge effects. Cleaned data are available for each hole by $\mathrm{AF}$ demagnetization level in Tables T12, T13, T14, T15, T16, T17, T18, T19, and T20. Curation errors occurred for Sections 320-U1332A-10H-4 and 14H-4, in which the halves that should have been treated as the working halves (with double lines along the core liner) were switched with the archive halves (with a single line along the core liner). We measured these two sections as archive halves before the errors were noted. Thus, the working halves were measured in the magnetometer instead of the archive halves and discrete samples were taken from the archive halves instead of the working halves. In Tables T12, T16, T21, and T22, we corrected the declinations of samples from these sections by flipping them by $180^{\circ}$ (note that data in the LIMS database are not corrected). We also noticed that Section 320U1332C-6H overlaps Section 320-U1332C-7H by 3 $\mathrm{m}$ CSF. This happened because Core $6 \mathrm{H}$ was advanced $4 \mathrm{~m}$ but recovered $>7 \mathrm{~m}$ of core. The upper $2.6 \mathrm{~m}$ was slurry (soupy mixed sediments). To 
partially fix the overlap, we subtracted $2.6 \mathrm{~m}$ from the Core $6 \mathrm{H}$ depths. This brought the top of the good part of Core $6 \mathrm{H}$ beneath the base of Core 320$\mathrm{U} 1332 \mathrm{C}-5 \mathrm{H}$ and reduced the overlap between Cores $6 \mathrm{H}$ and $7 \mathrm{H}$ to $\sim 50 \mathrm{~cm}$ (Tables T19, T20).

For data from the $20 \mathrm{mT}$ demagnetization step, we computed the mean paleomagnetic direction for each core using Bingham statistics (Table T23) with a program developed by Tanaka (1999). Unlike Fisher statistics, Bingham statistics can treat bipolar data sets and compute a principal axis as well as two associated semiaxes of the data set. When a data set consists of a sufficient number of paleomagnetic direction data with normal or reversed polarity, this principal axis corresponds to the orientation of the normal or reversed polarity field. We used all declination and inclination data for the computation and adopted the resultant principal axes as the mean paleomagnetic directions. These mean directions were inverted when they were interpreted to be representative of reversed polarity. By subtracting the mean declination from each observed declination, the azimuth of the core can be approximately reoriented back into geographic coordinates as discussed in "Paleomagnetism" in the "Site U1331" chapter.

In the absence of other evidence, this reorientation method has ambiguity in distinguishing magnetic north and south. By correlating downhole polarity reversal sequences among holes, using distinct reversal patterns, and taking advantage of age constraints provided by biostratigraphy, it is fairly straightforward to determine a continuous polarity stratigraphy downhole and hence to obtain the correct azimuthal orientation of the core. This only breaks down when significant coring gaps occur or when rotation occurs between pieces of core within a single core, which is the case for all cores collected with the $\mathrm{XCB}$. Hence XCB cores are not reoriented, nor can we confidently determine polarity from these cores because the inclination is generally too shallow at paleoequatorial sites, like all of the sites cored during Expedition 320/321. Reoriented declinations are provided for Holes U1332A-U1332C in Tables T16, T18, and T20, respectively, for the data collected after AF demagnetization at $20 \mathrm{mT}$.

We also measured NRM, mass, and bulk magnetic susceptibility for 91 discrete paleomagnetic samples, with one sample collected about every section from Hole U1332A. Of these, 76 samples were subjected to progressive AF demagnetization up to $60 \mathrm{mT}$. Remanence measurements and characteristic remanent magnetization (ChRM) directions computed using principal component analysis (PCA) are given in Tables T21 and T22, respectively. Magnetic susceptibil- ities and masses, along with volumes estimated using moisture and density (MAD) data (see "Physical properties"), are given in Table T24. This table also includes whole-core magnetic susceptibilities for depth intervals corresponding to the discrete samples, which are used for checking the scale factor for converting the whole-core raw susceptibility meter measurements into true volume normalized susceptibility values $\left(0.68 \times 10^{-5}\right)$ (see "Paleomagnetism" in the "Methods" chapter).

\section{Results}

Downhole variations in paleomagnetic data from split-core and discrete samples and magnetic susceptibility data from whole-core and discrete samples are shown in Figures F12, F13, and F14. As is typical for cores from DSDP, ODP, and IODP (e.g., Shipboard Scientific Party, 2002a), Site U1332 cores suffer a substantial drilling overprint. The overprint is primarily a viscous isothermal remanent magnetization (IRM), which results from the sediments residing inside the relatively magnetic BHA, drill pipe, and steel core barrel (and, to a lesser extent, the nonmagnetic core barrel) for about 15-45 min from the time it is collected until it is removed from the core barrel on the rig floor.

The most obvious evidence of the overprint is the steep inclination (typically $\sim 70^{\circ}-80^{\circ}$ ) measured prior to demagnetization. After AF demagnetization at 10 to $20 \mathrm{mT}$, the inclination becomes very shallow in general, as expected for sediments deposited near the equator. The effect and removal of the drilling overprint are evident from AF demagnetization behavior of the discrete samples (Fig. F15).

Following removal of the drilling overprint, a stable component of magnetization is resolved for AF demagnetization between 10 and $60 \mathrm{mT}$ (Fig. F15). We interpret this ChRM to be the primary depositional remanent magnetization. Discrete samples have ChRM directions, as determined with PCA, that commonly agree within a few degrees with those of the coeval intervals of the split-core samples (Table T22; Fig. F12), for which the $20 \mathrm{mT}$ demagnetization results are used as an estimate of the ChRM. This indicates that any overprint generally is successfully removed with AF demagnetization up to $20 \mathrm{mT}$. Within some intervals, however, the inclinations remain steep even after demagnetization, indicating the drilling overprint still dominates in these intervals. For example, Core 320-U1332A-2H (4.0-13.4 m CSF) has a mean inclination of $-76.09^{\circ}$ (Table T23). Inclinations and remanent magnetization intensities from a few discrete samples from this core do not agree with those from the split-core samples (Fig. F12). These are mainly limited to the upper $20 \mathrm{~m}$ in 
Hole U1332A, and it is considered that in this interval the split-core samples were more strongly overprinted.

It is likely that a small overprint remains in many intervals even after magnetic cleaning because the inclinations are not symmetrically distributed about zero. Instead, they are biased several degrees toward positive values, which could possibly result from a Brunhes field overprint or a drilling overprint. Regardless, any overprint is sufficiently small that variations in inclination can be used to aid in determining polarity even though the mean inclination at the site is very shallow. In such cases, reversed polarity intervals consistently have slightly shallower inclination than normal polarity intervals. The declination is, however, the primary parameter used for polarity determination, as it changes by $\sim 180^{\circ}$ across polarity reversals (Figs. F12, F13, F14).

\section{Magnetostratigraphy}

Interpretation of the magnetostratigraphy is relatively uncomplicated, as summarized in Table T25 and Figures F16, F17, and F18. We consider that the bottom of the APC cores extended down through reversal boundaries Chron C19r/C20n (42.536 Ma) for Hole U1332A (124.70 m CSF) and Chron C18n.2n/C18r (40.084 Ma) for Holes U1332B (102.25 m CSF) and U1332C (106.95 m CSF). The chron boundary closest to the Oligocene/Miocene boundary (C6Cn.2n/C6Cn.2r; 23.030 Ma) occurs at $22.40 \mathrm{~m} \mathrm{CSF}$ in Hole U1332A and at $22.88 \mathrm{~m}$ CSF in Hole U1332C. The Eocene/Oligocene boundary occurs just below the Chron C13n/C13r reversal $(33.705 \mathrm{Ma})$, which is at $75.33 \mathrm{~m}$ CSF in Hole U1332A and $74.33 \mathrm{~m}$ CSF in Hole U1332B. The magnetostratigraphies for the three holes are compared in Figure F19.

Complications include (1) the upper few cores of each hole and (2) a slump that occurs just above the Eocene/Oligocene boundary. Paleontological age estimates from core catcher samples are Quaternary age for Core 320-U1332A-1H, 23.29-22.98 Ma for Core 3H, 22.26-22.35 Ma for Core 320-U1332B-3H, and 21.9-22.2 Ma for Core 320-U1332C-2H (see "Biostratigraphy"). No age estimates were obtained for Cores 320-U1332A-2H, 320-U1332B-1H and 2H, and $320-\mathrm{U} 1332 \mathrm{C}-1 \mathrm{H}$. Age data indicate that hiatuses occur between sediments of Pleistocene-Pliocene and early Miocene age. We tentatively assign geomagnetic chrons from C1n to C2Ar for Cores 320U1332A-1H and $2 \mathrm{H}, \mathrm{C} 1 \mathrm{n}$ to C2An.3n for Cores 320$\mathrm{U} 1332 \mathrm{~B}-1 \mathrm{H}$ and $2 \mathrm{H}$, and $\mathrm{C} 1 \mathrm{n}$ to $\mathrm{C} 2 \mathrm{r}$. $1 \mathrm{r}$ for Core $320-$ U1332C-1H. The hiatuses are considered to occur below these horizons. Below the hiatus, we identify the occurrence of Chron C6An.1r at 14.20 m CSF in Hole
U1332A, Chron C6n at $13.60 \mathrm{~m}$ CSF in Hole U1332B, and Chron C5En at $12.30 \mathrm{~m}$ CSF in Hole U1332C, which agree with paleontological age constraints (Figs. F16, F17, F18).

Lithostratigraphic observations, paleomagnetic data, magnetic susceptibility data, and paleontological age estimates from core catcher sections suggest that Cores 320-U1332A-8H and 9H, 320-U1332B-8H and $9 \mathrm{H}$, and $320-\mathrm{U} 1332 \mathrm{C}-9 \mathrm{H}$ penetrated a slump (see "Lithostratigraphy," "Biostratigraphy," and "Physical properties"). The slump occurs just above the Eocene/Oligocene boundary. As a result, the upper part of Chron C13n and the lower part of Chron $\mathrm{C} 12 \mathrm{r}$ are repeated in the sedimentary succession as evidenced by the polarity reversal sequence and the distinct and coherent variations in remanent magnetization (Figs. F20, F21, F22). The basal surface of the slump (the décollement) is a sharp contact, with sediment above and below having sustained no visible or measurable deformation.

\section{Geochemistry}

\section{Sediment gases sampling and analysis}

Headspace gas samples were taken at a frequency of one sample per core in Hole U1332A as part of the routine environmental protection and safety monitoring program. All headspace samples had nondetectable levels of methane $\left(\mathrm{C}_{1} ;<1 \mathrm{ppmv}\right)$, with no higher hydrocarbons, consistent with the low organic carbon content of these sediments.

\section{Interstitial water sampling and chemistry}

Twenty interstitial water samples were collected using the whole-round squeezing approach (Table T26). Additionally, 43 samples were collected using Rhizon samplers from Sections 320-U1332B-4H-1 through 7H-6 with a sampling frequency of two samples per section (Table T27). These sections were selected for Rhizon sampling because of a decrease in alkalinity revealed by the whole-round samples (Fig. F23). Rhizons were applied as described in "Geochemistry" in the "Site U1331" chapter. Chemical constituents were determined according to the procedures outlined in "Geochemistry" in the "Methods" chapter. In the following, we first describe the overall site geochemistry, combining the squeezed and Rhizon samples into single profiles with depth, and then present a more detailed comparison of squeezed and Rhizon samples in the depth interval where they overlap.

Chlorinity varies relatively little with depth, with values ranging mainly from 556 to $570 \mathrm{mM}$ (Fig. F23). However, chlorinity values reveal a distinct in- 
crease from 556 to $565 \mathrm{mM}$ in the uppermost $30 \mathrm{~m}$ CSF, potentially reflecting the change from the more saline ocean at the Last Glacial Maximum to the present (Adkins and Schrag, 2003). Alkalinity ranges from 2.3 to $3.4 \mathrm{mM}$. Alkalinities increase in the uppermost $30 \mathrm{~m}$ CSF from 2.3 to $3.1 \mathrm{mM}$ and then drop to a distinct minimum of $\sim 2.3$ around $40 \mathrm{~m}$ CSF. Below $50 \mathrm{~m}$ CSF alkalinities increase steadily toward a value of $3.4 \mathrm{mM}$ in the deepest sample. Sulfate concentrations are relatively constant and near seawater values. Low alkalinities and high sulfate concentrations indicate that organic matter supply is not sufficient to drive redox conditions to sulfate reduction. Dissolved phosphate concentrations are $\sim 2$ $\mu \mathrm{M}$ in the shallowest sample, decreasing to below detection limit in the uppermost $\sim 25 \mathrm{~m}$ CSF. Dissolved manganese is $8-9 \mu \mathrm{M}$ from 7 to $11 \mathrm{~m} \mathrm{CSF}$, with peak manganese values shallower than the peak dissolved iron value of $\sim 1.0 \mu \mathrm{M}$ at $\sim 11 \mathrm{~m}$ CSF. Because of the high sulfate concentrations, dissolved $\mathrm{Ba}$ concentrations are low and relatively homogeneous, with values between 2 and $3 \mu \mathrm{M}$.

Concentrations of dissolved silicate increase with depth from $\sim 400$ to $\sim 1000 \mu \mathrm{M}$. Superimposed on the gradual increase in dissolved silicate with depth is a pronounced minimum at $\sim 80 \mathrm{~m}$ CSF. This is slightly deeper than the color change from light to dark that occurs at the lithologic Unit III to Unit IV transition (see "Lithostratigraphy").

Calcium concentrations increase slightly with depth, with values ranging from 10 to $12 \mathrm{mM}$ and a local minimum around $50 \mathrm{~m}$ CSF (Fig. F23). Magnesium concentrations are relatively constant, ranging from 50 to $53 \mathrm{mM}$ (Figs. F23).

Lithium concentrations decrease from $\sim 26 \mu \mathrm{M}$ at the surface to $20 \mu \mathrm{M}$ near basement, with the strongest decrease apparent between 40 and $50 \mathrm{~m}$ CSF. Strontium shows relatively little variation, with concentrations ranging from 77 to $93 \mu \mathrm{M}$. Boron concentrations range between 400 and $490 \mu \mathrm{M}$, slightly decreasing between 40 and $50 \mathrm{~m}$ CSF.

Interstitial water samples derived from Rhizon samplers (Fig. F24) and whole-round squeezing generally show good agreement (Fig. F25). Because these two data sets were collected in different holes (Hole $\mathrm{U} 1332 \mathrm{~B}$ is $20 \mathrm{~m}$ north of Hole U1332A), data are plotted in CCSF-A, to facilitate comparison. Elements that show good agreement with respect to absolute concentrations as well as observed trends include Li, K, and Sr. Magnesium and calcium show similar trends in both data sets but with constant offsets of 1.25 and $0.25 \mathrm{mM}$, respectively. These correspond to $2.5 \%$ of the measured values, and they might be related to day to day variability of the inductively coupled plasma-atomic emission spectros- copy (ICP-AES) analyses. However, $\mathrm{Mg} / \mathrm{Ca}$ ratios show a good agreement between both sampling techniques, irrespective of the applied corrections for $\mathrm{Mg}$ and $\mathrm{Ca}$. Boron concentrations are identical in the upper part of the investigated interval, but Rhizon samples are slightly enriched in boron in the lower part. However, it is unclear if this feature is an analytical or sampling artifact. The same holds true for alkalinity values. Between 28 and $30 \mathrm{~m}$ CCSF-A and 50 and $65 \mathrm{~m}$ CCSF-A both sampling techniques reveal results indistinguishable within typical analytical precision. Rhizon samples did not reproduce the distinct decrease in alkalinity centered at $40 \mathrm{~m}$ CCSFA obtained from the whole-round samples. Several aspects of Rhizon sampling might be responsible for this. First, Rhizon sampling was only conducted after the core sections were processed through the fast track system. Second, Rhizon sampling pulls a vacuum on the sediment to withdraw fluid. Third, because of work flow imposed by the rapidly acquired samples, alkalinities of the Rhizon samples were not measured directly after retrieval. We expect this third factor to have only small effects in these samples with no/limited sulfate reduction and relatively low alkalinities.

\section{Bulk sediment geochemistry: major and minor elements}

At Site U1332, bulk sediment samples for minor and major element analyses were distributed over the complete depth range to target all major lithologic units (0-150 m CSF; Hole U1332A). We analyzed concentrations of silicon, aluminum, iron, manganese, magnesium, calcium, sodium, potassium, titanium, phosphorus, barium, copper, chromium, scandium, strontium, vanadium, yttrium, and zirconium in the sediment by ICP-AES (Table T28).

Bulk sediment $\mathrm{SiO}_{2}$ ranges between 12 and $75 \mathrm{wt} \%$, with values around $50 \mathrm{wt} \%$ from 0 to $40 \mathrm{~m} \mathrm{CSF}$ and low values (10-20 $\mathrm{wt} \%$ ) between 40 and $65 \mathrm{~m}$ CSF. Below $70 \mathrm{~m} \mathrm{CSF}, \mathrm{SiO}_{2}$ concentrations vary between 40 and $75 \mathrm{wt} \%$. Concentrations of $\mathrm{Al}_{2} \mathrm{O}_{3}$ range from 0.5 to $13 \mathrm{wt} \%$, with values decreasing in the upper $60 \mathrm{~m} \mathrm{CSF}$ from 13 to $0.5 \mathrm{wt} \%$. Below $60 \mathrm{~m} \mathrm{CSF}, \mathrm{Al}_{2} \mathrm{O}_{3}$ concentrations are between 0.5 and $2 \mathrm{wt} \%$, with two peaks at 80 and $145 \mathrm{~m} \mathrm{CSF}$ with values of 6 and 4 $\mathrm{wt} \%$, respectively. A similar pattern is displayed by $\mathrm{TiO}_{2}(0.01-0.6 \mathrm{wt} \%), \mathrm{K}_{2} \mathrm{O}(0.25-2.4 \mathrm{wt} \%), \mathrm{Zr}(20-205$ ppm), and Sc (1.4-30 ppm).

Iron decreases from $6 \mathrm{wt} \% \mathrm{Fe}_{2} \mathrm{O}_{3}$ at the surface to 0.4 $\mathrm{wt} \%$ at $55 \mathrm{~m}$ CSF. Between 60 and $130 \mathrm{~m} \mathrm{CSF}$, concentrations vary between 1 and $5 \mathrm{wt} \%$. Below $140 \mathrm{~m}$ CSF, values increase up to $>13 \mathrm{wt} \%$ (measured value exceeded the calibrated concentration range). Simi- 
lar trends are shown by $\mathrm{MnO}$ (0.03 to >0.2 wt\%), $\mathrm{MgO}(0.03-21 \mathrm{wt} \%)$, copper (53 to >140 ppm) and vanadium (60 to $>330 \mathrm{ppm}$ ). The peak concentrations of $\mathrm{Mn}, \mathrm{Cu}$, and $\mathrm{V}$ could not be quantified because they exceeded the calibrated range (see Table T9 in the "Methods" chapter).

Calcium $(\mathrm{CaO})$ ranges from 0.4 to $40 \mathrm{wt} \%$, with high values corresponding to the minimum in $\mathrm{SiO}_{2}$ and $\mathrm{Al}_{2} \mathrm{O}_{3}$ between 40 and $70 \mathrm{~m} \mathrm{CSF}$ and at $80 \mathrm{~m} \mathrm{CSF}$. Strontium concentrations range from 60 to $>700$ ppm, showing a similar pattern to $\mathrm{CaO}$.

\section{Bulk sediment geochemistry: sedimentary inorganic and organic carbon}

$\mathrm{CaCO}_{3}$, IC, and TC concentrations were determined on sediment samples from Hole U1332A (Table T29; Fig. F26). $\mathrm{CaCO}_{3}$ concentrations range between $<1$ and $90 \mathrm{wt} \%$. In the uppermost $17 \mathrm{~m} \mathrm{CSF}, \mathrm{CaCO}_{3}$ concentrations are very low $(<1 \mathrm{wt} \%)$, below which concentrations vary up to $70 \mathrm{wt} \%$ at depths from $\sim 17$ to $32.6 \mathrm{~m}$ CSF. From 32.6 to $75.5 \mathrm{~m} \mathrm{CSF}, \mathrm{CaCO}_{3}$ concentrations are consistently very high (48-90 $\mathrm{wt} \%$ ), and between 75.5 and $110 \mathrm{~m} \mathrm{CSF}, \mathrm{CaCO}_{3}$ concentrations are low, except for a high of $\sim 40 \mathrm{wt} \%$ at $98 \mathrm{~m}$ CSF. Below $98 \mathrm{~m} \mathrm{CSF}, \mathrm{CaCO}_{3}$ concentrations are variable, ranging from 1.2 to $60 \mathrm{wt} \%$. Variations in $\mathrm{CaCO}_{3}$ concentrations correspond to lithostratigraphic changes (see "Lithostratigraphy").

TOC concentrations were determined separately by a difference method and by an acidification method (see "Geochemistry" in the "Methods" chapter) (Table T29; Fig. F26). TOC concentrations determined by the normal difference method range from $<0.1$ to $1.6 \mathrm{wt} \%$ (Table T29). These values are probably overestimates because they are determined as a small difference between two numbers comparable in magnitude. Therefore, TOC analyses were performed only by the acidification method for the remaining PEAT sites. For Site U1332, we analyzed TOC on carbonate-free sediments after treatment by acidification. We calculated a detection limit of $0.03 \mathrm{wt} \%$ for the TC measurements using the acidification technique. TOC concentrations by this acidification method are very low throughout the sediment column, with a range from below the detection limit to $0.18 \mathrm{wt} \%$ (Fig. F26). In the uppermost $\sim 2.5 \mathrm{~m} \mathrm{CSF}$, TOC concentrations are slightly elevated (0.16-0.18 wt\%). TOC concentrations are very low (below detection limit) from 32.6 to $75.5 \mathrm{~m} \mathrm{CSF}$, corresponding to the depths where $\mathrm{CaCO}_{3}$ concentrations are high. Below $95 \mathrm{~m} \mathrm{CSF}$, TOC concentrations are slightly higher (0.04-0.05 wt\%).

\section{Physical properties}

Physical properties at Site U1332 were measured on whole cores, split cores, and discrete samples. WRMSL (GRA bulk density, magnetic susceptibility, and $P$-wave velocity), thermal conductivity, and NGR measurements comprised the whole-core measurements. Compressional wave velocity measurements on split cores and MAD analyses on discrete core samples were made at a frequency of one per undisturbed section in Cores 320-U1332A-1H through 18X. Compressional wave velocities were measured toward the bottom of sections. MAD analyses were located $10 \mathrm{~cm}$ below the carbonate analyses (see "Geochemistry"). Lastly, the SHMSL was used to measure spectral reflectance on archivehalf sections.

\section{Density and porosity}

GRA provided wet bulk density from whole cores (Fig. F27), and MAD samples gave a second, independent measure of wet bulk density, along with providing dry bulk density, grain density, water content, and porosity from discrete samples (Table T30; Fig. F28). MAD and GRA bulk density measurements display the same trends and are also similar in absolute values through the entire section (Fig. F28). Cross-plots of wet and dry bulk density versus GRA density show excellent correlation between MAD and GRA data (Fig. F29).

Generally, wet bulk density corresponds to changes in lithology (Fig. F27). Wet bulk density is $\sim 1.24 \mathrm{~g} /$ $\mathrm{cm}^{3}$ at the seafloor and varies between 1.2 and 1.25 $\mathrm{g} / \mathrm{cm}^{3}$ through Units I and II. A slight step toward lower values $\left(1.2 \mathrm{~g} / \mathrm{cm}^{3}\right)$ at $\sim 12 \mathrm{~m}$ CSF shows the change from clay- to radiolarian-dominated lithology. The top of Unit III is marked by an increase in density to $1.5 \mathrm{~g} / \mathrm{cm}^{3}$, with high-amplitude variation in this unit (from 1.4 to $1.6 \mathrm{~g} / \mathrm{cm}^{3}$ ). A sharp decrease in wet bulk density (to $\sim 1.2 \mathrm{~g} / \mathrm{cm}^{3}$ ) occurs at the base of Unit III. Wet bulk density is relatively uniform with low-amplitude variations at $\sim 1.2 \mathrm{~g} / \mathrm{cm}^{3}$ in Subunit IVa. An increase in wet bulk density accompanies the lithologic change toward more carbonate in Subunit IVb. Density is lower in Subunit IVc. An increase in GRA bulk density in Unit V is corroborated by a single discrete MAD wet bulk density value $\left(1.45 \mathrm{~g} / \mathrm{cm}^{3}\right)$.

Variation in grain density in Hole U1332A generally matches changes in lithology (Fig. F28). Grain density averages $2.7 \mathrm{~g} / \mathrm{cm}^{3}$ in Unit III. In other units grain density averages $2.5 \mathrm{~g} / \mathrm{cm}^{3}$ with variation from 2.1 to $2.8 \mathrm{~g} / \mathrm{cm}^{3}$ and a high of $2.9 \mathrm{~g} / \mathrm{cm}^{3}$ present near 
the seafloor. This variation is expected to be related to variations in the radiolarian content $($ opal $=2.2 \mathrm{~g} /$ $\mathrm{cm}^{3}$ ) and carbonate material $\left(\right.$ calcite $=2.7 \mathrm{~g} / \mathrm{cm}^{3}$ ).

Porosity averages $85 \%$ in Units I and II, decreases to $70 \%$ in Unit III (Fig. F28), and rises again to $~ 80 \%$ in Subunit IVa. Porosity averages $80 \%$ in Subunits IVb and IVc and Unit V.

\section{Magnetic susceptibility}

Whole-core magnetic susceptibility measurements correlate well with the major differences in lithology and changes in bulk physical properties (Fig. F27). Magnetic susceptibility values increase gradually through Unit I from $20 \times 10^{-5}$ to $40 \times 10^{-5}$ SI, with a major spike occurring at $12 \mathrm{~m} \mathrm{CSF}\left(100 \times 10^{-5} \mathrm{SI}\right)$. A decrease in susceptibility marks the top of Unit II, and susceptibility remains low to the top of Unit III, where it gradually rises to $\sim 10 \times 10^{-5}$ SI. The base of Unit III contains a sharp rise in susceptibility to $40 \times$ $10^{-5}$ SI. Magnetic susceptibility shows small amplitude variations in Unit IV, with a marked decrease in average magnetic susceptibility values from $28 \times 10^{-5}$ to $18 \times 10^{-5}$ SI at $\sim 100-108 \mathrm{~m}$ CSF. Susceptibility appears to be higher in Unit V; however, core recovery is incomplete in this interval.

\section{Compressional wave velocity}

\section{Shipboard results}

Compressional wave velocity was measured by the $P$ wave logger (PWL) on all whole cores from Holes U1332A-U1332C and by the insertion and contact probe systems on undisturbed sections of split cores from Hole U1332A (Table T31; Fig. F30), allowing determination of velocities in the $x-, y$-, and $z$-directions. Initial processing revealed an offset of $\sim 50 \mathrm{~m} / \mathrm{s}$ between PWL and discrete $x$ - and $y$-directions and a difference of $\sim 100 \mathrm{~m} / \mathrm{s}$ for the $x$-direction. Values returned from the PWL generally varied between 1400 and $1450 \mathrm{~m} / \mathrm{s}$-considerably lower than the expected values and the calibrated value for water at $1500 \mathrm{~m} / \mathrm{s}$. Trials with the water-filled core liner on the PWL and discrete contact probe suggested that core liner parameters were not being used in the PWL's processing computations. This has now been confirmed, and previously recorded PWL velocity data have been corrected by subtracting $2.617 \mu \mathrm{s}$ (the time taken for a $P$-wave to move through two layers of $2.8 \mathrm{~mm}$ thick core liner with a velocity of $2140 \mathrm{~m} / \mathrm{s}$ ) from the traveltime given by the PWL. Velocity was then recalculated using the time provided (corrected data have been uploaded into the database). This section discusses the corrected PWL data. Corrected whole-core and split-core data follow similar trends, with key features occurring at similar loca- tions (Fig. F30). An excellent correlation between PWL and $y$-axis values is observed from 0 to $80 \mathrm{~m}$ CSF. Z-axis measurements show good correlation in this interval with some values underestimated by $\sim 40 \mathrm{~m} / \mathrm{s}$. Below $80 \mathrm{~m} \mathrm{CSF}$ no $z$-axis measurements were obtained and the $y$-axis values significantly underestimate velocity $(\sim 1400 \mathrm{~m} / \mathrm{s})$ because the sediments are predominantly radiolarian ooze that is poorly cemented and so splits/fractures easily when the transducers are inserted. $X$-axis measurements are generally $\sim 80 \mathrm{~m} / \mathrm{s}$ faster than PWL values throughout the succession; this is expected to be related to the pressure applied to the sediments by the contact probes-increased sediment compactness, and thus traveltime.

PWL data show a limited relationship between velocity and lithology downhole (Fig. F30); the general trend is a slight velocity increase with depth. More information on the relationship between downhole trends in velocity and lithology can be detailed using the cross-plot of velocity (PWL) and wet bulk density (GRA) (Fig. F31). At low densities $\left(<1.2 \mathrm{~g} / \mathrm{cm}^{3}\right)$ all units show considerable variability in velocity. All units apart from Unit III show a very slight decrease in velocity (from 1600 to $\sim 1520 \mathrm{~m} / \mathrm{s}$ ) with increased density (from 1.2 to $1.45 \mathrm{~g} / \mathrm{cm}^{3}$ ). Unit III shows a correlation where density and velocity increase together and may relate to the increased carbonate content of this unit.

\section{Postcruise correction}

During the initial sampling of Hole U1337A, it was observed that $x$-direction velocities are consistently higher than other velocities and that PWL velocities are consistently low for Hole U1337A and all holes drilled at Sites U1331-U1336. It was determined that the high $x$-directed velocities are the result of using an incorrect value for the system delay associated with the contact probe (see "Physical properties" in the "Site U1337" chapter). Critical parameters used in this correction are system delay $=19.811 \mu \mathrm{s}$, liner thickness $=2.7 \mathrm{~mm}$, and liner delay $=1.26 \mu \mathrm{s}$. PWL velocities were corrected for Hole U1337A by adding a constant value that would produce a reasonable velocity of water $(\sim 1495 \mathrm{~m} / \mathrm{s})$ for the quality assurance/ quality control (QA/QC) liner (see "Physical properties" in the "Site U1337" chapter). These corrections have not been applied to the velocity data presented in this chapter.

\section{Natural gamma radiation}

NGR was measured on all whole cores at Site U1332 (Fig. F27). The highest NGR values are present at the seafloor ( 130 counts per second [cps]) and decrease rapidly, reaching $15 \mathrm{cps}$ at $5 \mathrm{~m}$ CSF. NGR increases in 
Unit I to $22 \mathrm{cps}$ at $11 \mathrm{~m} \mathrm{CSF}$ and then decreases to $~ 9$ cps at $15 \mathrm{~m}$ CSF. This feature appears in all three holes and is a useful independent check on stratigraphic correlation based on magnetic susceptibility and GRA measurements. NGR is relatively uniform throughout the remainder of the section; however, relatively small variations (5-10 cps) occur at various locations downhole and can be identified in all three holes. At the top boundary of Subunit IVa, NGR values increase sharply to 9 cps (at $75 \mathrm{~m} \mathrm{CSF}$ ) and decrease gradually to $6 \mathrm{cps}$ at $\sim 84 \mathrm{~m} \mathrm{CSF}$. A prominent shift of NGR in the gamma ray pass of the Hole U1332A borehole log at $131 \mathrm{~m}$ WSF (see "Downhole measurements") is not observed in the cores. NGR is slightly higher in the basal intervals recovered from Cores 320-U1332A-17X and 320-U1332B-18X.

\section{Thermal conductivity}

Thermal conductivity was measured on the third section of each core from Hole U1332A (Table T32). Thermal conductivity measurements show a strong dependence on porosity in intervals containing $>20 \%$ calcium carbonate (see "Geochemistry"). Thermal conductivity is $\sim 0.8 \mathrm{~W} /(\mathrm{m} \cdot \mathrm{K})$ in Units I and II (Fig. F32). In Unit III, values increase to between 1 and $1.2 \mathrm{~W} /(\mathrm{m} \cdot \mathrm{K})$. In Subunit IVa, values return to 0.8 $\mathrm{W} /(\mathrm{m} \cdot \mathrm{K})$. A single measurement in Subunit IVb suggests thermal conductivity is higher in this unit. Thermal conductivity has been used with borehole temperature to investigate heat flow (see "Downhole measurements").

\section{Reflectance spectroscopy}

Spectral reflectance was measured on split archive section halves from Holes U1332A-U1332C using the SHMSL (Fig. F33). The parameters $L^{*}$ (blackwhite), $a^{*}$ (green-red), and $b^{*}$ (blue-yellow) follow changes in lithology, with variations in $L^{*}$ and $b^{*}$ correlating very well to carbonate content, density, and magnetic susceptibility. The parameter $\mathrm{a}^{*}$ has a slightly more limited relationship with lithologic variation downhole. Carbonate-rich sediments are found in Unit III and Subunit IVb; these intervals are represented by a distinct increase in the $L^{*}$ and $b^{*}$ values in these sections. This feature is less obvious in the $\mathrm{a}^{*}$ record. The upper half of Unit I is marked by high $\mathrm{L}^{*}, \mathrm{a}^{*}$, and $\mathrm{b}^{*}$ values (averaging $62,5.1$, and 16 , respectively); this high is related to the presence of clay in the upper part of this succession. $L^{*}$ and $b^{*}$ values increase around the middle of Subunit IVa ( 96-102 m CSF). These increases in $L^{*}, a^{*}$, and $b^{*}$ are clearly responding to lithology, where carbonaterich sections are light brown-gray and radiolarianrich sections are darker brown.

\section{Stratigraphic correlation and composite section}

Special Task Multisensor Logger (STMSL) data were collected at $5 \mathrm{~cm}$ intervals from Holes U1332B and U1332C and compared to the WRMSL data obtained from Hole U1332A. In this way we monitored drilling in Holes U1332B and U1332C in real time to recover and construct a stratigraphically complete composite section. Several intervals between Holes U1332A and U1332B did not overlap sufficiently to cover gaps between cores. Thus, coring of Hole U1332C was designed to cover the missing intervals, as well as to provide additional material for high-resolution studies. Coring in Hole U1332C was successful at covering gaps between cores in Holes U1332A and U1332B to a depth of $\sim 125.46 \mathrm{~m}$ CSF (140.38 m CCSF-A) (Fig. F34). Below 140 m CCSF-A, recovery was poor and it was not possible to correlate features in the track data between different holes. The position of Core 320-U1332C-10H was designed to cover a gap in the composite section between the bottom of Core 320-U1332A-9H and the undisturbed part of Core 320-U1332B-10H ( 83 m CCSF-A) (Fig. F34). However, the coring line parted during retrieval of the core and the impact of the subsequent fall and fishing operations left the physical properties of the entire core unsuitable for stratigraphic correlation. The correlation between the three holes for the chosen parameters was adequate to good and, in some depth intervals, excellent. The gaps between successive cores in any of the holes are on the order of 1 to $2 \mathrm{~m}$, with a maximum of $3.5 \mathrm{~m}$ between Cores 320$\mathrm{U} 1332 \mathrm{~A}-13 \mathrm{H}$ and $14 \mathrm{H}$.

The correlation was refined once magnetic susceptibility and GRA density were available at $2.5 \mathrm{~cm}$ resolution from the WRMSL and NGR and color reflectance data were available from the NGR track and the SHMSL (see "Physical properties"). Magnetic susceptibility and GRA density proved most useful for correlating between holes at Site U1332. Features in the magnetic susceptibility are well aligned between Holes U1332A-U1332C to 140 m CCSF-A, although the section below $100 \mathrm{~m}$ CCSF-A is difficult to correlate because of the scarcity of characteristic features (Fig. F34). Offsets and composite depths are listed in Table T33. Strong winds and swells caused 3 $m$ heave, which had a negative effect on the quality of the APC cores, especially on the core tops (see "Paleomagnetism;" Table T11). Chert and porcellanite layers in lithologic Unit IV (see "Lithostratigraphy") below $\sim 130 \mathrm{~m}$ CSF were the main reason for poor core recovery in this interval.

Following construction of the composite depth section for Site U1332, a single spliced record was as- 
sembled for the aligned cores to 140 m CCSF-A with a gap at 83 m CCSF-A (Fig. F34). Detailed correlation and comparison with the Site 1220 magnetic susceptibility record (Shipboard Scientific Party, 2002b) suggests that the gap spans $<50 \mathrm{~cm}$, indicating that only a very small part of the section is missing. The sections of core used for the splice are identified in Table T34 and displayed in Figure F34. The spliced composite section consists of almost equal proportions from all three holes (Fig. F34).

Biostratigraphic and magnetostratigraphic evidence (see "Biostratigraphy" and "Paleomagnetism") suggests repetition of nannofossil Zones NP21 and NP22 (and Chrons C12r and C13n) in the early Oligocene sediments. Superposition of the duplicated section and comparison with the Site 1220 susceptibility record (Shipboard Scientific Party, 2002b) (Fig. F35) shows very good agreement and supports the hypothesis of a duplication of this sequence over a 5-7 $\mathrm{m}$ interval in all three drilled holes. Hole U1332A is duplicated between 73.2 and $78.1 \mathrm{~m}$ CCSF-A, Hole U1332B between 71.2 and $77.3 \mathrm{~m}$ CCSF-A, and Hole U1332C between 68.2 and $75.7 \mathrm{~m}$ CCSF-A (see also corresponding intervals in Fig. F34B).

We avoided intervals with significant disturbance or distortion and intervals where whole-round samples for interstitial water chemistry and microbiology were taken (see "Paleomagnetism;" Table T11). The Site U1332 splice can be used as a sampling guide to recover a single sedimentary sequence between 0 and $140 \mathrm{~m}$ CCSF-A, although it is advisable to overlap a few decimeters from different holes when sampling to accommodate anticipated ongoing development of the depth scale. Stretching and compression of sedimentary features in aligned cores indicates distortion of the cored sequence. Because much of the distortion occurs within individual cores on depth scales of $<9 \mathrm{~m}$, it was not possible to align every single feature in the magnetic susceptibility, GRA, NGR, and color reflectance records. However, at crossover points along the splice (Table T34), care was taken to align highly identifiable features from cores in each hole.

A growth factor of 1.10 is calculated by linear regression for all holes at Site U1332, indicating a 10\% increase in CCSF-A relative to CSF depth (Fig. F36). We used this value to calculate the CCSF-B (see "Corrected core composite depth scale" in the "Methods" chapter) depth presented in Table T33 to aid in the calculation of mass accumulation rates.

\section{Sedimentation rates}

All the principal biostratigraphies, plus a set of $\sim 72$ paleomagnetic reversals, are defined in Holes
U1332A-U1332C (Table T35; see "Biostratigraphy" and "Paleomagnetism") and were used in establishing age control (Fig. F11). Only the paleomagnetic reversals are used to calculate the average linear sedimentation rates (LSRs) for Site U1332 as depicted in Figure F11 using the CCSF-B depth scale.

Based on a simple linear interpolation from the sediment surface (assumed to be zero age) and the onset of Chron C2An.3n (Table T35), the clays of lithologic Unit I (see "Lithostratigraphy") have an LSR of $2.7 \mathrm{~m} / \mathrm{m} . \mathrm{y}$.

The LSR at Site U1332 in the radiolarian and nannofossil oozes of lithologic Units II and III decreases from $\sim 7 \mathrm{~m} / \mathrm{m}$.y. in the middle Eocene to $4.5 \mathrm{~m} / \mathrm{m}$.y. in the late Eocene to early Oligocene and to $\sim 3 \mathrm{~m} /$ m.y. in the remainder of the section. A hiatus is present between $\sim 20.4$ and $3.6 \mathrm{Ma}$ (Fig. F11) at the location of the major susceptibility peak at 11-13 m CCSF-A in Figure F34A.

\section{Downhole measurements}

\section{Logging operations}

Downhole logging measurements in Hole U1332A were made after completion of $\mathrm{APC} / \mathrm{XCB}$ coring to a total depth of $152.9 \mathrm{~m}$ DSF. In preparation for logging, the hole was flushed with a $65 \mathrm{bbl}$ sweep of high viscosity mud and the go-devil was dropped to open the lockable flapper valve. The hole was then displaced with $80 \mathrm{bbl}$ of mud, and the bit was pulled up to $\sim 80 \mathrm{~m}$ DSF. No tight spots were encountered while raising the drill string. The deployment of two tool strings (modified triple combo and FMS-sonic) was planned for Hole U1332A.

On 24 March 2009, the modified triple combo tool string (magnetic susceptibility, density, and NGR) was lowered and logged down to $\sim 150 \mathrm{~m}$ WSF, almost to the bottom of the hole. Two upward logging passes were made up to the base of the pipe (Fig. F37). The tools provided continuous and good quality log data, but they are affected by ship heave (typically $2 \mathrm{~m}$ peak to peak) because the wireline heave compensator (WHC) was not working. The borehole diameter ranged from $\sim 33 \mathrm{~cm}$ (13 inches) near the base of the hole to $>50 \mathrm{~cm}$ (20 inches) above $127 \mathrm{~m}$ WMSF. Logging results gave information on the porcellanite-bearing sediment interval below $136 \mathrm{~m}$ WMSF that was only partially recovered in the cores.

At the end of the second upward pass we encountered difficulties when attempting to pull the tool string back into the pipe. Four attempts were made to enter the pipe, and each time increasing cable tension indicated that the head of the tool was obstructed at the base of the pipe, likely near the LFV. 
The pipe was raised $5 \mathrm{~m}$ and then another $5 \mathrm{~m}$, and four more unsuccessful attempts were made to enter the pipe. The pipe was rotated, and then seawater was pumped down to attempt to remove any obstructions and push open the LFV. During this procedure communications with the tool string were partially lost, and shortly after that the wireline lost $\sim 800 \mathrm{lb}$ of weight, corresponding to the weight of the tool string. At $0600 \mathrm{~h}$ (HST) on $25 \mathrm{March}$, the wireline was retrieved and it was confirmed that the tool string was severed from the wireline. The end of the wireline had suffered an apparently clean cut, making the most likely culprit the LFV. Fishing attempts were made to retrieve the tool string over $\sim 18$ $\mathrm{h}$, using two kinds of grapple on the end of an APC core barrel; however, these were unsuccessful. Hole U1332A was cemented and abandoned on 26 March.

\section{Logging units}

Hole U1332A was divided into three units on the basis of the logs (Fig. F38).

\section{Logging Unit 1: base of drill pipe to $136 \mathrm{~m}$ WMSF}

Unit 1 is characterized by mostly low gamma ray values (between 3 and 9 gAPI), low density values varying between 1.25 and $1.5 \mathrm{~g} / \mathrm{cm}^{3}$, and low magnetic susceptibility. Unit 1 has been divided into seven subunits $(1 \mathrm{~A}-1 \mathrm{G})$. Subunits $1 \mathrm{~A}, 1 \mathrm{C}$, and $1 \mathrm{E}$ are characterized by low gamma, photoelectric effect (PEF), and density, with slightly higher magnetic susceptibility and electrical conductivity than the surrounding subunits. The low bulk density $\left(\sim 1.3 \mathrm{~g} / \mathrm{cm}^{3}\right)$ of these subunits is consistent with the lithostratigraphy of high-porosity radiolarian ooze (radiolarian opal has a density of $\sim 2.15 \mathrm{~g} / \mathrm{cm}^{3}$, whereas calcite and most clays have densities around $2.7 \mathrm{~g} / \mathrm{cm}^{3}$ ). In comparison, Subunits $1 \mathrm{~B}$ and $1 \mathrm{D}$ have higher density and PEF, most likely indicative of higher carbonate content. Electrical conductivity is lower, indicating lower porosity, and magnetic susceptibility is also low, indicating probably lower terrigenous content than in the radiolarian oozes.

Subunit $1 \mathrm{~F}$ is characterized by high density $(\sim 1.8 \mathrm{~g} /$ $\left.\mathrm{cm}^{3}\right)$ and high PEF ( $\sim 3$ capture units), consistent with the recovered porcellanite in this zone (see "Lithostratigraphy"). Magnetic susceptibility is higher in Subunit 1F, and conductivity is low.

The lowermost subunit (1G) includes a peak in total gamma ray to 45 gAPI units (Fig. F39), which is mostly made up of contributions from uranium and potassium. Its origin is unclear at the moment. It seems likely that an increased proportion of clays would account for the potassium but not the uranium.

\section{Logging Unit 2: 136-146 m WMSF}

Unit 2 is characterized by a series of peaks reaching densities of $2.0 \mathrm{~g} / \mathrm{cm}^{3}$ and lower electrical conductivity, indicating harder and less porous sediment overall (Fig. F38). PEF values higher than 4 capture units indicate that high PEF elements such as Mn or Fe may also be present in addition to calcium carbonate $(\mathrm{PEF}=\sim 5)$. The corresponding lithostratigraphy only partially recovered in this interval, however, is a mixture of radiolarian oozes and porcellanites.

\section{Logging Unit 3: 146-151 m WMSF}

The only log data for Unit 3 is magnetic susceptibility and conductivity measured at the base of the tool string. Magnetic susceptibility sharply increases to higher values at the top of the unit. These are identified in the lithostratigraphy as dark brown zeolitic clays.

\section{Heat flow}

Seven APCT-3 temperature measurements in Holes $\mathrm{U} 1332 \mathrm{~B}$ and $\mathrm{U} 1332 \mathrm{C}$ ranged from $1.77^{\circ} \mathrm{C}$ at $11.6 \mathrm{~m}$ to $9.11^{\circ} \mathrm{C}$ at $100.6 \mathrm{~m}$ (Table T36), giving a geothermal gradient of $75.0^{\circ} \mathrm{C} / \mathrm{km}$ (Fig. F40). The seafloor temperature was $1.46^{\circ} \mathrm{C}$, based on the average temperature minima of the eight temperature profiles (one APCT-3 deployment, on Core 320-U1332B-5H, did not result in a valid in situ temperature). Thermal conductivity under in situ conditions was estimated from laboratory-determined thermal conductivity using the method of Hyndman et al. (1974) (see "Physical properties" in the "Methods" chapter). The calculated in situ values are within $2.2 \%$ of the measured laboratory values. Thermal resistance was then calculated by cumulatively adding the inverse of the in situ thermal conductivity values over depth intervals downhole (Fig. F40). Heat flow was obtained from the linear fit between temperature and thermal resistance (Fig. F40) (Pribnow et al., 2000). The heat flow estimate for Site 1332 is 70.7 $\mathrm{mW} / \mathrm{m}^{2}$, which is similar to heat flow values from nearby Sites 1218 and 1219.

\section{References}

Adkins, J.F., and Schrag, D.P., 2003. Reconstructing Last Glacial Maximum bottom water salinities from deep-sea sediment pore fluid profiles. Earth Planet Sci. Lett., 216:109-123. doi:10.1016/S0012-821X(03)00502-8

Amante, C., and Eakins, B.W., 2008. ETOPO1 1 Arc-Minute Global Relief Model: Procedures, Data Sources and Analysis: Washington, DC (DOC/NOAA/NESDIS/NGDC).

Barron, J.A., 1985. Late Eocene to Holocene diatom biostratigraphy of the equatorial Pacific Ocean, Deep Sea Drilling Project Leg 85. In Mayer, L., Theyer, F., Thomas, 
E., et al., Init. Repts. DSDP, 85: Washington, DC (U.S. Govt. Printing Office), 413-456. doi:10.2973/ dsdp.proc.85.108.1985

Barron, J.A. 2006. Diatom biochronology for the early Miocene of the equatorial Pacific. Stratigraphy, 2(4):281-30.

Barron, J.A., Fourtanier, E., and Bohaty, S.M., 2004. Oligocene and earliest Miocene diatom biostratigraphy of ODP Leg 199 Site 1220, equatorial Pacific. In Wilson, P.A., Lyle, M., Janecek, T.R., and Firth, J.V. (Eds.), Proc. ODP, Sci. Results, 199: College Station (Ocean Drilling Program), 1-25. doi:10.2973/

odp.proc.sr.199.204.2004

Busch, W.H., Vanden Berg, M.D., and Masau, P.E., 2006. Velocity and density of Paleogene equatorial sediments: variation with sediment composition. In Wilson, P.A., Lyle, M., and Firth, J.V. (Eds.), Proc. ODP, Sci. Results, 199: College Station, TX (Ocean Drilling Program), 131. doi:10.2973/odp.proc.sr.199.226.2006

Cande, S.C., and Kent, D.V., 1995. Revised calibration of the geomagnetic polarity timescale for the Late Cretaceous and Cenozoic. J. Geophys. Res., 100(B4):60936095. doi:10.1029/94JB03098

Cande, S.C., LaBrecque, J.L., Larson, R.L., Pitmann, W.C., III, Golovchenko, X., and Haxby, W.F., 1989. Magnetic Lineations of the World's Ocean Basins. AAPG Map Ser., 13.

Coxall, H.K., Wilson, P.A., Pälike, H., Lear, C.H., and Backman, J., 2005. Rapid stepwise onset of Antarctic glaciation and deeper calcite compensation in the Pacific Ocean. Nature (London, U. K.), 433(7021):53-57. doi:10.1038/nature03135

Engebretson, D.C., Cox, A., and Gordon, R.G., 1985. Relative Motions between Oceanic and Continental Plates in the Pacific Basin. Spec. Pap.-Geol. Soc. Am., 206.

Hyndman, R.D., Erickson, A.J., and Von Herzen, R.P., 1974. Geothermal measurements on DSDP Leg 26. In Davies, T.A., Luyendyk, B.P., et al., Init. Repts. DSDP, 26: Washington, DC (U.S. Govt. Printing Office), 451-463. doi:10.2973/dsdp.proc.26.113.1974

Knappenberger, M., 2000. Sedimentation rates and Pacific plate motion calculated using seismic cross sections of the Neogene equatorial sediment bulge [M.Sc. thesis]. Boise State Univ., Idaho.

Koppers, A.A.P., Phipps Morgan, J., Morgan, J.W., and Staudigel, H., 2001. Testing the fixed hotspot hypothesis using ${ }^{40} \mathrm{Ar} /{ }^{39} \mathrm{Ar}$ age progressions along seamount trails. Earth Planet. Sci. Lett., 185(3-4):237-252. doi:10.1016/ S0012-821X(00)00387-3

Lyle, M., 2003. Neogene carbonate burial in the Pacific Ocean. Paleoceanography, 18(3):1059. doi:10.1029/ 2002PA000777

Lyle, M., Liberty, L., Moore, T.C., Jr., and Rea, D.K., 2002. Development of a seismic stratigraphy for the Paleogene sedimentary section, central tropical Pacific Ocean. In Lyle, M., Wilson, P.A., Janecek, T.R., et al., Proc. ODP, Init. Repts., 199: College Station, TX (Ocean Drilling Program), 1-21. doi:10.2973/ odp.proc.ir.199.104.2002
Lyle, M., Wilson, P.A., Janecek, T.R., et al., 2002. Proc. ODP, Init. Repts., 199: College Station, TX (Ocean Drilling Program). doi:10.2973/odp.proc.ir.199.2002

Lyle, M., Olivarez Lyle, A., Backman, J., and Tripati, A., 2005. Biogenic sedimentation in the Eocene equatorial Pacific - the stuttering greenhouse and Eocene carbonate compensation depth. In Lyle, M., Wilson, P.A., Janecek, T.R., et al., Proc. ODP, Init. Repts., 199: College Station, TX (Ocean Drilling Program), 1-35. doi:10.2973/odp.proc.sr.199.219.2005

Lyle, M.W., Pälike, H., Moore, T.C., Mitchell, N., and Backman, J., 2006. Summary Report of R/V Roger Revelle Site Survey AMAT03 to the IODP Environmental Protection and Safety Panel (EPSP) in Support for Proposal IODP626: Southampton, U.K. (Univ. Southampton). http:// eprints.soton.ac.uk/45921/

Lowenstein, T.K., and Demicco, R.V., 2007. Elevated Eocene atmospheric $\mathrm{CO}_{2}$ and subsequent decline. Science, 313(5795):1928. doi:10.1126/science.1129555

Moore, T.C., Jr., 2008. Biogenic silica and chert in the Pacific Ocean. Geology, 36(12):975-978. doi:10.1130/ G25057A.1

Müller, R.D., Roest, W.R., Royer, J.-Y., Gahagan, L.M., and Sclater, J.G., 1997. Digital isochrons of the world's ocean floor. J. Geophys. Res., 102(B2):3211-3214. doi:10.1029/96JB01781

Nomura, R., and Takata, H., 2005. Data report: Paleocene/ Eocene benthic foraminifers, ODP Leg 199 Sites 1215, 1220, and 1221, equatorial central Pacific Ocean. In Wilson, P.A., Lyle, M., and Firth, J.V. (Eds.), Proc. ODP, Sci. Results, 199: College Station, TX (Ocean Drilling Program), 1-34. doi:10.2973/ odp.proc.sr.199.223.2005

Nuñes, F., and Norris, R.D., 2006. Abrupt reversal in ocean overturning during the Palaeocene/Eocene warm period. Nature (London, U. K.), 439(7072):60-63. doi:10.1038/nature04386

Olsson, R.K., Hemleben, C., and Pearson, P.N., 2006. Taxonomy, biostratigraphy, and phylogeny of Eocene Detoglobigerina. In Pearson, P.N., Olsson, R.K., Huber, B.T., Hemleben, C., and Berggren, W.A. (Eds.), Atlas of Eocene Planktonic Foraminifera. Spec. Publ.-Cushman Found. Foraminiferal Res., 41:401-412.

Pälike, H., Lyle, M.W., Ahagon, N., Raffi, I., Gamage, K., and Zarikian, C.A., 2008. Pacific equatorial age transect. IODP Sci. Prosp., 320/321. doi:10.2204/ iodp.sp.320321.2008

Pälike, H., Norris, R.D., Herrle, J.O., Wilson, P.A., Coxall, H.K., Lear, C.H., Shackleton, N.J., Tripati, A.K., and Wade, B.S., 2006. The heartbeat of the Oligocene climate system. Science, 314(5807):1894-1898. doi:10.1126/science.1133822

Petronotis, K.E., 1991. Paleomagnetic studies of the skewness of Pacific plate marine magnetic anomalies 2532R: implications for anomalous skewness and the motion of the Pacific plate and hotspots [Ph.D. thesis]. Northwestern Univ., Evanston, IL.

Petronotis, K.E., Gordon, R.G., and Acton, G.D., 1994. A 57 Ma Pacific plate paleomagnetic pole determined from a skewness analysis of crossings of marine mag- 
netic anomaly 25r. Geophys. J. Int., 118(3):529-554. doi:10.1111/j.1365-246X.1994.tb03983.X

Pribnow, D.F.C., Kinoshita, M., and Stein, C.A., 2000. Thermal Data Collection and Heat Flow Recalculations for ODP Legs 101-180: Hanover, Germany (Inst. Joint Geosci. Res., Inst. Geowiss. Gemeinschaftsauf. [GGA]). http:// www-odp.tamu.edu/publications/heatflow/ ODPReprt.pdf

Raffi, I., Backman, J., and Pälike, H., 2005. Changes in calcareous nannofossil assemblages across the Paleocene/ Eocene transition from the paleo-equatorial Pacific Ocean. Palaeogeogr., Palaecoclimatol., Palaeoecol., 226(12):93-126. doi:10.1016/j.palaeo.2005.05.006

Rea, D.K., and Lyle, M.W., 2005. Paleogene calcite compensation depth in the eastern subtropical Pacific: answers and questions. Paleoceanography, 20(1):PA1012. doi:10.1029/2004PA001064

Sager, W.W., and Pringle, M.S., 1988. Mid-Cretaceous to early Tertiary apparent polar wander path of the Pacific plate. J. Geophys. Res., [Solid Earth], 93(B10):1175311771. doi:10.1029/JB093iB10p11753

Shackleton, N.J., Hall, M.A., Raffi, I., Tauxe, L., and Zachos, J., 2000. Astronomical calibration age for the Oligocene-Miocene boundary. Geology, 28(5):447-450. doi:10.1130/00917613(2000)28<447:ACAFTO >2.0.CO;2

Shipboard Scientific Party, 2002. Leg 199 summary. In Lyle, M., Wilson, P.A., Janecek, T.R., et al., Proc. ODP, Init. Repts., 199: College Station, TX (Ocean Drilling Program), 1-87. doi:10.2973/odp.proc.ir.199.101.2002

Shipboard Scientific Party, 2002. Site 1220. In Lyle, M., Wilson, P.A., Janecek, T.R., et al., Proc. ODP, Init. Repts.,
199: College Station, TX (Ocean Drilling Program), 192. doi:10.2973/odp.proc.ir.199.113.2002

Shipboard Scientific Party, 2003. Site 1223. In Stephen, R.A., Kasahara, J., Acton, G.D., et al., Proc. ODP, Init. Repts., 200: College Station, TX (Ocean Drilling Program), 1-159. doi:10.2973/odp.proc.ir.200.103.2003

Shipboard Scientific Party, 2004. Leg 208 summary. In Zachos, J.C., Kroon, D., Blum, P., et al., Proc. ODP, Init. Repts., 208: College Station, TX (Ocean Drilling Program), 1-112. doi:10.2973/odp.proc.ir.208.101.2004

Tanaka, H., 1999. Circular asymmetry of the paleomagnetic directions observed at low latitude volcanic sites. Earth, Planets Space, 51(12):1279-1286.

Thomas, E., 1985. Late Eocene to Recent deep-sea benthic foraminifers from the central equatorial Pacific Ocean. In Mayer, L., Theyer, F., Thomas, E., et al., Init. Repts. DSDP, 85: Washington, DC (U.S. Govt. Printing Office), 655-694. doi:10.2973/dsdp.proc.85.117.1985

van Andel, T.H., 1975. Mesozoic/Cenozoic calcite compensation depth and the global distribution of calcareous sediments. Earth Planet. Sci. Lett., 26(2):187-194. doi:10.1016/0012-821X(75)90086-2

van Morkhoven, F.P.C.M., Berggren, W.A., and Edwards, A.S., 1986. Cenozoic Cosmopolitan Deep-Water Benthic Foraminifera. Bull. Cent. Rech. Explor.-Prod. Elf-Aquitaine, Mem. 11.

Zachos, J., Pagani, M., Sloan, L., Thomas, E., and Billups, K., 2001. Trends, rhythms, and aberrations in global climate 65 Ma to present. Science, 292(5517):686-693. doi:10.1126/science.1059412

Publication: 30 October 2010 MS 320321-104 
Figure F1. A. ETOPO1 (Amante and Eakins, 2008) bathymetric overview map of Site U1332 and PEAT drilling locations, with previous ODP and DSDP sites. B. Swath map bathymetry for Site U1332 region from the AMAT03 site survey. Black labels $=$ seismic shotpoints, white labels $=$ bathymetric contours. Yellow line $=$ north-south trending survey line for Site U1332. F.Z. = fracture zone.
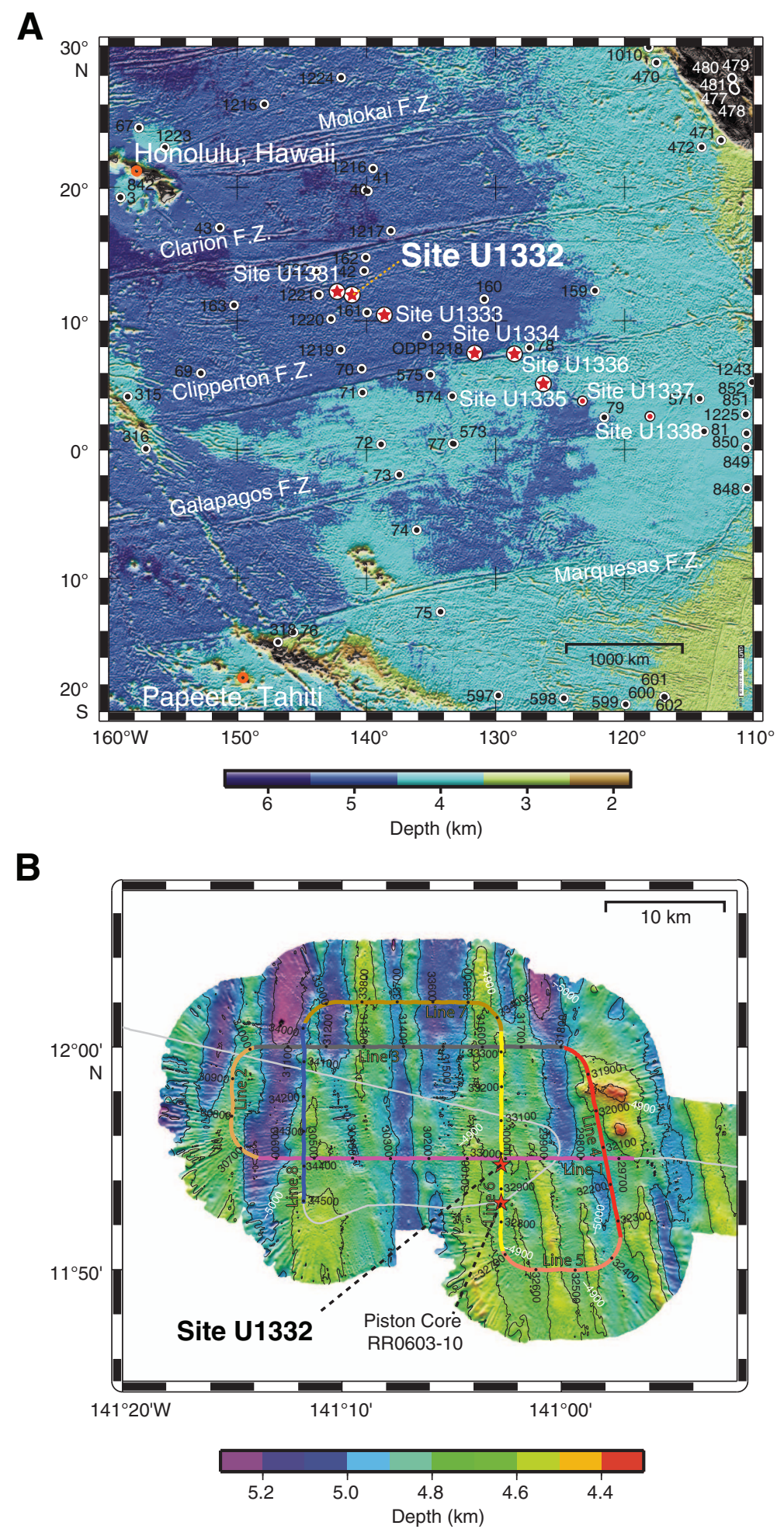
Figure F2. Seismic reflection profile PEAT-2C (Site U1332) Line 6 from the 48-channel seismic reflection survey, annotated in shotpoints (Lyle et al., 2006). Data are filtered, stacked, and migrated. Site was located where basal reflections appeared less strong to minimize possible cherts. Tentative conversion from two-way traveltime to depth uses velocity model of Busch et al. (2006). P2, P3 = seismic reflectors of Lyle et al., (2002). All times are Universal Time Coordinated (UTC). TD = total depth.

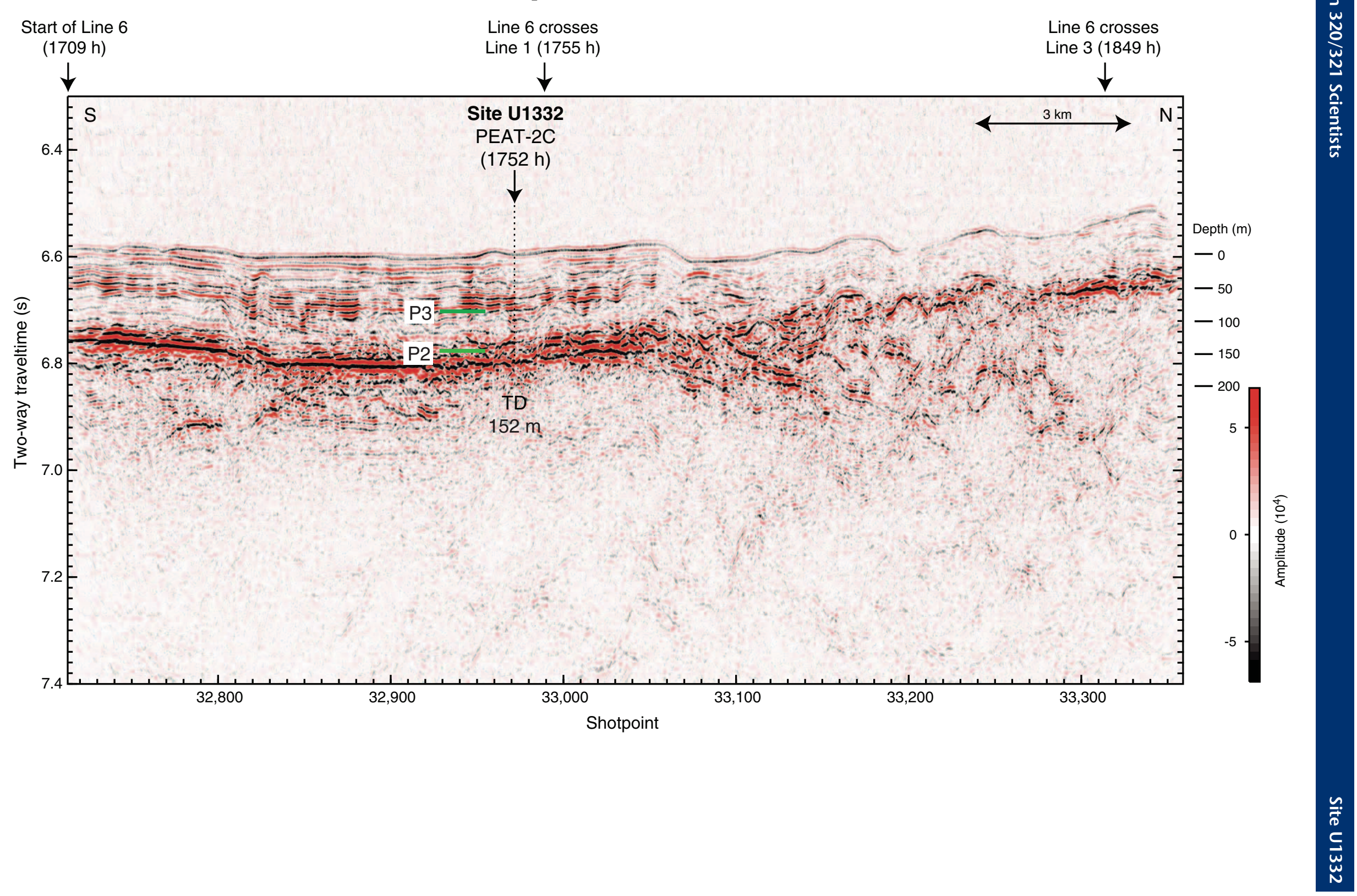


Figure F3. Lithologic summary, Site U1332. A $+5 \mathrm{~m}$ adjustment is added to the downhole logging magnetic susceptibility depths to convert from WMSF to CSF. $\mathrm{L}^{*}=$ reflectance value of sediment as defined in the LAB color model. Chron/Polarity: green wavy line = slump, red wavy line $=$ hiatus .

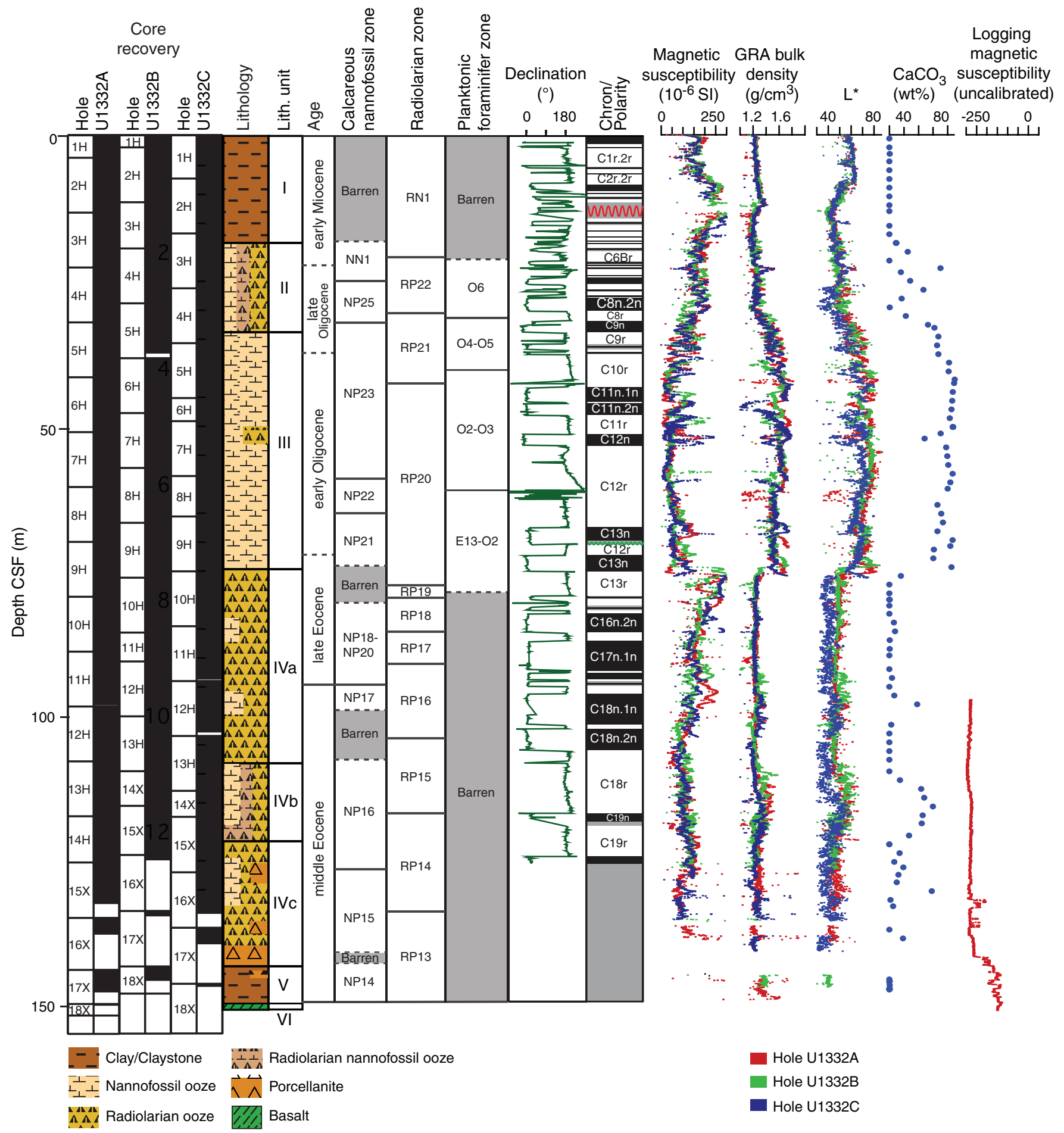


Figure F4. Site U1332 summary.
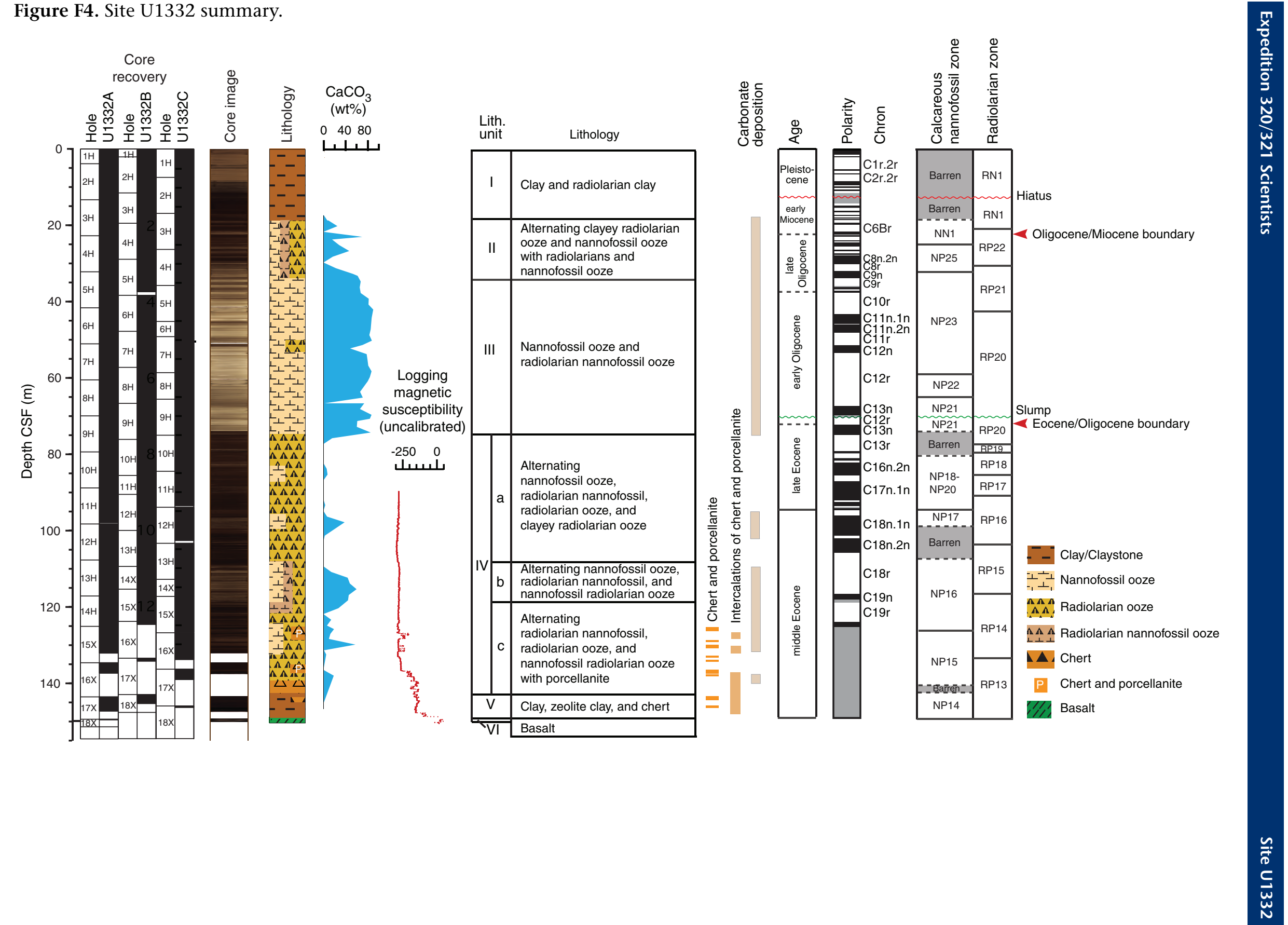
Figure F5. Smear slide photomicrographs of selected representative lithologies, Site U1332. Left image = planepolarized light, right image = cross-polarized light. A. Zeolite clay $($ Sample 320-U1332C-2H-3, $100 \mathrm{~cm})$. B. Nannofossil ooze (Sample 320-U1332C-5H-2, $14 \mathrm{~cm}$ ). C. Radiolarian nannofossil ooze with diatoms (Sample 320U1332C-8H-5, $18 \mathrm{~cm}$ ). D. Radiolarian ooze (Sample 320-U1332C-11H-4, $75 \mathrm{~cm}$ ).
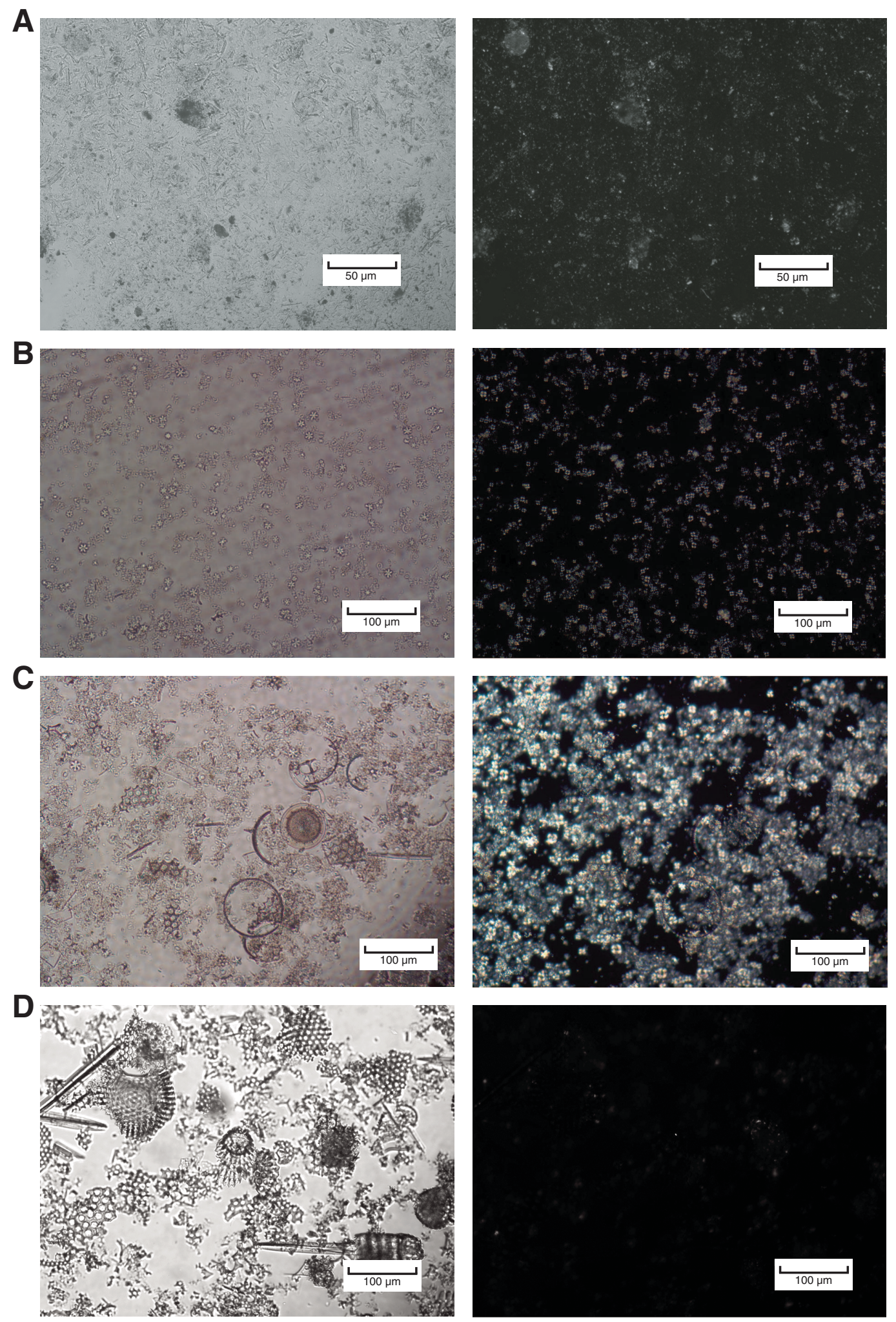
Figure F6. Thin section photomicrographs of porcellanites, Site U1332. Left image = plane-polarized light, right image $=$ cross-polarized light. A, B. Porcellanite with foraminifers and coarse basal layers (Sample 320-U1332A15X-2, 112-114 cm). C, D. Porcellanite with veins of recrystalized silica (Sample 320-U1332A-17X-1, 0-4 cm). Large radial crystals of chalcedony are visible in D.
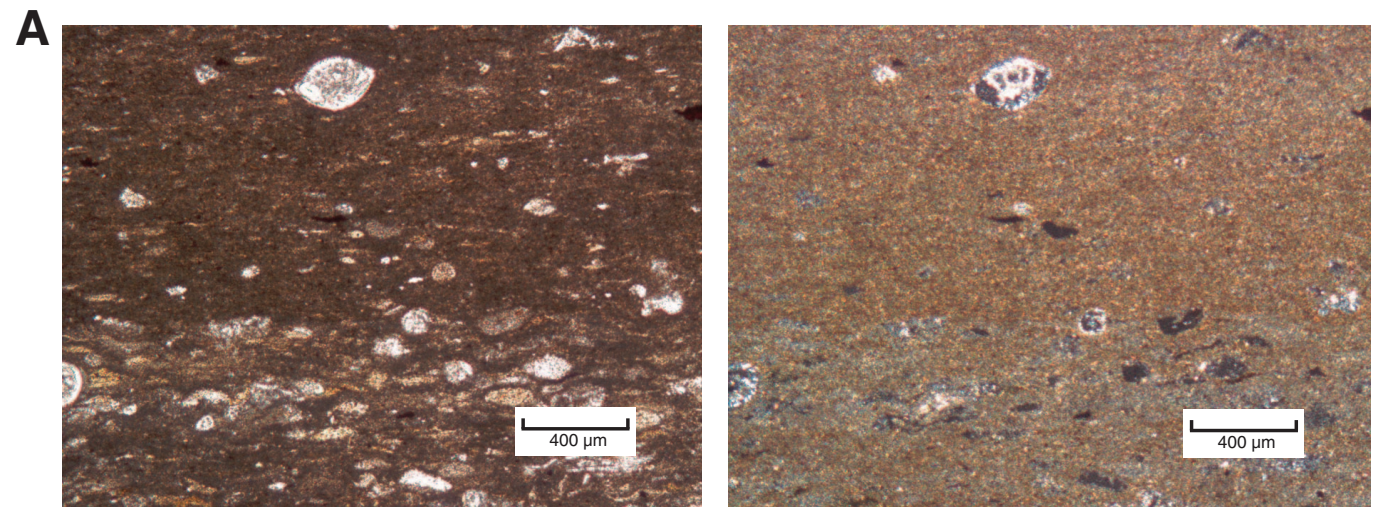

B
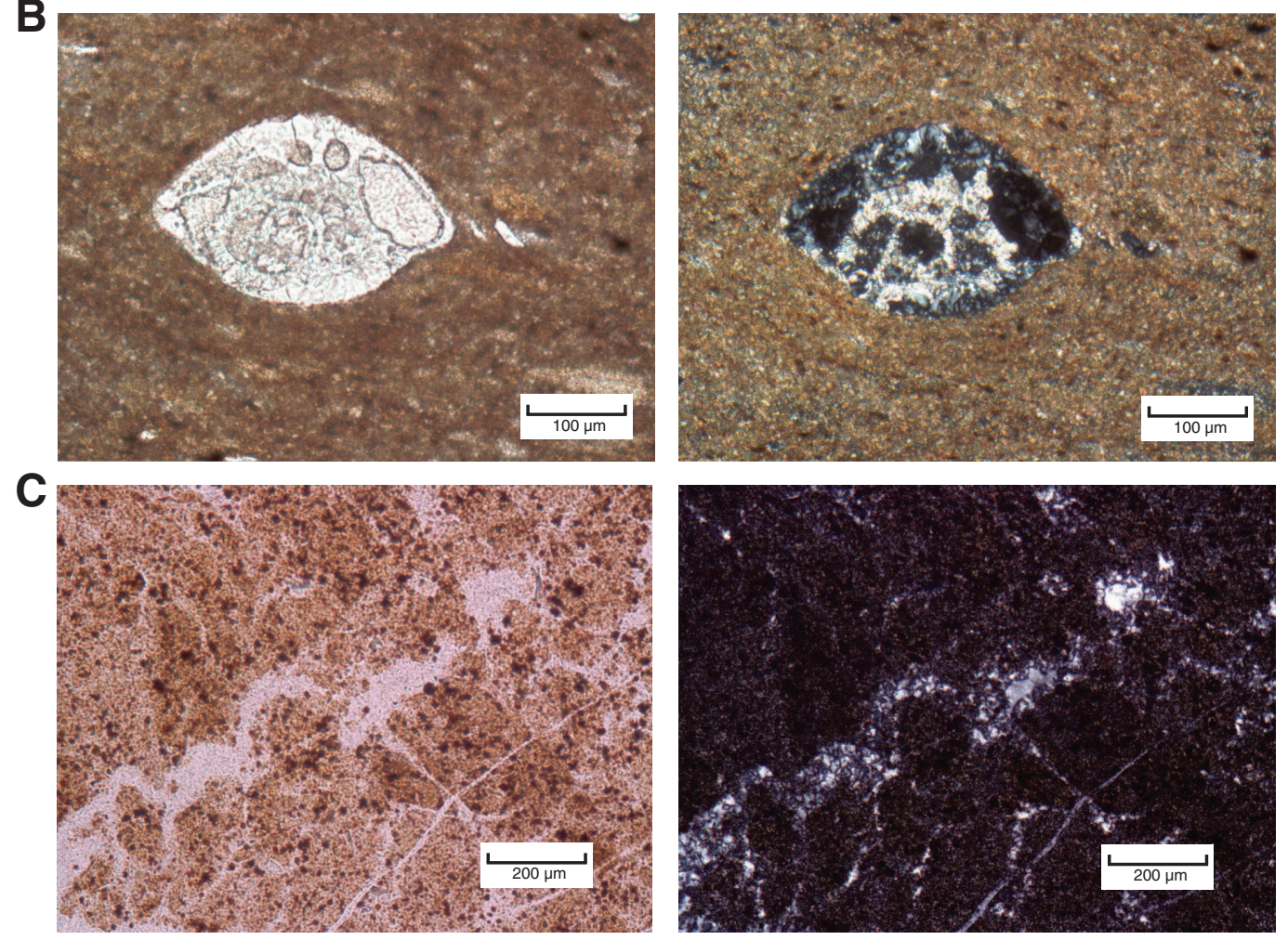

D
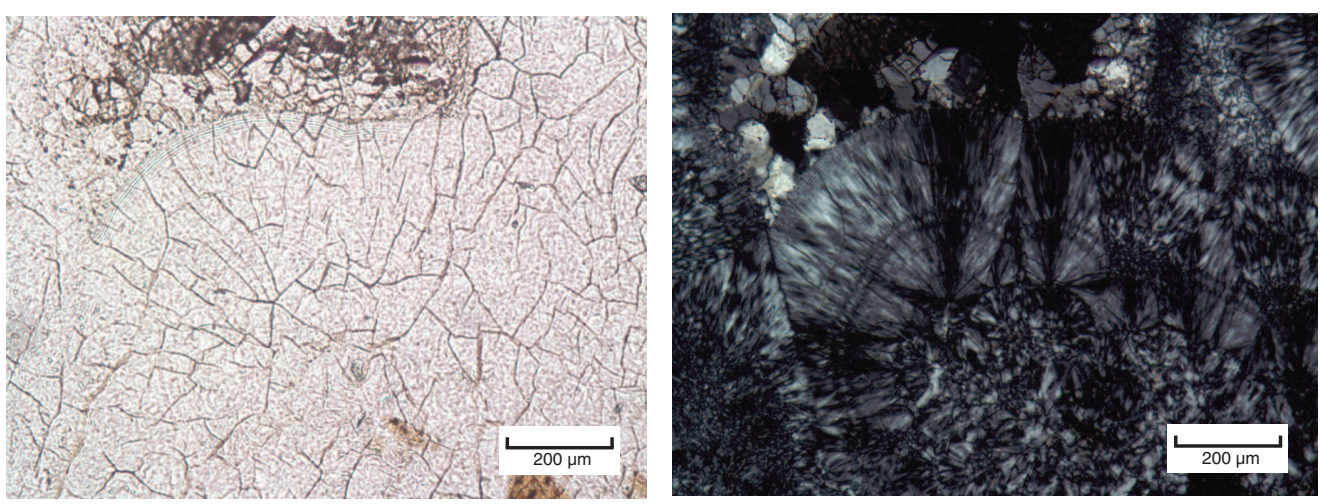
Figure F7. Thin section photomicrographs of basalt, Site U1332. Left image = plane-polarized light, right image $=$ cross-polarized light. A. Very fine grained sparsely plagioclase phyric basalt (fresh chilled margin = subhedral clinopyroxene, lath plagioclases, and glass in groundmass) (Sample 320-U1332A-18X-CC, 12-16 cm). B. Finegrained plagioclase phyric basalt (calcite vein and highly altered groundmass) (Sample 320-U1332A-18X-CC, $16-19 \mathrm{~cm})$.
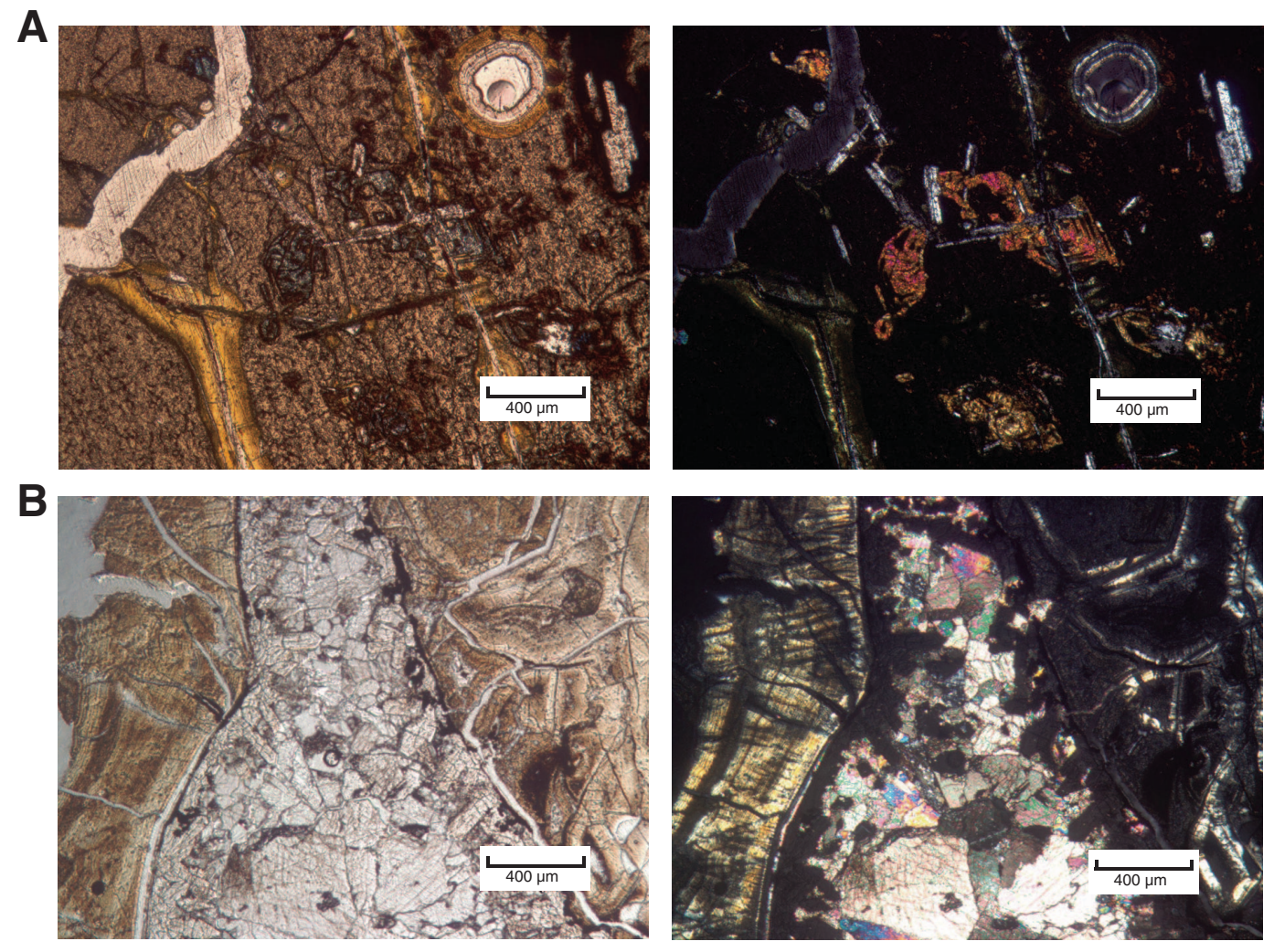
Figure F8. Line scan images, magnetic susceptibility, and lightness reflectance of Eocene-Oligocene transition. A. Hole U1332A. B. Hole U1332B. $\mathrm{L}^{*}=$ reflectance value of sediment as defined in the LAB color model.
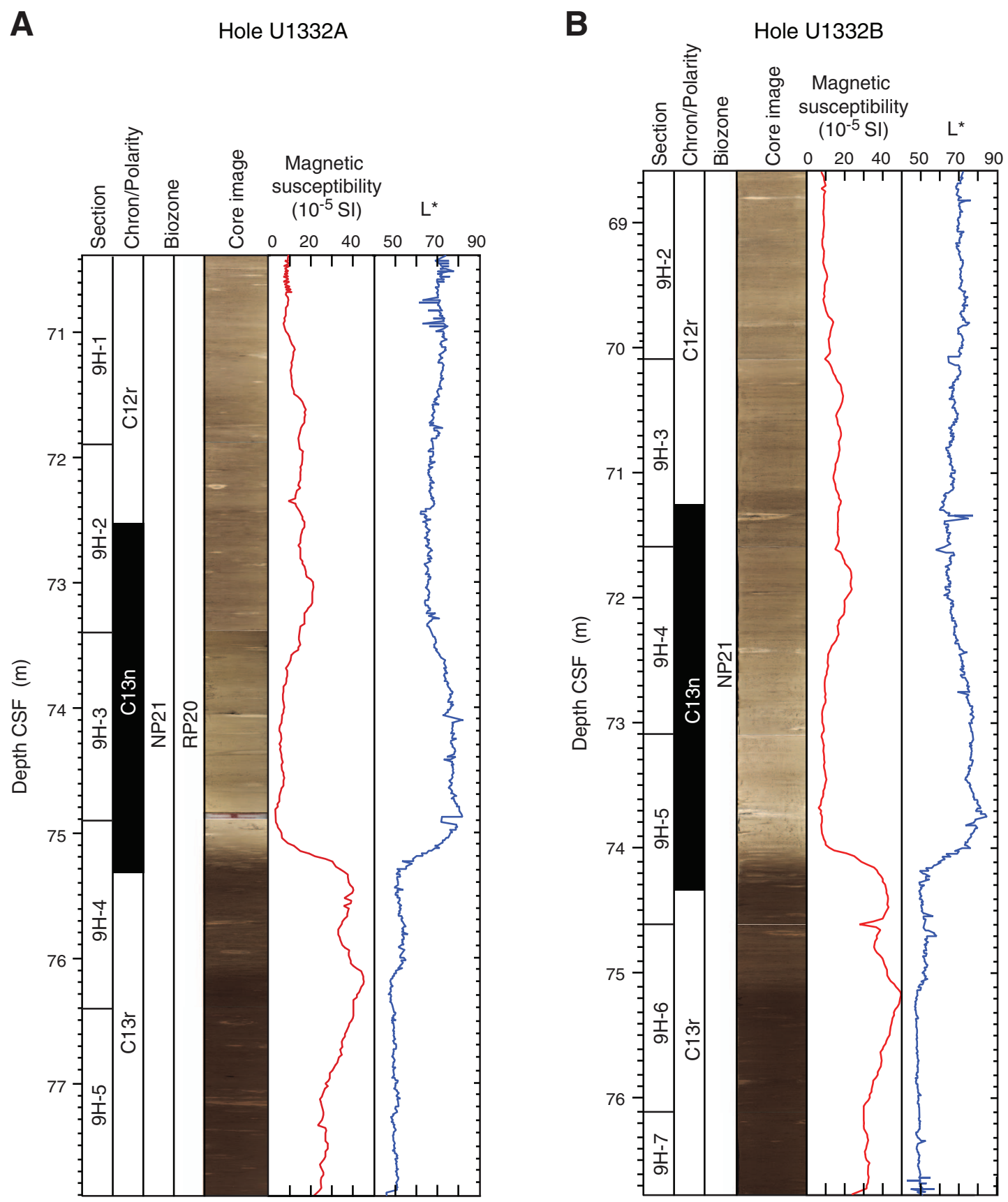
Figure F9. Line scan images of duplicated latest Eocene early Oligocene sequences with sharp contact (closeup images) recovered well above the Eocene-Oligocene transition. A. Sections 320-U1332B-8H-7 and 8H-CC. B. Section 320-U1332B-9H-2. Depths do not account for core gaps or core expansion (note overlap in depth between the bottom of Cores 320-U1332C-8H and 9H). In composite depth the sharp basal contact of the inferred slump or sliding shown in the close-up images falls $\sim 8 \mathrm{~m}$ above the Eocene-Oligocene transition (red arrows).

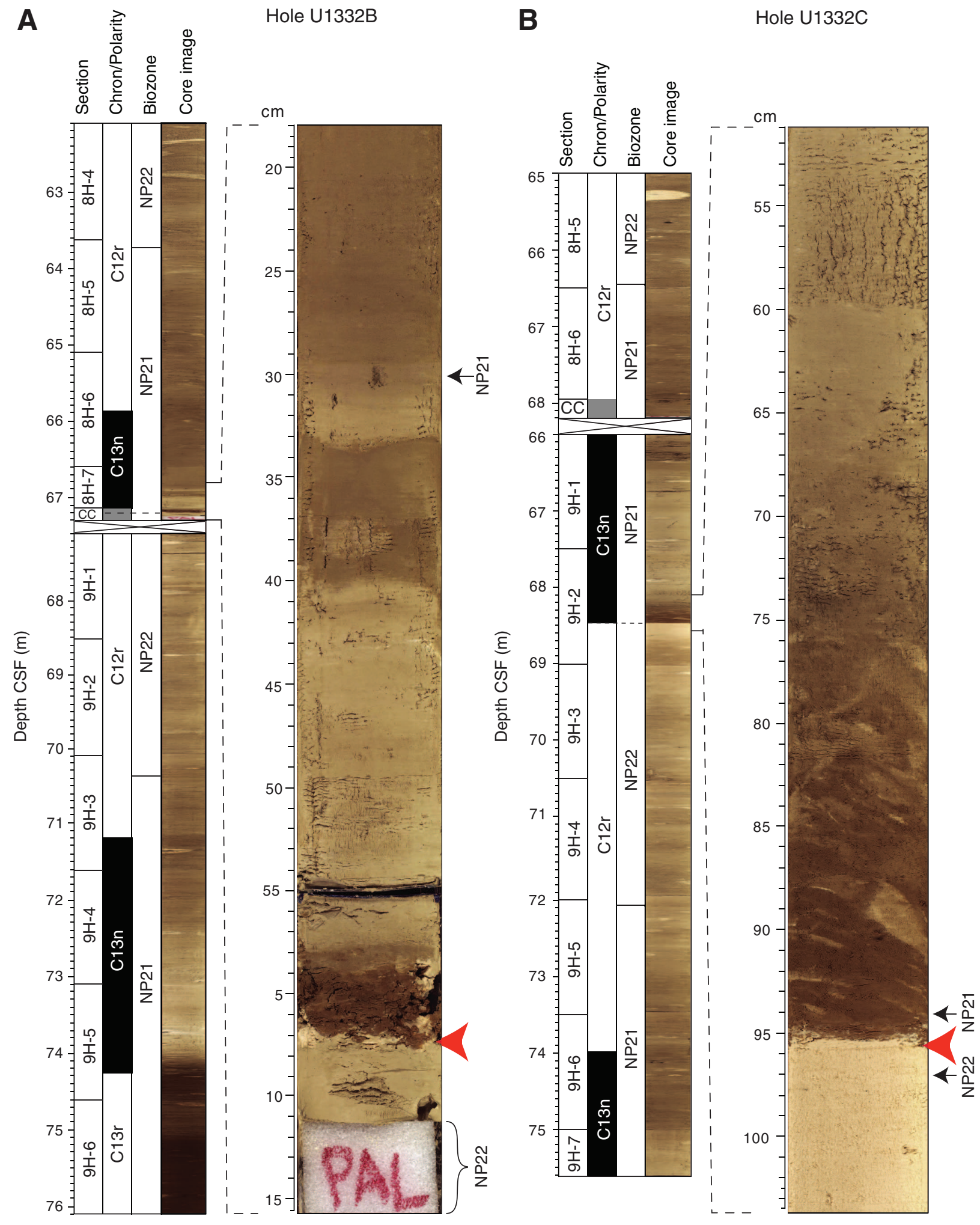


Figure F10. Integrated calcareous and siliceous microfossil biozonation, Site U1332. Calcareous microfossil zonation was limited by the presence of barren intervals; dashed zonal boundaries indicate stratigraphic extent of calcareous microfossil assemblages consistent with a particular zonal assignment.

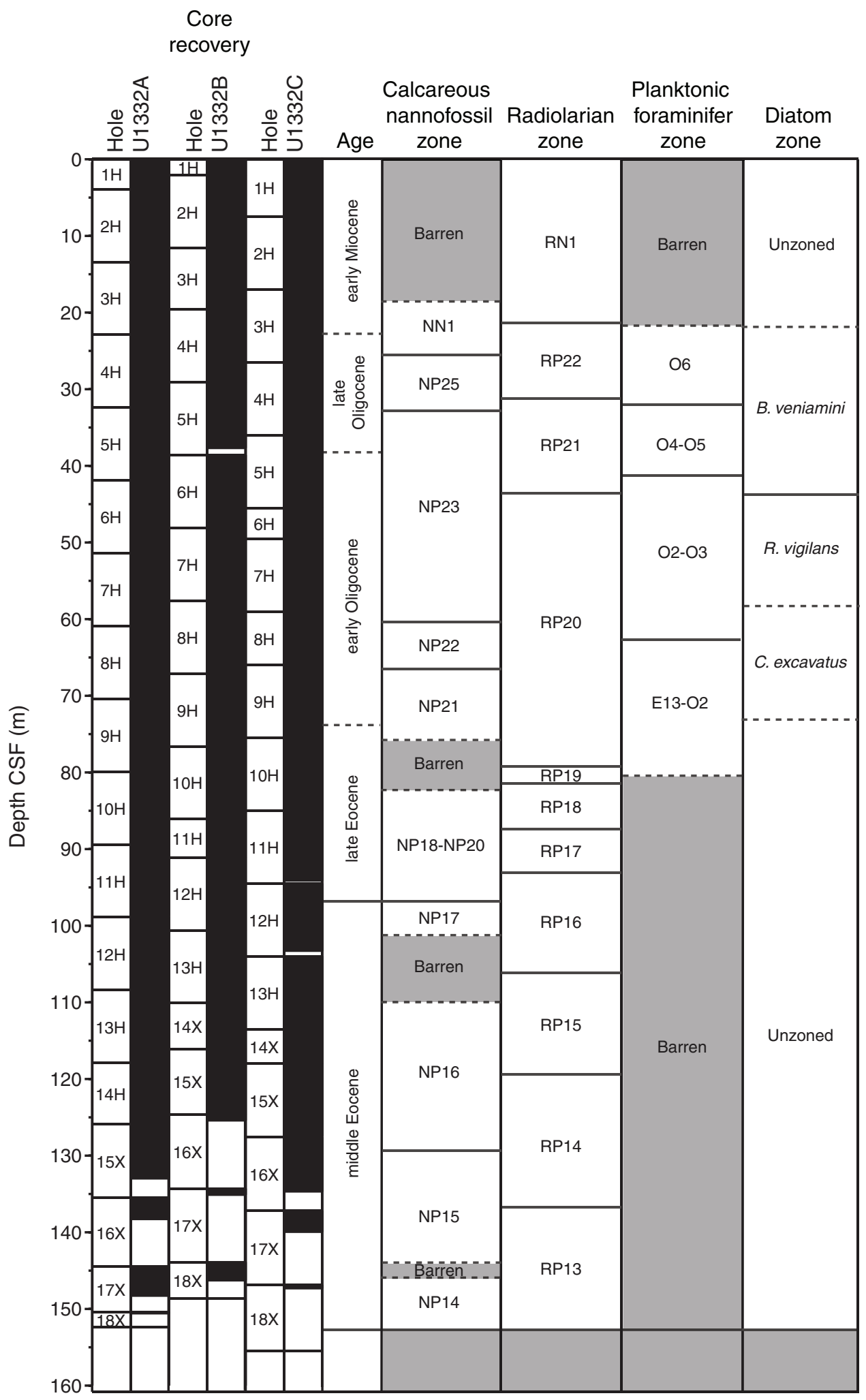


Figure F11. Linear sedimentation rates and chronostratigraphic markers, Site U1332.

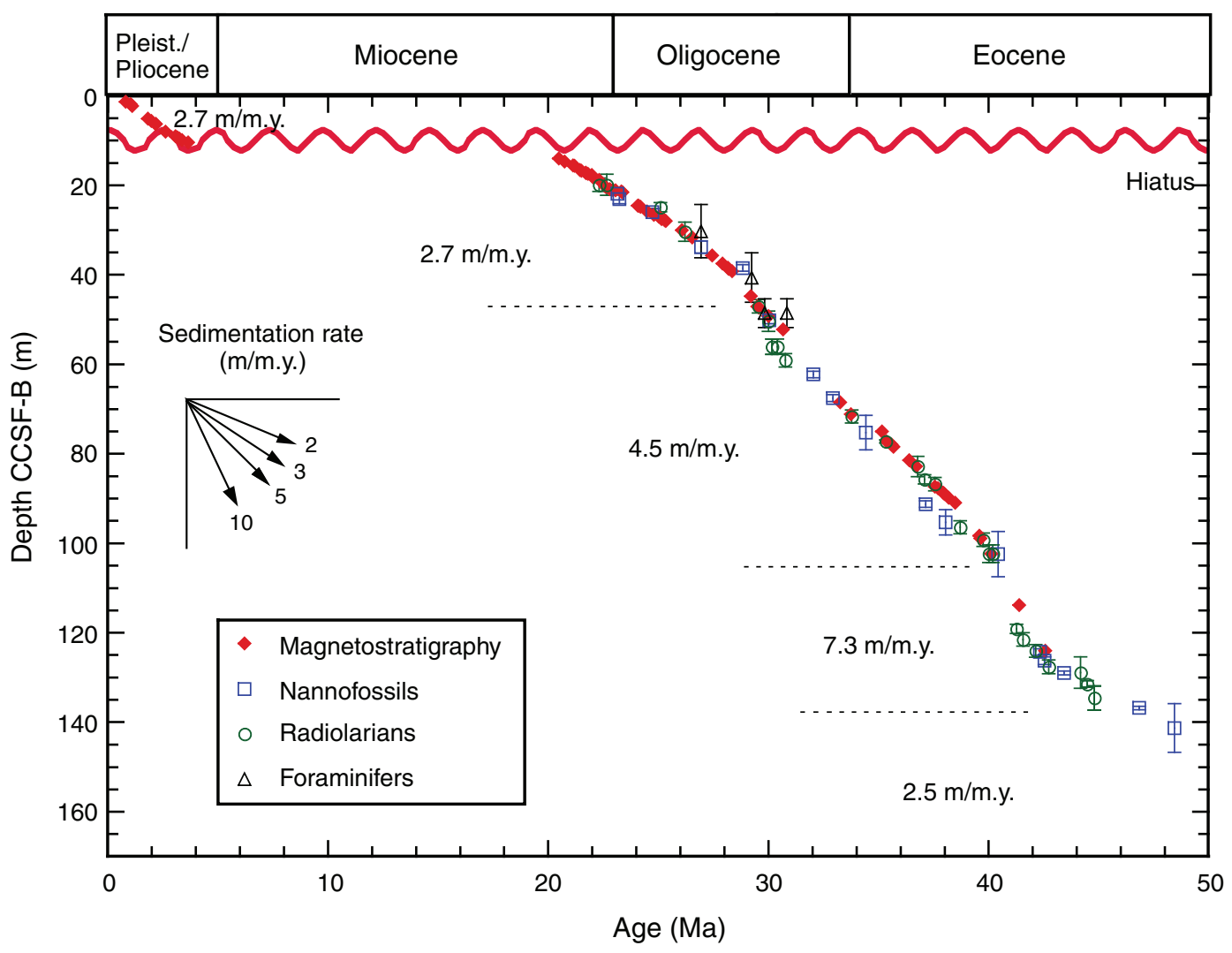


Figure F12. Summary of magnetic susceptibility and paleomagnetic results, Hole U1332A. Declinations are shown in sample coordinates (not reoriented to geographical coordinates). PCA = principal component analysis.

Hole U1332A

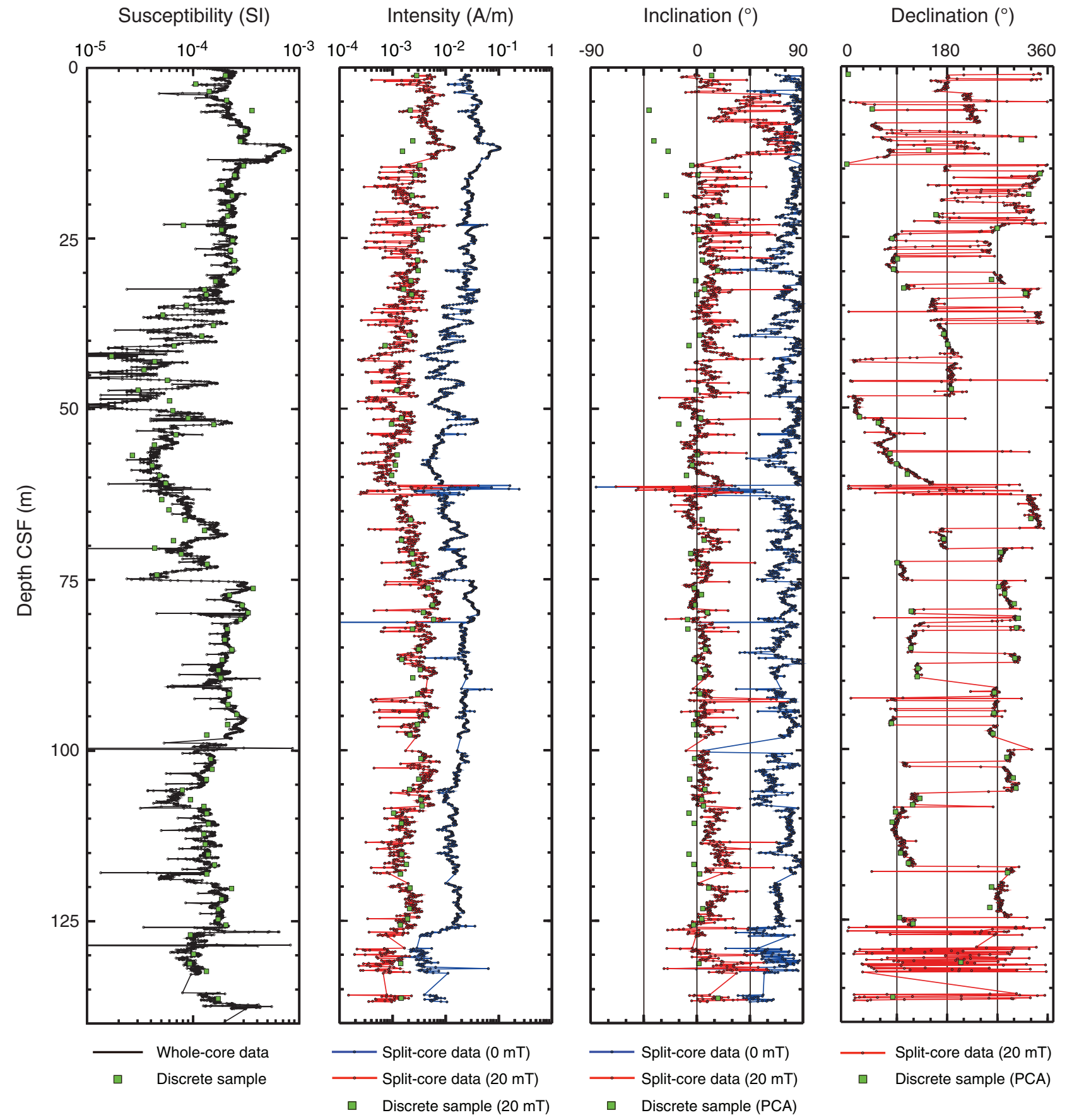


Figure F13. Summary of magnetic susceptibility and paleomagnetic results, Hole U1332B. Declinations are shown in sample coordinates (not reoriented to geographical coordinates).

Hole U1332B

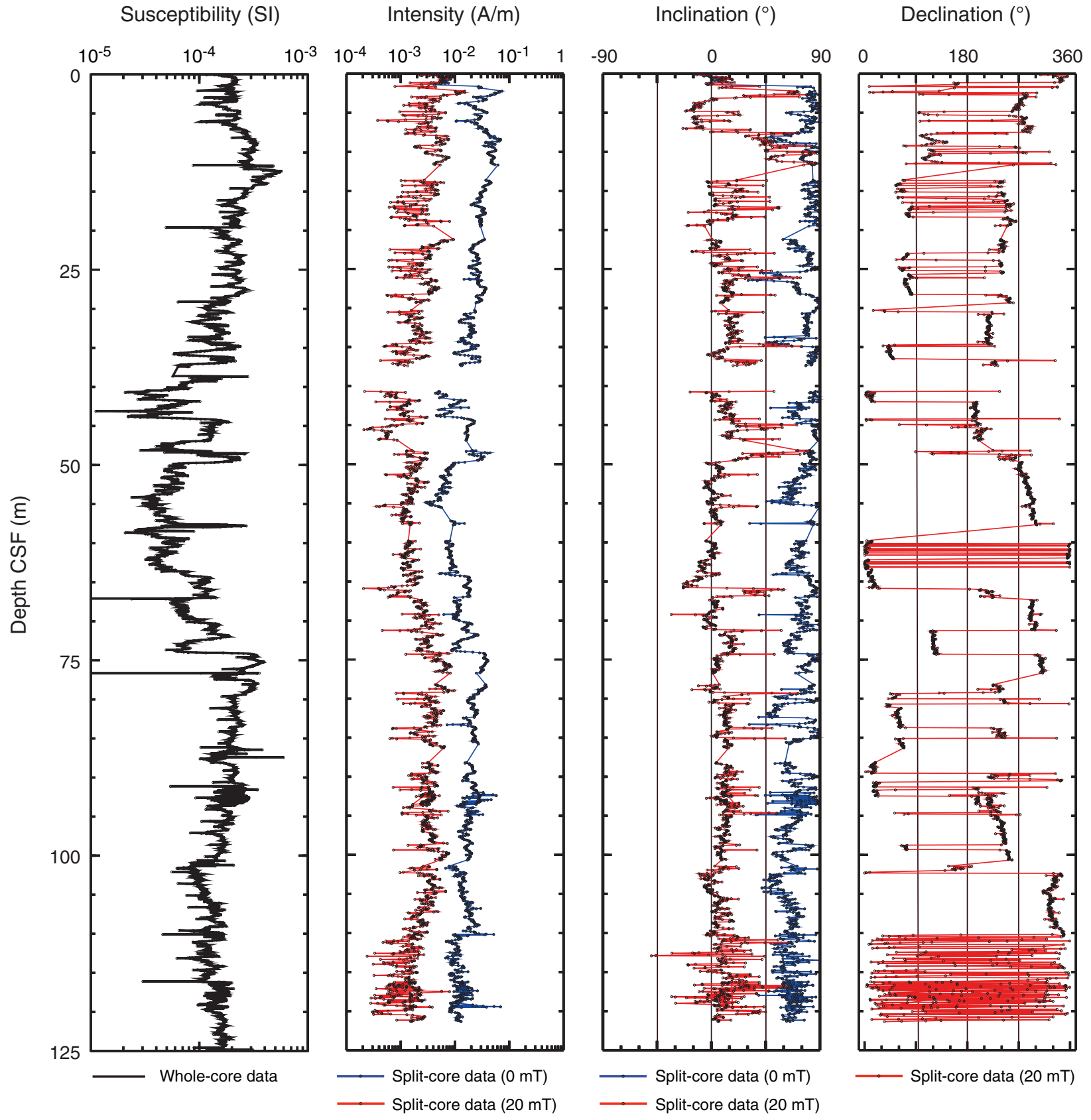


Figure F14. Summary of magnetic susceptibility and paleomagnetic results, Hole U1332C. Declinations are shown in sample coordinates (not reoriented to geographical coordinates).

Hole U1332C

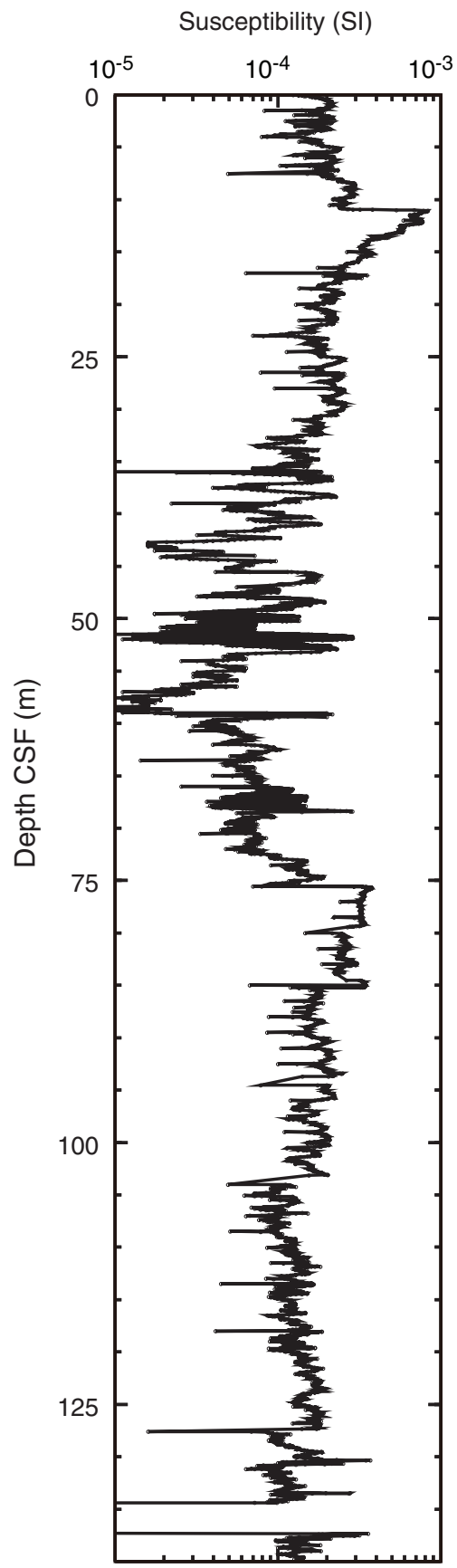

Whole-core data
Intensity $(\mathrm{A} / \mathrm{m})$

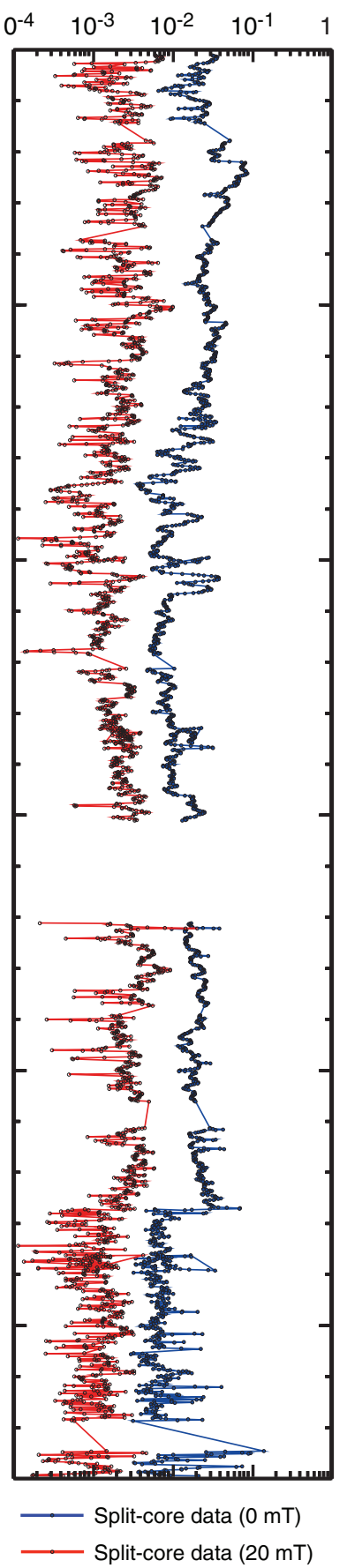

Inclination $\left({ }^{\circ}\right)$

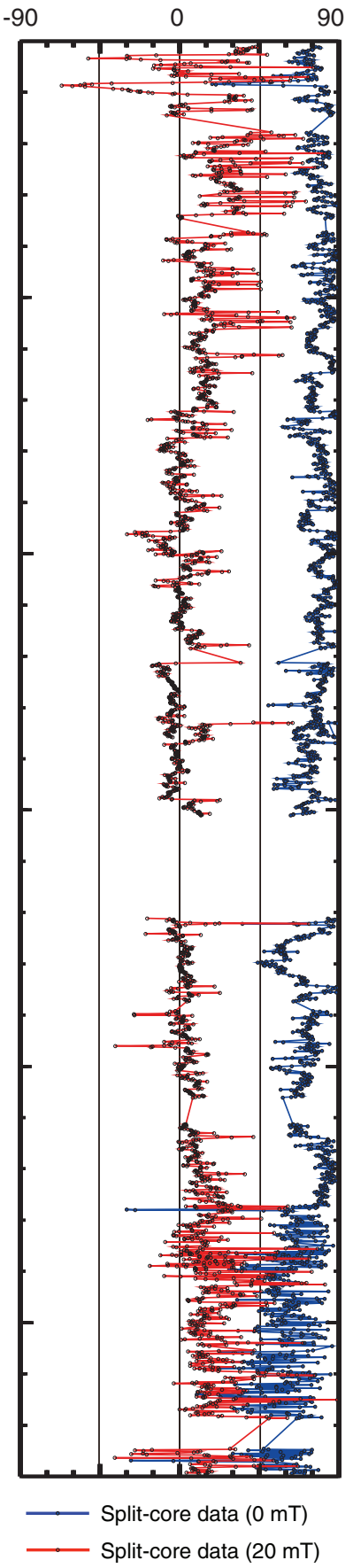

Declination $\left({ }^{\circ}\right)$

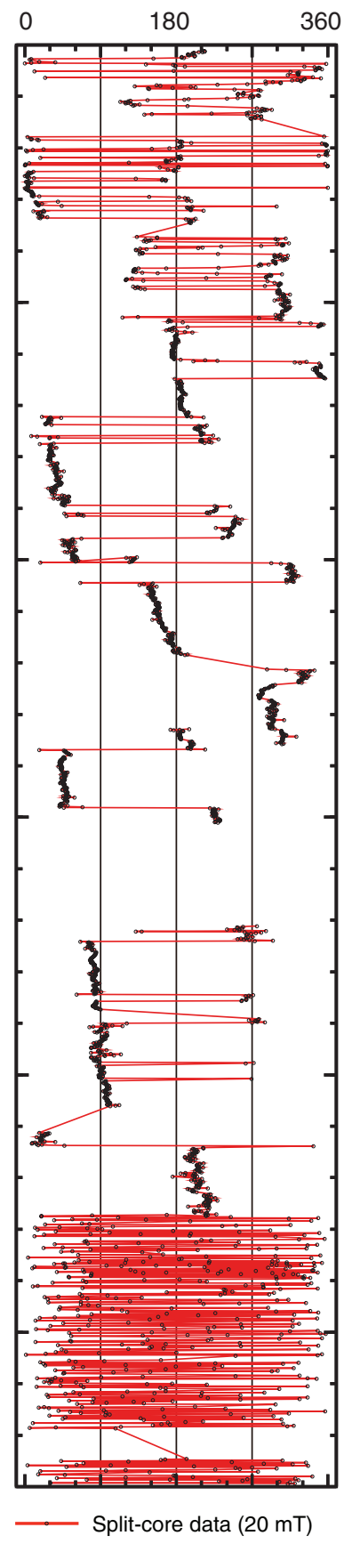


Figure F15. Alternating-field demagnetization (demag) results for four discrete samples. Larger plot shows vector endpoints of paleomagnetic directions on vector demagnetization diagrams or modified Zijderveld plots (solid circles $=$ horizontal projections, open circles = vertical projections, gray circles $=$ data not used in computing ChRM, black dashed line $=$ ChRM direction), smaller plot shows intensity variation with progressive demagnetization. Data illustrate removal of a steep drilling overprint by $\sim 10-15 \mathrm{mT}$, with the remaining magnetization providing a well-resolved characteristic remanent magnetization. A. Sample 320-U1332A-4H-2, 85 cm (25.25 m CSF). B. Sample 320-U1332A-5H-5, 85 cm (39.25 m CSF). C. Sample 320-U1332A-9H-7, 45 cm (79.85 m CSF). D. Sample 320-U1332A-12H-6, $85 \mathrm{~cm}$ (107.25 m CSF). NRM = natural remanent magnetization. Inc $=$ inclination, $\mathrm{Dec}=$ declination, $\mathrm{MAD}=$ maximum angular deviation .

A

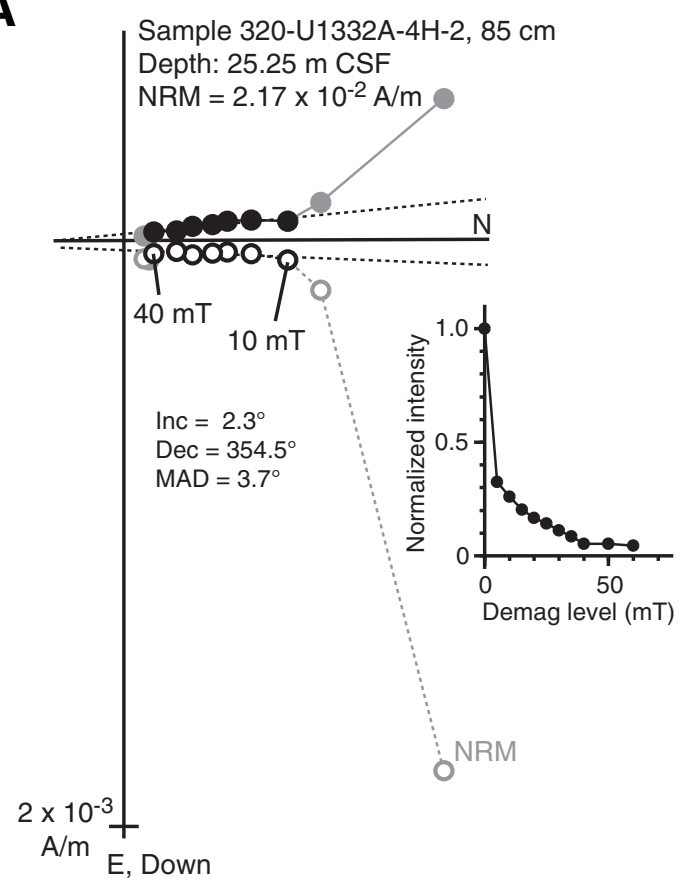

C

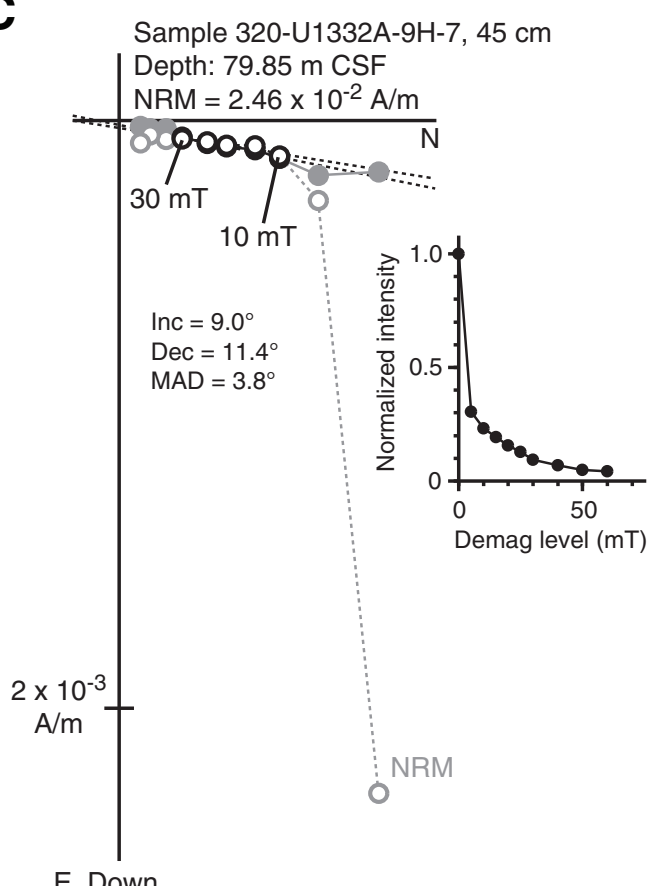

B

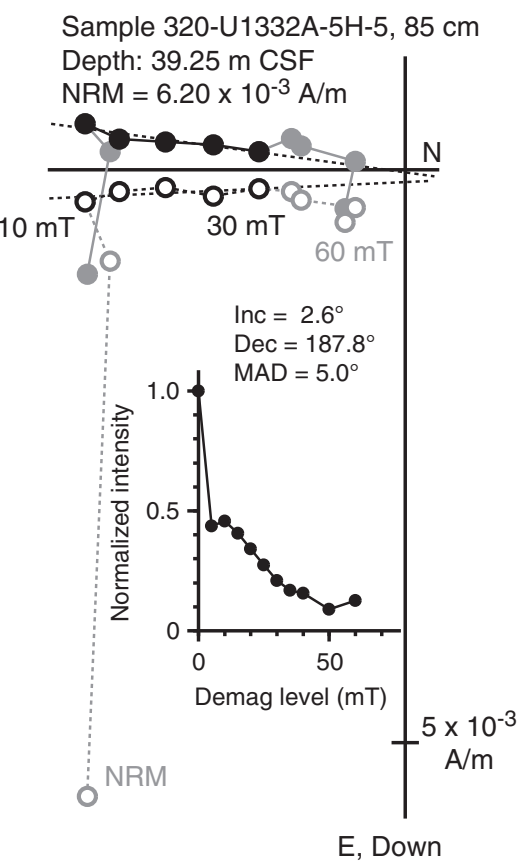

D

Sample 320-U1332A-12H-6, $85 \mathrm{~cm}$ Depth: $107.25 \mathrm{~m} \mathrm{CSF}$ $\mathrm{NRM}=6.74 \times 10^{-3} \mathrm{~A} / \mathrm{m}$

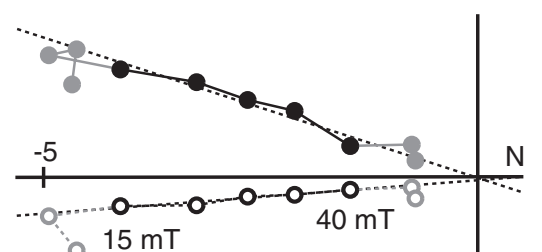

$15 \mathrm{mT}$

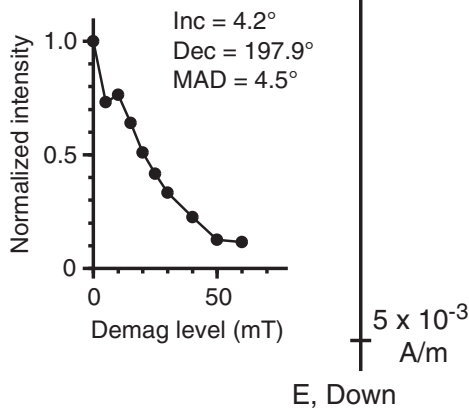


Figure F16. Variations of virtual geomagnetic pole (VGP) latitude and geographic declination, Hole U1332A. Variations computed using paleomagnetic data after $20 \mathrm{mT}$ demagnetization. Geographic declinations calculated by subtracting mean paleomagnetic declination of each core (indicated in Table T23) from raw declination values. North latitudes $=$ normal polarity, south latitudes $=$ reversed polarity. $\mathrm{O} / \mathrm{M}=$ Oligocene/Miocene boundary, $\mathrm{E} / \mathrm{O}=$ Eocene/Oligocene boundary.

Hole U1332A

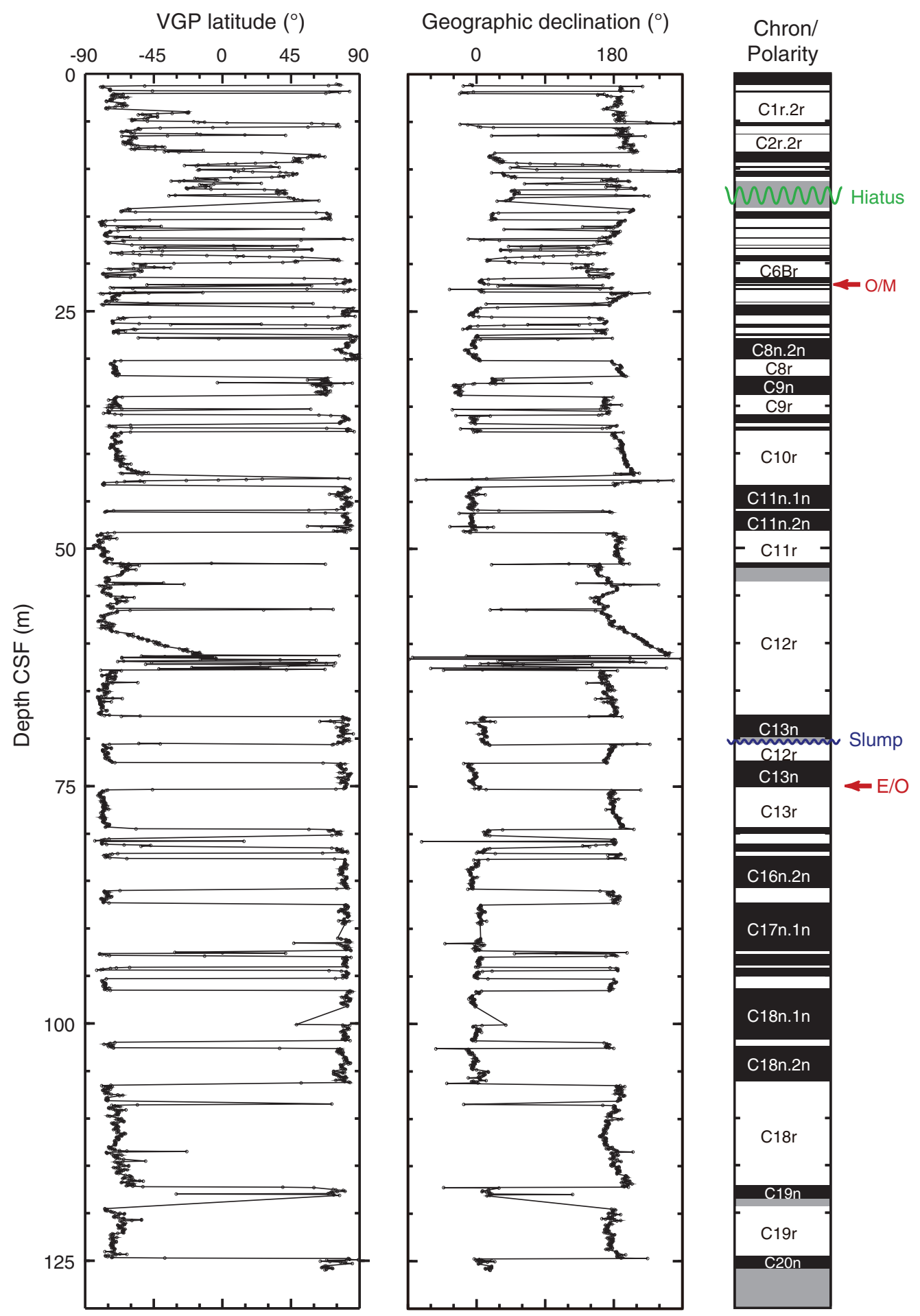


Figure F17. Variations of virtual geomagnetic pole (VGP) latitude and geographic declination, Hole U1332B. Variations computed using paleomagnetic data after $20 \mathrm{mT}$ demagnetization. Geographic declinations calculated by subtracting mean paleomagnetic declination of each core (indicated in Table T23) from raw declination values. North latitudes $=$ normal polarity, south latitudes $=$ reversed polarity. $\mathrm{O} / \mathrm{M}=$ Oligocene/Miocene boundary, $\mathrm{E} / \mathrm{O}=$ Eocene/Oligocene boundary.

Hole U1332B

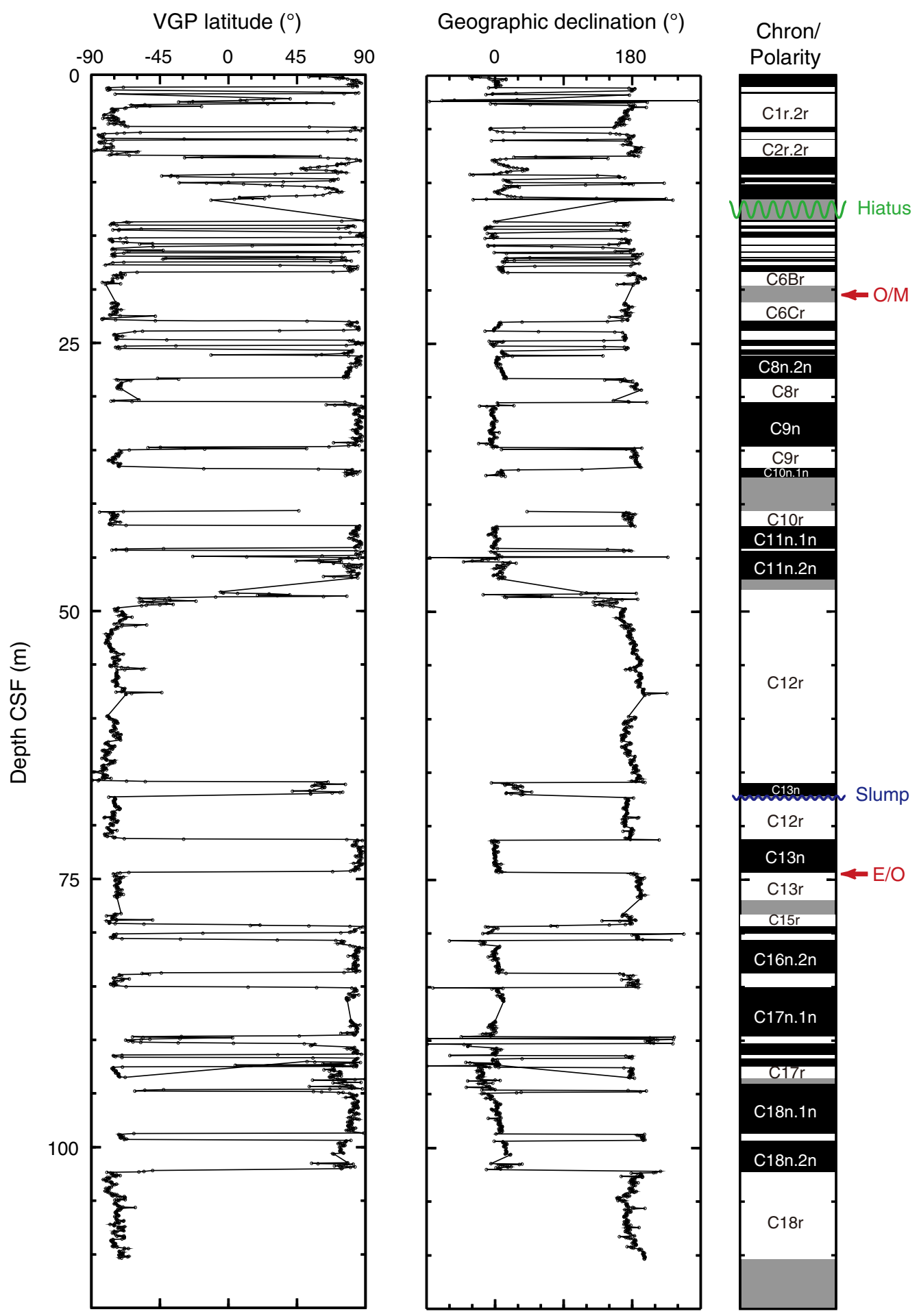


Figure F18. Variations of virtual geomagnetic pole (VGP) latitude and geographic declination, Hole U1332C. Variations computed using paleomagnetic data after $20 \mathrm{mT}$ demagnetization. Geographic declinations calculated by subtracting mean paleomagnetic declination of each core (indicated in Table T23) from raw declination values. North latitudes $=$ normal polarity, south latitudes $=$ reversed polarity. $\mathrm{O} / \mathrm{M}=$ Oligocene/Miocene boundary, $\mathrm{E} / \mathrm{O}=$ Eocene/Oligocene boundary.

Hole U1332C
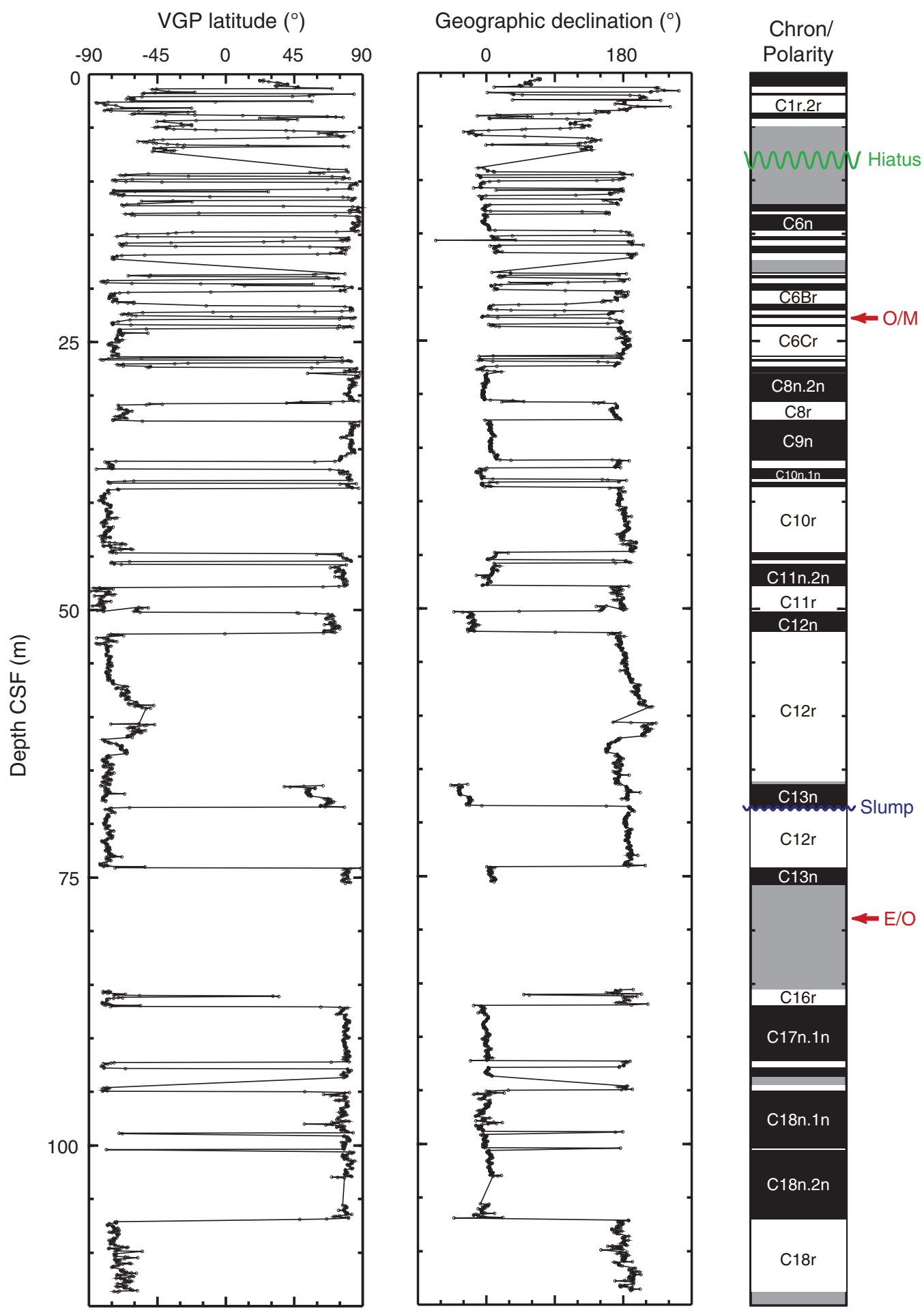
Figure F19. Comparison of magnetostratigraphy determined from each hole. Dotted lines = some representative iso-boundaries of geomagnetic chrons, solid lines = Oligocene/Miocene $(\mathrm{O} / \mathrm{M})$ and Eocene/Oligocene (E/O) boundaries.

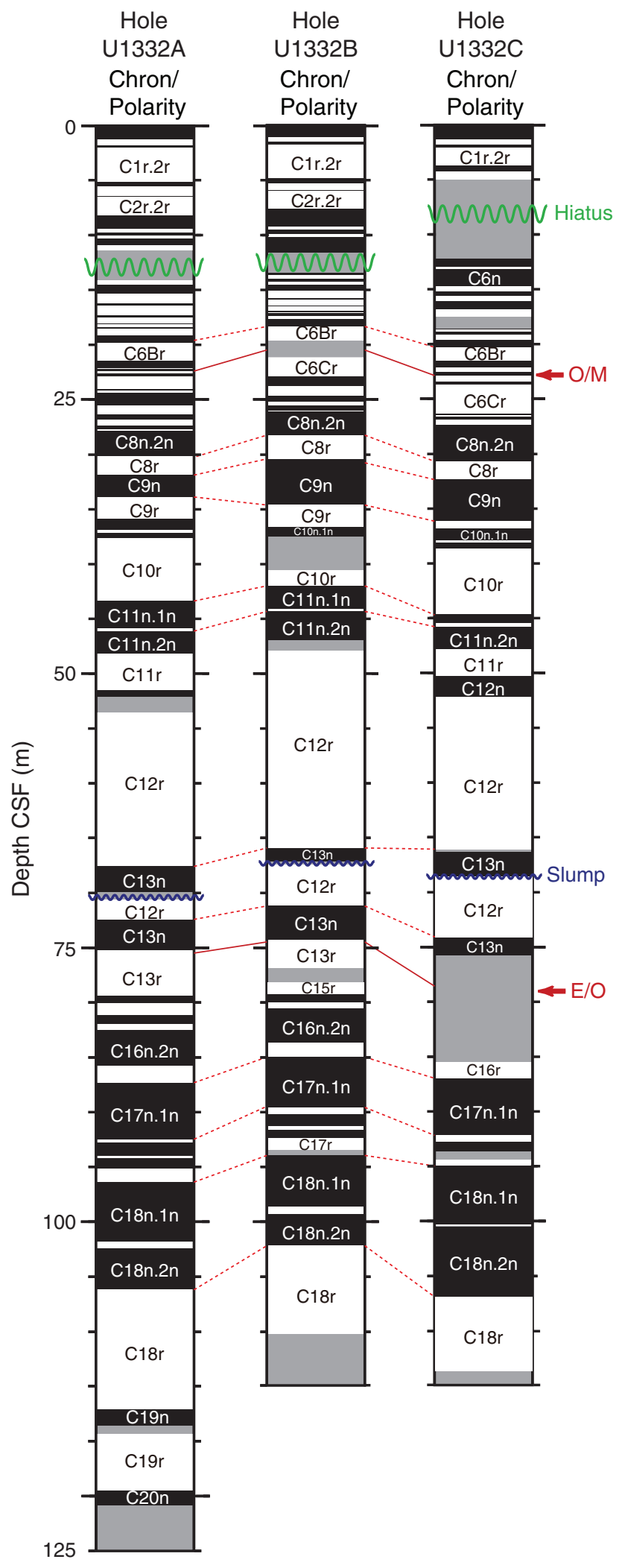


Figure F20. Variations of geographic declinations and remanent magnetization (after $20 \mathrm{mT}$ demagnetization) for the slump interval in Cores 320-U1332A-8H and 9H. Correlatable variations in intensity are marked by letters $\mathrm{a}-\mathrm{i}$.

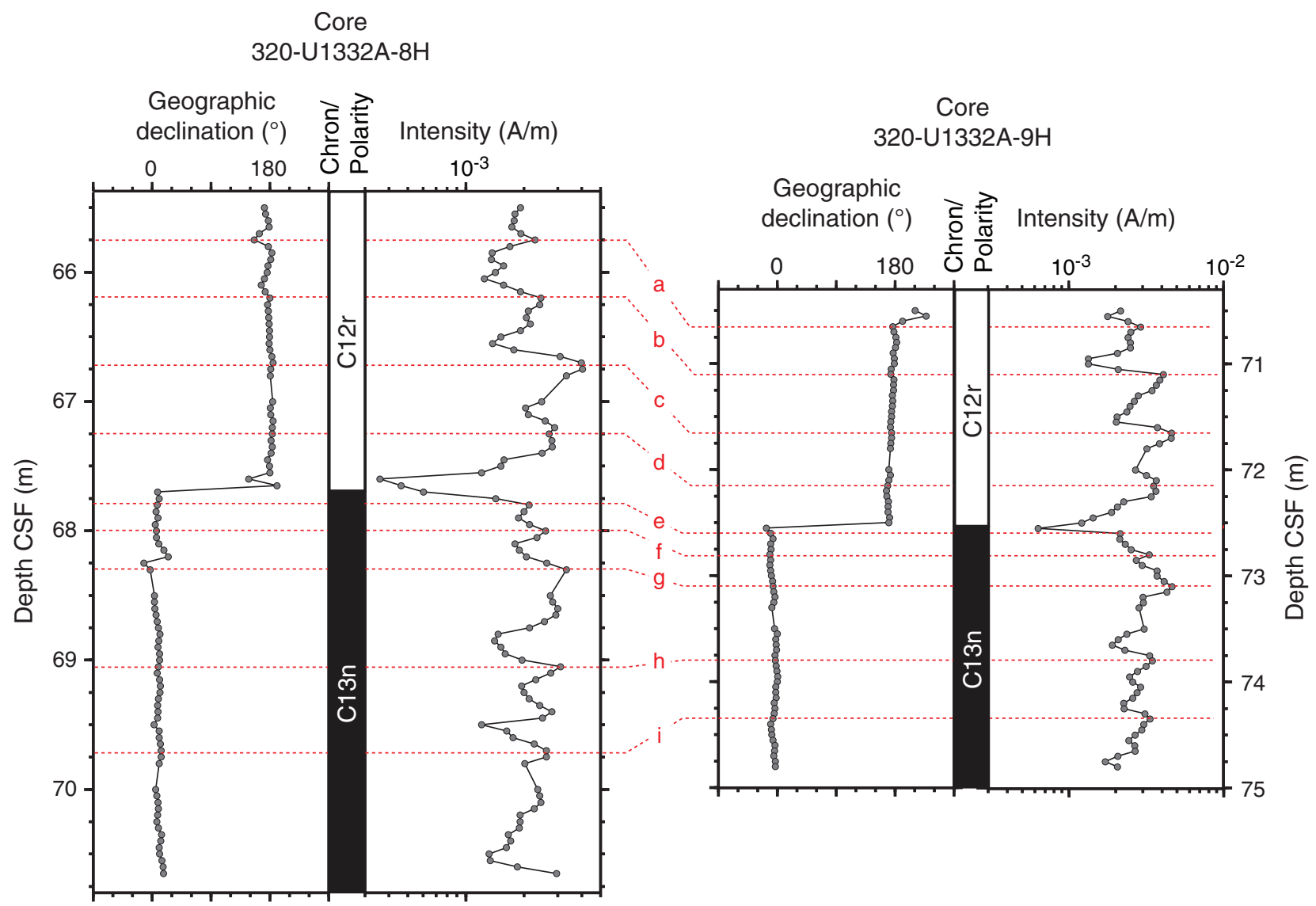


Figure F21. Variations of geographic declinations and remanent magnetization (after $20 \mathrm{mT}$ demagnetization) for the slump interval in Cores 320-U1332B-8H and 9H. Features marked by letters a-d, g, and h can be correlated to those in Figure F20.

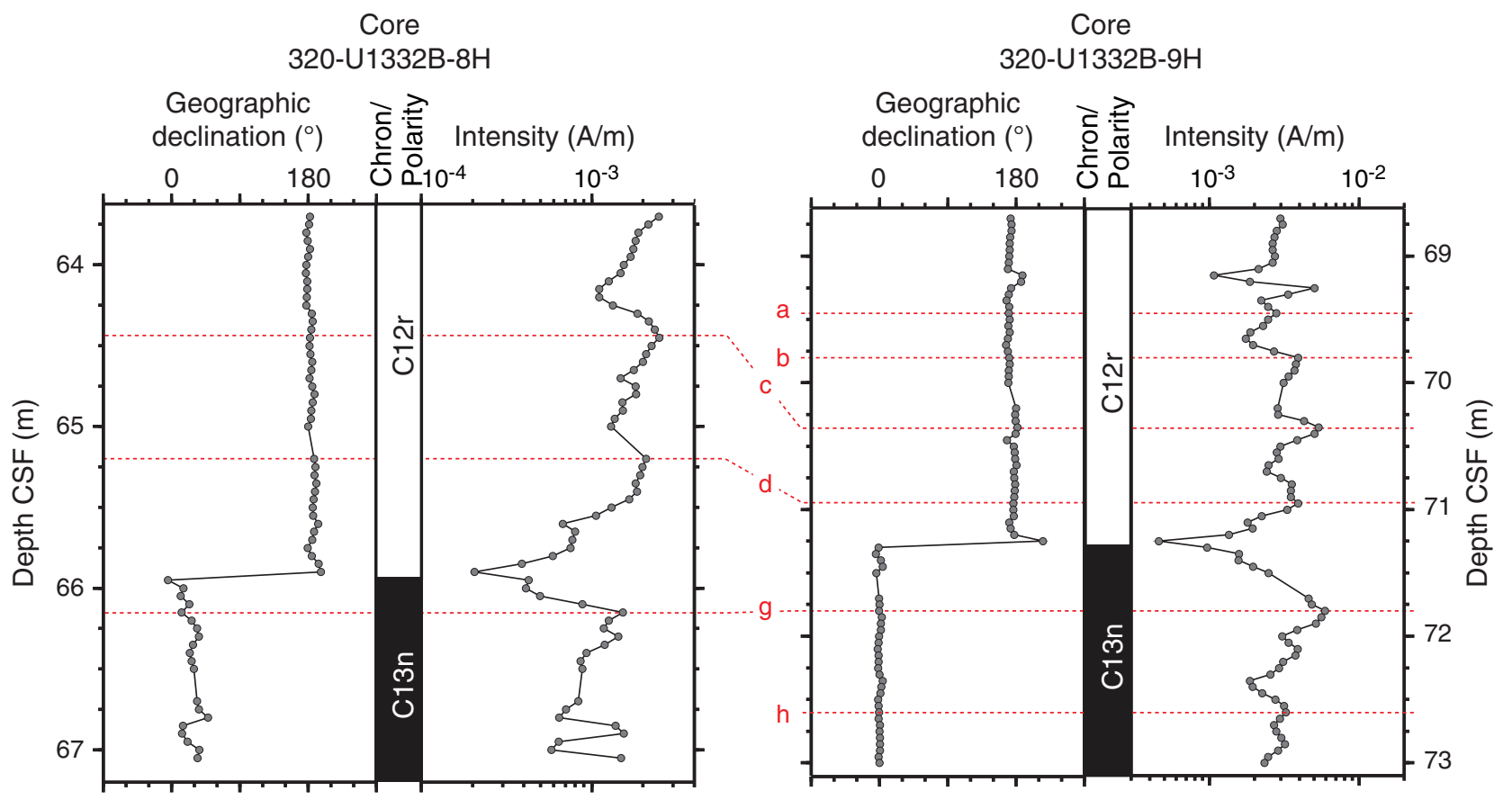


Figure F22. Variations of geographic declinations and remanent magnetization (after $20 \mathrm{mT}$ demagnetization) for the slump interval in Core 320-U1332C-9H. Features marked by letters a-d, $\mathrm{g}$, and $\mathrm{h}$ can be correlated to those in Figure F20.

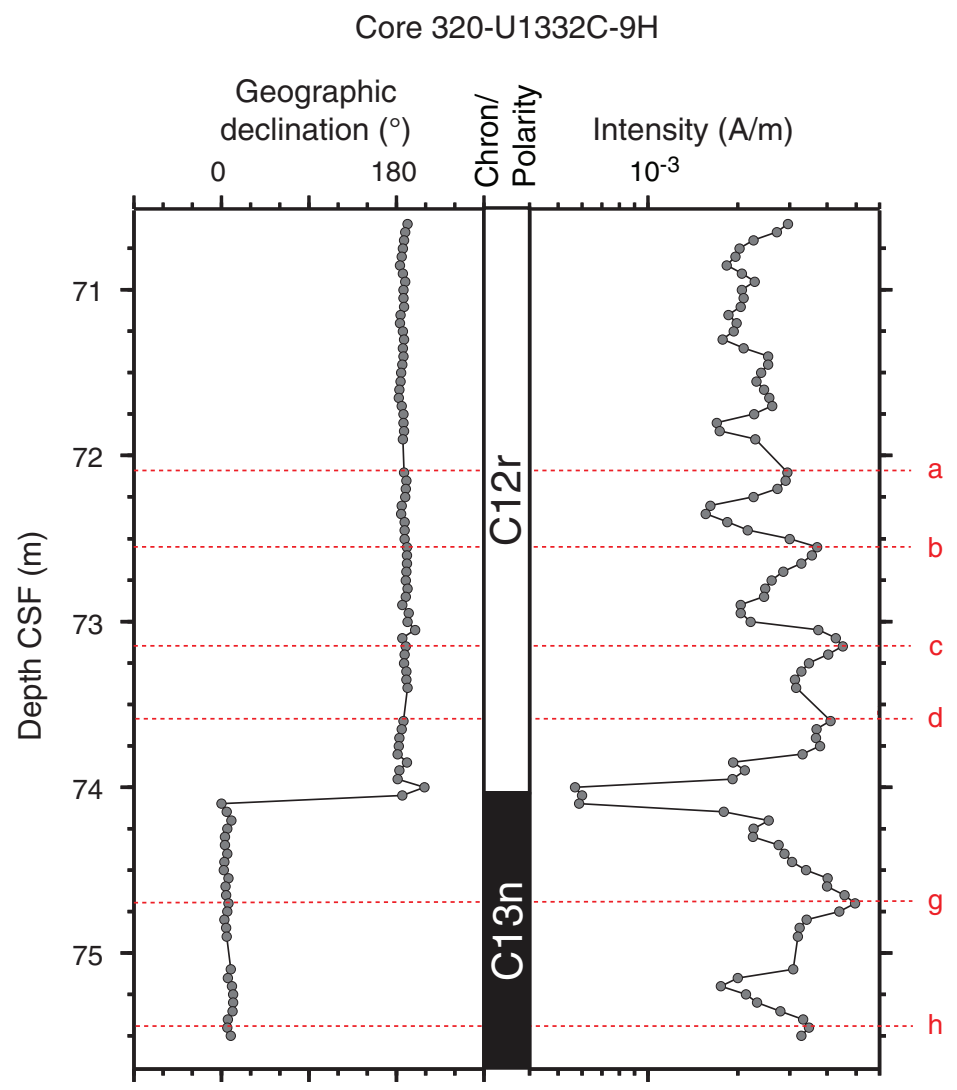


Figure F23. Interstitial water chemistry, Hole U1332A. Values below the detection limit (see Table T26) are plotted as zero. (See "Lithostratigraphy" for information on unit boundaries.) (Continued on next page.)
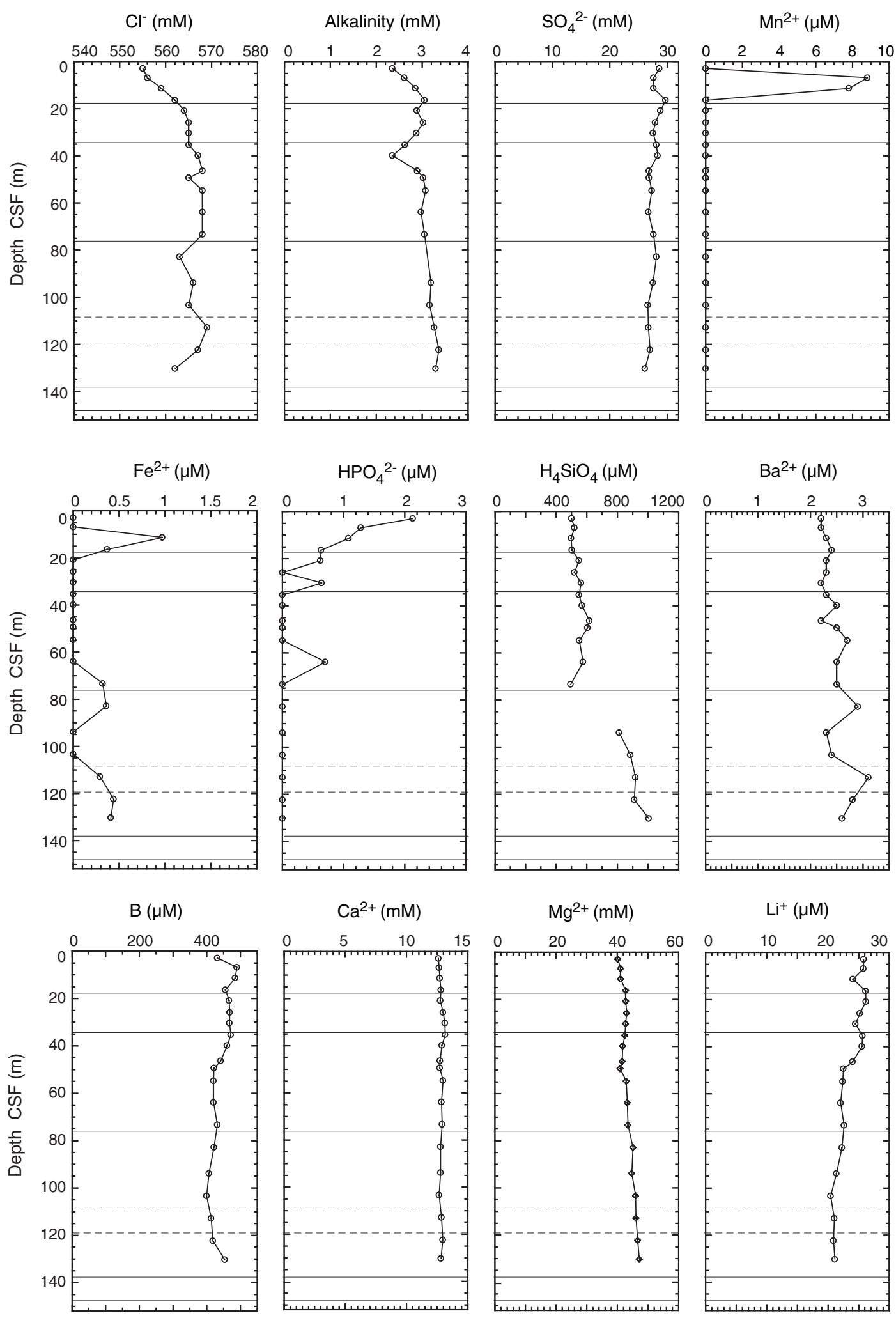
Figure F23 (continued). Interstitial water chemistry, Hole U1332A.

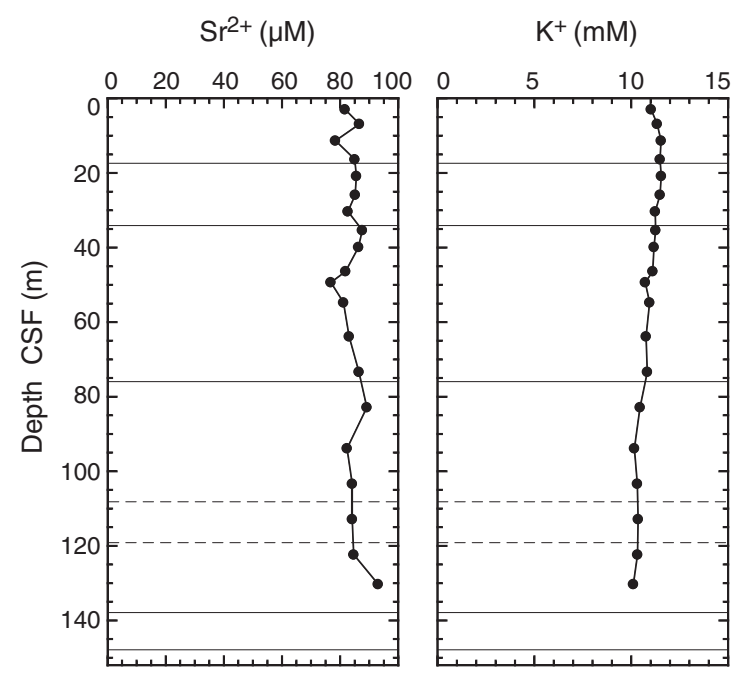


Figure F24. Interstitial water chemistry data from Rhizon samples, Hole U1332C. Values below the detection limit (see Table T27) are plotted as zero.

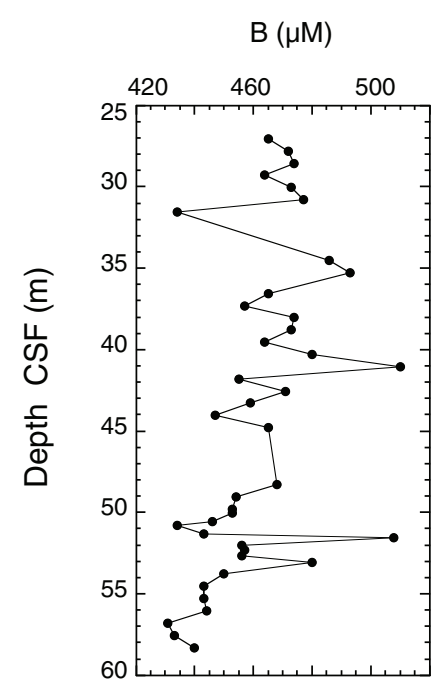

$\mathrm{Li}^{+}(\mu \mathrm{M})$
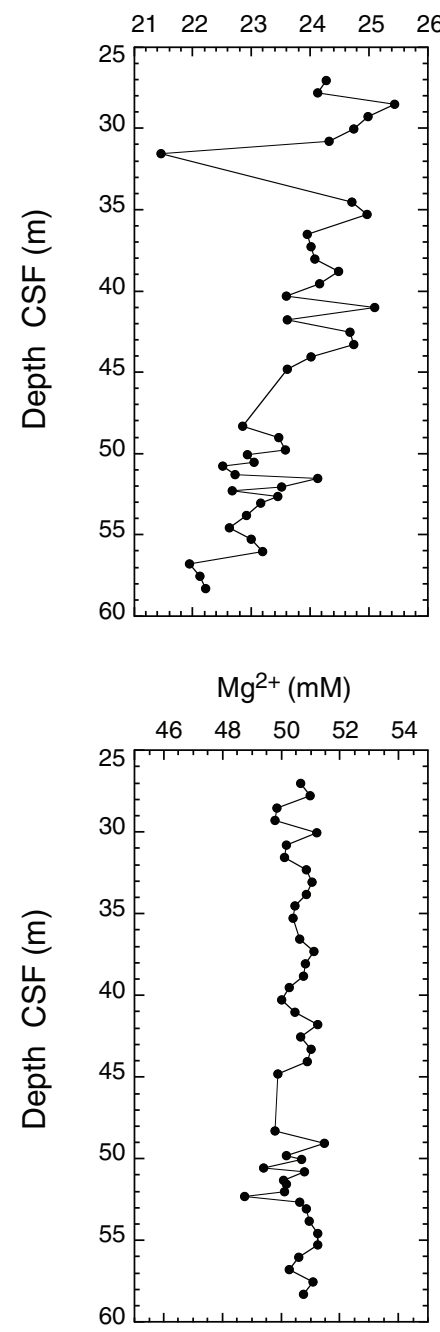
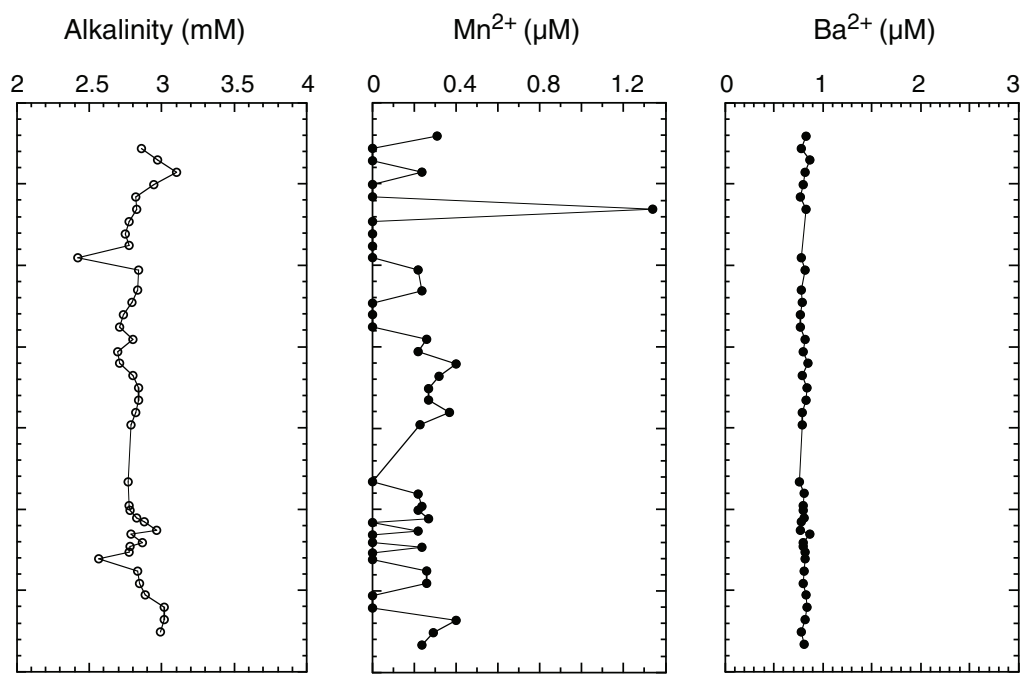

$\mathrm{Fe}^{2+}(\mu \mathrm{M})$
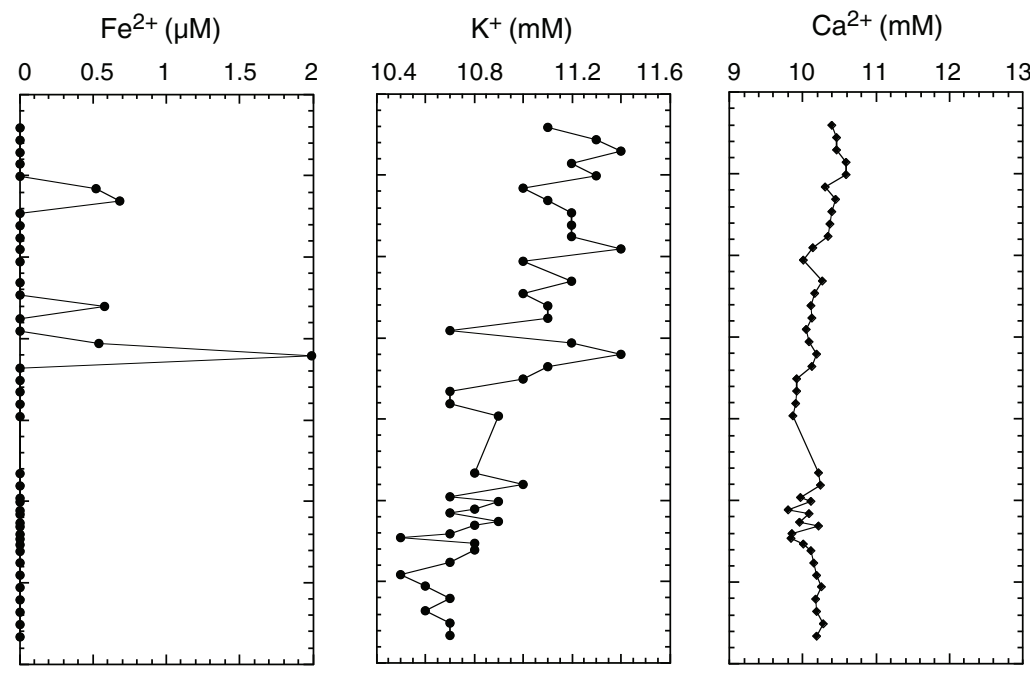
Figure F25. Interstitial water chemistry, Site U1332. Values below the detection limit (see Tables T26, T27) are plotted as zero. Note offsets in concentration scales for $\mathrm{Ca}^{2+}$ and $\mathrm{Mg}^{2+}$ for whole-round and Rhizon samples. Rhizon samples are from Hole U1332C; whole-round (WR) samples are from Hole U1332A.
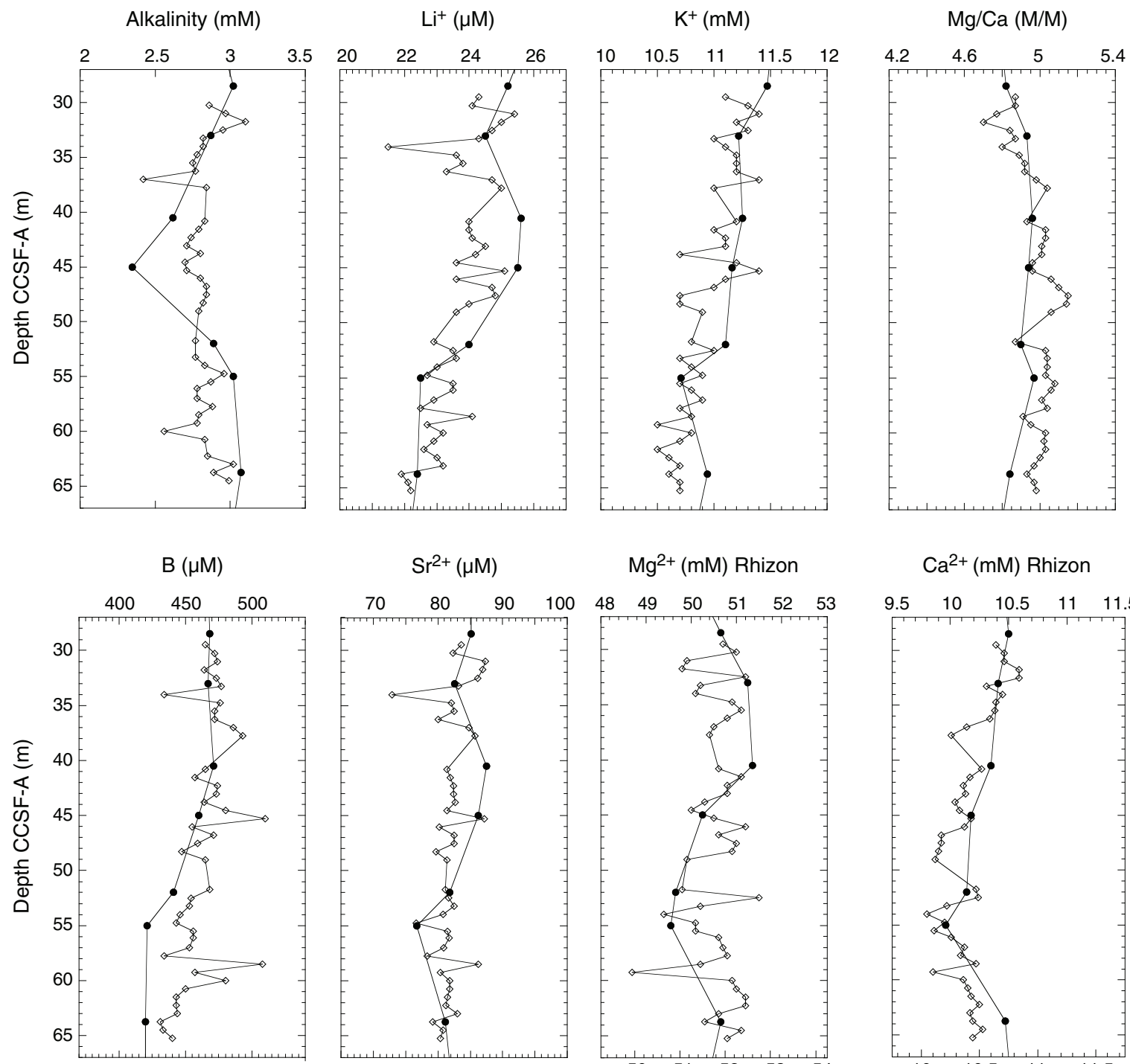

$$
\mathrm{Mg}^{2+}(\mathrm{mM}) \text { Rhizon }
$$

$$
\mathrm{Ca}^{2+}(\mathrm{mM}) \text { Rhizon }
$$
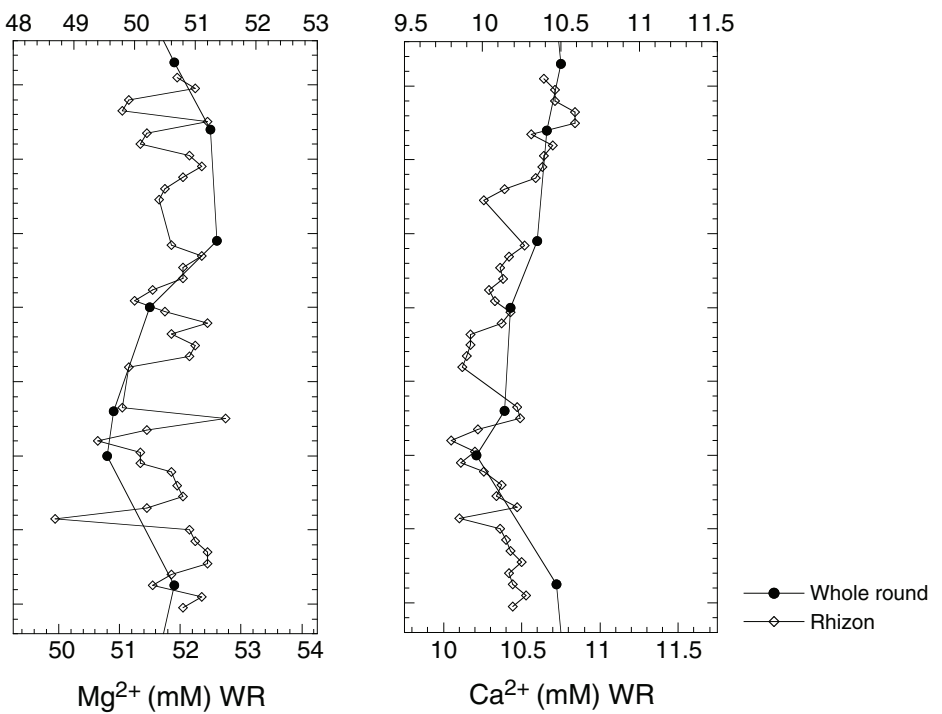
Figure F26. Calcium carbonate $\left(\mathrm{CaCO}_{3}\right)$, total carbon (TC), inorganic carbon (IC), and total organic carbon (TOC) determined by difference and acidification methods in sediments from Hole U1332A. (See "Lithostratigraphy" for information on unit boundaries.)
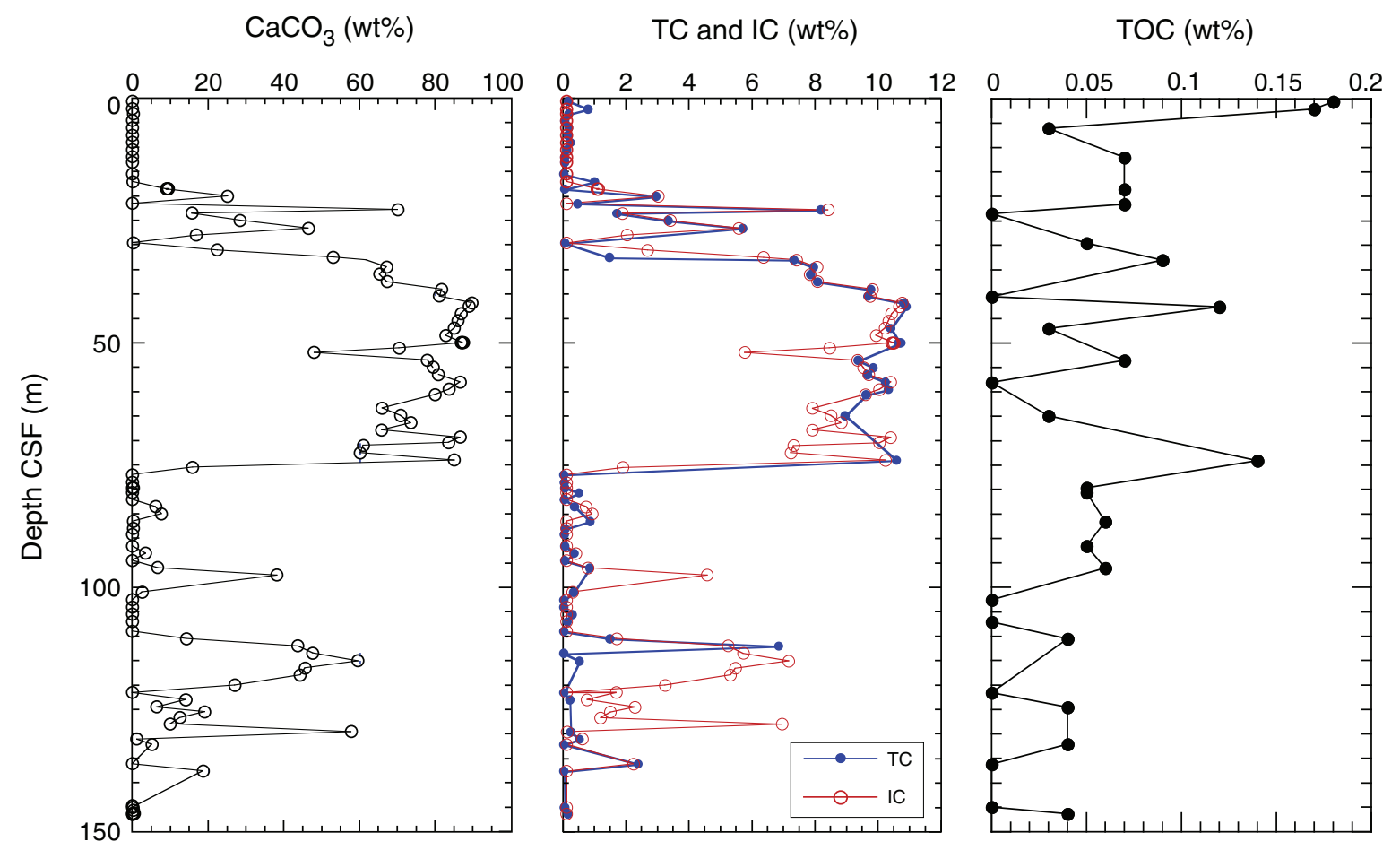
Figure F27. Whole-Round Multisensor Logger (WRMSL) and natural gamma radiation (NGR) data, Holes U1332A-U1332C. Hole U1332B and U1332C data are plotted using offsets $\left(0.5\right.$ and $1 \mathrm{~g} / \mathrm{cm}^{3}$ for gamma ray attenuation [GRA] bulk density; 10 and $20 \times 10^{-5}$ SI for magnetic susceptibility; 100 and $200 \mathrm{~m} / \mathrm{s}$ for $P$-wave velocity; 10 and 20 cps for NGR).

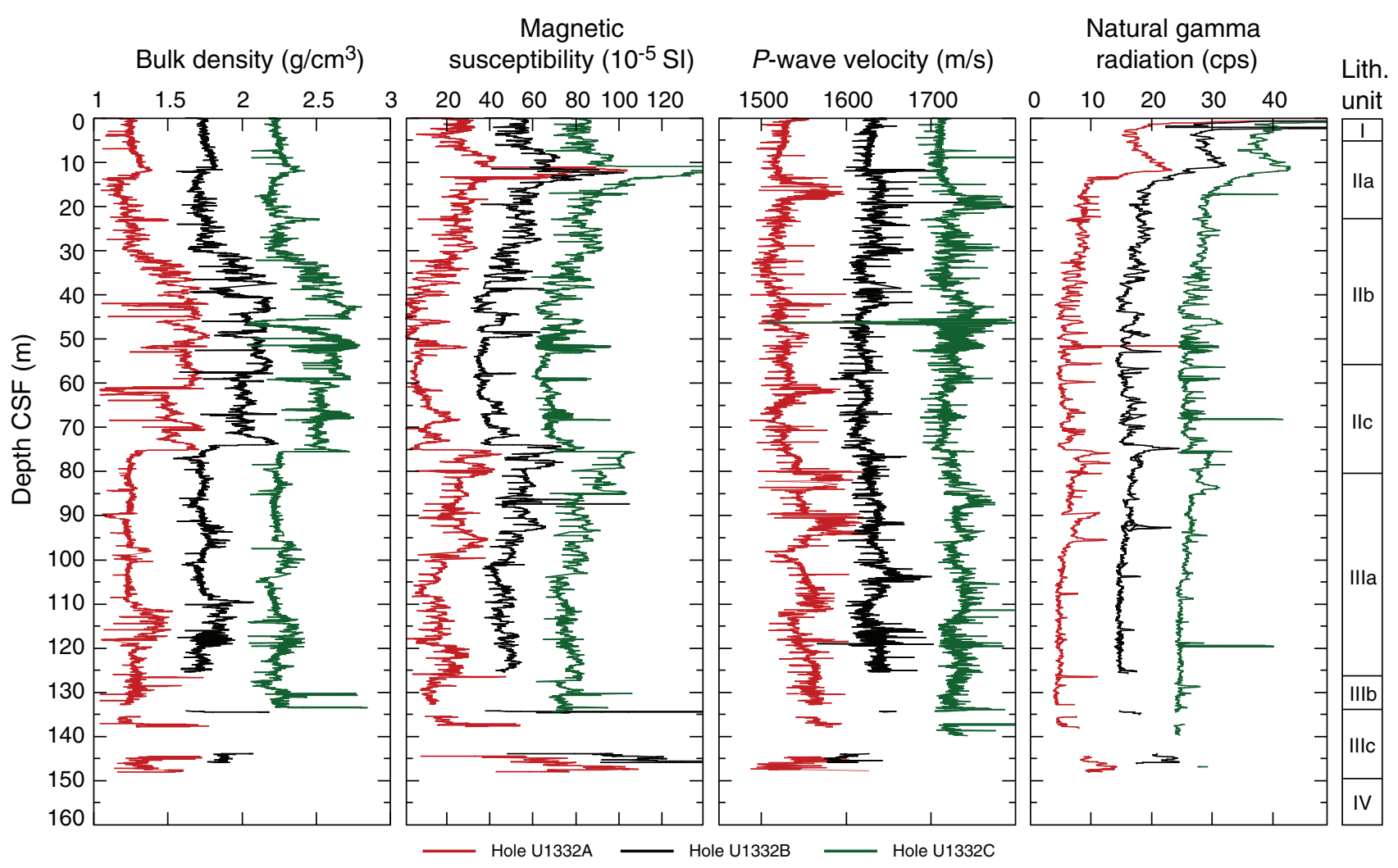


Figure F28. Moisture and density measurements, Hole U1332A. GRA = gamma ray attenuation.
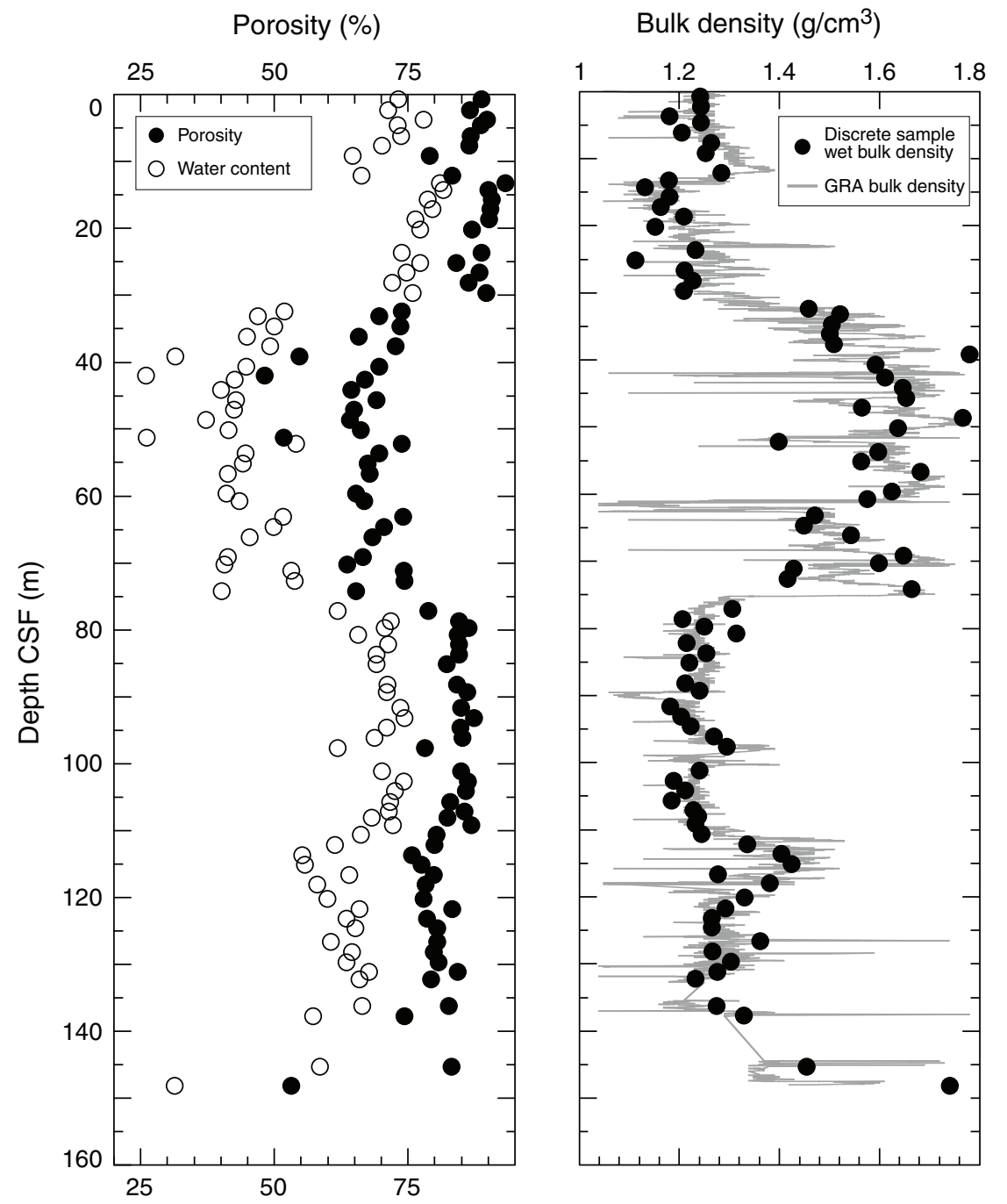

Grain density $\left(\mathrm{g} / \mathrm{cm}^{3}\right)$

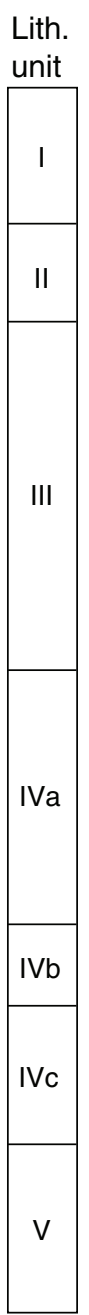

Water content (\%) 
Figure F29. Moisture and density (MAD) analysis of discrete samples, Hole U1332A. Gamma ray attenuation (GRA) density interpolated with a $20 \mathrm{~cm}$ wide Gaussian window.
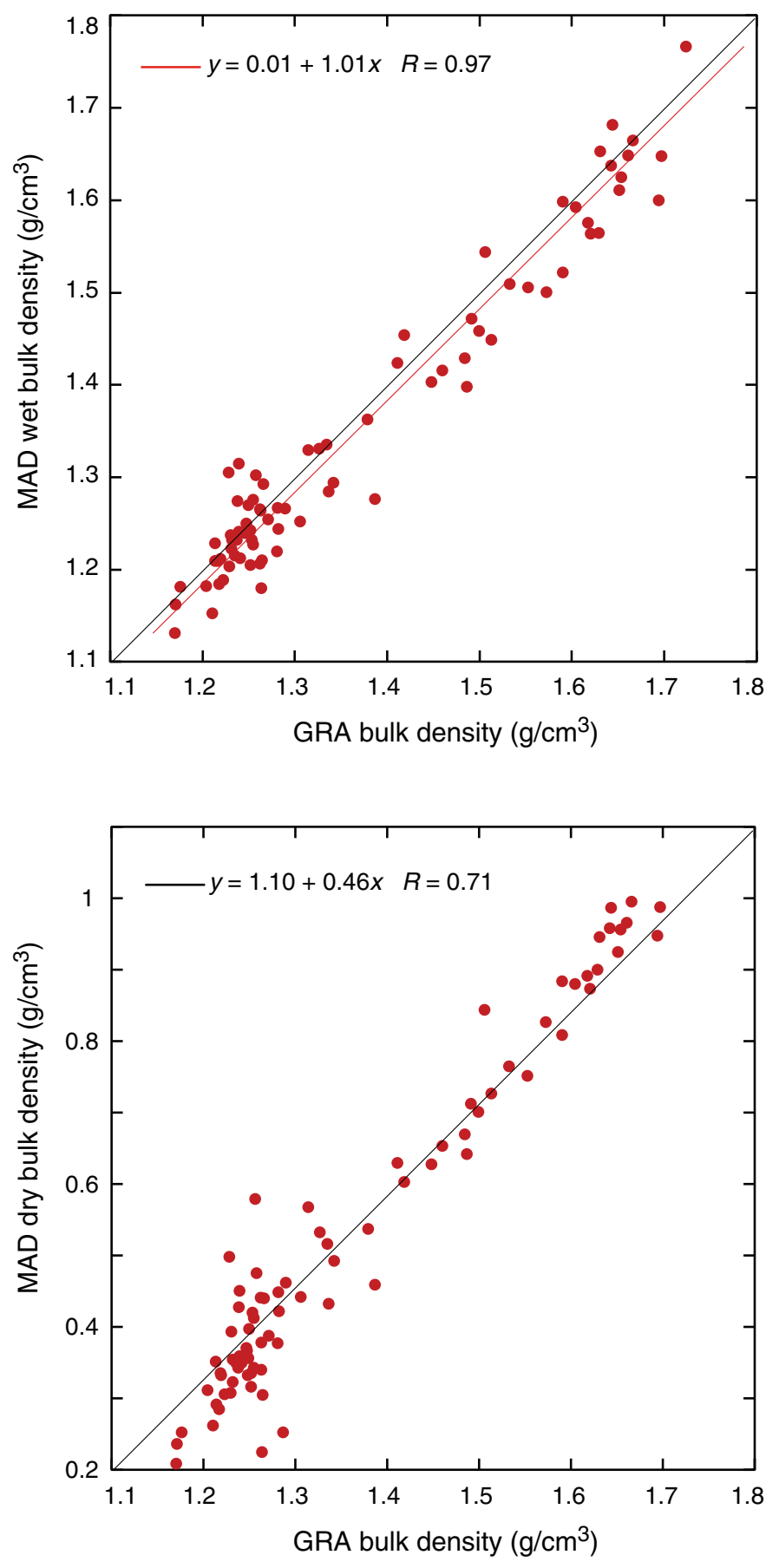
Figure F30. Compressional wave velocity from the $P$-wave logger (PWL) and discrete velocity measurements on split core from Hole U1332A, using the contact probe for $x$-axis measurements and insertion probes for $y$ and $z$-axis measurements. (see "Compressional wave velocity" for note on postcruise velocity correction.)

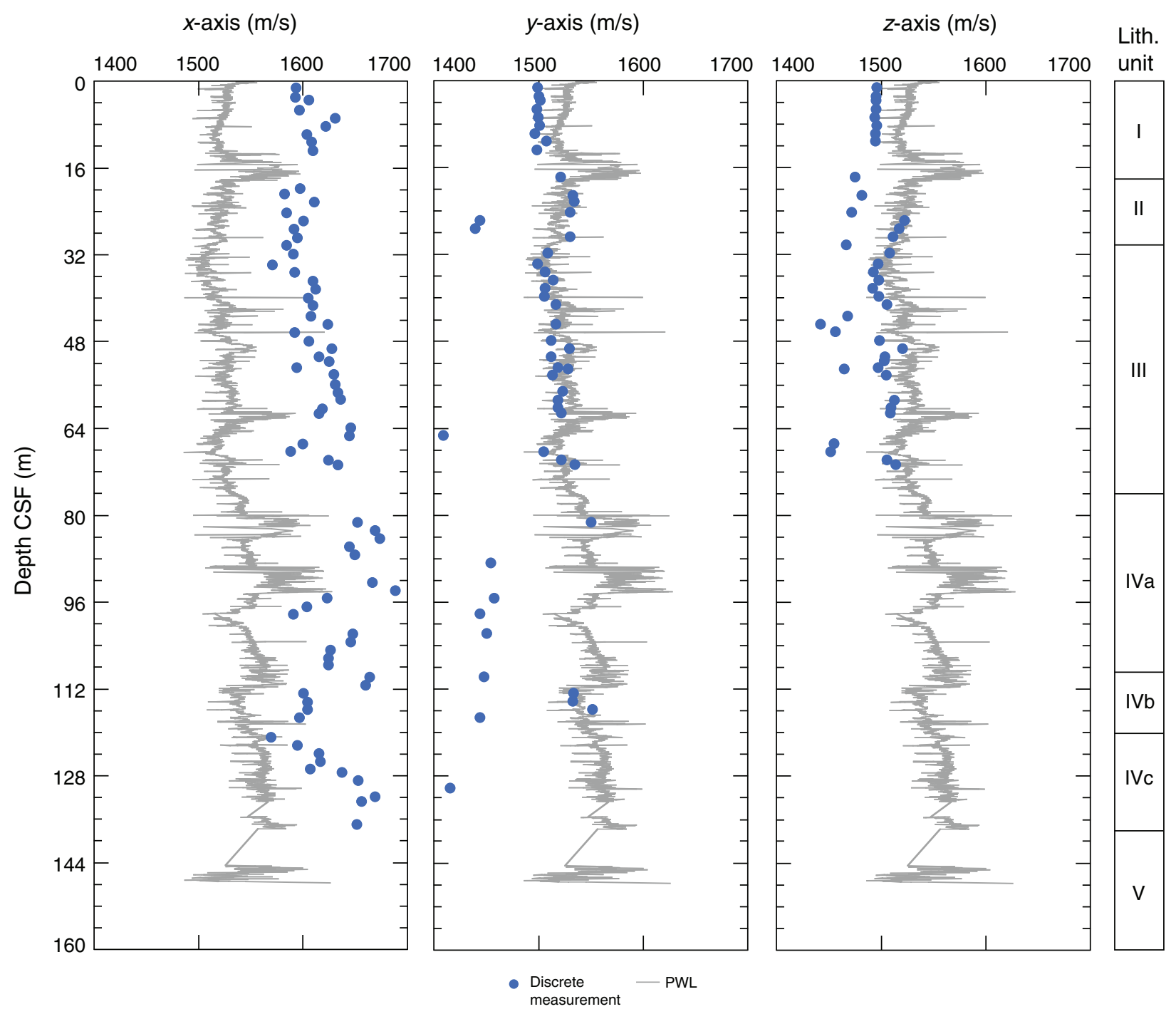


Figure F31. Compressional wave velocity from the $P$-wave logger (PWL) plotted with wet bulk density (MAD measurements).

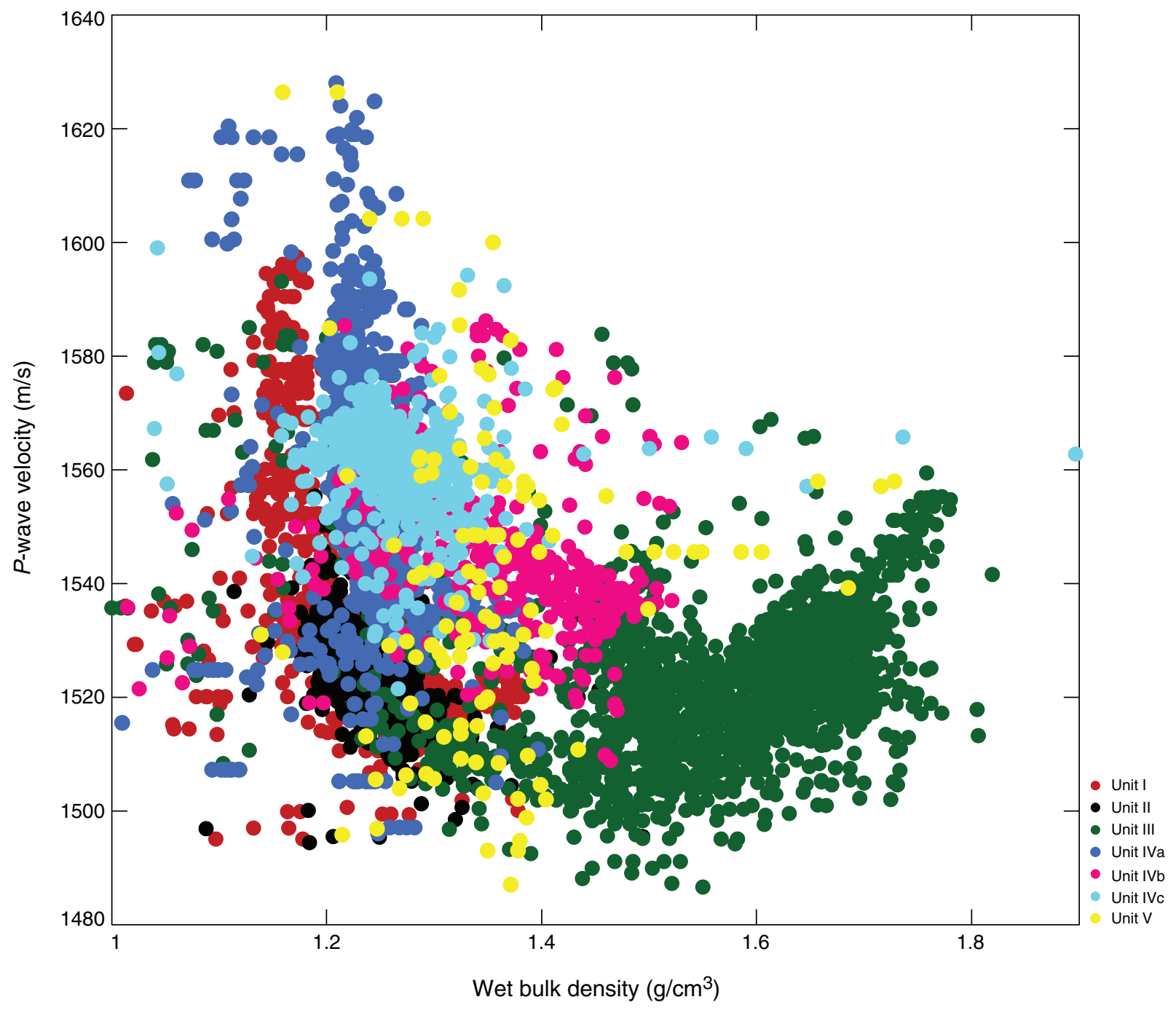


Figure F32. Thermal conductivity measurements, Hole U1332A.

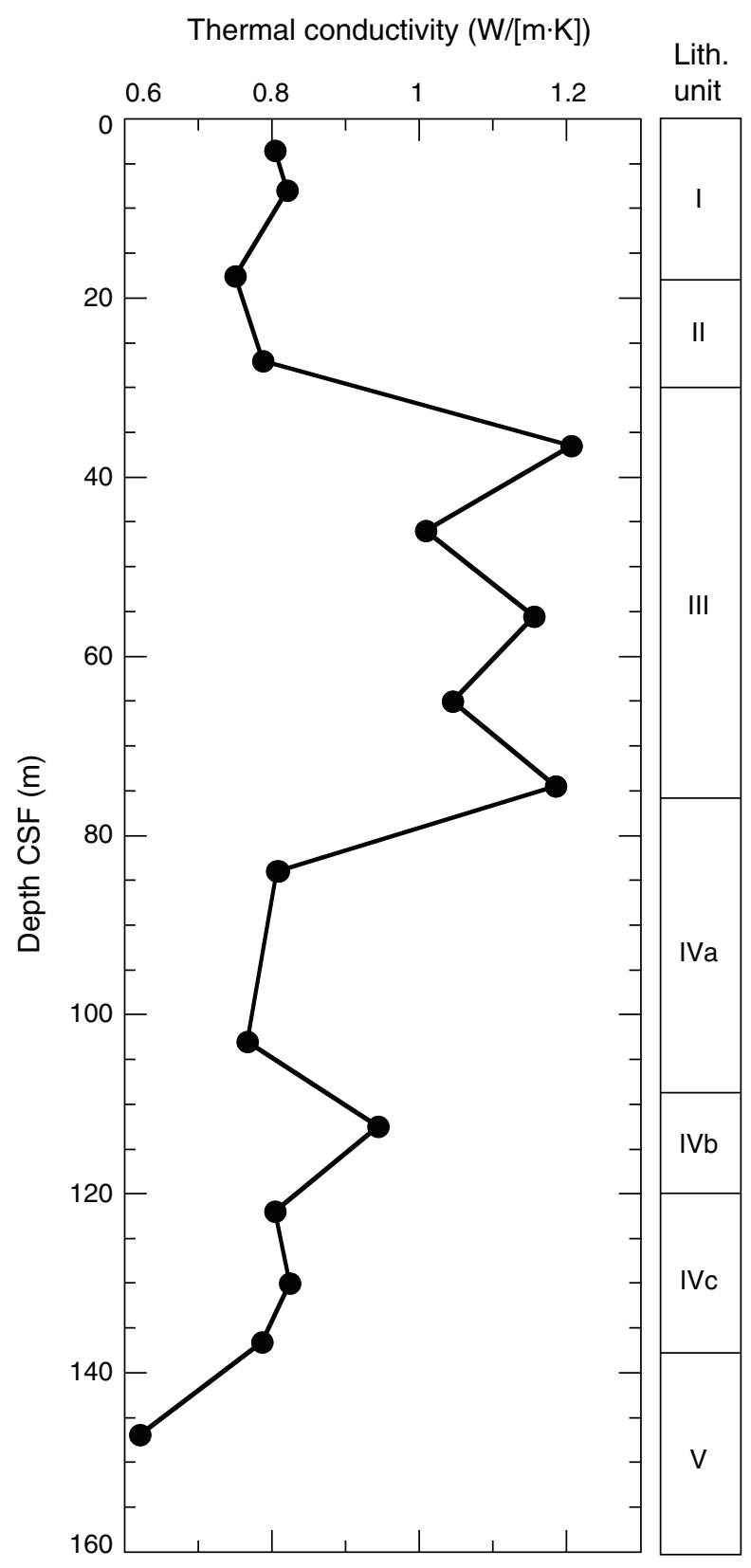


Figure F33. Reflectance spectrophotometer (RSC) data, Holes U1332A-U1332C. RSC for Holes U1332B and U1332C have been offset ( 20 and 40 for $\mathrm{L}^{*} ; 5$ and 10 for $\mathrm{a}^{*} ; 10$ and 20 for $\mathrm{b}^{*}$ ) for core to core comparison. $\mathrm{L}^{*}$, $\mathrm{a}^{*}, \mathrm{~b}^{*}=$ reflectance value of sediment as defined in the LAB color model.

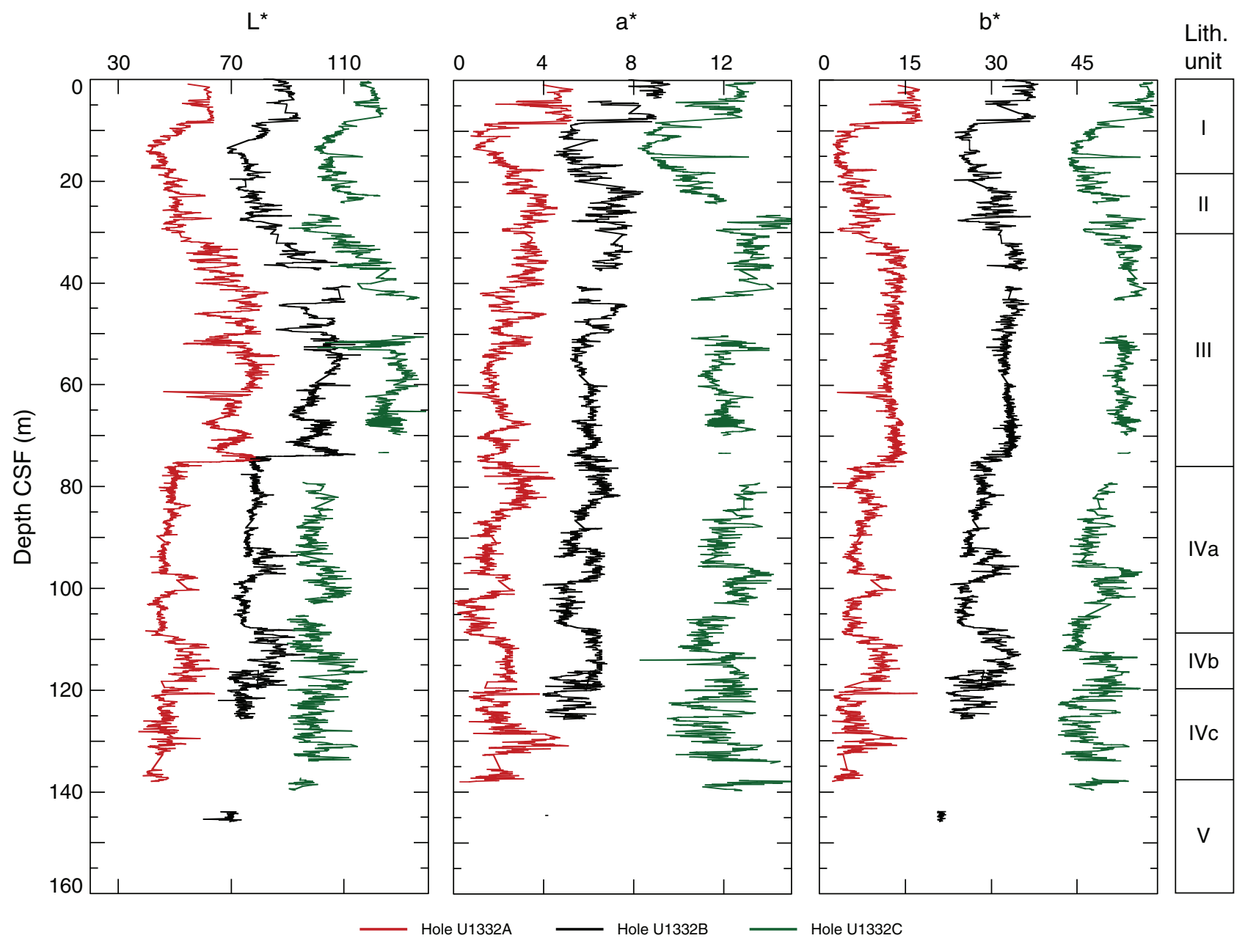


Figure F34. Magnetic susceptibility data, Site U1332. Top panel = spliced section with core breaks (triangles) and hole designations, bottom panel = Holes U1332A (red), U1332B (blue), and U1332C (green), offset from each other by a constant $\left(300 \times 10^{-6} \mathrm{SI}\right)$. A. 0-50 CCSF-A. (Continued on next three pages.)

A

Depth CCSF-A (m)
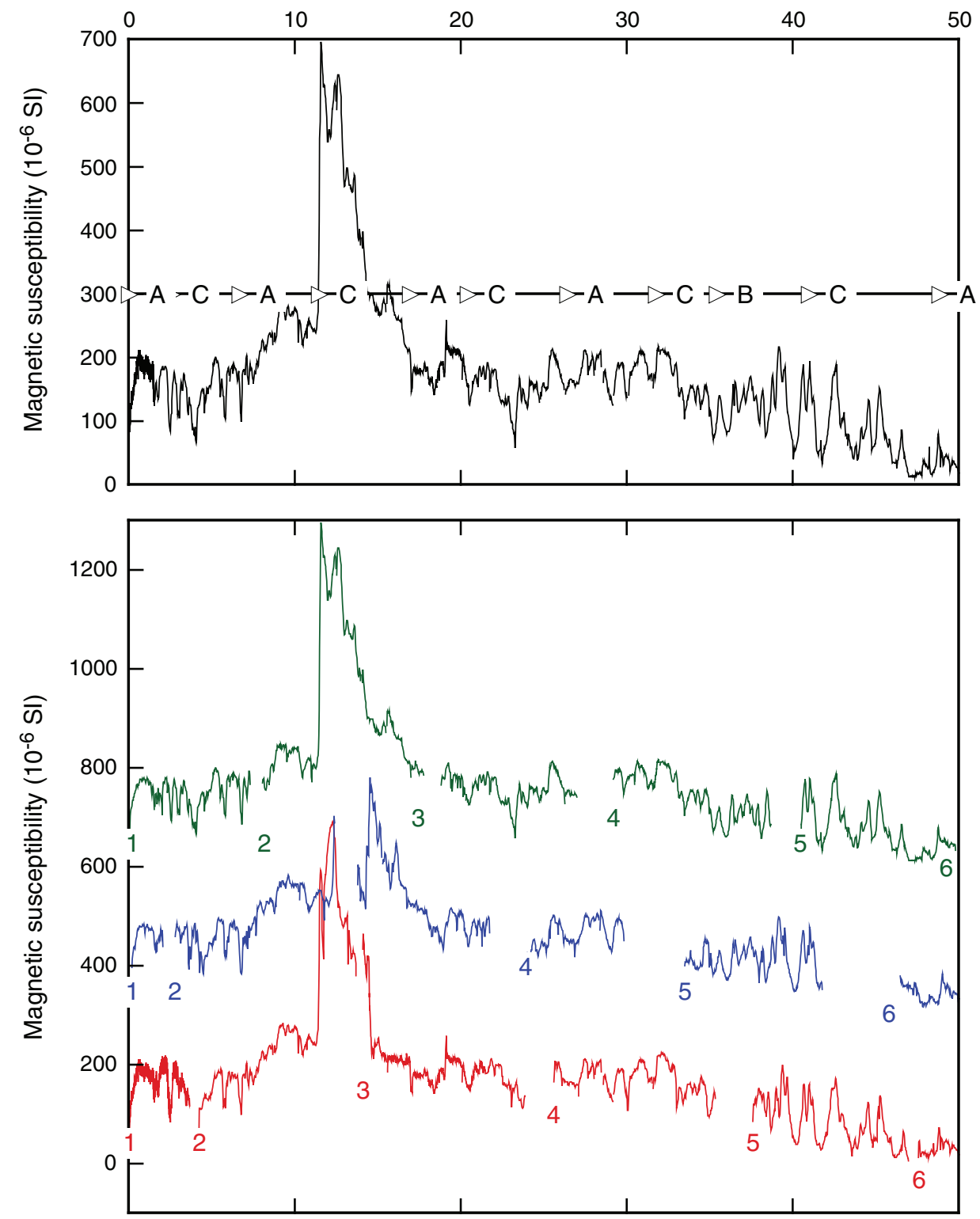
Figure F34 (continued). B. 50-100 CCSF-A. (Continued on next page.)
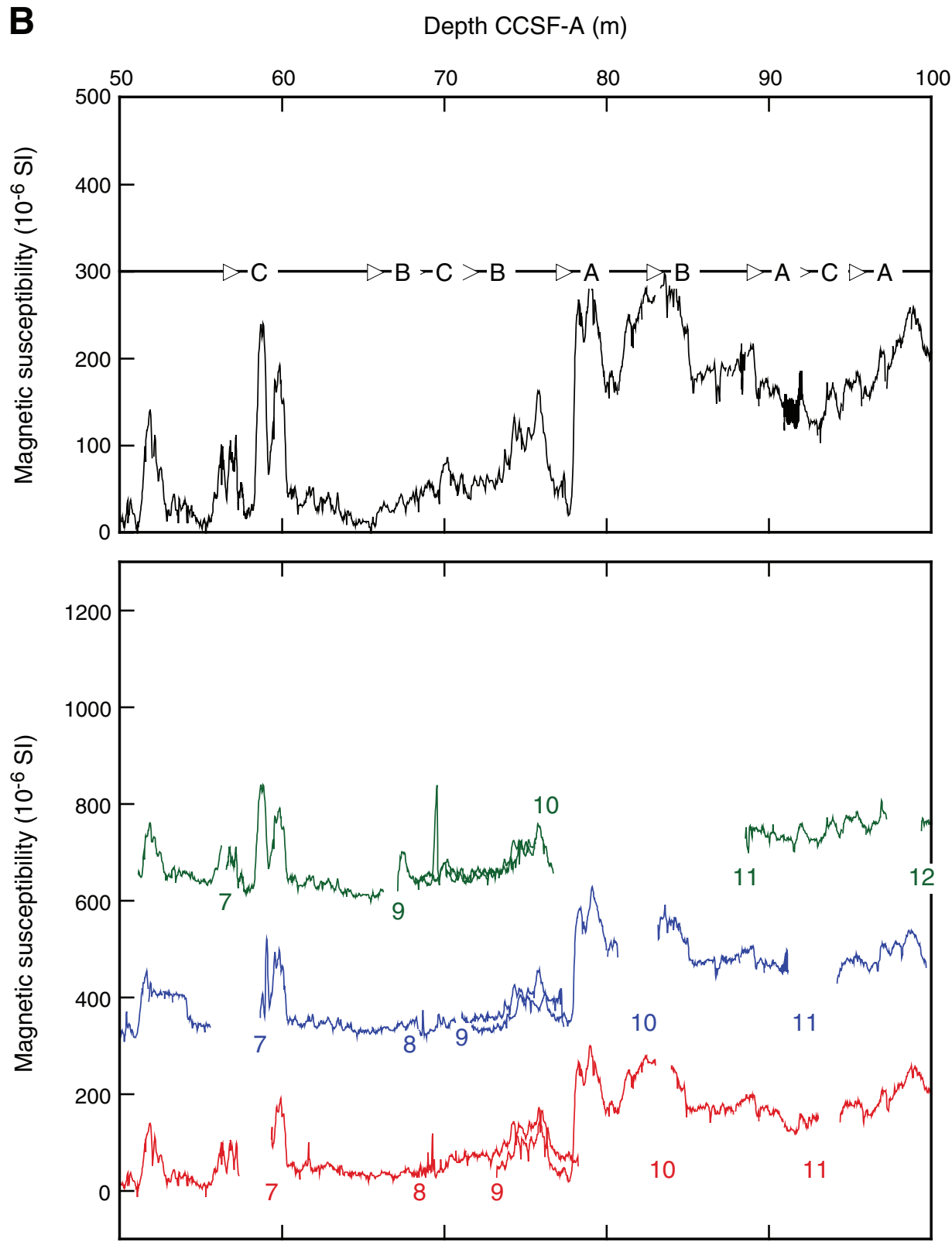
Figure F34 (continued). C. 100-150 CCSF-A. (Continued on next page.)
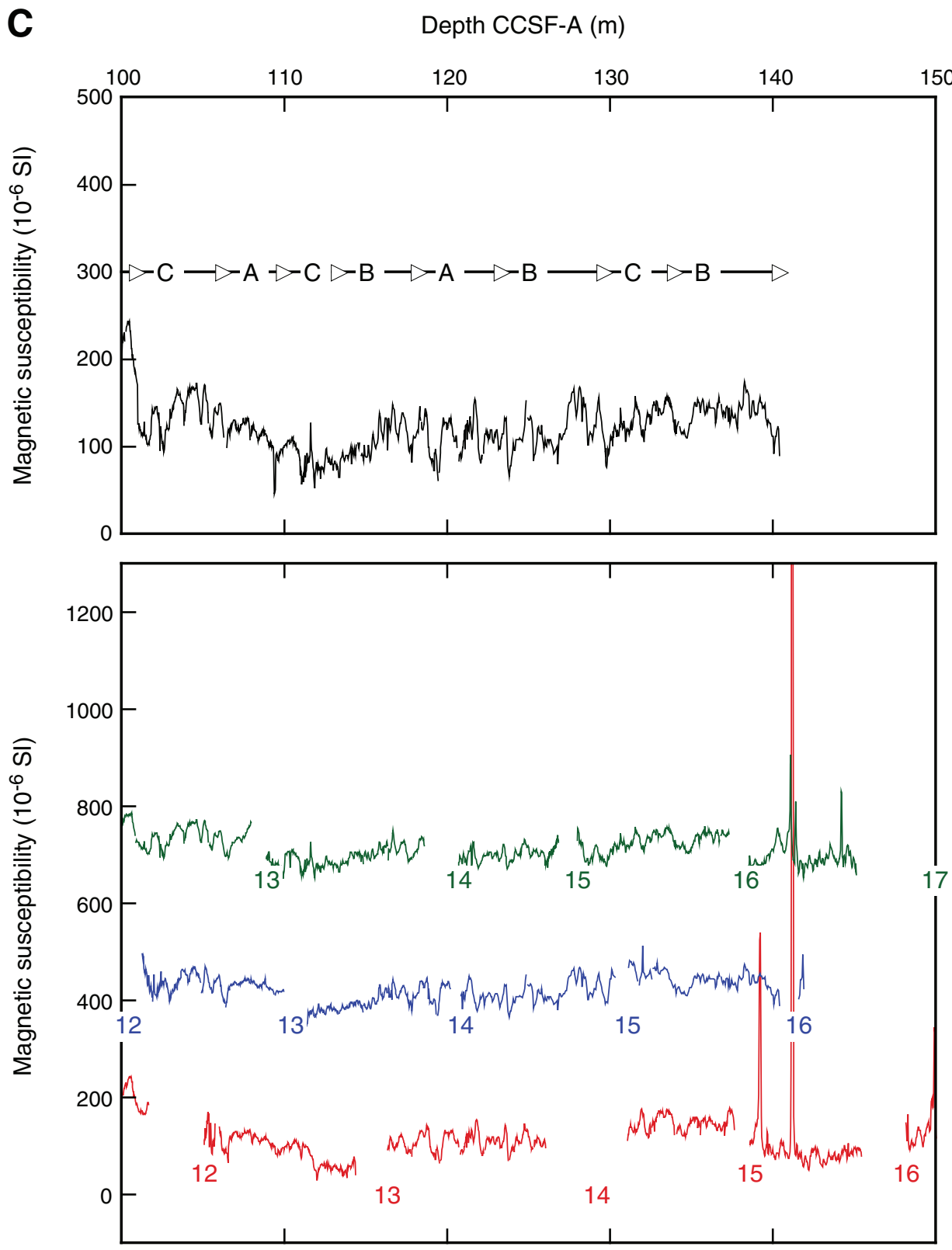
Figure F34 (continued). D. 150-200 CCSF-A.

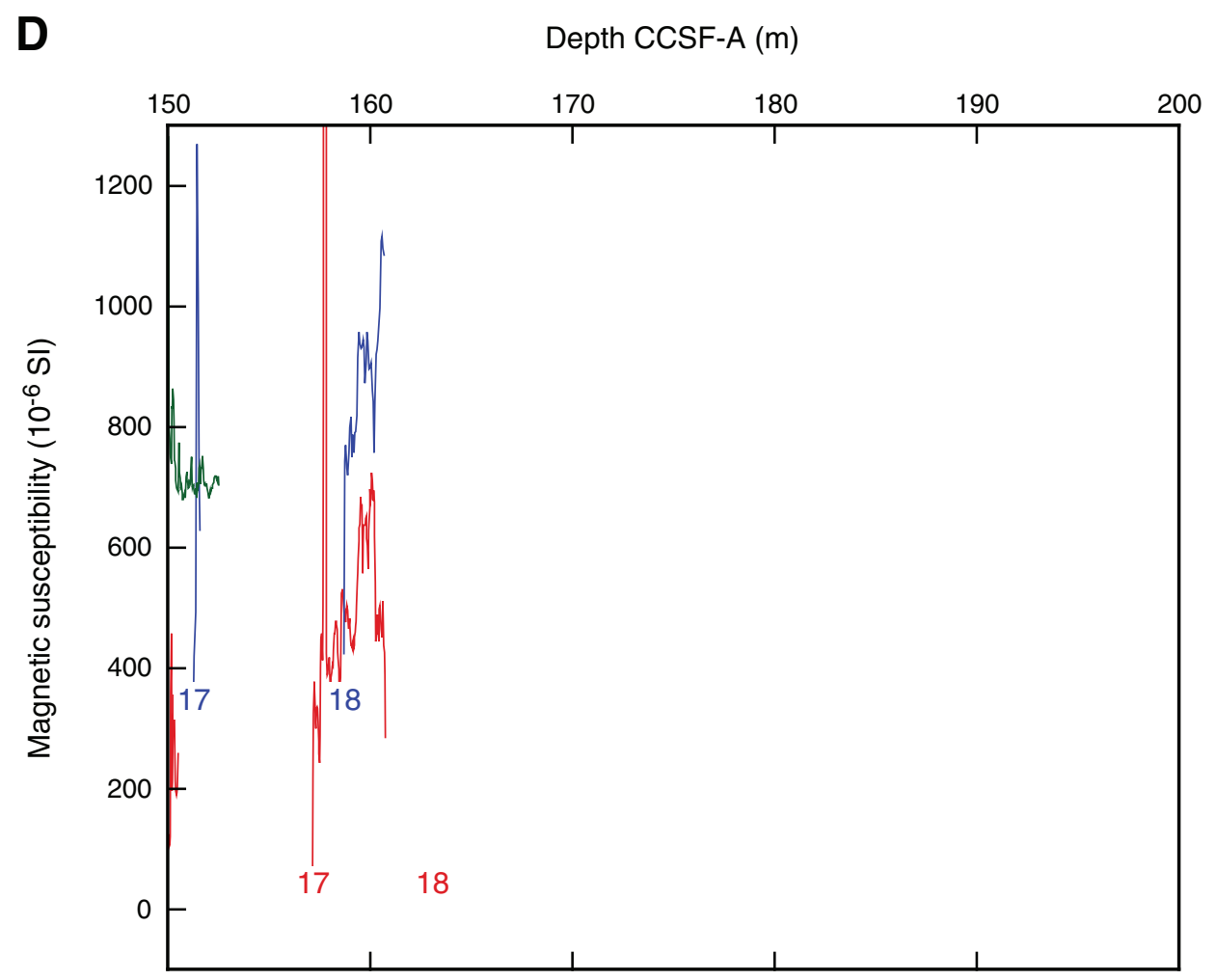


Figure F35. Magnetic susceptibility data, Site U1332. A. Magnetic susceptibility data from Cores 320-U1332A7H through $9 \mathrm{H}, 320-\mathrm{U} 1332 \mathrm{~B}-7 \mathrm{H}$ through $9 \mathrm{H}$, and 320-U1332C-7H through 9H. Note similar pattern in Cores $8 \mathrm{H}$ and $9 \mathrm{H}$ of each hole. B. Correlation of magnetic susceptibility data from Cores 320-U1332B-7H through $9 \mathrm{H}$ and 320-U1332C-7H through 9H to Cores 320-U1332A-7H through 9H, illustrating the actual sequence of sediment at U1332. Note gaps between Cores 320-U1332A-7H through 9H have been expanded artificially for straightforward correlation. C. Correlation of magnetic susceptibility data from Cores 320-U1332A-7H through 9H, 320-U1332B-7H through 9H, and 320-U1332C-7H through 9H to ODP Site 1220. The strong similarity between observed patterns allows for detailed correlation between all three holes and confirms duplication of sediments and recovery of a complete stratigraphic record. The sharp contact observed in Section 320-U1332C9H-2 (core image) marks the base of the duplicated interval.

A

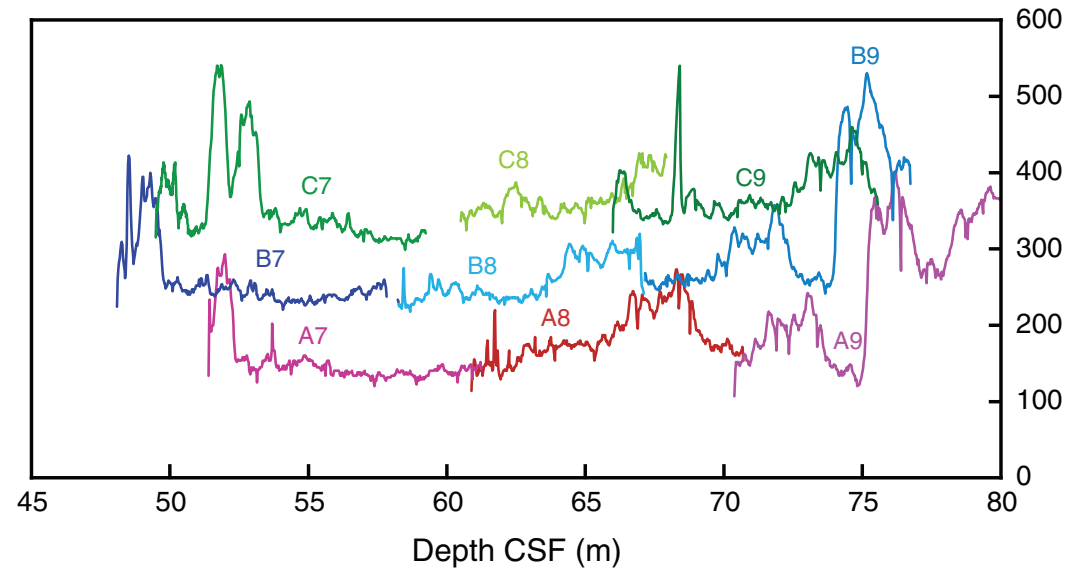

B
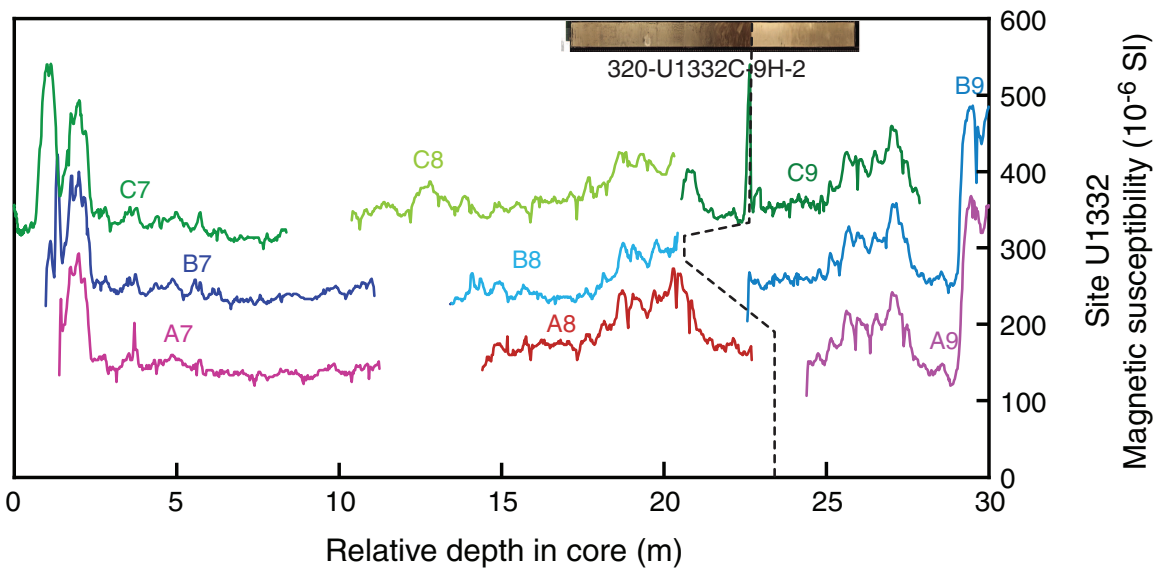

Relative depth in core (m)

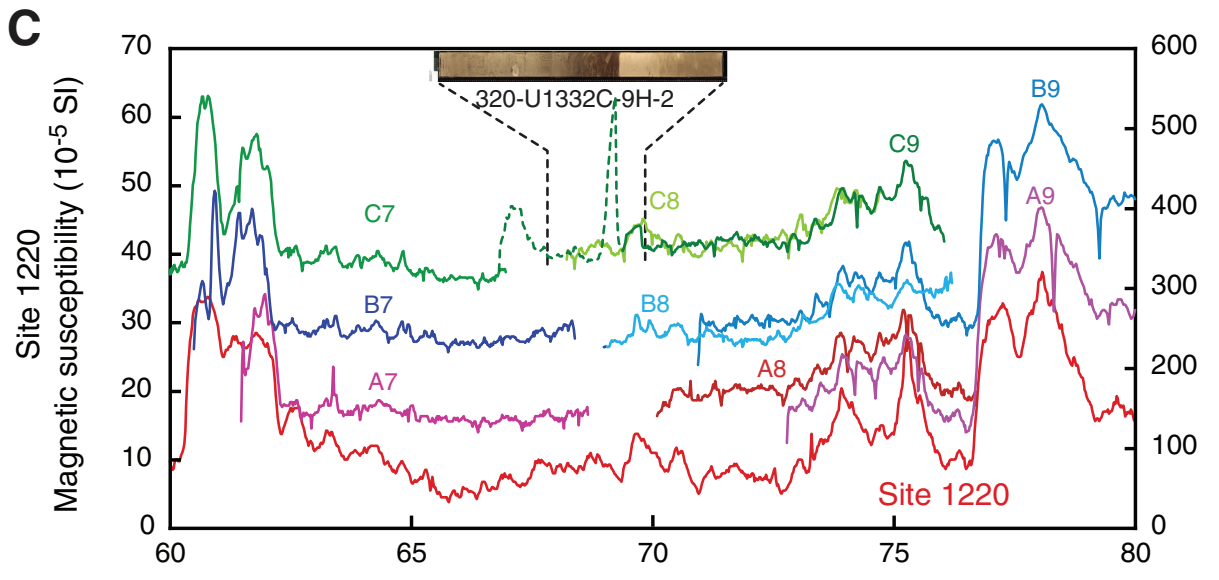

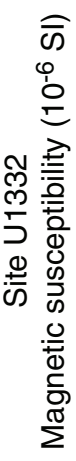

Site 1220 depth (rmcd) 
Figure F36. CSF depth vs. CCSF-A depth for tops of cores, Site U1332. Growth factor = slope of the regression line. On average, CCSF-A depth of spliced section is 10\% greater than CSF depth.

Depth CCSF-A (m)

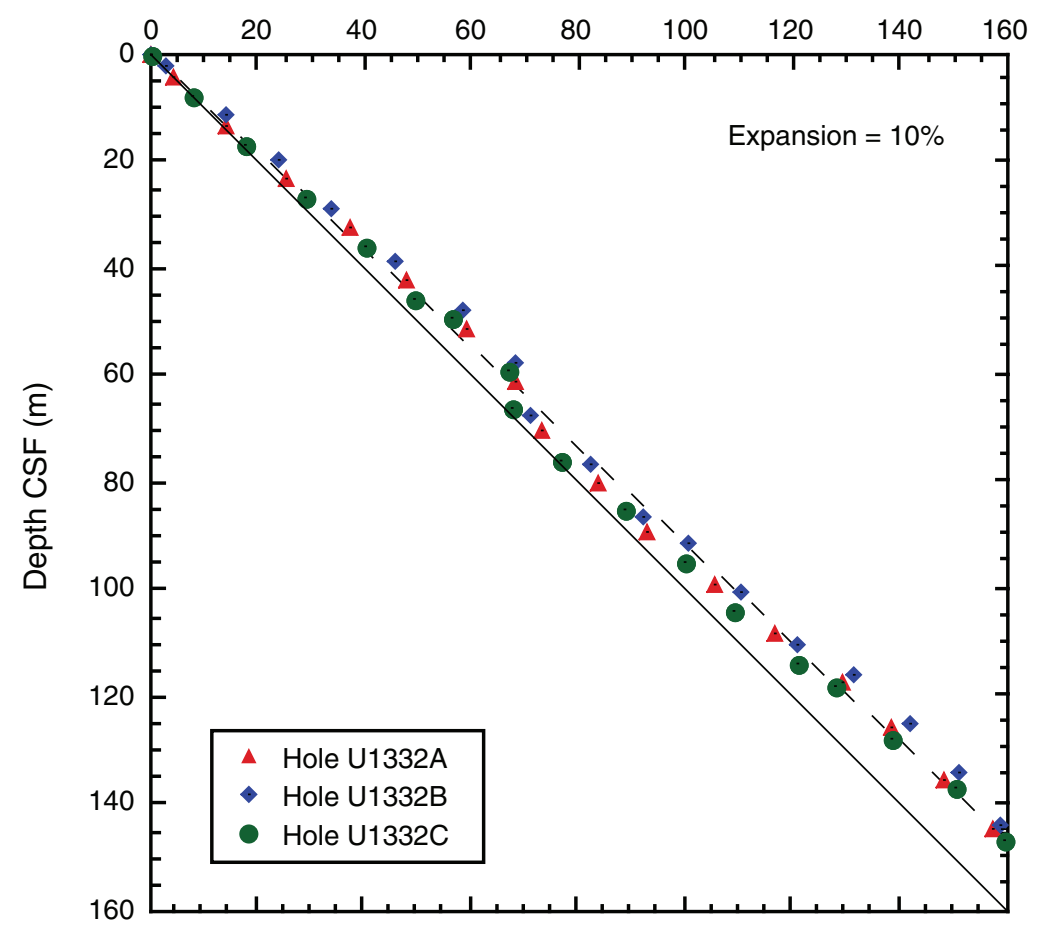


Figure F37. Logging operations summary diagram. A. Modified triple combination tool string run in Hole 1332A. B. Depth intervals of downlog and two upward passes. HNGS = Hostile Environment Gamma Ray Sonde, HLDS = Hostile Environment Litho-Density Sonde, MSS = Magnetic Susceptibility Sonde.
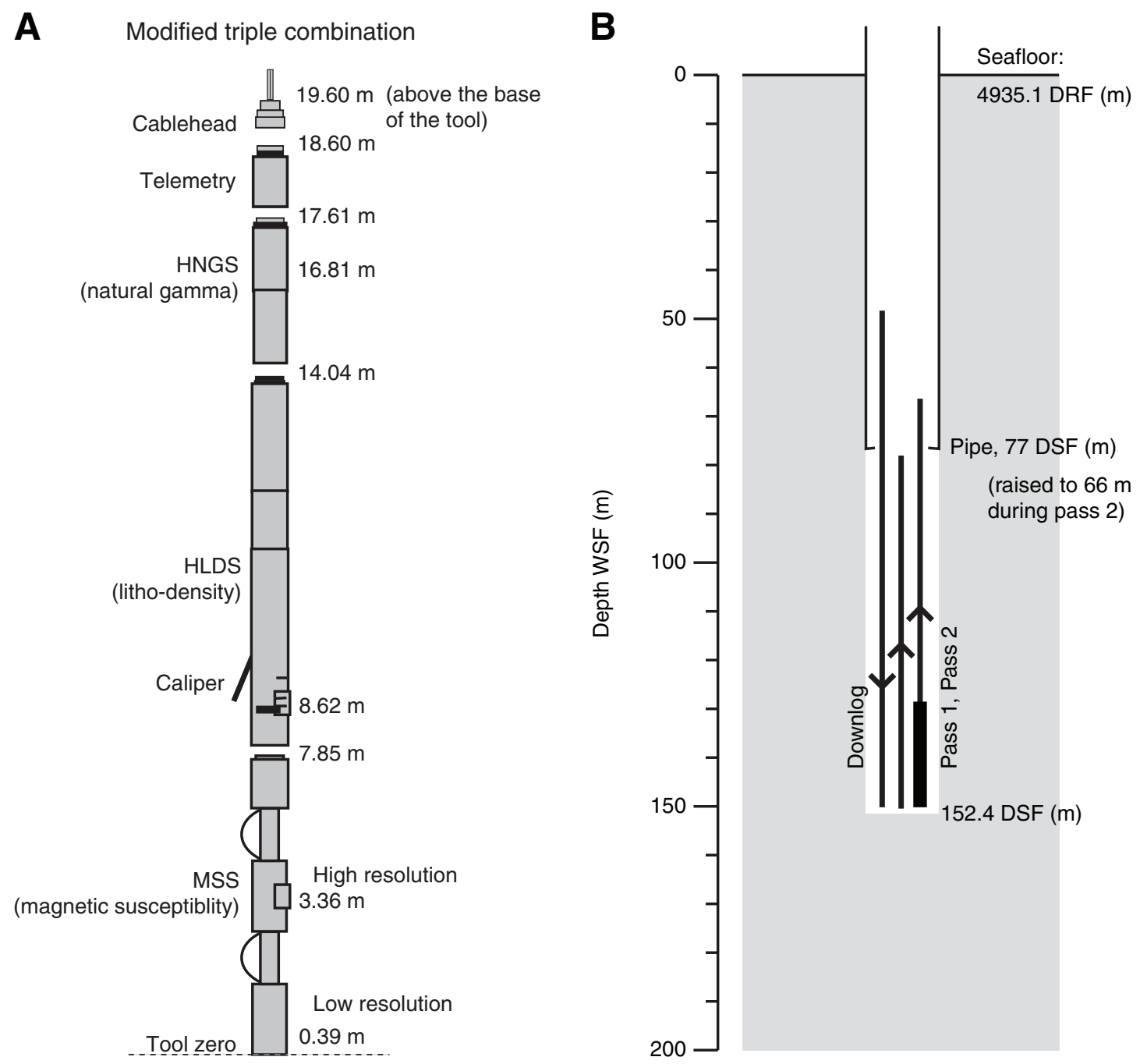
Figure F38. Downhole logs, Hole U1332A. Logging units are described in text. Unit 1 is characterized by alternating radiolarian and nannofossil oozes with higher density and photoelectric effect (PEF) in the nannofossil oozes. Uncal. $=$ uncalibrated.
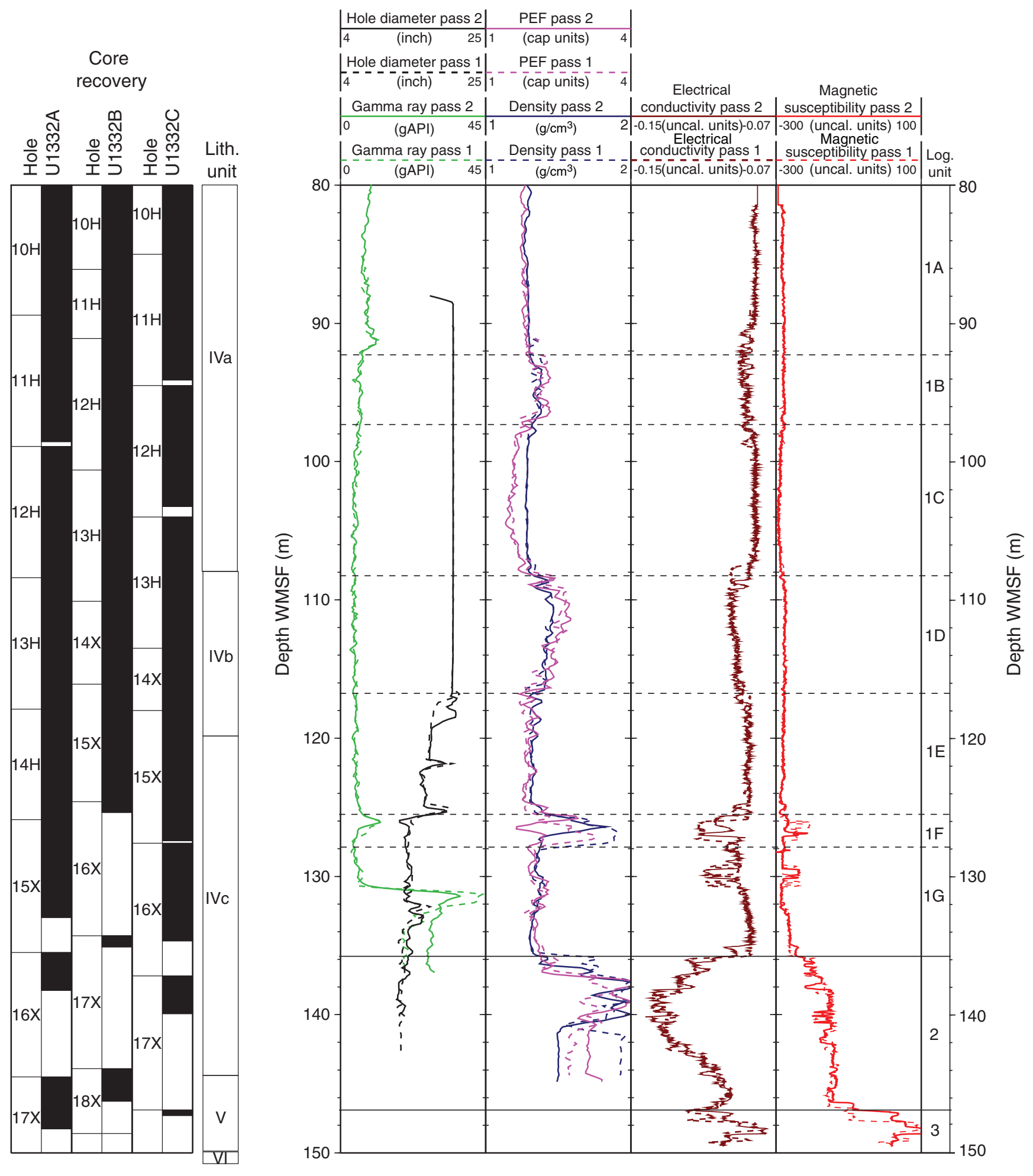
Figure F39. Natural gamma radiation data, Hole U1332A. A large peak in uranium and potassium occurs at $\sim 130 \mathrm{~m}$ WMSF.
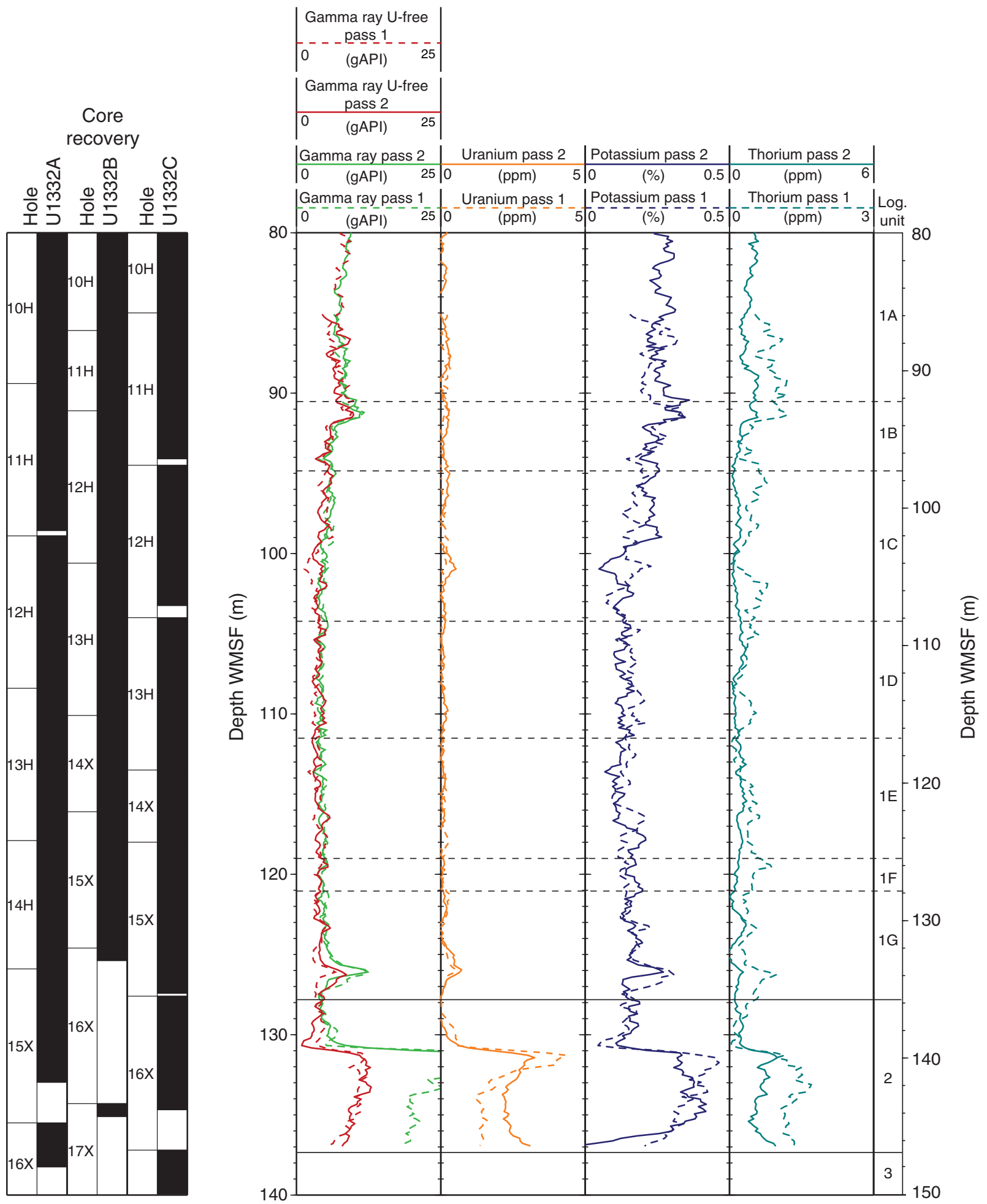
Figure F40. Heat flow calculation, Hole U1332A. A. Sediment temperatures. B. Thermal resistance based on laboratory thermal conductivity data. C. Bullard plot where heat flow is calculated from a linear fit of the temperature data. APCT-3 = advanced piston corer temperature tool.

A APCT-3 temperature $\left({ }^{\circ} \mathrm{C}\right)$

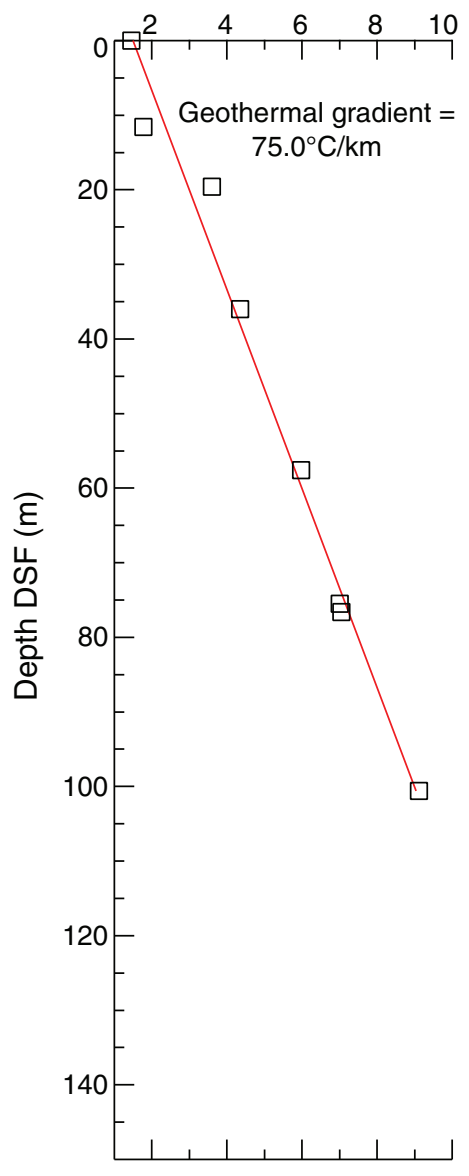

B Thermal resistance $\left(\mathrm{m}^{2} \mathrm{~K} / \mathrm{W}\right)$

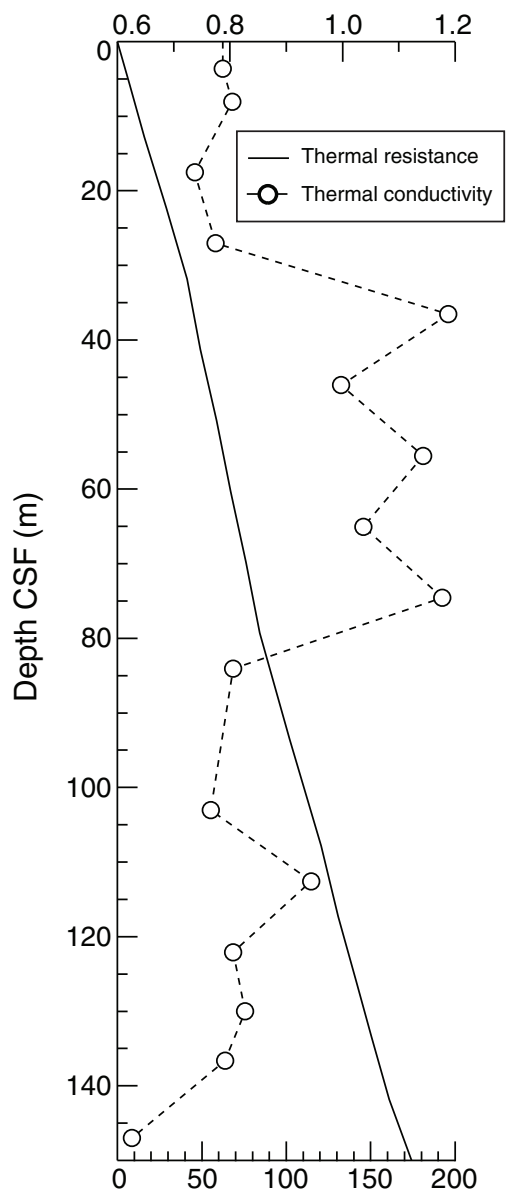

Thermal conductivity $(\mathrm{W} /[\mathrm{m} \cdot \mathrm{K}])$
C APCT-3 temperature $\left({ }^{\circ} \mathrm{C}\right)$

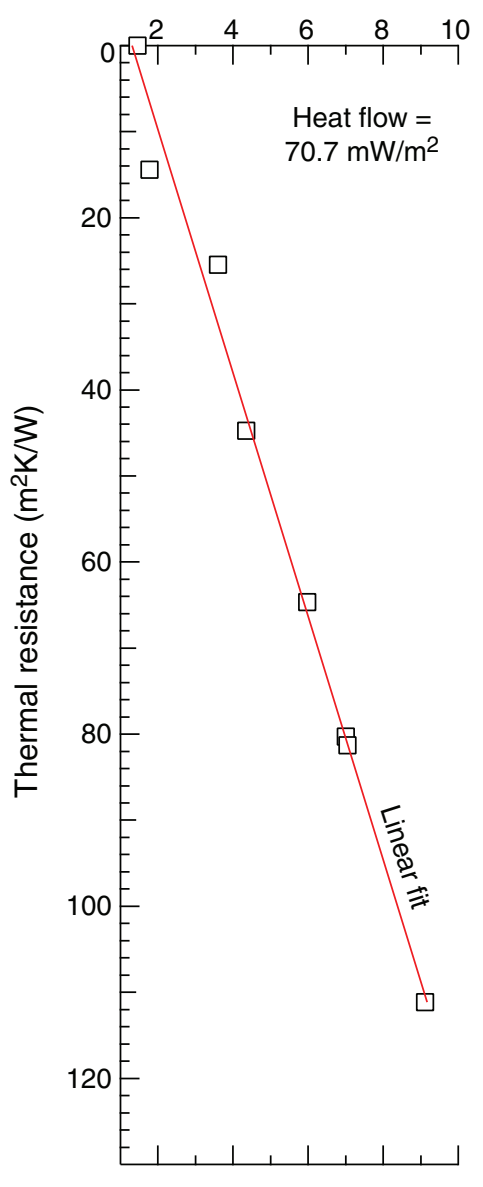


Table T1. Coring summary, Site U1332. (See table notes.) (Continued on next page.)

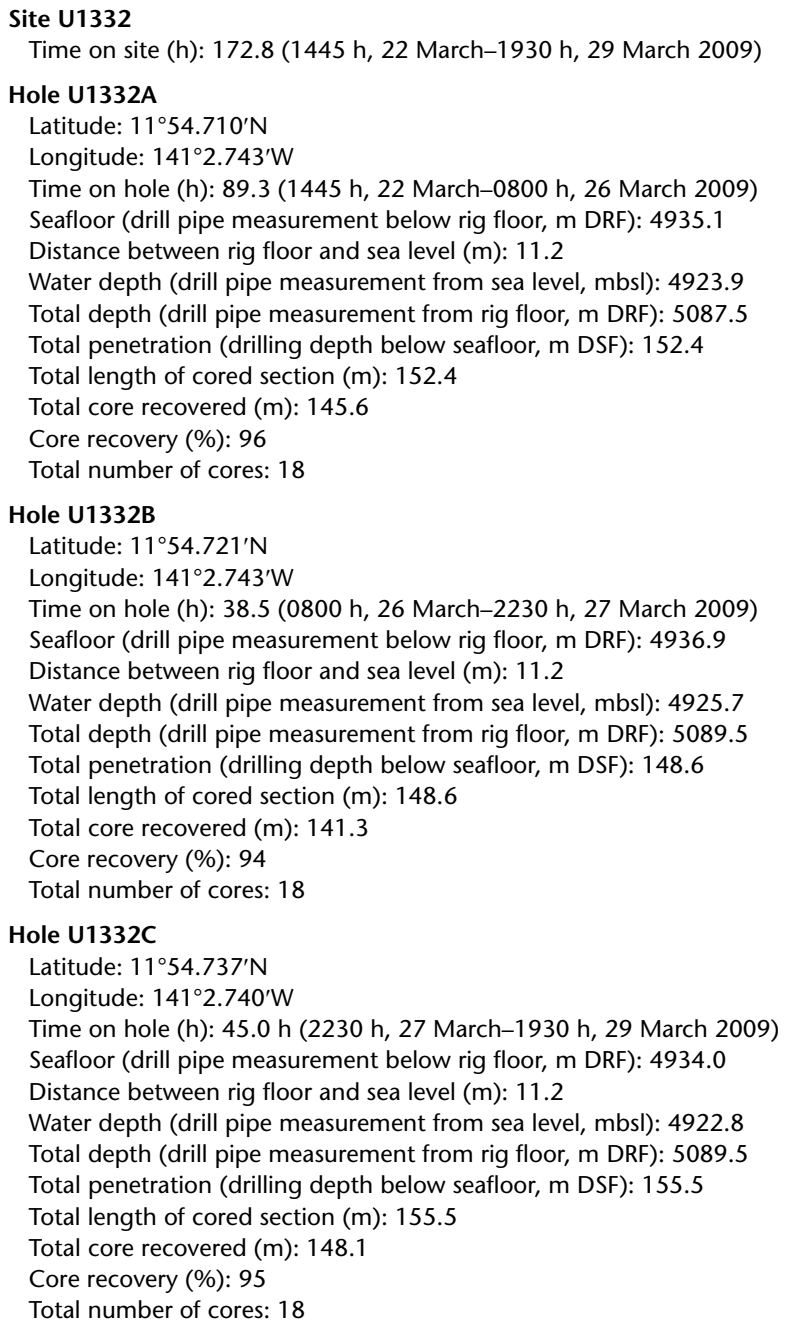

\begin{tabular}{|c|c|c|c|c|c|c|c|c|c|}
\hline \multirow[b]{2}{*}{ Core } & \multirow[b]{2}{*}{$\begin{array}{l}\text { Date } \\
\text { (2009) }\end{array}$} & \multirow[b]{2}{*}{$\begin{array}{l}\text { Local time } \\
\text { (h) }\end{array}$} & \multicolumn{2}{|c|}{ Depth DSF (m) } & \multirow[b]{2}{*}{$\begin{array}{l}\text { Interval } \\
\text { advanced } \\
(\mathrm{m})\end{array}$} & \multicolumn{2}{|c|}{ Depth CSF (m) } & \multirow[b]{2}{*}{$\begin{array}{l}\text { Length of core } \\
\text { recovered } \\
\text { (m) }\end{array}$} & \multirow[b]{2}{*}{$\begin{array}{c}\text { Recovery } \\
\text { (\%) }\end{array}$} \\
\hline & & & $\begin{array}{l}\text { Top of } \\
\text { cored } \\
\text { interval }\end{array}$ & $\begin{array}{l}\text { Bottom of } \\
\text { cored } \\
\text { interval }\end{array}$ & & $\begin{array}{l}\text { Top of } \\
\text { cored } \\
\text { interval }\end{array}$ & $\begin{array}{l}\text { Bottom of } \\
\text { cored } \\
\text { interval }\end{array}$ & & \\
\hline \multicolumn{10}{|c|}{ 320-U1332A- } \\
\hline $1 \mathrm{H}$ & $23 \mathrm{Mar}$ & 1125 & 0.0 & 3.9 & 3.9 & 0.0 & 3.91 & 3.91 & 100 \\
\hline $2 \mathrm{H}$ & $23 \mathrm{Mar}$ & 1245 & 3.9 & 13.4 & 9.5 & 3.9 & 13.67 & 9.77 & 103 \\
\hline $3 \mathrm{H}$ & $23 \mathrm{Mar}$ & 1440 & 13.4 & 22.9 & 9.5 & 13.4 & 23.56 & 10.16 & 107 \\
\hline $4 \mathrm{H}$ & $23 \mathrm{Mar}$ & 1550 & 22.9 & 32.4 & 9.5 & 22.9 & 33.00 & 10.10 & 106 \\
\hline $5 \mathrm{H}$ & $23 \mathrm{Mar}$ & 1710 & 32.4 & 41.9 & 9.5 & 32.4 & 42.52 & 10.12 & 107 \\
\hline $6 \mathrm{H}$ & $23 \mathrm{Mar}$ & 1835 & 41.9 & 51.4 & 9.5 & 41.9 & 52.02 & 10.12 & 107 \\
\hline $7 \mathrm{H}$ & $23 \mathrm{Mar}$ & 1950 & 51.4 & 60.9 & 9.5 & 51.4 & 61.54 & 10.14 & 107 \\
\hline $8 \mathrm{H}$ & $23 \mathrm{Mar}$ & 2110 & 60.9 & 70.4 & 9.5 & 60.9 & 71.05 & 10.15 & 107 \\
\hline $9 \mathrm{H}$ & $23 \mathrm{Mar}$ & 2220 & 70.4 & 79.9 & 9.5 & 70.4 & 80.52 & 10.12 & 107 \\
\hline $10 \mathrm{H}$ & $23 \mathrm{Mar}$ & 2335 & 79.9 & 89.4 & 9.5 & 79.9 & 89.94 & 10.04 & 106 \\
\hline $11 \mathrm{H}$ & $24 \mathrm{Mar}$ & 0100 & 89.4 & 98.9 & 9.5 & 89.4 & 98.57 & 9.17 & 97 \\
\hline $12 \mathrm{H}$ & $24 \mathrm{Mar}$ & 0240 & 98.9 & 108.4 & 9.5 & 98.9 & 108.50 & 9.60 & 101 \\
\hline $13 \mathrm{H}$ & $24 \mathrm{Mar}$ & 0410 & 108.4 & 117.9 & 9.5 & 108.4 & 118.43 & 10.03 & 106 \\
\hline $14 \mathrm{H}$ & $24 \mathrm{Mar}$ & 0610 & 117.9 & 125.9 & 8.0 & 117.9 & 126.33 & 8.43 & 105 \\
\hline $15 X$ & $24 \mathrm{Mar}$ & 0835 & 125.9 & 135.5 & 9.6 & 125.9 & 132.98 & 7.08 & 74 \\
\hline $16 X$ & $24 \mathrm{Mar}$ & 1045 & 135.5 & 144.5 & 9.0 & 135.5 & 138.25 & 2.75 & 31 \\
\hline $17 x$ & $24 \mathrm{Mar}$ & 1300 & 144.5 & 150.4 & 5.9 & 144.5 & 148.26 & 3.76 & 64 \\
\hline \multirow[t]{3}{*}{$18 \mathrm{X}$} & $24 \mathrm{Mar}$ & 1515 & 150.4 & 152.4 & 2.0 & 150.4 & 150.56 & 0.16 & 8 \\
\hline & & & \multicolumn{2}{|c|}{ Advanced total: } & 152.4 & & & 145.6 & 96 \\
\hline & & & \multicolumn{2}{|c|}{ Total interval cored: } & 152.4 & & & & \\
\hline
\end{tabular}


Table T1 (continued).

\begin{tabular}{|c|c|c|c|c|c|c|c|c|c|}
\hline \multirow[b]{2}{*}{ Core } & \multirow[b]{2}{*}{$\begin{array}{c}\text { Date } \\
(2009)\end{array}$} & \multirow[b]{2}{*}{$\begin{array}{l}\text { Local time } \\
\text { (h) }\end{array}$} & \multicolumn{2}{|c|}{ Depth DSF (m) } & \multirow[b]{2}{*}{$\begin{array}{l}\text { Interval } \\
\text { advanced } \\
(\mathrm{m})\end{array}$} & \multicolumn{2}{|c|}{ Depth CSF (m) } & \multirow[b]{2}{*}{$\begin{array}{l}\text { Length of core } \\
\text { recovered } \\
\text { (m) }\end{array}$} & \multirow[b]{2}{*}{$\begin{array}{l}\text { Recovery } \\
\text { (\%) }\end{array}$} \\
\hline & & & $\begin{array}{l}\text { Top of } \\
\text { cored } \\
\text { interval }\end{array}$ & $\begin{array}{l}\text { Bottom of } \\
\text { cored } \\
\text { interval }\end{array}$ & & $\begin{array}{l}\text { Top of } \\
\text { cored } \\
\text { interval }\end{array}$ & $\begin{array}{c}\text { Bottom of } \\
\text { cored } \\
\text { interval }\end{array}$ & & \\
\hline \multicolumn{10}{|c|}{ 320-U1332B- } \\
\hline $1 \mathrm{H}$ & $26 \mathrm{Mar}$ & 1300 & 0.0 & 2.10 & 2.1 & 0.00 & 2.10 & 2.10 & 100 \\
\hline $2 \mathrm{H}$ & $26 \mathrm{Mar}$ & 1500 & 2.1 & 11.60 & 9.5 & 2.10 & 12.14 & 10.04 & 106 \\
\hline $3 \mathrm{H}$ & $26 \mathrm{Mar}$ & 1630 & 11.6 & 19.60 & 8.0 & 11.60 & 21.52 & 8.42 & 124 \\
\hline $4 \mathrm{H}$ & $26 \mathrm{Mar}$ & 1800 & 19.6 & 29.10 & 9.5 & 19.60 & 29.66 & 10.06 & 106 \\
\hline $5 \mathrm{H}$ & $26 \mathrm{Mar}$ & 1930 & 29.1 & 38.60 & 9.5 & 29.10 & 37.68 & 8.58 & 90 \\
\hline $6 \mathrm{H}$ & $26 \mathrm{Mar}$ & 2235 & 38.6 & 48.10 & 9.5 & 38.60 & 48.55 & 9.95 & 105 \\
\hline $7 \mathrm{H}$ & $27 \mathrm{Mar}$ & 0025 & 48.1 & 57.60 & 9.5 & 48.10 & 58.10 & 10.00 & 105 \\
\hline $8 \mathrm{H}$ & $27 \mathrm{Mar}$ & 0310 & 57.6 & 67.10 & 9.5 & 57.60 & 67.30 & 9.70 & 102 \\
\hline $9 \mathrm{H}$ & $27 \mathrm{Mar}$ & 0530 & 67.1 & 76.60 & 9.5 & 67.10 & 77.12 & 10.02 & 105 \\
\hline $10 \mathrm{H}$ & $27 \mathrm{Mar}$ & 0700 & 76.6 & 86.10 & 9.5 & 76.60 & 86.69 & 10.09 & 106 \\
\hline $11 \mathrm{H}$ & $27 \mathrm{Mar}$ & 0830 & 86.1 & 91.10 & 5.0 & 86.10 & 93.87 & 7.77 & 155 \\
\hline $12 \mathrm{H}$ & $27 \mathrm{Mar}$ & 1020 & 91.1 & 100.60 & 9.5 & 91.10 & 101.06 & 9.96 & 105 \\
\hline $13 \mathrm{H}$ & $27 \mathrm{Mar}$ & 1215 & 100.6 & 110.10 & 9.5 & 100.60 & 110.81 & 10.21 & 107 \\
\hline $14 X$ & 27 Mar & 1345 & 110.1 & 116.10 & 6.0 & 110.10 & 119.83 & 9.73 & 162 \\
\hline $15 X$ & $27 \mathrm{Mar}$ & 1515 & 116.1 & 124.60 & 8.5 & 116.10 & 125.82 & 9.72 & 114 \\
\hline $16 X$ & $27 \mathrm{Mar}$ & 1645 & 124.6 & 134.30 & 9.7 & 124.60 & 125.39 & 0.79 & 8 \\
\hline $17 X$ & $27 \mathrm{Mar}$ & 1850 & 134.3 & 143.90 & 9.6 & 134.30 & 135.11 & 0.78 & 8 \\
\hline \multirow[t]{3}{*}{$18 x$} & $27 \mathrm{Mar}$ & 2055 & 143.9 & 148.60 & 4.7 & 143.90 & 146.26 & 2.36 & 50 \\
\hline & & & \multirow{2}{*}{\multicolumn{2}{|c|}{$\begin{array}{l}\text { Advanced total: } \\
\text { Total interval cored: }\end{array}$}} & 148.6 & & & 140.28 & 94 \\
\hline & & & & & 148.6 & & & & \\
\hline \multicolumn{10}{|c|}{ 320-U1332C- } \\
\hline $1 \mathrm{H}$ & $28 \mathrm{Mar}$ & 0135 & 0.0 & 7.50 & 7.5 & 0.00 & 7.49 & 7.49 & 100 \\
\hline $2 \mathrm{H}$ & $28 \mathrm{Mar}$ & 0300 & 7.5 & 17.00 & 9.5 & 7.50 & 17.48 & 9.98 & 105 \\
\hline $3 \mathrm{H}$ & $28 \mathrm{Mar}$ & 0415 & 17.0 & 26.50 & 9.5 & 17.00 & 26.96 & 9.96 & 105 \\
\hline $4 \mathrm{H}$ & $28 \mathrm{Mar}$ & 0550 & 26.5 & 36.00 & 9.5 & 26.50 & 36.55 & 10.05 & 106 \\
\hline $5 \mathrm{H}$ & $28 \mathrm{Mar}$ & 0730 & 36.0 & 45.50 & 9.5 & 36.00 & 45.79 & 9.79 & 103 \\
\hline $6 \mathrm{H}$ & $28 \mathrm{Mar}$ & 0850 & 45.5 & 49.50 & 4.0 & 45.50 & 53.07 & 7.57 & 189 \\
\hline $7 \mathrm{H}$ & $28 \mathrm{Mar}$ & 1000 & 49.5 & 59.00 & 9.5 & 49.50 & 59.46 & 9.96 & 105 \\
\hline $8 \mathrm{H}$ & $28 \mathrm{Mar}$ & 1115 & 59.0 & 66.00 & 7.0 & 59.00 & 68.22 & 9.22 & 132 \\
\hline $9 \mathrm{H}$ & $28 \mathrm{Mar}$ & 1255 & 66.0 & 75.50 & 9.5 & 66.00 & 75.96 & 9.96 & 105 \\
\hline $10 \mathrm{H}$ & $28 \mathrm{Mar}$ & 1815 & 75.5 & 85.00 & 9.5 & 75.50 & 85.58 & 10.08 & 106 \\
\hline $11 \mathrm{H}$ & $28 \mathrm{Mar}$ & 2030 & 85.0 & 94.50 & 9.5 & 85.00 & 94.10 & 9.10 & 96 \\
\hline $12 \mathrm{H}$ & $28 \mathrm{Mar}$ & 2150 & 94.5 & 104.00 & 9.5 & 94.50 & 103.25 & 8.75 & 92 \\
\hline $13 \mathrm{H}$ & $28 \mathrm{Mar}$ & 2315 & 104.0 & 113.50 & 9.5 & 104.00 & 114.13 & 10.13 & 107 \\
\hline $14 X$ & $29 \mathrm{Mar}$ & 0040 & 113.5 & 118.00 & 4.5 & 113.50 & 119.88 & 6.38 & 142 \\
\hline $15 X$ & $29 \mathrm{Mar}$ & 0215 & 118.0 & 127.60 & 9.6 & 118.00 & 127.43 & 9.43 & 98 \\
\hline $16 X$ & $29 \mathrm{Mar}$ & 0350 & 127.6 & 137.20 & 9.6 & 127.60 & 134.67 & 7.07 & 74 \\
\hline $17 X$ & $29 \mathrm{Mar}$ & 0600 & 137.2 & 146.90 & 9.7 & 137.20 & 139.94 & 2.74 & 28 \\
\hline \multirow[t]{3}{*}{$18 x$} & $29 \mathrm{Mar}$ & 0810 & 146.9 & 155.50 & 8.6 & 146.90 & 147.30 & 0.40 & 5 \\
\hline & & & \multicolumn{2}{|c|}{ Advanced total: } & 155.5 & & & 148.06 & 95 \\
\hline & & & \multicolumn{2}{|c|}{ Total interval cored: } & 155.5 & & & & \\
\hline
\end{tabular}

Notes: $\mathrm{DRF}=$ drilling depth below rig floor, $\mathrm{DSF}=$ drilling depth below seafloor, $\mathrm{CSF}=$ core depth below seafloor. $\mathrm{H}=\mathrm{APC}$ core, $\mathrm{X}=\mathrm{XCB}$ core. Local time $=$ UTC $-10 \mathrm{~h}$.

Table T2. Lithologic unit boundaries, Site U1332. (See table notes.)

\begin{tabular}{lcccccc}
\hline Unit & $\begin{array}{c}\text { Core, section, } \\
\text { interval }(\mathrm{cm})\end{array}$ & $\begin{array}{c}\text { Depth } \\
\text { CSF }(\mathrm{m})\end{array}$ & $\begin{array}{c}\text { Core, section, } \\
\text { interval }(\mathrm{cm})\end{array}$ & $\begin{array}{c}\text { Depth } \\
\text { CSF }(\mathrm{m})\end{array}$ & $\begin{array}{c}\text { Core, section, } \\
\text { interval }(\mathrm{cm})\end{array}$ & $\begin{array}{c}\text { Depth } \\
\text { CSF }(\mathrm{m})\end{array}$ \\
\hline & $320-\mathrm{U} 1331 \mathrm{~A}-$ & & $320-\mathrm{U} 1331 \mathrm{~B}-$ & & $320-\mathrm{U} 1331 \mathrm{C}-$ & \\
I & $3 \mathrm{H}-3,130$ & 17.7 & $3 \mathrm{H}-4,150$ & 17.6 & $3 \mathrm{H}-1,70$ & 17.7 \\
II & $5 \mathrm{H}-1,150$ & 33.9 & $5 \mathrm{H}-1,150$ & 30.6 & $4 \mathrm{H}-7,30$ & 35.8 \\
III & $9 \mathrm{H}-4,124$ & 76.14 & $9 \mathrm{H}-6,50$ & 75.1 & $10 \mathrm{H}-1,41$ & 75.91 \\
IVa & $13 \mathrm{H}-1,20$ & 108.6 & $13 \mathrm{H}-5,120$ & 107.8 & $13 \mathrm{H}-2,150$ & 107 \\
IVb & $14 \mathrm{H}-1,150$ & 119.4 & $15 \mathrm{H}-4,40$ & 121 & $15 \mathrm{H}-2,50$ & 120 \\
IVc & $16 \mathrm{X}-\mathrm{CC}, 42^{*}$ & $138.29^{*}$ & $17 \mathrm{X}-\mathrm{CC}, 40^{*}$ & $135.08^{*}$ & $17 \mathrm{X}-2,7^{*}$ & $138.77^{*}$ \\
V & $17 \mathrm{X}-\mathrm{CC}, 3$ & 148.15 & $18 \mathrm{X}-\mathrm{CC}, 16$ & 146.09 & $18 \mathrm{XX}-\mathrm{CC}, 46$ & 147.36 \\
VI & $18 \mathrm{X}-\mathrm{CC}, 52^{*}$ & $150.56^{*}$ & $18 \mathrm{X}-\mathrm{CC}, 34^{*}$ & $146.27^{*}$ & $18 \mathrm{X}-\mathrm{CC}, 62^{*}$ & $147.52^{*}$ \\
\hline
\end{tabular}

Notes: Interval/depth are given for basal boundary of each unit. * = unit extends through at least given interval and depth, but boundary was not cored. 
Table T3. Calcareous nannofossil datums, Site U1332. (See table note.)

\begin{tabular}{|c|c|c|c|c|c|c|c|}
\hline \multicolumn{2}{|c|}{ Core, section, interval $(\mathrm{cm})$} & \multirow[b]{2}{*}{ Marker species } & \multirow{2}{*}{$\begin{array}{c}\text { Age } \\
\text { (Ma) }\end{array}$} & \multicolumn{4}{|c|}{ Depth CSF (m) } \\
\hline Top & Bottom & & & Top & Bottom & Midpoint & \pm \\
\hline $\begin{array}{c}320-U 1332 \mathrm{~A}- \\
3 \mathrm{H}-4,100\end{array}$ & $\begin{array}{c}320-U 1332 \mathrm{~A}- \\
3 \mathrm{H}-5,100\end{array}$ & T Triquetrorhabdulus carinatus & 18.28 & 18.90 & 20.40 & 19.65 & 0.75 \\
\hline $3 \mathrm{H}-7,60$ & $3 \mathrm{H}-\mathrm{CC}$ & T Sphenolithus delphix & 23.1 & 23.00 & 23.51 & 23.26 & 0.26 \\
\hline $3 \mathrm{H}-\mathrm{CC}$ & $4 \mathrm{H}-2,60$ & B Sphenolithus delphix & 23.2 & 23.51 & 23.50 & 23.51 & 0.01 \\
\hline $4 \mathrm{H}-2,60$ & $4 \mathrm{H}-3,60$ & X T. longus/T. carinatus & 24.7 & 25.00 & 26.50 & 25.75 & 0.75 \\
\hline $4 \mathrm{H}-2,60$ & $4 \mathrm{H}-3,60$ & Tc C. abisectus & 24.7 & 25.00 & 26.50 & 25.75 & 0.75 \\
\hline $4 \mathrm{H}-\mathrm{CC}$ & $5 \mathrm{H}-1,80$ & T Sphenolithus predistentus & 26.9 & 32.95 & 33.20 & 33.08 & 0.13 \\
\hline $5 \mathrm{H}-3,80$ & $5 \mathrm{H}-4,80$ & T Sphenolithus pseudoradians & 28.8 & 36.20 & 37.70 & 36.95 & 0.75 \\
\hline $6 \mathrm{H}-5,70$ & $6 \mathrm{H}-6,70$ & B Sphenolithus distentus & 30.0 & 48.60 & 50.10 & 49.35 & 0.75 \\
\hline $7 \mathrm{H}-6,80$ & $7 \mathrm{H}-7,80$ & T Reticulofenestra umbilicus & 32.0 & 59.69 & 61.18 & 60.44 & 0.75 \\
\hline $8 \mathrm{H}-4,50$ & $8 \mathrm{H}-5,50$ & T Coccolithus formosus & 32.9 & 65.90 & 67.40 & 66.65 & 0.75 \\
\hline $9 \mathrm{H}-4,110$ & $10 \mathrm{H}-3,80$ & T Discoaster saipanensis & 34.4 & 76.00 & 83.70 & 79.85 & 3.85 \\
\hline $11 \mathrm{H}-5,70$ & $11 \mathrm{H}-6,70$ & T Chiasmolithus grandis & 37.1 & 96.10 & 97.60 & 96.85 & 0.75 \\
\hline $11 \mathrm{H}-\mathrm{CC}$ & $12 \mathrm{H}-2,100$ & B Dictyococcites bisectus & 38.0 & 98.52 & 101.40 & 99.96 & 1.44 \\
\hline $12 \mathrm{H}-2,100$ & $13 \mathrm{H}-1,140$ & T Chiasmolithus solitus & 40.4 & 101.40 & 109.80 & 105.60 & 4.20 \\
\hline $14 \mathrm{H}-5,40$ & $14 \mathrm{H}-6,35$ & T Nannotetrina & 42.3 & 124.30 & 125.74 & 125.02 & 0.72 \\
\hline $14 \mathrm{H}-\mathrm{CC}$ & $15 X-1,113$ & B Reticulofenestra umbilicus $>14 \mu \mathrm{m}$ & 42.5 & 126.28 & 127.03 & 126.66 & 0.38 \\
\hline $15 X-2,137$ & $15 X-3,66$ & T Nannotetrina fulgens & 43.4 & 128.77 & 129.56 & 129.17 & 0.39 \\
\hline $16 \mathrm{X}-2,39$ & $16 \mathrm{X}-\mathrm{CC}$ & B Nannotetrina fulgens & 46.8 & 137.39 & 138.20 & 137.80 & 0.41 \\
\hline $\begin{array}{l}\text { 320-U1332B- } \\
17 \mathrm{X}-\mathrm{CC}\end{array}$ & $\begin{array}{c}320-U 1332 \mathrm{~B}- \\
18 \mathrm{X}-2,48\end{array}$ & T Discoaster lodoensis & 48.4 & 135.06 & 145.88 & 140.47 & 5.41 \\
\hline
\end{tabular}

Note: $\mathrm{T}=$ top, $\mathrm{B}=$ bottom $\mathrm{X}=$ abundance crossover, $\mathrm{T} \mathrm{c}=$ top common.

Table T4. Preservation and relative abundance of radiolarians, Hole U1332A. This table is available in an oversized format. 


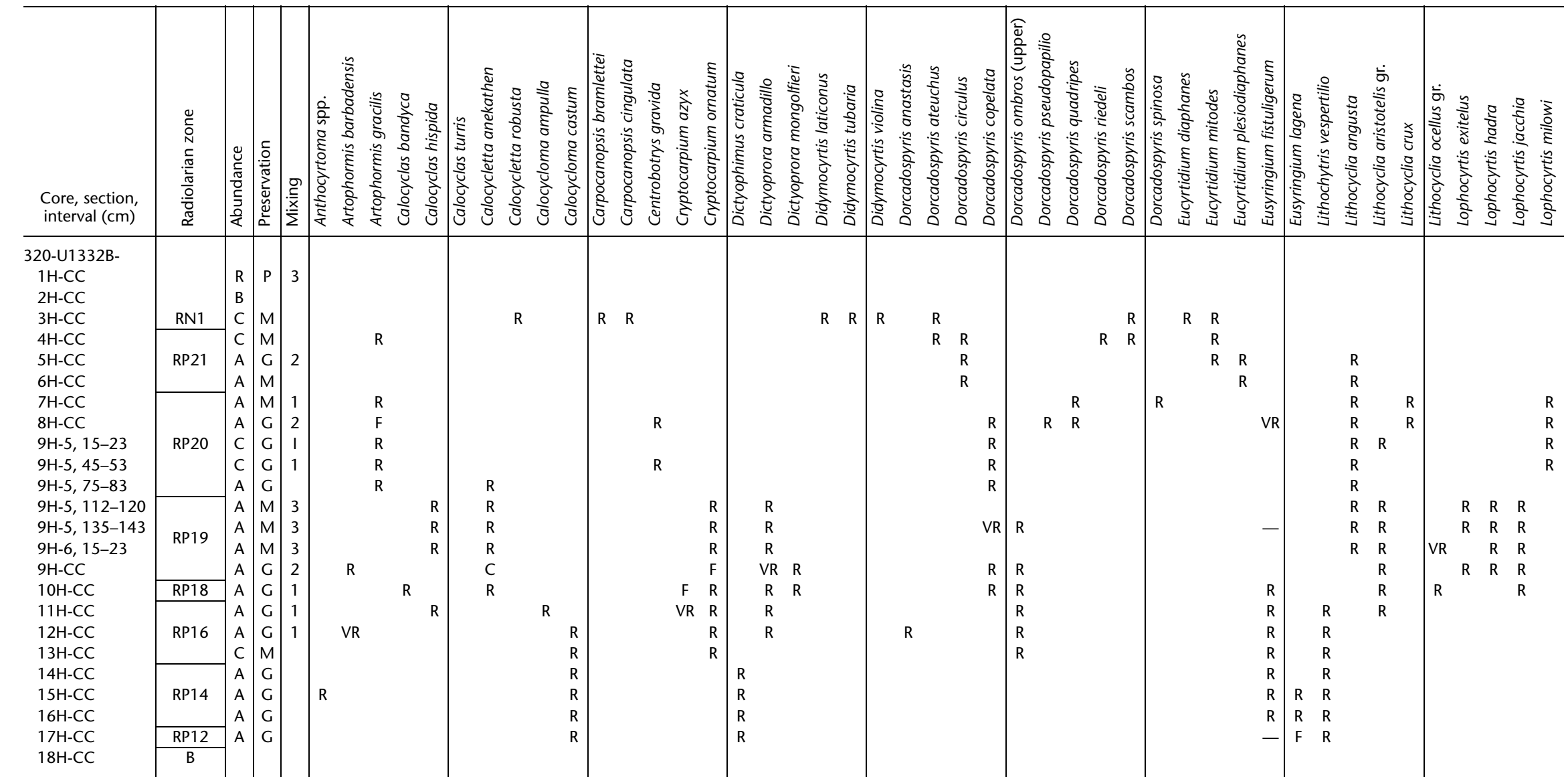

Notes: Abundance: $\mathrm{A}=$ abundant, $\mathrm{C}=$ common, $\mathrm{F}=$ frequent, $\mathrm{R}=$ rare, $\mathrm{VR}=$ very rare, $\mathrm{B}=$ barren,$-=$ undetermined. Preservation: $\mathrm{G}=\mathrm{good}, \mathrm{M}=$ moderate, $\mathrm{P}=$ poor. Mixing: blank $=$ no mixing of older specimens detected, $1=1-3$ reworked specimens detected, $2=3-10$ reworked specimens detected, $3=>10$ reworked specimens detected. 

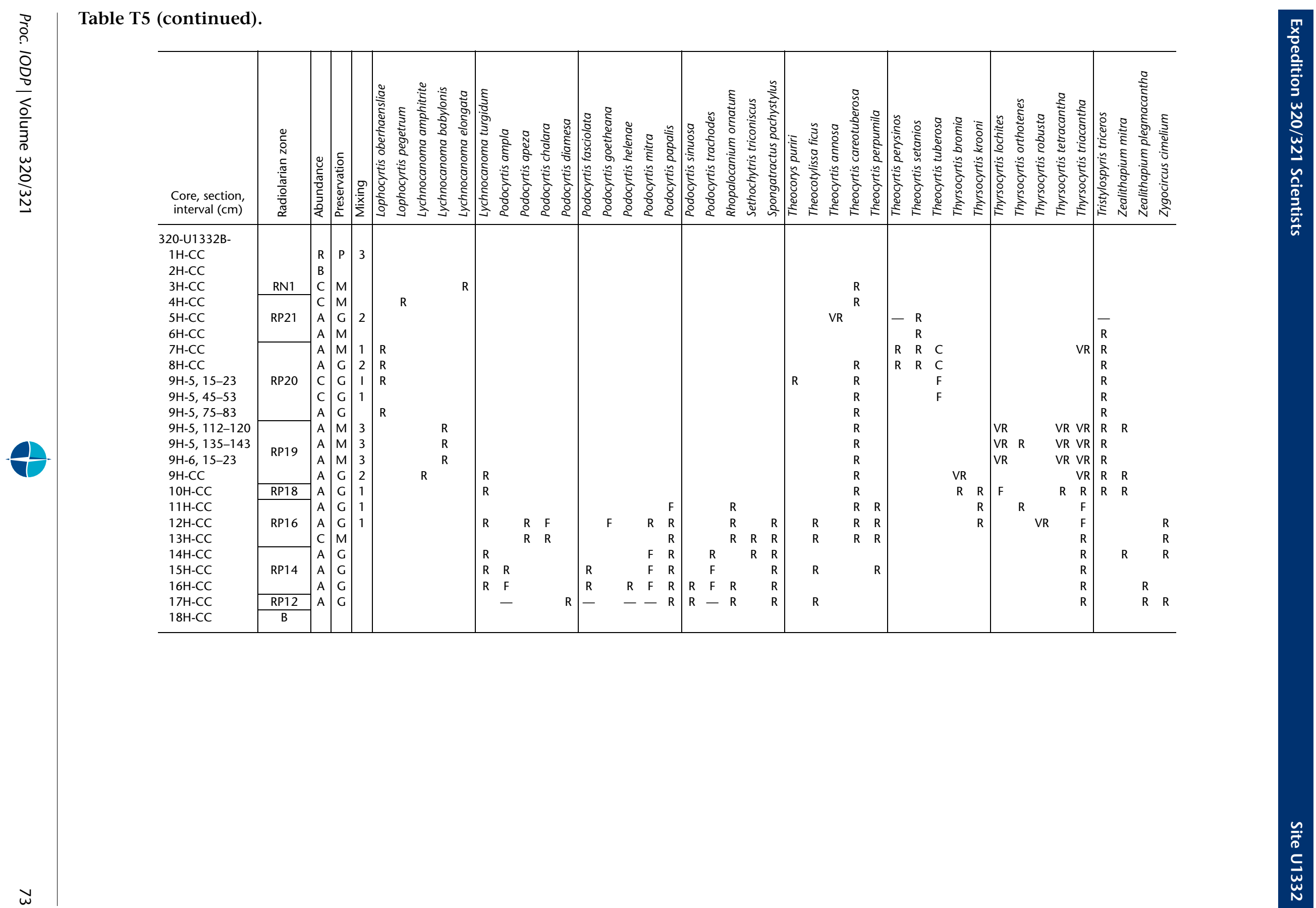


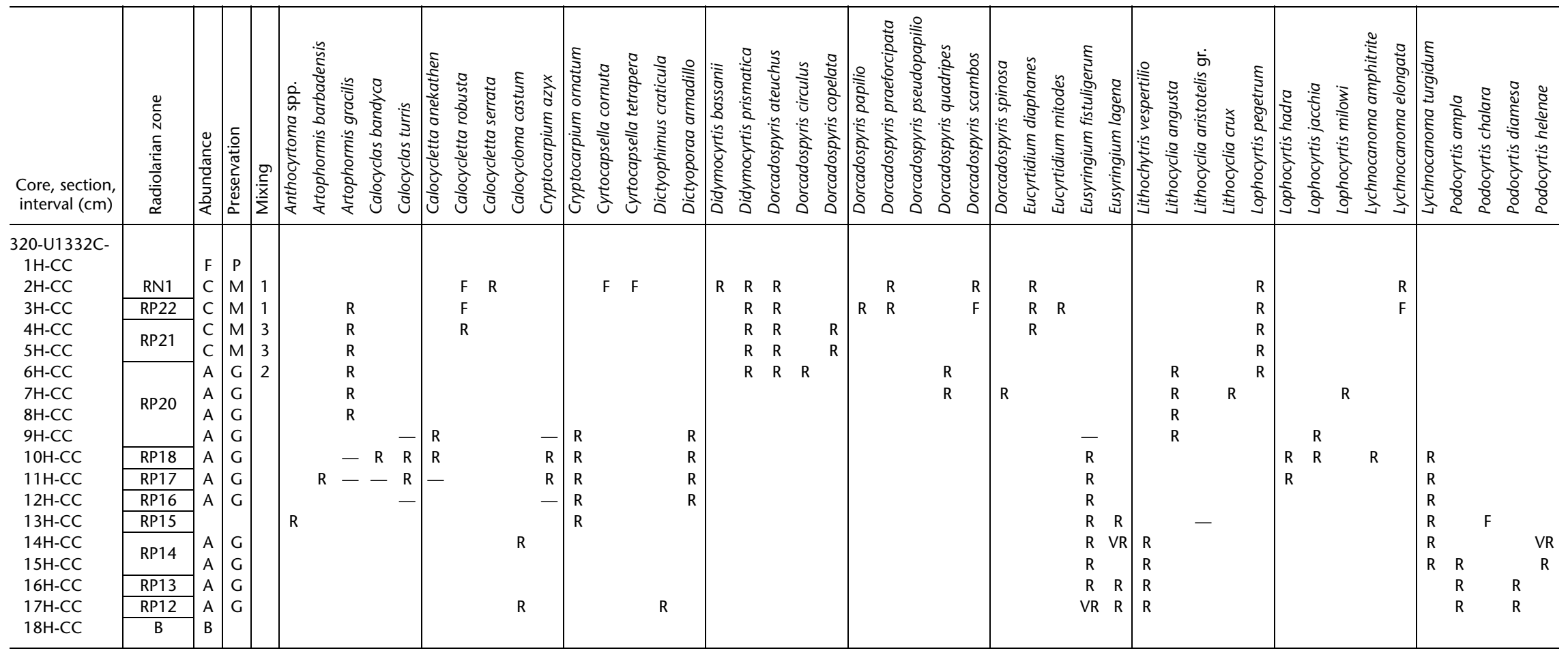

Notes: Abundance: $\mathrm{A}=$ abundant $\mathrm{C}=$ common, $\mathrm{F}=$ frequent $\mathrm{B}=$ barren, $\mathrm{R}=$ rare, $\mathrm{VR}=$ very rare,$-=$ undetermined. Preservation: $\mathrm{G}=\mathrm{good}, \mathrm{M}=$ moderate, $\mathrm{P}=$ poor. Mixing: blank $=$ no mixing of older specimens detected, $1=1-3$ reworked specimens detected, $2=3-10$ reworked specimens detected, $3=>10$ reworked specimens detected. 


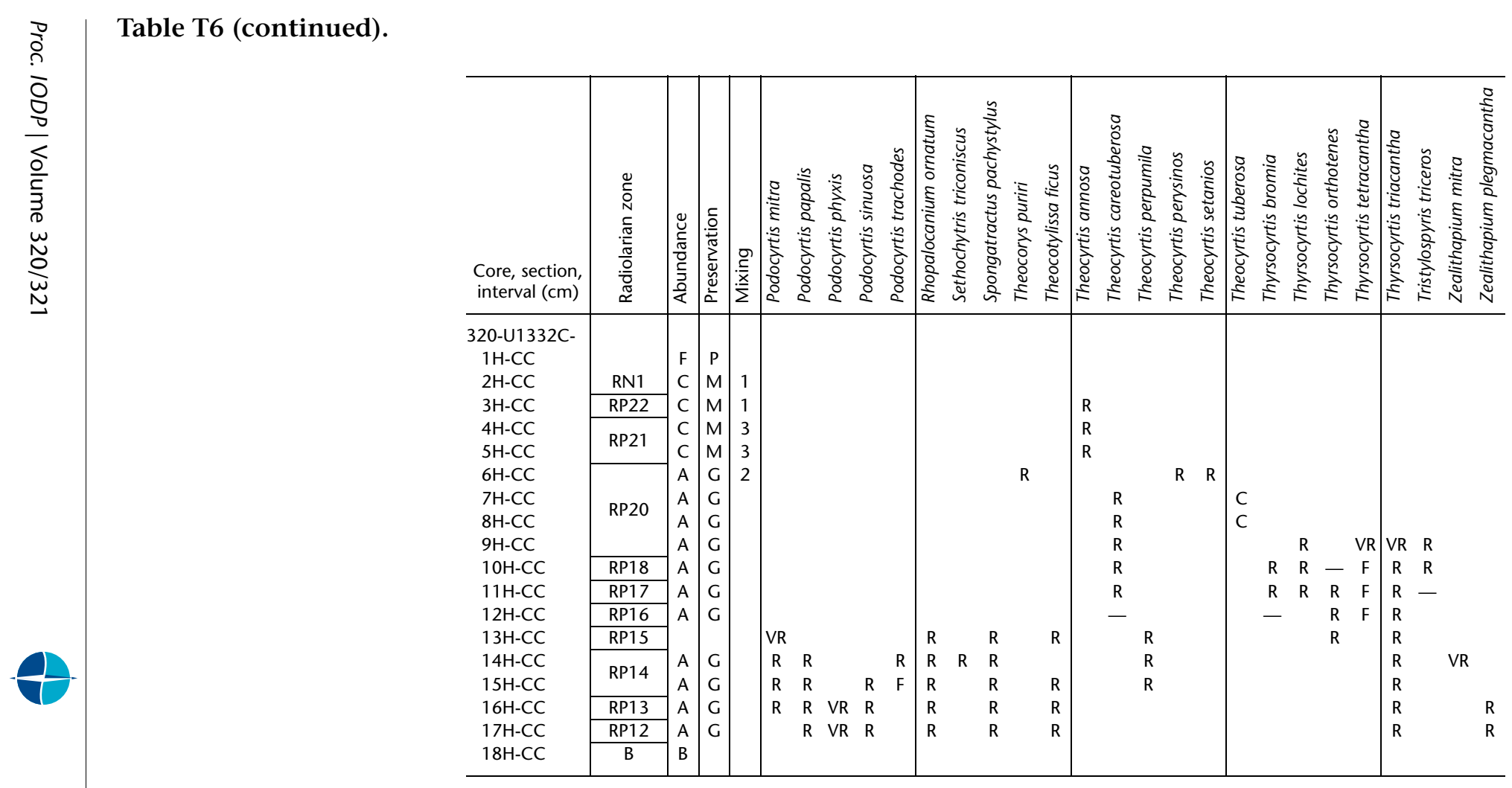


Table T7. Radiolarian datums, Site U1332. (See table notes.) (Continued on next page.)

\begin{tabular}{|c|c|c|c|c|c|c|c|c|c|}
\hline \multirow[b]{2}{*}{ Geologic age } & \multirow[b]{2}{*}{ Zone } & \multirow[b]{2}{*}{ Marker species } & \multirow{2}{*}{$\begin{array}{l}\text { Age } \\
(\mathrm{Ma})\end{array}$} & \multicolumn{2}{|c|}{ Core, section, interval $(\mathrm{cm})$} & \multicolumn{4}{|c|}{ Depth CSF $(m)$} \\
\hline & & & & Top & Bottom & Top & Bottom & Midpoint & \pm \\
\hline \multirow{3}{*}{ lower Miocene } & RN1 & & & 320-U1332A- & 320-U1332A- & & & & \\
\hline & & B C. cornuta & 22.26 & $3 \mathrm{H}-2,93-95$ & $3 \mathrm{H}-4,93-95$ & 15.87 & 18.83 & 17.35 & 1.48 \\
\hline & & B C. tetrapera & 22.35 & $3 \mathrm{H}-4,93-95$ & $3 \mathrm{H}-\mathrm{CC}$ & 18.83 & 23.52 & 21.18 & 2.35 \\
\hline \multirow{24}{*}{ upper Oligocene } & \multirow{9}{*}{ RP22 } & T A. gracilis & 22.62 & $3 \mathrm{H}-4,93-95$ & $3 \mathrm{H}-\mathrm{CC}$ & 18.83 & 23.52 & 21.18 & 2.35 \\
\hline & & B D. bassanii & 22.93 & $3 \mathrm{H}-4,93-95$ & $3 \mathrm{H}-\mathrm{CC}$ & 18.83 & 23.52 & 21.18 & 2.35 \\
\hline & & B E. diaphanes & 22.95 & $3 \mathrm{H}-4,93-95$ & $3 \mathrm{H}-\mathrm{CC}$ & 18.83 & 23.52 & 21.18 & 2.35 \\
\hline & & T D. cyclacantha & 22.98 & $3 \mathrm{H}-4,93-95$ & $3 \mathrm{H}-\mathrm{CC}$ & 18.83 & 23.52 & 21.18 & 2.35 \\
\hline & & $\mathrm{T} D$. riedeli & 23.01 & $3 \mathrm{H}-4,93-95$ & $3 \mathrm{H}-\mathrm{CC}$ & 18.83 & 23.52 & 21.18 & 2.35 \\
\hline & & B D. cyclacantha & 23.29 & $3 \mathrm{H}-\mathrm{CC}$ & $4 \mathrm{H}-2,105-107$ & 23.52 & 25.50 & 24.51 & 0.99 \\
\hline & & L L. longicornuta & 24.12 & $4 \mathrm{H}-2,105-107$ & $4 \mathrm{H}-4,105-107$ & 25.50 & 28.45 & 26.98 & 1.47 \\
\hline & & L A. octopylus & 24.38 & - & - & & & & \\
\hline & & L L. apodora & 24.5 & - & - & & & & \\
\hline & \multirow{15}{*}{ RP21 } & B L. elongata & 25.05 & $4 \mathrm{H}-4,105-107$ & $4 \mathrm{H}-\mathrm{CC}$ & 28.45 & 32.96 & 30.71 & 2.26 \\
\hline & & B A. octopylus & 25.09 & - & - & & & & \\
\hline & & B D. praeforcipata & 25.27 & $4 \mathrm{H}-4,105-107$ & $4 \mathrm{H}-\mathrm{CC}$ & 28.45 & 32.96 & 30.71 & 2.26 \\
\hline & & B C. robusta & 25.27 & $4 \mathrm{H}-4,105-107$ & $4 \mathrm{H}-\mathrm{CC}$ & 28.45 & 32.96 & 30.71 & 2.26 \\
\hline & & B D. tubaria & 25.27 & $4 \mathrm{H}-4,105-107$ & $4 \mathrm{H}-\mathrm{CC}$ & 28.45 & 32.96 & 30.71 & 2.26 \\
\hline & & B L. longicornuta & 25.29 & $4 \mathrm{H}-4,105-107$ & $4 \mathrm{H}-\mathrm{CC}$ & 28.45 & 32.96 & 30.71 & 2.26 \\
\hline & & B D. scambos & 25.33 & $4 \mathrm{H}-4,105-107$ & $4 \mathrm{H}-\mathrm{CC}$ & 28.45 & 32.96 & 30.71 & 2.26 \\
\hline & & B L. apodora & 25.55 & - & - & & & & \\
\hline & & T D. circulus & 26.17 & $4 \mathrm{H}-4,105-107$ & $4 \mathrm{H}-\mathrm{CC}$ & 28.45 & 32.96 & 30.71 & 2.26 \\
\hline & & B D. riedeli & 26.2 & & & & & & \\
\hline & & T E. plesiodiaphanes & 26.4 & $4 \mathrm{H}-\mathrm{CC}$ & $5 \mathrm{H}-2,110-112$ & 32.96 & 35.04 & 34.00 & 1.04 \\
\hline & & T L. angusta & 27.68 & $5 \mathrm{H}-2,110-112$ & $5 \mathrm{H}-4,105-107$ & 35.04 & 37.94 & 36.49 & 1.45 \\
\hline & & T T. setanios & 28.21 & $5 \mathrm{H}-4,105-107$ & $5 \mathrm{H}-\mathrm{CC}$ & 37.94 & 42.48 & 40.21 & 2.27 \\
\hline & & B T. annosa & 28.33 & $6 \mathrm{H}-2,105-107$ & $6 \mathrm{H}-4,105-107$ & 44.46 & 47.46 & 45.96 & 1.50 \\
\hline & & T. triceros $>D$. ateuchus & 28.60 & $6 \mathrm{H}-2,105-107$ & $6 \mathrm{H}-4,105-107$ & 44.46 & 47.46 & 45.96 & 1.50 \\
\hline \multirow{19}{*}{ lower Oligocene } & & B D. ateuchus & 29.50 & $6 \mathrm{H}-2,105-107$ & $6 \mathrm{H}-4,105-107$ & 44.46 & 47.46 & 45.96 & 1.50 \\
\hline & & B E. mitodes & 29.41 & $6 \mathrm{H}-4,105-107$ & $6 \mathrm{H}-\mathrm{CC}$ & 47.46 & 51.98 & 49.72 & 2.26 \\
\hline & & B D. circulus & 29.96 & $6 \mathrm{H}-4,105-107$ & $6 \mathrm{H}-\mathrm{CC}$ & 47.46 & 51.98 & 49.72 & 2.26 \\
\hline & & T T. tuberosa & 30.13 & $6 \mathrm{H}-\mathrm{CC}$ & 7H-3, 100-102 & 51.98 & 55.40 & 53.69 & 1.71 \\
\hline & & T L. crux & 30.13 & $6 \mathrm{H}-\mathrm{CC}$ & 7H-3, 100-102 & 51.98 & 55.40 & 53.69 & 1.71 \\
\hline & & B E. plesiodiaphanes & 30.37 & $6 \mathrm{H}-\mathrm{CC}$ & 7H-3, 100-102 & 51.98 & 55.40 & 53.69 & 1.71 \\
\hline & & T L. oberhaensliae & 30.74 & 7H-3, 100-102 & 7H-5, 100-102 & 55.40 & 58.41 & 56.91 & 1.50 \\
\hline & & B D. spinosa & 30.84 & 7H-5, 100-102 & $7 \mathrm{H}-\mathrm{CC}$ & 58.41 & 61.50 & 59.96 & 1.55 \\
\hline & & T D. pseudopaplilio & 30.84 & 7H-CC & $8 \mathrm{H}-2,105-107$ & 61.50 & 63.45 & 62.48 & 0.98 \\
\hline & & T C. gravida & 30.89 & $\mathrm{7H}-\mathrm{CC}$ & $8 \mathrm{H}-2,105-107$ & 61.50 & 63.45 & 62.48 & 0.98 \\
\hline & $R P \angle O$ & B L. crux & 31.00 & $8 \mathrm{H}-4,105-107$ & $8 \mathrm{H}-\mathrm{CC}$ & 66.45 & 71.01 & 68.73 & 2.28 \\
\hline & & B T. tuberosa & 31.00 & $8 \mathrm{H}-4,105-107$ & $8 \mathrm{H}-\mathrm{CC}$ & 66.45 & 71.01 & 68.73 & 2.28 \\
\hline & & B D. pseudopaplilio & 31.00 & $9 \mathrm{H}-1,92-98$ & $9 \mathrm{H}-3,92-98$ & 71.35 & 74.38 & 72.87 & 1.52 \\
\hline & & B C. gravida & 31.01 & $8 \mathrm{H}-4,105-107$ & $8 \mathrm{H}-\mathrm{CC}$ & 66.45 & 71.01 & 68.73 & 2.28 \\
\hline & & T T. triacantha & 33.34 & $\begin{array}{r}9 \mathrm{H}-3,92-98 \\
(8 \mathrm{H}-4,105)\end{array}$ & $\begin{array}{c}9 \mathrm{H}-5,92-98 \\
(8 \mathrm{H}-\mathrm{CC})\end{array}$ & 74.37 & 77.34 & 75.86 & 1.49 \\
\hline & & T L. aristotelis gr. & 33.51 & $9 \mathrm{H}-3,92-98$ & $9 \mathrm{H}-5,92-98$ & 74.37 & 77.34 & 75.86 & 1.49 \\
\hline & & T C. hispida & 33.62 & $9 \mathrm{H}-3,92-98$ & $9 \mathrm{H}-5,92-98$ & 74.37 & 77.34 & 75.86 & 1.49 \\
\hline & & T C. ornatum & 33.62 & $9 \mathrm{H}-3,92-98$ & $9 \mathrm{H}-5,92-98$ & 74.37 & 77.34 & 75.86 & 1.49 \\
\hline & & T L. babylonis & 33.75 & $9 \mathrm{H}-3,92-98$ & $9 \mathrm{H}-5,92-98$ & 74.37 & 77.34 & 75.86 & 1.49 \\
\hline & & L. aristotelis $>$ L. angusta & 33.82 & $9 \mathrm{H}-5,92-98$ & $9 \mathrm{H}-\mathrm{CC}$ & 77.34 & 81.68 & 79.51 & 2.17 \\
\hline & & T D. copetata & 33.84 & $9 \mathrm{H}-5,92-98$ & 9H-CC & 77.34 & 81.68 & 79.51 & 2.17 \\
\hline & RP19 & B L. angusta & 34.13 & $9 \mathrm{H}-\mathrm{CC}$ & $10 \mathrm{H}-2,94-96$ & 81.68 & 82.34 & 82.01 & 0.33 \\
\hline upper Eocene & & T C. bandyca & 34.62 & 9H-CC & $10 \mathrm{H}-2,94-96$ & 81.68 & 82.34 & 82.01 & 0.33 \\
\hline & & T T. tetracantha & 35.30 & $9 \mathrm{H}-\mathrm{CC}$ & $10 \mathrm{H}-2,94-96$ & 81.68 & 82.34 & 82.01 & 0.33 \\
\hline & RP18 & B L. hadra & 35.34 & $10 \mathrm{H}-2,94-96$ & $10 \mathrm{H}-4,94-96$ & 82.34 & 85.34 & 83.84 & 1.50 \\
\hline & & B C. bandyca & 36.74 & $10 \mathrm{H}-4,94-96$ & $10 \mathrm{H}-\mathrm{CC}$ & 85.34 & 89.90 & 87.62 & 2.28 \\
\hline & RP17 & B L. jacchia & 37.06 & $10 \mathrm{H}-\mathrm{CC}$ & $11 \mathrm{H}-2,105-107$ & 89.90 & 91.94 & 90.92 & 1.02 \\
\hline & & B C. $a z y x$ & 37.52 & $11 \mathrm{H}-2,105-107$ & $11 \mathrm{H}-4,105-107$ & 91.94 & 94.94 & 93.44 & 1.50 \\
\hline & & T Anthocyrtoma spp. & 37.92 & $11 \mathrm{H}-4,105-107$ & $12 \mathrm{H}-\mathrm{CC}$ & 94.94 & 98.53 & 96.74 & 1.80 \\
\hline & & B T. bromia & 38.07 & $11 \mathrm{H}-4,105-107$ & $12 \mathrm{H}-\mathrm{CC}$ & 94.94 & 98.53 & 96.74 & 1.80 \\
\hline & & B T. tetracantha & 38.12 & $11 \mathrm{H}-4,105-107$ & $12 \mathrm{H}-\mathrm{CC}$ & 94.94 & 98.53 & 96.74 & 1.80 \\
\hline & RP16 & $\mathrm{T}$ D. anastasis & 38.45 & $12 \mathrm{H}-2,105-107$ & $12 \mathrm{H}-4,105-107$ & 101.46 & 104.46 & 102.96 & 1.50 \\
\hline middle tocene & & B C. turris & 38.67 & $11 \mathrm{H}-\mathrm{CC}$ & $12 \mathrm{H}-2,105-107$ & 98.53 & 101.46 & 100.00 & 1.46 \\
\hline & & B L. aristotelis gr. & 39.73 & $12 \mathrm{H}-2,105-107$ & $12 \mathrm{H}-4,105-107$ & 101.46 & 104.46 & 102.96 & 1.50 \\
\hline & & B D. anastasis & 39.98 & $12 \mathrm{H}-4,105-107$ & $13 \mathrm{H}-\mathrm{CC}$ & 104.46 & 108.46 & 106.46 & 2.00 \\
\hline & & B P. goetheana & 40.16 & $12 \mathrm{H}-4,105-107$ & $13 \mathrm{H}-\mathrm{CC}$ & 104.46 & 108.46 & 106.46 & 2.00 \\
\hline & RP15 & T L. biaurita & 40.36 & $12 \mathrm{H}-4,105-107$ & $13 \mathrm{H}-\mathrm{CC}$ & 104.46 & 108.46 & 106.46 & 2.00 \\
\hline & & P. mitra $>$ P. chalara & 40.70 & $13 \mathrm{H}-\mathrm{CC}$ & $14 \mathrm{H}-2,104-106$ & 118.39 & 120.44 & 119.42 & 1.03 \\
\hline
\end{tabular}


Table T7 (continued).

\begin{tabular}{|c|c|c|c|c|c|c|c|c|c|}
\hline \multirow[b]{2}{*}{ Geologic age } & \multirow[b]{2}{*}{ Zone } & \multirow[b]{2}{*}{ Marker species } & \multirow{2}{*}{$\begin{array}{l}\text { Age } \\
\text { (Ma) }\end{array}$} & \multicolumn{2}{|c|}{ Core, section, interval $(\mathrm{cm})$} & \multicolumn{4}{|c|}{ Depth CSF (m) } \\
\hline & & & & Top & Bottom & Top & Bottom & Midpoint & \pm \\
\hline \multirow{18}{*}{ middle Eocene } & \multirow{9}{*}{ RP14 } & T P. trachodes & 41.23 & $13 \mathrm{H}-\mathrm{CC}$ & $14 \mathrm{H}-2,104-106$ & 118.39 & 120.44 & 119.42 & 1.03 \\
\hline & & B P. chalara & 41.54 & $14 \mathrm{H}-2,104-106$ & $14 \mathrm{H}-4,104-106$ & 120.44 & 123.45 & 121.95 & 1.51 \\
\hline & & B C. ornatum & 42.10 & $14 \mathrm{H}-4,104-106$ & $14 \mathrm{H}-\mathrm{CC}$ & 123.45 & 126.29 & 124.87 & 1.42 \\
\hline & & B S. triconiscus & 42.40 & $14 \mathrm{H}-\mathrm{CC}$ & $15 X-3,42-44$ & 126.29 & 129.36 & 127.83 & 1.53 \\
\hline & & T E. lagena & 42.69 & $14 \mathrm{H}-\mathrm{CC}$ & $15 X-3,42-44$ & 126.29 & 129.36 & 127.83 & 1.53 \\
\hline & & B T. perpumila & 42.97 & $14 \mathrm{H}-\mathrm{CC}$ & $15 X-3,42-44$ & 126.29 & 129.36 & 127.83 & 1.53 \\
\hline & & T P. helenae & 43.05 & $14 \mathrm{H}-2,104-106$ & $14 \mathrm{H}-4,104-106$ & 120.44 & 123.45 & 121.95 & 1.51 \\
\hline & & B P. trachodes & 43.22 & $16 X-1,41-49$ & $16 X-1,112-120$ & 135.94 & 136.66 & 136.30 & 0.36 \\
\hline & & B Z. cimelium & 43.35 & $15 X-5,40-42$ & $15 X-C C$ & 132.30 & 132.93 & 132.62 & 0.31 \\
\hline & & P. sinuosa $>$ P. mitra & 43.84 & $16 X-1,112-120$ & $16 X-2,37-44$ & 136.66 & 137.36 & 137.01 & 0.35 \\
\hline & \multirow{8}{*}{ RP13 } & & & 320-U1332C- & 320-U133C- & & & & \\
\hline & & B P. helenae & 44.14 & $15 X-C C$ & $16 \mathrm{X}-\mathrm{CC}$ & 132.93 & 138.20 & 135.57 & 2.63 \\
\hline & & T P. phyxis & 44.44 & $15 X-C C$ & $16 \mathrm{X}-\mathrm{CC}$ & 132.93 & 138.20 & 135.57 & 2.63 \\
\hline & & T P. diamesa & 44.44 & $15 X-C C$ & $16 \mathrm{X}-\mathrm{CC}$ & 132.93 & 138.20 & 135.57 & 2.63 \\
\hline & & T S. balbis & 44.77 & $16 \mathrm{X}-\mathrm{CC}$ & $17 \mathrm{X}-\mathrm{CC}$ & 138.20 & 146.90 & 142.55 & 4.35 \\
\hline & & B P. mitra & 44.77 & $16 \mathrm{X}-\mathrm{CC}$ & $17 \mathrm{X}-\mathrm{CC}$ & 138.20 & 146.90 & 142.55 & 4.35 \\
\hline & & B P. ampla & 44.77 & $16 \mathrm{X}-\mathrm{CC}$ & $17 \mathrm{X}-\mathrm{CC}$ & 138.20 & 146.90 & 142.55 & 4.35 \\
\hline & & P. phyxis > P. ampla & 44.77 & $16 \mathrm{X}-\mathrm{CC}$ & $17 \mathrm{X}-\mathrm{CC}$ & 138.20 & 146.90 & 142.55 & 4.35 \\
\hline
\end{tabular}

Notes: $\mathrm{B}=$ bottom, $\mathrm{T}=$ top, $\mathrm{L}=$ last. $-=$ not encountered.

Table T8. Planktonic foraminifer datums, Site U1332. (See table note.)

\begin{tabular}{|c|c|c|c|c|c|c|c|}
\hline \multicolumn{2}{|c|}{ Core, section, interval $(\mathrm{cm})$} & \multirow[b]{2}{*}{ Marker species } & \multirow{2}{*}{$\begin{array}{l}\text { Age } \\
\text { (Ma) }\end{array}$} & \multicolumn{4}{|c|}{ Depth CSF $(m)$} \\
\hline Top & Bottom & & & Top & Bottom & Midpoint & \pm \\
\hline 320-U1331A- & 320-U1331A- & & & & & & \\
\hline $4 \mathrm{H}-\mathrm{CC}, 26-31$ & $5 \mathrm{H}-2,100-101$ & T Paragloborotalia opima & 26.9 & 32.95 & 34.90 & 33.93 & 0.97 \\
\hline $6 \mathrm{H}-\mathrm{CC}, 27-32$ & $7 \mathrm{H}-4,38-40$ & T Subbotina angiporoides & 29.8 & 51.97 & 56.28 & 54.13 & 4.76 \\
\hline $6 \mathrm{H}-\mathrm{CC}, 27-32$ & 7H-2-38-40 & B Paragloborotalia opima & 30.8 & 51.97 & 53.28 & 52.63 & 0.66 \\
\hline 320-U1331B- & 320-U1331B- & & & & & & \\
\hline $4 \mathrm{H}-\mathrm{CC}, 23-28$ & $5 \mathrm{H}-\mathrm{CC}, 21-26$ & T Paragloborotalia opima & 26.9 & 29.61 & 37.63 & 33.62 & 4.01 \\
\hline $5 \mathrm{H}-\mathrm{CC}, 21-26$ & $6 \mathrm{H}-\mathrm{CC}, 9-14$ & T Subbotina angiporoides & 29.8 & 37.63 & 48.50 & 43.07 & 5.44 \\
\hline 7H-CC, 23-26 & $8 \mathrm{H}-\mathrm{CC}, 33-36$ & B Paragloborotalia opima & 30.8 & 58.07 & 67.47 & 62.77 & 4.70 \\
\hline 320-U1331C- & 320-U1331C- & & & & & & \\
\hline $3 \mathrm{H}-\mathrm{CC}, 18-21$ & $4 \mathrm{H}-\mathrm{CC}, 28-31$ & T Paragloborotalia opima & 26.9 & 26.93 & 36.52 & 31.73 & 4.80 \\
\hline $4 \mathrm{H}-\mathrm{CC}, 28-31$ & $5 \mathrm{H}-\mathrm{CC}, 22-25$ & B Globigerina angulisuturalis & 29.2 & 36.52 & 45.76 & 41.14 & 4.62 \\
\hline $5 \mathrm{H}-\mathrm{CC}, 22-25$ & $6 \mathrm{H}-\mathrm{CC}, 22-25$ & T Subbotina angiporoides & 29.8 & 45.76 & 53.04 & 49.40 & 3.64 \\
\hline $5 \mathrm{H}-\mathrm{CC}, 22-25$ & $6 \mathrm{H}-\mathrm{CC}, 22-25$ & B Paragloborotalia opima & 30.8 & 45.76 & 53.04 & 49.40 & 3.64 \\
\hline
\end{tabular}

Note: $\mathrm{T}=$ top, $\mathrm{B}=$ bottom. 
Table T9. Distribution of planktonic foraminifers, Site U1332. (See table notes.) (Continued on next page.)

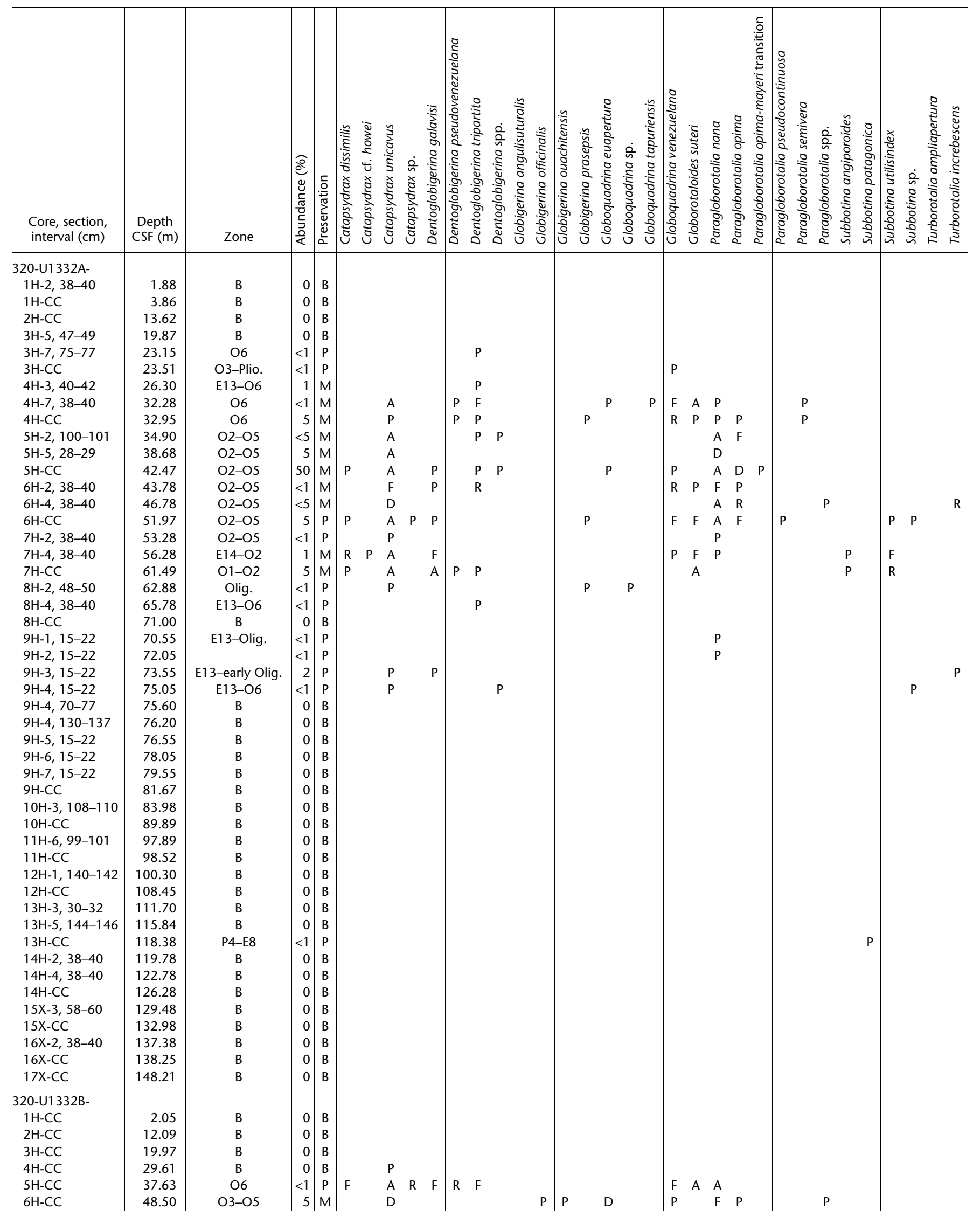


Table T9 (continued).

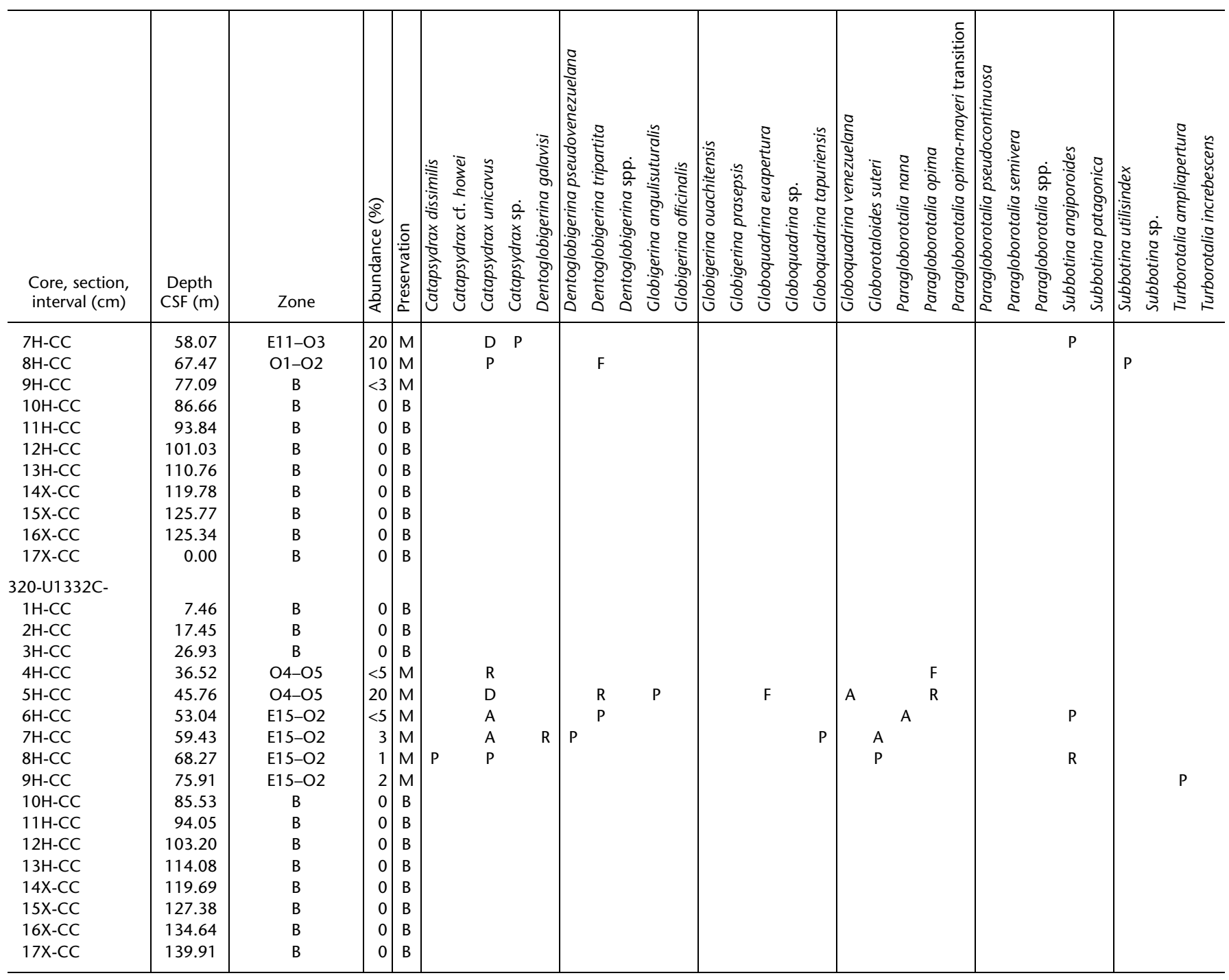

Notes: Abundance: $\mathrm{D}=$ dominant, $\mathrm{A}=$ abundant, $\mathrm{F}=$ few, $\mathrm{P}=$ present, $\mathrm{R}=$ rare. Abundance estimated from total number of particles in the $>250$ $\mu \mathrm{m}$ size fraction. Preservation: $\mathrm{M}=$ moderate, $\mathrm{P}=$ poor, $\mathrm{B}=$ barren. 
Table T10. Distribution of benthic foraminifers, Site U1332. (See table notes.) (Continued on next two pages.)

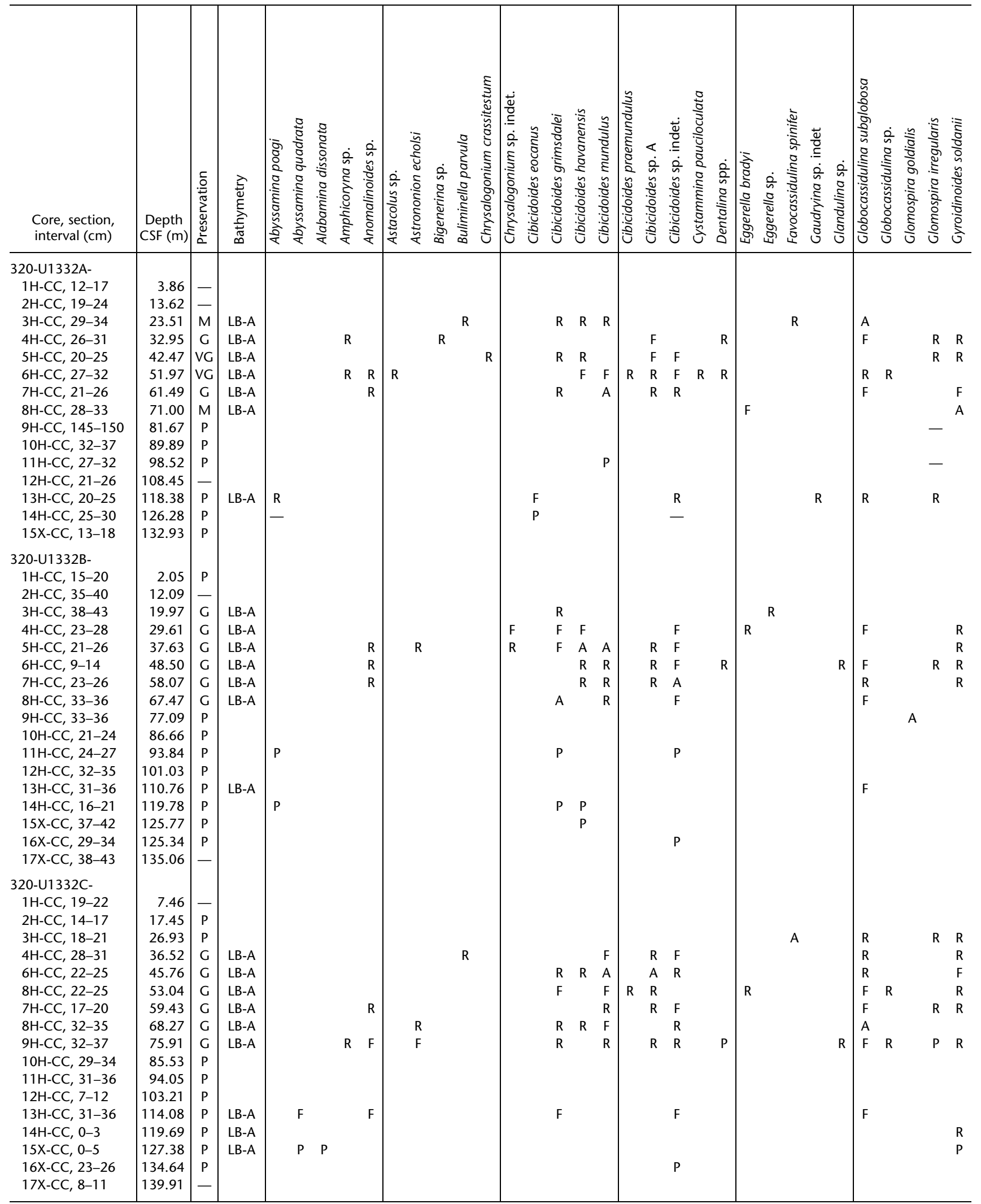

Notes: $-=$ presence of specimens found during other observations (other size fractions or planktonic foraminifer analysis). Preservation: $V G=$ very good, $G=$ good, $M=$ moderate,$P=$ poor. $L B=$ lower bathyal zone, $A=$ abyssal zone. Abundance: $D=$ dominant,$A=$ abundant, $F=$ frequent, $\mathrm{R}=$ rare, $\mathrm{P}=$ present. 
Table T10 (continued). (Continued on next page.)

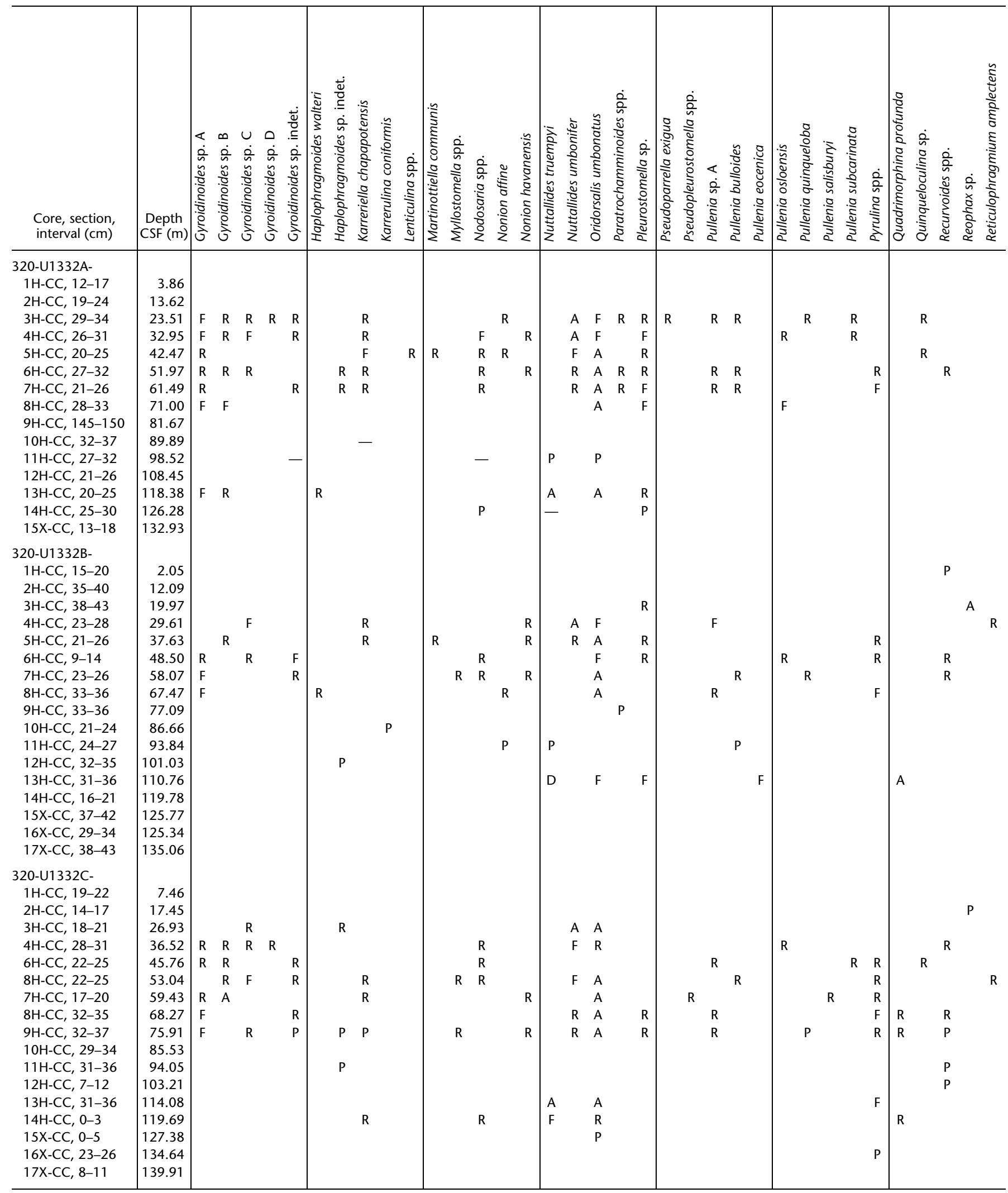


Table T10 (continued).

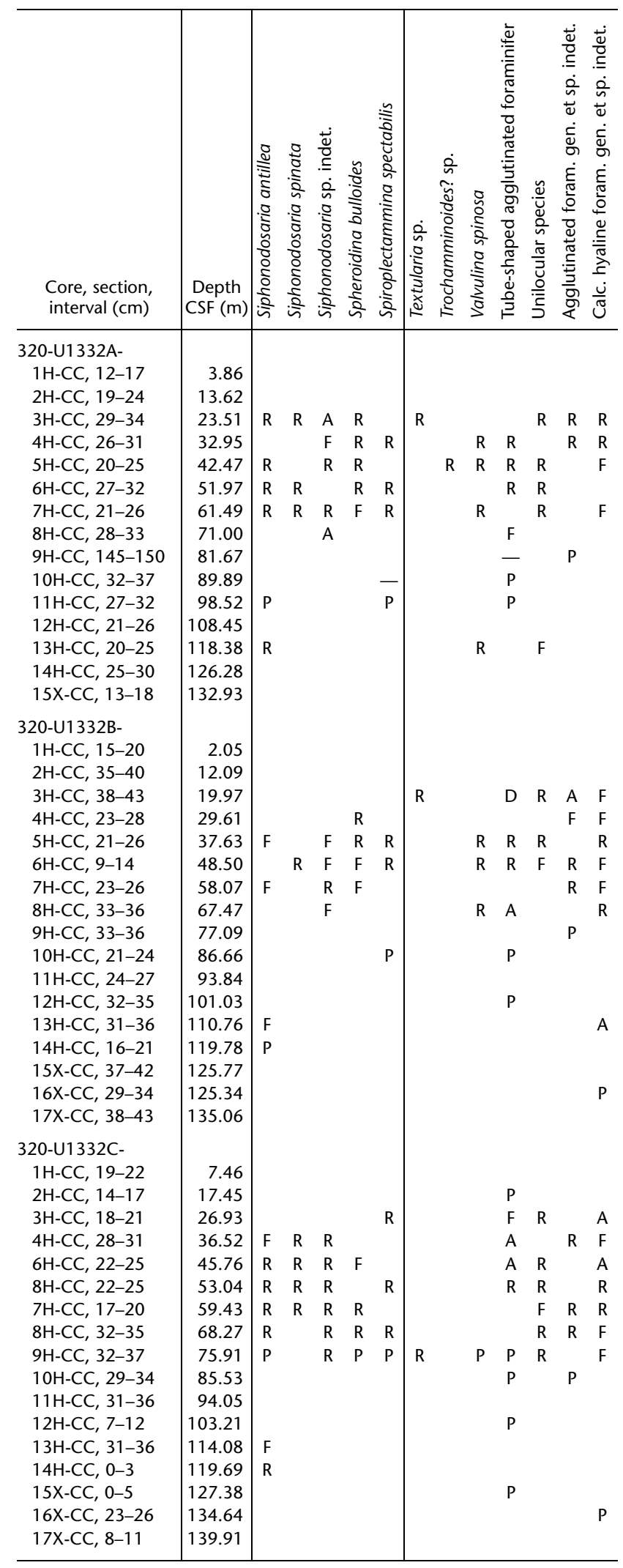


Table T11. Coring-disturbed intervals and gaps, Site U1332. (See table notes.)

\begin{tabular}{|c|c|c|c|}
\hline $\begin{array}{l}\text { Core, section, } \\
\text { interval }(\mathrm{cm})\end{array}$ & $\begin{array}{c}\text { Type of } \\
\text { disturbance }\end{array}$ & $\begin{array}{l}\text { Core, section, } \\
\text { interval }(\mathrm{cm})\end{array}$ & $\begin{array}{c}\text { Type of } \\
\text { disturbance }\end{array}$ \\
\hline \multicolumn{2}{|l|}{ 320-U1332A- } & $3 \mathrm{H}-2,0-45$ & Top of core \\
\hline $1 \mathrm{H}-1,0-100$ & Top of core & $4 \mathrm{H}-1,0-148$ & Top of core \\
\hline $1 \mathrm{H}-2,145-150$ & Interstitial water & $4 \mathrm{H}-3,140-150$ & Mills sample \\
\hline $2 \mathrm{H}-1,0-5$ & Top of core & $5 \mathrm{H}-1,0-118$ & Top of core \\
\hline $2 \mathrm{H}-2,145-150$ & Interstitial water & $6 \mathrm{H}-1,0-150$ & Top of core \\
\hline $2 \mathrm{H}-5,145-150$ & Interstitial water & $6 \mathrm{H}-2,0-54$ & Top of core \\
\hline $3 \mathrm{H}-1,0-75$ & Top of core & $6 \mathrm{H}-6,84-150$ & Top of core \\
\hline $3 \mathrm{H}-2,145-150$ & Interstitial water & $7 \mathrm{H}-1,0-2$ & Top of core \\
\hline $3 \mathrm{H}-5,145-150$ & Interstitial water & $8 \mathrm{H}-1,0-150$ & Top of core \\
\hline $4 \mathrm{H}-1,0-8$ & Top of core & $8 \mathrm{H}-2,0-60$ & Top of core \\
\hline $4 \mathrm{H}-2,145-150$ & Interstitial water & $9 \mathrm{H}-1,0-24$ & Top of core \\
\hline $4 \mathrm{H}-5,145-150$ & Interstitial water & $10 \mathrm{H}-1,0-97$ & Top of core \\
\hline $5 \mathrm{H}-2,145-150$ & Interstitial water & $11 \mathrm{H}-1,0-150$ & Top of core \\
\hline $5 \mathrm{H}-5,145-150$ & Interstitial water & $11 \mathrm{H}-2,0-52$ & Top of core \\
\hline $6 \mathrm{H}-1,0-61$ & Top of core & $12 \mathrm{H}-1,0-86$ & Top of core \\
\hline $6 \mathrm{H}-3,145-150$ & Interstitial water & $13 \mathrm{H}-1,0-82$ & Top of core \\
\hline $6 \mathrm{H}-5,145-150$ & Interstitial water & $15 X-4,79-150$ & Slightly brecciated \\
\hline $7 \mathrm{H}-3,32-37$ & Paleontology & $15 X-5,0-150$ & Slightly brecciated \\
\hline $7 \mathrm{H}-4,138-150$ & Gamage sample & $15 X-6,0-150$ & Slightly brecciated \\
\hline $8 \mathrm{H}-1,0-150$ & Top of core & $16 \mathrm{X}-1,22-24$ & Slightly brecciated \\
\hline $8 \mathrm{H}-2,0-32$ & Very soft & $17 X-1,25-150$ & Brecciated \\
\hline $8 \mathrm{H}-2,145-150$ & Interstitial water & 320-U1332C- & \\
\hline $8 \mathrm{H}-7,145-150$ & Interstitial water & $1 \mathrm{H}-1,0-48$ & Top of core \\
\hline $9 \mathrm{H}-2,145-150$ & Interstitial water & $2 \mathrm{H}-1,0-130$ & Top of core \\
\hline $9 \mathrm{H}-4,0-8$ & Top of core & $3 \mathrm{H}-1,0-150$ & Top of core \\
\hline $10 \mathrm{H}-1,0-60$ & Top of core & $3 \mathrm{H}-2,62-65$ & Expansion \\
\hline $10 \mathrm{H}-2,145-150$ & Interstitial water & $3 \mathrm{H}-2,70-73$ & Expansion \\
\hline $10 \mathrm{H}-3,145-150$ & Interstitial water & $4 \mathrm{H}-1,0-15$ & Top of core \\
\hline $11 \mathrm{H}-1,0-137$ & Top of core & $5 \mathrm{H}-1,0-6$ & Top of core \\
\hline $11 \mathrm{H}-3,145-150$ & Interstitial water & $6 \mathrm{H}-1,0-150$ & Top of core \\
\hline $12 \mathrm{H}-1,0-118$ & Top of core & $6 \mathrm{H}-2,0-108$ & Top of core \\
\hline $12 \mathrm{H}-3,145-150$ & Interstitial water & $7 \mathrm{H}-1,0-20$ & Top of core \\
\hline $12 \mathrm{H}-4,0-10$ & Top of core & $8 \mathrm{H}-1,0-135$ & Top of core \\
\hline $12 \mathrm{H}-5,138-150$ & Gamage sample & $9 \mathrm{H}-1,0-35$ & Slightly disturbed \\
\hline $13 \mathrm{H}-3,145-150$ & Interstitial water & $10 \mathrm{H}-1,0-150$ & Core barrel dropped downhole (disturbed) \\
\hline $14 \mathrm{H}-1,0-143$ & Top of core & $10 \mathrm{H}-2,0-150$ & Core barrel dropped downhole (disturbed) \\
\hline $14 \mathrm{H}-3,145-150$ & Interstitial water & $10 \mathrm{H}-3,0-150$ & Core barrel dropped downhole (disturbed) \\
\hline $15 X-1,52-72$ & Disturbed & $10 \mathrm{H}-4,0-150$ & Core barrel dropped downhole (disturbed) \\
\hline $15 X-2,107-117$ & Disturbed & $10 \mathrm{H}-5,0-150$ & Core barrel dropped downhole (disturbed) \\
\hline $15 X-3,145-150$ & Interstitial water & $10 \mathrm{H}-6,0-150$ & Core barrel dropped downhole (disturbed) \\
\hline $16 \mathrm{X}-1,0-32$ & Top of core & $10 \mathrm{H}-7,0-74$ & Core barrel dropped downhole (disturbed) \\
\hline 320-U1332B- & & $11 \mathrm{H}-1,0-50$ & Top of core \\
\hline $2 \mathrm{H}-3,140-150$ & Mills sample & $13 \mathrm{H}-1,0-130$ & Top of core \\
\hline
\end{tabular}

Notes: When interval listed is $0-150 \mathrm{~cm}$, entire section is included even if true section length is $<150 \mathrm{~cm}$. Top of core $=$ myriad forms of voids, disturbance, and debris from uphole that affect top portion of most cores. For that reason, probably the top $20 \mathrm{~cm}$ or so of all cores should be avoided. Gamage sample $=$ whole-round sample taken for K. Gamage, Mills sample $=$ whole-round sample taken for H. Mills. 
Table T12. Paleomagnetic data from archive-half sections, Hole U1332A, at $0 \mathrm{mT}$ AF demagnetization. (See table notes.)

\begin{tabular}{|c|c|c|c|c|c|c|}
\hline $\begin{array}{l}\text { Core, } \\
\text { section }\end{array}$ & $\begin{array}{l}\text { Offset } \\
(\mathrm{m})\end{array}$ & $\begin{array}{l}\text { Depth CSF } \\
(\mathrm{m})\end{array}$ & $\begin{array}{c}\text { Declination } \\
\left({ }^{\circ}\right)\end{array}$ & $\begin{array}{c}\text { Inclination } \\
\left({ }^{\circ}\right)\end{array}$ & $\begin{array}{l}\text { Intensity } \\
(\mathrm{A} / \mathrm{m})\end{array}$ & $\begin{array}{c}\text { Time } \\
(s)\end{array}$ \\
\hline \multicolumn{7}{|c|}{ 320-U1332A- } \\
\hline $1 \mathrm{H}-1$ & 1.05 & 1.05 & 358.2 & 66.6 & $2.329 \mathrm{E}-02$ & 3320732162.73437 \\
\hline $1 \mathrm{H}-1$ & 1.10 & 1.10 & 354.3 & 67.2 & $2.620 \mathrm{E}-02$ & 3320732168.06250 \\
\hline $1 \mathrm{H}-1$ & 1.15 & 1.15 & 357.4 & 70.1 & $2.808 \mathrm{E}-02$ & 3320732173.39062 \\
\hline $1 \mathrm{H}-1$ & 1.20 & 1.20 & 355.6 & 77.8 & $2.750 \mathrm{E}-02$ & 3320732178.71875 \\
\hline $1 \mathrm{H}-1$ & 1.25 & 1.25 & 247.6 & 88.2 & $2.504 \mathrm{E}-02$ & 3320732184.04687 \\
\hline $1 \mathrm{H}-1$ & 1.30 & 1.30 & 185.6 & 78.5 & $2.381 \mathrm{E}-02$ & 3320732189.35937 \\
\hline $1 \mathrm{H}-1$ & 1.35 & 1.35 & 173.4 & 75.4 & $2.238 \mathrm{E}-02$ & 3320732194.68750 \\
\hline $1 \mathrm{H}-1$ & 1.40 & 1.40 & 178.4 & 75.9 & $2.175 E-02$ & 3320732200.01562 \\
\hline $1 \mathrm{H}-2$ & 0.10 & 1.60 & 194.5 & 82.9 & $2.325 \mathrm{E}-02$ & 3320733396.03125 \\
\hline $1 \mathrm{H}-2$ & 0.15 & 1.65 & 190.4 & 78.2 & $2.274 \mathrm{E}-02$ & 3320733401.35937 \\
\hline $1 \mathrm{H}-2$ & 0.20 & 1.70 & 174.4 & 73.7 & $2.055 \mathrm{E}-02$ & 3320733406.68750 \\
\hline $1 \mathrm{H}-2$ & 0.25 & 1.75 & 178.7 & 86.2 & $1.870 \mathrm{E}-02$ & 3320733412.00000 \\
\hline $1 \mathrm{H}-2$ & 0.30 & 1.80 & 356.1 & 75.5 & $2.293 \mathrm{E}-02$ & 3320733417.32812 \\
\hline $1 \mathrm{H}-2$ & 0.35 & 1.85 & 354.9 & 75.9 & $2.578 \mathrm{E}-02$ & 3320733422.65625 \\
\hline $1 \mathrm{H}-2$ & 0.40 & 1.90 & 345.9 & 73.7 & $2.748 \mathrm{E}-02$ & 3320733427.98437 \\
\hline $1 \mathrm{H}-2$ & 0.45 & 1.95 & 343.9 & 71.0 & $2.882 \mathrm{E}-02$ & 3320733433.31250 \\
\hline $1 \mathrm{H}-2$ & 0.50 & 2.00 & 346.5 & 79.7 & $2.854 \mathrm{E}-02$ & 3320733438.62500 \\
\hline $1 \mathrm{H}-2$ & 0.55 & 2.05 & 356.1 & 84.1 & $3.019 \mathrm{E}-02$ & 3320733443.95312 \\
\hline $1 \mathrm{H}-2$ & 0.60 & 2.10 & 70.3 & 82.0 & $3.103 \mathrm{E}-02$ & 3320733449.28125 \\
\hline $1 \mathrm{H}-2$ & 0.65 & 2.15 & 81.0 & 86.6 & 3.007E-02 & 3320733454.60937 \\
\hline $1 \mathrm{H}-2$ & 0.70 & 2.20 & 102.6 & 87.5 & 3.007E-02 & 3320733459.93750 \\
\hline $1 \mathrm{H}-2$ & 0.75 & 2.25 & 145.3 & 88.5 & $2.864 \mathrm{E}-02$ & 3320733465.26562 \\
\hline $1 \mathrm{H}-2$ & 0.80 & 2.30 & 229.3 & 89.3 & $2.531 \mathrm{E}-02$ & 3320733470.57812 \\
\hline $1 \mathrm{H}-2$ & 0.85 & 2.35 & 218.3 & 86.1 & $2.059 \mathrm{E}-02$ & 3320733475.90625 \\
\hline $1 \mathrm{H}-2$ & 0.90 & 2.40 & 187.2 & 84.7 & $1.502 \mathrm{E}-02$ & 3320733481.23437 \\
\hline $1 \mathrm{H}-2$ & 0.95 & 2.45 & 215.8 & 85.1 & $1.108 \mathrm{E}-02$ & 3320733486.56250 \\
\hline $1 \mathrm{H}-2$ & 1.00 & 2.50 & 143.6 & 85.2 & $1.118 \mathrm{E}-02$ & 3320733491.87500 \\
\hline $1 \mathrm{H}-2$ & 1.05 & 2.55 & 122.9 & 84.4 & $1.472 \mathrm{E}-02$ & 3320733497.20312 \\
\hline $1 \mathrm{H}-2$ & 1.10 & 2.60 & 205.3 & 87.9 & $2.111 \mathrm{E}-02$ & 3320733502.53125 \\
\hline $1 \mathrm{H}-2$ & 1.15 & 2.65 & 203.6 & 85.7 & $2.704 \mathrm{E}-02$ & 3320733507.85937 \\
\hline $1 \mathrm{H}-2$ & 1.20 & 2.70 & 202.2 & 86.2 & $2.791 \mathrm{E}-02$ & 3320733513.18750 \\
\hline $1 \mathrm{H}-2$ & 1.25 & 2.75 & 214.4 & 87.6 & $2.867 \mathrm{E}-02$ & 3320733518.51562 \\
\hline $1 \mathrm{H}-2$ & 1.30 & 2.80 & 198.6 & 85.7 & $2.897 \mathrm{E}-02$ & 3320733523.82812 \\
\hline $1 \mathrm{H}-2$ & 1.35 & 2.85 & 168.2 & 84.3 & $2.906 \mathrm{E}-02$ & 3320733529.15625 \\
\hline $1 \mathrm{H}-2$ & 1.40 & 2.90 & 135.6 & 86.2 & $2.508 \mathrm{E}-02$ & 3320733534.48437 \\
\hline $1 \mathrm{H}-3$ & 0.10 & 3.10 & 211.5 & 88.5 & $2.562 \mathrm{E}-02$ & 3320736022.75000 \\
\hline $1 \mathrm{H}-3$ & 0.15 & 3.15 & 204.3 & 89.3 & $2.687 \mathrm{E}-02$ & 3320736028.07812 \\
\hline $1 \mathrm{H}-3$ & 0.20 & 3.20 & 223.8 & 87.1 & $2.834 \mathrm{E}-02$ & 3320736033.40625 \\
\hline $1 \mathrm{H}-3$ & 0.25 & 3.25 & 149.5 & 88.2 & $2.814 \mathrm{E}-02$ & 3320736038.71875 \\
\hline $1 \mathrm{H}-3$ & 0.30 & 3.30 & 185.2 & 84.4 & $2.826 \mathrm{E}-02$ & 3320736044.04687 \\
\hline $1 \mathrm{H}-3$ & 0.35 & 3.35 & 172.8 & 59.2 & $3.137 \mathrm{E}-02$ & 3320736049.37500 \\
\hline $1 \mathrm{H}-3$ & 0.40 & 3.40 & 159.0 & 42.9 & $3.185 \mathrm{E}-02$ & 3320736054.70312 \\
\hline $1 \mathrm{H}-3$ & 0.45 & 3.45 & 147.7 & 48.9 & $2.242 \mathrm{E}-02$ & 3320736060.01562 \\
\hline $1 \mathrm{H}-3$ & 0.50 & 3.50 & 151.9 & 61.2 & $2.085 \mathrm{E}-02$ & 3320736065.34375 \\
\hline $1 \mathrm{H}-3$ & 0.55 & 3.55 & 151.5 & 65.9 & $1.957 \mathrm{E}-02$ & 3320736070.67187 \\
\hline $1 \mathrm{H}-3$ & 0.60 & 3.60 & 155.2 & 60.6 & $1.781 \mathrm{E}-02$ & 3320736076.00000 \\
\hline $1 \mathrm{H}-3$ & 0.65 & 3.65 & 163.6 & 54.2 & $1.465 \mathrm{E}-02$ & 3320736081.32812 \\
\hline $2 \mathrm{H}-1$ & 0.10 & 4.00 & 223.8 & 82.0 & $3.708 \mathrm{E}-02$ & 3320744157.64062 \\
\hline $2 \mathrm{H}-1$ & 0.15 & 4.05 & 201.1 & 83.8 & $3.778 \mathrm{E}-02$ & 3320744162.96875 \\
\hline $2 \mathrm{H}-1$ & 0.20 & 4.10 & 216.6 & 85.3 & 3.577E-02 & 3320744168.29687 \\
\hline $2 \mathrm{H}-1$ & 0.25 & 4.15 & 215.6 & 84.9 & 3.407E-02 & 3320744173.60937 \\
\hline $2 \mathrm{H}-1$ & 0.30 & 4.20 & 231.6 & 81.9 & $3.413 \mathrm{E}-02$ & 3320744178.93750 \\
\hline $2 \mathrm{H}-1$ & 0.35 & 4.25 & 217.9 & 79.8 & $3.423 \mathrm{E}-02$ & 3320744184.26562 \\
\hline $2 \mathrm{H}-1$ & 0.40 & 4.30 & 219.9 & 79.5 & $3.364 \mathrm{E}-02$ & 3320744189.59375 \\
\hline $2 \mathrm{H}-1$ & 0.45 & 4.35 & 229.3 & 81.5 & $3.236 \mathrm{E}-02$ & 3320744194.92187 \\
\hline $2 \mathrm{H}-1$ & 0.50 & 4.40 & 216.8 & 83.3 & $3.111 \mathrm{E}-02$ & 3320744200.25000 \\
\hline $2 \mathrm{H}-1$ & 0.55 & 4.45 & 224.9 & 83.0 & $3.274 \mathrm{E}-02$ & 3320744205.56250 \\
\hline $2 \mathrm{H}-1$ & 0.60 & 4.50 & 241.3 & 85.6 & $3.403 \mathrm{E}-02$ & 3320744210.89062 \\
\hline $2 \mathrm{H}-1$ & 0.65 & 4.55 & 233.6 & 84.9 & $3.384 \mathrm{E}-02$ & 3320744216.21875 \\
\hline $2 \mathrm{H}-1$ & 0.70 & 4.60 & 222.7 & 88.7 & $3.559 \mathrm{E}-02$ & 3320744221.54687 \\
\hline $2 \mathrm{H}-1$ & 0.75 & 4.65 & 262.3 & 84.1 & $3.718 \mathrm{E}-02$ & 3320744226.87500 \\
\hline $2 \mathrm{H}-1$ & 0.80 & 4.70 & 219.4 & 84.3 & $3.803 \mathrm{E}-02$ & 3320744232.18750 \\
\hline $2 \mathrm{H}-1$ & 0.85 & 4.75 & 236.3 & 83.9 & 4.059E-02 & 3320744237.51562 \\
\hline
\end{tabular}

Notes: Time $=$ since 1 January 1904. Only a portion of this table appears here. The complete table is available in ASCII. 
Table T13. Paleomagnetic data from archive-half sections, Hole U1332A, at $5 \mathrm{mT}$ AF demagnetization. (See table note.)

\begin{tabular}{|c|c|c|c|c|c|c|}
\hline $\begin{array}{l}\text { Core, } \\
\text { section }\end{array}$ & $\begin{array}{l}\text { Offset } \\
(\mathrm{m})\end{array}$ & $\begin{array}{l}\text { Depth CSF } \\
(\mathrm{m})\end{array}$ & $\begin{array}{c}\text { Declination } \\
\left({ }^{\circ}\right)\end{array}$ & $\begin{array}{c}\text { Inclination } \\
\left({ }^{\circ}\right)\end{array}$ & $\begin{array}{l}\text { Intensity } \\
(\mathrm{A} / \mathrm{m})\end{array}$ & $\begin{array}{l}\text { Time } \\
(s)\end{array}$ \\
\hline \multicolumn{7}{|c|}{ 320-U1332A- } \\
\hline $1 \mathrm{H}-2$ & 0.10 & 1.60 & 183.2 & 10.2 & $5.582 \mathrm{E}-03$ & 3320733923.20312 \\
\hline $1 \mathrm{H}-2$ & 0.15 & 1.65 & 179.9 & 11.7 & $6.416 \mathrm{E}-03$ & 3320733928.51562 \\
\hline $1 \mathrm{H}-2$ & 0.20 & 1.70 & 180.7 & 11.9 & $6.317 \mathrm{E}-03$ & 3320733933.84375 \\
\hline $1 \mathrm{H}-2$ & 0.25 & 1.75 & 182.1 & 28.7 & $2.370 \mathrm{E}-03$ & 3320733939.17187 \\
\hline $1 \mathrm{H}-2$ & 0.30 & 1.80 & 356.1 & 21.3 & $3.417 \mathrm{E}-03$ & 3320733944.50000 \\
\hline $1 \mathrm{H}-2$ & 0.35 & 1.85 & 342.1 & 22.9 & 4.687E-03 & 3320733949.82812 \\
\hline $1 \mathrm{H}-2$ & 0.40 & 1.90 & 341.3 & 18.0 & $6.552 \mathrm{E}-03$ & 3320733955.15625 \\
\hline $1 \mathrm{H}-2$ & 0.45 & 1.95 & 343.3 & 15.9 & $5.840 \mathrm{E}-03$ & 3320733960.46875 \\
\hline $1 \mathrm{H}-2$ & 0.50 & 2.00 & 354.4 & 46.1 & $2.064 \mathrm{E}-03$ & 3320733965.79687 \\
\hline $1 \mathrm{H}-2$ & 0.55 & 2.05 & 126.9 & 78.9 & $2.335 \mathrm{E}-03$ & 3320733971.12500 \\
\hline $1 \mathrm{H}-2$ & 0.60 & 2.10 & 120.6 & 29.8 & $4.442 \mathrm{E}-03$ & 3320733976.45312 \\
\hline $1 \mathrm{H}-2$ & 0.65 & 2.15 & 151.2 & 24.3 & $3.816 \mathrm{E}-03$ & 3320733981.78125 \\
\hline $1 \mathrm{H}-2$ & 0.70 & 2.20 & 160.3 & 21.7 & $5.435 \mathrm{E}-03$ & 3320733987.09375 \\
\hline $1 \mathrm{H}-2$ & 0.75 & 2.25 & 161.2 & 24.2 & 4.893E-03 & 3320733992.42187 \\
\hline $1 \mathrm{H}-2$ & 0.80 & 2.30 & 171.8 & 32.3 & $3.631 \mathrm{E}-03$ & 3320733997.75000 \\
\hline $1 \mathrm{H}-2$ & 0.85 & 2.35 & 186.4 & 32.4 & $3.481 \mathrm{E}-03$ & 3320734003.07812 \\
\hline $1 \mathrm{H}-2$ & 0.90 & 2.40 & 184.5 & 35.7 & $2.585 \mathrm{E}-03$ & 3320734008.40625 \\
\hline $1 \mathrm{H}-2$ & 0.95 & 2.45 & 183.3 & 50.7 & 2.003E-03 & 3320734013.71875 \\
\hline $1 \mathrm{H}-2$ & 1.00 & 2.50 & 179.3 & 41.6 & $1.854 \mathrm{E}-03$ & 3320734019.04687 \\
\hline $1 \mathrm{H}-2$ & 1.05 & 2.55 & 177.9 & 33.0 & $2.326 \mathrm{E}-03$ & 3320734024.37500 \\
\hline $1 \mathrm{H}-2$ & 1.10 & 2.60 & 179.5 & 25.1 & $4.169 \mathrm{E}-03$ & 3320734029.70312 \\
\hline $1 \mathrm{H}-2$ & 1.15 & 2.65 & 182.1 & 24.2 & $5.281 \mathrm{E}-03$ & 3320734035.03125 \\
\hline $1 \mathrm{H}-2$ & 1.20 & 2.70 & 181.5 & 26.8 & $4.681 \mathrm{E}-03$ & 3320734040.34375 \\
\hline $1 \mathrm{H}-2$ & 1.25 & 2.75 & 186.0 & 31.8 & $4.413 \mathrm{E}-03$ & 3320734045.67187 \\
\hline $1 \mathrm{H}-2$ & 1.30 & 2.80 & 183.6 & 21.9 & $5.797 \mathrm{E}-03$ & 3320734051.00000 \\
\hline $1 \mathrm{H}-2$ & 1.35 & 2.85 & 176.5 & 18.8 & $6.540 \mathrm{E}-03$ & 3320734056.32812 \\
\hline $1 \mathrm{H}-2$ & 1.40 & 2.90 & 174.9 & 21.5 & $5.148 \mathrm{E}-03$ & 3320734061.64062 \\
\hline $1 \mathrm{H}-3$ & 0.10 & 3.10 & 191.2 & 47.9 & $4.452 \mathrm{E}-03$ & 3320736407.10937 \\
\hline $1 \mathrm{H}-3$ & 0.15 & 3.15 & 182.6 & 49.2 & 4.377E-03 & 3320736412.43750 \\
\hline $1 \mathrm{H}-3$ & 0.20 & 3.20 & 173.7 & 36.6 & 5.797E-03 & 3320736417.76562 \\
\hline $1 \mathrm{H}-3$ & 0.25 & 3.25 & 172.9 & 40.0 & $5.881 \mathrm{E}-03$ & 3320736423.09375 \\
\hline $1 \mathrm{H}-3$ & 0.30 & 3.30 & 179.8 & 54.6 & $5.298 \mathrm{E}-03$ & 3320736428.42187 \\
\hline $1 \mathrm{H}-3$ & 0.35 & 3.35 & 178.2 & 52.3 & 5.857E-03 & 3320736433.73437 \\
\hline $1 \mathrm{H}-3$ & 0.40 & 3.40 & 164.2 & 36.6 & $6.893 \mathrm{E}-03$ & 3320736439.06250 \\
\hline $1 \mathrm{H}-3$ & 0.45 & 3.45 & 155.4 & 35.1 & $5.112 \mathrm{E}-03$ & 3320736444.39062 \\
\hline $1 \mathrm{H}-3$ & 0.50 & 3.50 & 161.8 & 25.1 & $4.291 \mathrm{E}-03$ & 3320736449.71875 \\
\hline $1 \mathrm{H}-3$ & 0.55 & 3.55 & 165.1 & 12.6 & $5.924 \mathrm{E}-03$ & 3320736455.03125 \\
\hline $1 \mathrm{H}-3$ & 0.60 & 3.60 & 162.5 & 6.2 & $6.891 \mathrm{E}-03$ & 3320736460.35937 \\
\hline $1 \mathrm{H}-3$ & 0.65 & 3.65 & 160.5 & 1.7 & $6.215 \mathrm{E}-03$ & 3320736465.68750 \\
\hline
\end{tabular}

Note: Time $=$ since 1 January 1904. This table is available in ASCII. 
Table T14. Paleomagnetic data from archive-half sections, Hole U1332A, at $10 \mathrm{mT}$ AF demagnetization. (See table note.) (Continued on next page.)

\begin{tabular}{|c|c|c|c|c|c|c|}
\hline $\begin{array}{l}\text { Core, } \\
\text { section }\end{array}$ & $\begin{array}{l}\text { Offset } \\
(\mathrm{m})\end{array}$ & $\begin{array}{l}\text { Depth CSF } \\
(\mathrm{m})\end{array}$ & $\begin{array}{l}\text { Declination } \\
\left({ }^{\circ}\right)\end{array}$ & $\begin{array}{c}\text { Inclination } \\
\left({ }^{\circ}\right)\end{array}$ & $\begin{array}{l}\text { Intensity } \\
(\mathrm{A} / \mathrm{m})\end{array}$ & $\begin{array}{l}\text { Time } \\
(\mathrm{s})\end{array}$ \\
\hline \multicolumn{7}{|c|}{ 320-U1332A- } \\
\hline $1 \mathrm{H}-1$ & 1.05 & 1.05 & 350.3 & -6.0 & $6.767 \mathrm{E}-03$ & 3320732579.18750 \\
\hline $1 \mathrm{H}-1$ & 1.10 & 1.10 & 351.3 & -3.4 & $6.873 \mathrm{E}-03$ & 3320732584.50000 \\
\hline $1 \mathrm{H}-1$ & 1.15 & 1.15 & 354.6 & -1.5 & $6.071 \mathrm{E}-03$ & 3320732589.82812 \\
\hline $1 \mathrm{H}-1$ & 1.20 & 1.20 & 351.4 & 3.1 & 4.114E-03 & 3320732595.15625 \\
\hline $1 \mathrm{H}-1$ & 1.25 & 1.25 & 211.1 & -15.5 & $1.428 \mathrm{E}-03$ & 3320732600.48437 \\
\hline $1 \mathrm{H}-1$ & 1.30 & 1.30 & 172.8 & -9.8 & 5.619E-03 & 3320732605.79687 \\
\hline $1 \mathrm{H}-1$ & 1.35 & 1.35 & 167.7 & -13.4 & 7.773E-03 & 3320732611.12500 \\
\hline $1 \mathrm{H}-1$ & 1.40 & 1.40 & 173.4 & -13.9 & $7.200 \mathrm{E}-03$ & 3320732616.45312 \\
\hline $1 \mathrm{H}-2$ & 0.10 & 1.60 & 181.3 & 1.5 & $6.282 \mathrm{E}-03$ & 3320734549.45312 \\
\hline $1 \mathrm{H}-2$ & 0.15 & 1.65 & 178.9 & 3.0 & $7.041 \mathrm{E}-03$ & 3320734554.76562 \\
\hline $1 \mathrm{H}-2$ & 0.20 & 1.70 & 180.5 & 2.8 & $6.684 \mathrm{E}-03$ & 3320734560.09375 \\
\hline $1 \mathrm{H}-2$ & 0.25 & 1.75 & 180.7 & 4.3 & $2.932 \mathrm{E}-03$ & 3320734565.42187 \\
\hline $1 \mathrm{H}-2$ & 0.30 & 1.80 & 352.7 & 10.9 & $1.415 \mathrm{E}-03$ & 3320734570.75000 \\
\hline $1 \mathrm{H}-2$ & 0.35 & 1.85 & 347.6 & 8.9 & $2.402 \mathrm{E}-03$ & 3320734576.07812 \\
\hline $1 \mathrm{H}-2$ & 0.40 & 1.90 & 343.7 & 9.1 & 4.289E-03 & 3320734581.39062 \\
\hline $1 \mathrm{H}-2$ & 0.45 & 1.95 & 342.1 & 7.0 & $3.940 \mathrm{E}-03$ & 3320734586.71875 \\
\hline $1 \mathrm{H}-2$ & 0.50 & 2.00 & 126.1 & 17.5 & $5.085 \mathrm{E}-04$ & 3320734592.04687 \\
\hline $1 \mathrm{H}-2$ & 0.55 & 2.05 & 145.4 & 5.4 & $2.478 \mathrm{E}-03$ & 3320734597.37500 \\
\hline $1 \mathrm{H}-2$ & 0.60 & 2.10 & 135.8 & 6.0 & 4.352E-03 & 3320734602.70312 \\
\hline $1 \mathrm{H}-2$ & 0.65 & 2.15 & 156.9 & 2.4 & $4.140 \mathrm{E}-03$ & 3320734608.01562 \\
\hline $1 \mathrm{H}-2$ & 0.70 & 2.20 & 159.8 & 6.4 & $5.866 \mathrm{E}-03$ & 3320734613.34375 \\
\hline $1 \mathrm{H}-2$ & 0.75 & 2.25 & 162.1 & 7.3 & $5.889 \mathrm{E}-03$ & 3320734618.67187 \\
\hline $1 \mathrm{H}-2$ & 0.80 & 2.30 & 170.8 & 10.5 & $3.922 \mathrm{E}-03$ & 3320734624.00000 \\
\hline $1 \mathrm{H}-2$ & 0.85 & 2.35 & 181.8 & 11.7 & 3.817E-03 & 3320734629.32812 \\
\hline $1 \mathrm{H}-2$ & 0.90 & 2.40 & 179.4 & 26.3 & $2.233 \mathrm{E}-03$ & 3320734634.64062 \\
\hline $1 \mathrm{H}-2$ & 0.95 & 2.45 & 178.0 & 30.8 & $1.539 \mathrm{E}-03$ & 3320734639.96875 \\
\hline $1 \mathrm{H}-2$ & 1.00 & 2.50 & 177.6 & 16.9 & $1.568 \mathrm{E}-03$ & 3320734645.29687 \\
\hline $1 \mathrm{H}-2$ & 1.05 & 2.55 & 177.5 & 11.2 & 2.257E-03 & 3320734650.62500 \\
\hline $1 \mathrm{H}-2$ & 1.10 & 2.60 & 178.5 & 7.7 & 4.655E-03 & 3320734655.95312 \\
\hline $1 \mathrm{H}-2$ & 1.15 & 2.65 & 178.7 & 4.8 & $6.262 \mathrm{E}-03$ & 3320734661.26562 \\
\hline $1 \mathrm{H}-2$ & 1.20 & 2.70 & 178.1 & 6.8 & $4.722 \mathrm{E}-03$ & 3320734666.59375 \\
\hline $1 \mathrm{H}-2$ & 1.25 & 2.75 & 181.0 & 7.7 & $4.851 \mathrm{E}-03$ & 3320734671.92187 \\
\hline $1 \mathrm{H}-2$ & 1.30 & 2.80 & 180.1 & 3.6 & 7.279E-03 & 3320734677.25000 \\
\hline $1 \mathrm{H}-2$ & 1.35 & 2.85 & 174.7 & 2.5 & $7.325 \mathrm{E}-03$ & 3320734682.57812 \\
\hline $1 \mathrm{H}-2$ & 1.40 & 2.90 & 173.7 & 5.9 & $5.776 \mathrm{E}-03$ & 3320734687.90625 \\
\hline $1 \mathrm{H}-3$ & 0.10 & 3.10 & 185.9 & 21.4 & 4.298E-03 & 3320736746.87500 \\
\hline $1 \mathrm{H}-3$ & 0.15 & 3.15 & 179.6 & 23.2 & $4.110 \mathrm{E}-03$ & 3320736752.20312 \\
\hline $1 \mathrm{H}-3$ & 0.20 & 3.20 & 174.0 & 17.6 & $5.880 \mathrm{E}-03$ & 3320736757.53125 \\
\hline $1 \mathrm{H}-3$ & 0.25 & 3.25 & 172.8 & 20.9 & $5.794 \mathrm{E}-03$ & 3320736762.84375 \\
\hline $1 \mathrm{H}-3$ & 0.30 & 3.30 & 177.2 & 31.0 & $4.521 \mathrm{E}-03$ & 3320736768.17187 \\
\hline $1 \mathrm{H}-3$ & 0.35 & 3.35 & 177.3 & 27.2 & $4.866 \mathrm{E}-03$ & 3320736773.50000 \\
\hline $1 \mathrm{H}-3$ & 0.40 & 3.40 & 172.1 & 23.1 & 4.719E-03 & 3320736778.82812 \\
\hline $1 \mathrm{H}-3$ & 0.45 & 3.45 & 167.2 & 21.8 & $3.429 \mathrm{E}-03$ & 3320736784.14062 \\
\hline $1 \mathrm{H}-3$ & 0.50 & 3.50 & 163.9 & 5.3 & $4.768 \mathrm{E}-03$ & 3320736789.46875 \\
\hline $1 \mathrm{H}-3$ & 0.55 & 3.55 & 164.4 & -3.8 & 5.939E-03 & 3320736794.79687 \\
\hline $1 \mathrm{H}-3$ & 0.60 & 3.60 & 161.1 & -5.6 & $6.744 \mathrm{E}-03$ & 3320736800.12500 \\
\hline $1 \mathrm{H}-3$ & 0.65 & 3.65 & 161.7 & -8.3 & $6.728 \mathrm{E}-03$ & 3320736805.45312 \\
\hline 7H-1 & 0.10 & 51.50 & 10.9 & 68.3 & $3.465 \mathrm{E}-03$ & 3320801263.79687 \\
\hline $7 \mathrm{H}-1$ & 0.15 & 51.55 & 36.2 & 25.0 & $2.320 \mathrm{E}-03$ & 3320801269.12500 \\
\hline 7H-1 & 0.20 & 51.60 & 58.9 & 16.0 & $2.784 \mathrm{E}-03$ & 3320801274.45312 \\
\hline $7 \mathrm{H}-1$ & 0.25 & 51.65 & 62.2 & 13.6 & $3.232 \mathrm{E}-03$ & 3320801279.78125 \\
\hline 7H-1 & 0.30 & 51.70 & 51.0 & 11.8 & 1.817E-03 & 3320801285.10937 \\
\hline 7H-1 & 0.35 & 51.75 & 58.2 & 19.6 & $1.420 \mathrm{E}-03$ & 3320801290.42187 \\
\hline $7 \mathrm{H}-1$ & 0.40 & 51.80 & 53.1 & 14.1 & $2.387 \mathrm{E}-03$ & 3320801295.75000 \\
\hline $7 \mathrm{H}-1$ & 0.45 & 51.85 & 61.0 & 19.6 & $2.833 \mathrm{E}-03$ & 3320801301.07812 \\
\hline $7 \mathrm{H}-1$ & 0.50 & 51.90 & 65.1 & 17.5 & 3.367E-03 & 3320801306.40625 \\
\hline $7 \mathrm{H}-1$ & 0.55 & 51.95 & 56.5 & 16.0 & $3.804 \mathrm{E}-03$ & 3320801311.71875 \\
\hline $7 \mathrm{H}-1$ & 0.60 & 52.00 & 60.4 & 16.3 & $3.370 \mathrm{E}-03$ & 3320801317.04687 \\
\hline $7 \mathrm{H}-1$ & 0.65 & 52.05 & 58.6 & 15.3 & $3.262 \mathrm{E}-03$ & 3320801322.37500 \\
\hline $7 \mathrm{H}-1$ & 0.70 & 52.10 & 62.3 & 23.1 & $3.191 \mathrm{E}-03$ & 3320801327.70312 \\
\hline 7H-1 & 0.75 & 52.15 & 62.6 & 26.6 & $2.964 \mathrm{E}-03$ & 3320801333.03125 \\
\hline $7 \mathrm{H}-1$ & 0.80 & 52.20 & 57.8 & 23.3 & $2.474 \mathrm{E}-03$ & 3320801338.35937 \\
\hline $7 \mathrm{H}-1$ & 0.85 & 52.25 & 56.9 & 19.2 & $2.120 \mathrm{E}-03$ & 3320801343.67187 \\
\hline $7 \mathrm{H}-1$ & 0.90 & 52.30 & 85.6 & 13.9 & $1.541 \mathrm{E}-03$ & 3320801349.00000 \\
\hline $7 \mathrm{H}-1$ & 0.95 & 52.35 & 59.2 & 7.6 & $1.571 \mathrm{E}-03$ & 3320801354.32812 \\
\hline $7 \mathrm{H}-1$ & 1.00 & 52.40 & 59.3 & 6.0 & $1.571 \mathrm{E}-03$ & 3320801359.65625 \\
\hline
\end{tabular}


Table T14 (continued).

\begin{tabular}{|c|c|c|c|c|c|c|}
\hline $\begin{array}{l}\text { Core, } \\
\text { section }\end{array}$ & $\begin{array}{l}\text { Offset } \\
\text { (m) }\end{array}$ & $\begin{array}{l}\text { Depth CSF } \\
(\mathrm{m})\end{array}$ & $\begin{array}{c}\text { Declination } \\
\left({ }^{\circ}\right)\end{array}$ & $\begin{array}{c}\text { Inclination } \\
\left({ }^{\circ}\right)\end{array}$ & $\begin{array}{l}\text { Intensity } \\
(\mathrm{A} / \mathrm{m})\end{array}$ & $\begin{array}{l}\text { Time } \\
(s)\end{array}$ \\
\hline $7 \mathrm{H}-1$ & 1.05 & 52.45 & 59.6 & 2.9 & $1.825 \mathrm{E}-03$ & 3320801364.96875 \\
\hline $7 \mathrm{H}-1$ & 1.10 & 52.50 & 59.1 & 1.3 & $2.259 \mathrm{E}-03$ & 3320801370.29687 \\
\hline $7 \mathrm{H}-1$ & 1.15 & 52.55 & 58.4 & 1.5 & $2.113 \mathrm{E}-03$ & 3320801375.62500 \\
\hline 7H-1 & 1.20 & 52.60 & 59.4 & 1.1 & $2.508 \mathrm{E}-03$ & 3320801380.95312 \\
\hline 7H-1 & 1.25 & 52.65 & 59.1 & 2.4 & $2.614 \mathrm{E}-03$ & 3320801386.31250 \\
\hline 7H-1 & 1.30 & 52.70 & 60.3 & 4.0 & $2.166 \mathrm{E}-03$ & 3320801391.64062 \\
\hline $7 \mathrm{H}-1$ & 1.35 & 52.75 & 61.3 & 3.7 & $2.292 \mathrm{E}-03$ & 3320801396.96875 \\
\hline $7 \mathrm{H}-1$ & 1.40 & 52.80 & 63.4 & 6.7 & $2.800 \mathrm{E}-03$ & 3320801402.29687 \\
\hline $7 \mathrm{H}-2$ & 0.10 & 53.00 & 67.0 & 1.1 & 3.007E-03 & 3320802506.79687 \\
\hline $7 \mathrm{H}-2$ & 0.15 & 53.05 & 73.5 & 1.4 & $2.651 \mathrm{E}-03$ & 3320802512.12500 \\
\hline 7H-2 & 0.20 & 53.10 & 74.2 & 2.9 & $2.124 \mathrm{E}-03$ & 3320802517.45312 \\
\hline $7 \mathrm{H}-2$ & 0.25 & 53.15 & 71.5 & 5.1 & $1.512 \mathrm{E}-03$ & 3320802522.78125 \\
\hline 7H-2 & 0.30 & 53.20 & 71.4 & 5.3 & $1.786 \mathrm{E}-03$ & 3320802528.10937 \\
\hline $7 \mathrm{H}-2$ & 0.35 & 53.25 & 76.3 & 3.3 & $3.252 \mathrm{E}-03$ & 3320802533.42187 \\
\hline 7H-2 & 0.40 & 53.30 & 72.3 & 3.8 & $3.006 \mathrm{E}-03$ & 3320802538.75000 \\
\hline 7H-2 & 0.45 & 53.35 & 73.8 & 4.8 & 2.637E-03 & 3320802544.07812 \\
\hline 7H-2 & 0.50 & 53.40 & 67.3 & 7.3 & $1.479 \mathrm{E}-03$ & 3320802549.39062 \\
\hline 7H-2 & 0.55 & 53.45 & 75.4 & 5.5 & $1.483 \mathrm{E}-03$ & 3320802554.71875 \\
\hline $7 \mathrm{H}-2$ & 0.60 & 53.50 & 75.6 & 5.3 & $1.468 \mathrm{E}-03$ & 3320802560.04687 \\
\hline $7 \mathrm{H}-2$ & 0.65 & 53.55 & 75.6 & 5.0 & $1.601 \mathrm{E}-03$ & 3320802565.35937 \\
\hline $7 \mathrm{H}-2$ & 0.70 & 53.60 & 70.0 & 9.9 & $1.151 \mathrm{E}-03$ & 3320802570.68750 \\
\hline $7 \mathrm{H}-2$ & 0.75 & 53.65 & 72.4 & 22.2 & $3.333 \mathrm{E}-03$ & 3320802576.01562 \\
\hline $7 \mathrm{H}-2$ & 0.80 & 53.70 & 101.0 & 39.7 & $6.749 \mathrm{E}-03$ & 3320802581.34375 \\
\hline $7 \mathrm{H}-2$ & 0.85 & 53.75 & 197.5 & 27.9 & 4.614E-03 & 3320802586.65625 \\
\hline $7 \mathrm{H}-2$ & 0.90 & 53.80 & 34.1 & 47.4 & $6.003 \mathrm{E}-04$ & 3320802591.98437 \\
\hline $7 \mathrm{H}-2$ & 0.95 & 53.85 & 70.7 & 6.8 & $1.538 \mathrm{E}-03$ & 3320802597.31250 \\
\hline 7H-2 & 1.00 & 53.90 & 75.3 & 2.4 & $1.506 \mathrm{E}-03$ & 3320802602.64062 \\
\hline 7H-2 & 1.05 & 53.95 & 82.2 & -3.5 & 1.067E-03 & 3320802607.96875 \\
\hline 7H-2 & 1.10 & 54.00 & 86.3 & 3.4 & 9.267E-04 & 3320802613.29687 \\
\hline 7H-2 & 1.15 & 54.05 & 83.3 & 11.5 & $1.010 \mathrm{E}-03$ & 3320802618.60937 \\
\hline 7H-2 & 1.20 & 54.10 & 83.6 & 10.5 & $1.393 \mathrm{E}-03$ & 3320802623.93750 \\
\hline $7 \mathrm{H}-2$ & 1.25 & 54.15 & 85.0 & 8.3 & $1.408 \mathrm{E}-03$ & 3320802629.26562 \\
\hline $7 \mathrm{H}-2$ & 1.30 & 54.20 & 83.2 & 3.5 & 1.407E-03 & 3320802634.59375 \\
\hline $7 \mathrm{H}-2$ & 1.35 & 54.25 & 82.5 & 1.8 & 1.367E-03 & 3320802639.92187 \\
\hline $7 \mathrm{H}-2$ & 1.40 & 54.30 & 83.4 & 1.5 & 1.487E-03 & 3320802645.25000 \\
\hline
\end{tabular}

Note: Time $=$ since 1 January 1904. This table is available in ASCII. 
Table T15. Paleomagnetic data from archive-half sections, Hole U1332A, at $15 \mathrm{mT}$ AF demagnetization. (See table note.)

\begin{tabular}{|c|c|c|c|c|c|c|}
\hline $\begin{array}{l}\text { Core, } \\
\text { section }\end{array}$ & $\begin{array}{l}\text { Offset } \\
(\mathrm{m})\end{array}$ & $\begin{array}{l}\text { Depth CSF } \\
(\mathrm{m})\end{array}$ & $\begin{array}{l}\text { Declination } \\
\left({ }^{\circ}\right)\end{array}$ & $\begin{array}{c}\text { Inclination } \\
\left(^{(}\right)\end{array}$ & $\begin{array}{l}\text { Intensity } \\
(\mathrm{A} / \mathrm{m})\end{array}$ & $\begin{array}{l}\text { Time } \\
(s)\end{array}$ \\
\hline \multicolumn{7}{|c|}{ 320-U1332A- } \\
\hline $1 \mathrm{H}-2$ & 0.10 & 1.60 & 182.8 & -1.7 & $5.588 \mathrm{E}-03$ & 3320734978.60937 \\
\hline $1 \mathrm{H}-2$ & 0.15 & 1.65 & 179.0 & 1.6 & $6.292 \mathrm{E}-03$ & 3320734983.93750 \\
\hline $1 \mathrm{H}-2$ & 0.20 & 1.70 & 179.8 & 3.0 & $6.296 \mathrm{E}-03$ & 3320734989.25000 \\
\hline $1 \mathrm{H}-2$ & 0.25 & 1.75 & 181.0 & 2.9 & $3.816 \mathrm{E}-03$ & 3320734994.57812 \\
\hline $1 \mathrm{H}-2$ & 0.30 & 1.80 & 198.0 & 34.5 & $3.315 \mathrm{E}-04$ & 3320734999.90625 \\
\hline $1 \mathrm{H}-2$ & 0.35 & 1.85 & 348.2 & 8.9 & $1.677 \mathrm{E}-03$ & 3320735005.23437 \\
\hline $1 \mathrm{H}-2$ & 0.40 & 1.90 & 336.5 & 9.6 & $2.695 \mathrm{E}-03$ & 3320735010.56250 \\
\hline $1 \mathrm{H}-2$ & 0.45 & 1.95 & 340.6 & 7.6 & $3.652 \mathrm{E}-03$ & 3320735015.87500 \\
\hline $1 \mathrm{H}-2$ & 0.50 & 2.00 & 326.6 & 11.3 & 8.375E-04 & 3320735021.20312 \\
\hline $1 \mathrm{H}-2$ & 0.55 & 2.05 & 141.3 & -1.0 & $2.542 \mathrm{E}-03$ & 3320735026.53125 \\
\hline $1 \mathrm{H}-2$ & 0.60 & 2.10 & 142.7 & 1.9 & $3.626 \mathrm{E}-03$ & 3320735031.85937 \\
\hline $1 \mathrm{H}-2$ & 0.65 & 2.15 & 152.4 & 1.2 & $4.258 \mathrm{E}-03$ & 3320735037.18750 \\
\hline $1 \mathrm{H}-2$ & 0.70 & 2.20 & 161.2 & 4.7 & 4.927E-03 & 3320735042.50000 \\
\hline $1 \mathrm{H}-2$ & 0.75 & 2.25 & 161.8 & 7.0 & $5.740 \mathrm{E}-03$ & 3320735047.82812 \\
\hline $1 \mathrm{H}-2$ & 0.80 & 2.30 & 171.3 & 7.7 & $4.718 \mathrm{E}-03$ & 3320735053.15625 \\
\hline $1 \mathrm{H}-2$ & 0.85 & 2.35 & 182.4 & 10.3 & $3.660 \mathrm{E}-03$ & 3320735058.48437 \\
\hline $1 \mathrm{H}-2$ & 0.90 & 2.40 & 180.7 & 13.9 & $2.924 \mathrm{E}-03$ & 3320735063.81250 \\
\hline $1 \mathrm{H}-2$ & 0.95 & 2.45 & 177.8 & 30.6 & $1.432 \mathrm{E}-03$ & 3320735069.12500 \\
\hline $1 \mathrm{H}-2$ & 1.00 & 2.50 & 176.8 & 24.1 & $1.377 \mathrm{E}-03$ & 3320735074.45312 \\
\hline $1 \mathrm{H}-2$ & 1.05 & 2.55 & 176.7 & 11.0 & $1.830 \mathrm{E}-03$ & 3320735079.78125 \\
\hline $1 \mathrm{H}-2$ & 1.10 & 2.60 & 178.0 & 7.0 & $3.900 \mathrm{E}-03$ & 3320735085.10937 \\
\hline $1 \mathrm{H}-2$ & 1.15 & 2.65 & 179.4 & 4.9 & $5.412 \mathrm{E}-03$ & 3320735090.42187 \\
\hline $1 \mathrm{H}-2$ & 1.20 & 2.70 & 178.5 & 4.4 & $5.219 \mathrm{E}-03$ & 3320735095.75000 \\
\hline $1 \mathrm{H}-2$ & 1.25 & 2.75 & 179.7 & 6.4 & $4.443 \mathrm{E}-03$ & 3320735101.07812 \\
\hline $1 \mathrm{H}-2$ & 1.30 & 2.80 & 182.1 & 4.3 & $5.401 \mathrm{E}-03$ & 3320735106.40625 \\
\hline $1 \mathrm{H}-2$ & 1.35 & 2.85 & 177.3 & 1.8 & 7.127E-03 & 3320735111.73437 \\
\hline $1 \mathrm{H}-2$ & 1.40 & 2.90 & 174.2 & 3.2 & $6.568 \mathrm{E}-03$ & 3320735117.06250 \\
\hline $1 \mathrm{H}-3$ & 0.10 & 3.10 & 186.5 & 20.2 & 4.027E-03 & 3320737088.90625 \\
\hline $1 \mathrm{H}-3$ & 0.15 & 3.15 & 179.3 & 22.0 & 3.837E-03 & 3320737094.23437 \\
\hline $1 \mathrm{H}-3$ & 0.20 & 3.20 & 174.1 & 16.2 & $5.646 \mathrm{E}-03$ & 3320737099.56250 \\
\hline $1 \mathrm{H}-3$ & 0.25 & 3.25 & 173.0 & 19.7 & $5.350 \mathrm{E}-03$ & 3320737104.87500 \\
\hline $1 \mathrm{H}-3$ & 0.30 & 3.30 & 177.5 & 28.2 & $4.398 \mathrm{E}-03$ & 3320737110.20312 \\
\hline $1 \mathrm{H}-3$ & 0.35 & 3.35 & 177.0 & 26.3 & $4.518 \mathrm{E}-03$ & 3320737115.53125 \\
\hline $1 \mathrm{H}-3$ & 0.40 & 3.40 & 172.4 & 22.0 & $4.274 \mathrm{E}-03$ & 3320737120.85937 \\
\hline $1 \mathrm{H}-3$ & 0.45 & 3.45 & 168.0 & 18.5 & $3.203 \mathrm{E}-03$ & 3320737126.18750 \\
\hline $1 \mathrm{H}-3$ & 0.50 & 3.50 & 162.0 & 5.5 & $4.718 \mathrm{E}-03$ & 3320737131.50000 \\
\hline $1 \mathrm{H}-3$ & 0.55 & 3.55 & 165.2 & -1.8 & $5.609 \mathrm{E}-03$ & 3320737136.82812 \\
\hline $1 \mathrm{H}-3$ & 0.60 & 3.60 & 159.9 & -3.7 & $6.212 \mathrm{E}-03$ & 3320737142.15625 \\
\hline $1 \mathrm{H}-3$ & 0.65 & 3.65 & 162.2 & -8.4 & $6.117 \mathrm{E}-03$ & 3320737147.48437 \\
\hline
\end{tabular}

Note: Time $=$ since 1 January 1904. This table is available in ASCII. 


\begin{tabular}{|c|c|c|c|c|c|c|c|c|c|c|c|}
\hline \multirow{3}{*}{$\begin{array}{l}\text { Core, } \\
\text { section }\end{array}$} & \multirow{3}{*}{$\begin{array}{l}\text { Offset } \\
(\mathrm{m})\end{array}$} & \multirow{3}{*}{$\begin{array}{l}\text { Depth CSF } \\
(\mathrm{m})\end{array}$} & \multirow{3}{*}{$\begin{array}{l}\text { Declination } \\
\left({ }^{\circ}\right)\end{array}$} & \multirow{3}{*}{$\begin{array}{c}\text { Inclination } \\
\left({ }^{\circ}\right)\end{array}$} & \multirow{3}{*}{$\begin{array}{l}\text { Intensity } \\
(\mathrm{A} / \mathrm{m})\end{array}$} & \multirow{3}{*}{$\begin{array}{l}\text { Time } \\
(\mathrm{s})\end{array}$} & \multicolumn{3}{|c|}{ Declination } & \multirow{2}{*}{\multicolumn{2}{|c|}{$\operatorname{VGP}\left({ }^{\circ}\right)$}} \\
\hline & & & & & & & \multirow{2}{*}{$\begin{array}{l}\text { Core mean } \\
\left({ }^{\circ}\right)\end{array}$} & \multicolumn{2}{|c|}{ Geographical coordinates } & & \\
\hline & & & & & & & & $0^{\circ}-360^{\circ}$ & $-90^{\circ}-270^{\circ}$ & Latitude & Longitude \\
\hline \multicolumn{12}{|c|}{ 320-U1332A- } \\
\hline $1 \mathrm{H}-1$ & 1.05 & 1.05 & 343.5 & -1.5 & $5.12 \mathrm{E}-03$ & 3320733002.92187 & 352.1 & 351.4 & -8.6 & 74.7 & 73.5 \\
\hline $1 \mathrm{H}-1$ & 1.10 & 1.10 & 346.6 & -1.3 & $5.19 \mathrm{E}-03$ & 3320733008.23437 & 352.1 & 354.5 & -5.5 & 76.3 & 62.8 \\
\hline $1 \mathrm{H}-1$ & 1.15 & 1.15 & 346.6 & 1.3 & $4.53 \mathrm{E}-03$ & 3320733013.56250 & 352.1 & 354.5 & -5.5 & 77.5 & 65.2 \\
\hline $1 \mathrm{H}-1$ & 1.20 & 1.20 & 334.5 & 2.2 & $2.61 \mathrm{E}-03$ & 3320733018.89062 & 352.1 & 342.4 & -17.6 & 69.5 & 98.5 \\
\hline $1 \mathrm{H}-1$ & 1.25 & 1.25 & 209.7 & -0.8 & $2.36 \mathrm{E}-03$ & 3320733024.21875 & 352.1 & 217.6 & 217.6 & -50.9 & -216.7 \\
\hline $1 \mathrm{H}-1$ & 1.30 & 1.30 & 180.9 & -8.3 & $4.64 \mathrm{E}-03$ & 3320733029.54687 & 352.1 & 188.8 & 188.8 & -78.3 & -190.2 \\
\hline $1 \mathrm{H}-1$ & 1.35 & 1.35 & 180.3 & -11.4 & $6.30 \mathrm{E}-03$ & 3320733034.85937 & 352.1 & 188.2 & 188.2 & -79.8 & -194.6 \\
\hline $1 \mathrm{H}-1$ & 1.40 & 1.40 & 182.2 & -12.7 & $5.56 \mathrm{E}-03$ & 3320733040.18750 & 352.1 & 190.1 & 190.1 & -78.6 & -203.2 \\
\hline $1 \mathrm{H}-2$ & 0.10 & 1.60 & 183.3 & 0.4 & $4.52 \mathrm{E}-03$ & 3320735404.89062 & 352.1 & 191.2 & 191.2 & -73.6 & -184.4 \\
\hline $1 \mathrm{H}-2$ & 0.15 & 1.65 & 179.6 & 4.1 & $5.50 \mathrm{E}-03$ & 3320735410.21875 & 352.1 & 187.5 & 187.5 & -74.2 & -169.7 \\
\hline $1 \mathrm{H}-2$ & 0.20 & 1.70 & 180.3 & 4.0 & $5.49 \mathrm{E}-03$ & 3320735415.54687 & 352.1 & 188.2 & 188.2 & -73.9 & -172.0 \\
\hline $1 \mathrm{H}-2$ & 0.25 & 1.75 & 181.1 & 3.9 & $3.96 \mathrm{E}-03$ & 3320735420.87500 & 352.1 & 189.0 & 189.0 & -73.5 & -174.5 \\
\hline $1 \mathrm{H}-2$ & 0.30 & 1.80 & 197.5 & 42.5 & $4.06 \mathrm{E}-04$ & 3320735426.20312 & 352.1 & 205.4 & 205.4 & -45.9 & -175.1 \\
\hline $1 \mathrm{H}-2$ & 0.35 & 1.85 & 347.6 & 14.0 & $1.48 \mathrm{E}-03$ & 3320735431.51562 & 352.1 & 355.5 & -4.5 & 83.5 & 82.0 \\
\hline $1 \mathrm{H}-2$ & 0.40 & 1.90 & 332.3 & 15.2 & $2.61 \mathrm{E}-03$ & 3320735436.84375 & 352.1 & 340.2 & -19.8 & 70.1 & 118.7 \\
\hline $1 \mathrm{H}-2$ & 0.45 & 1.95 & 340.5 & 10.1 & $3.22 \mathrm{E}-03$ & 3320735442.17187 & 352.1 & 348.4 & -11.6 & 76.7 & 99.2 \\
\hline $1 \mathrm{H}-2$ & 0.50 & 2.00 & 329.8 & 17.9 & $7.11 \mathrm{E}-04$ & 3320735447.50000 & 352.1 & 337.7 & -22.3 & 67.9 & 124.0 \\
\hline $1 \mathrm{H}-2$ & 0.55 & 2.05 & 159.6 & 3.5 & $2.23 \mathrm{E}-03$ & 3320735452.82812 & 352.1 & 167.5 & 167.5 & -71.5 & -98.0 \\
\hline $1 \mathrm{H}-2$ & 0.60 & 2.10 & 150.9 & 3.1 & $3.14 \mathrm{E}-03$ & 3320735458.14062 & 352.1 & 158.8 & 158.8 & -65.0 & -82.3 \\
\hline $1 \mathrm{H}-2$ & 0.65 & 2.15 & 151.3 & 3.6 & $3.35 \mathrm{E}-03$ & 3320735463.46875 & 352.1 & 159.2 & 159.2 & -65.2 & -83.3 \\
\hline $1 \mathrm{H}-2$ & 0.70 & 2.20 & 163.7 & 7.5 & $4.82 \mathrm{E}-03$ & 3320735468.79687 & 352.1 & 171.6 & 171.6 & -72.2 & -112.5 \\
\hline $1 \mathrm{H}-2$ & 0.75 & 2.25 & 163.2 & 8.9 & $5.00 \mathrm{E}-03$ & 3320735474.12500 & 352.1 & 171.1 & 171.1 & -71.4 & -112.2 \\
\hline $1 \mathrm{H}-2$ & 0.80 & 2.30 & 168.5 & 9.9 & $4.28 \mathrm{E}-03$ & 3320735479.45312 & 352.1 & 176.4 & 176.4 & -72.7 & -128.9 \\
\hline $1 \mathrm{H}-2$ & 0.85 & 2.35 & 182.5 & 13.3 & $3.12 \mathrm{E}-03$ & 3320735484.76562 & 352.1 & 190.4 & 190.4 & -68.7 & -170.6 \\
\hline $1 \mathrm{H}-2$ & 0.90 & 2.40 & 180.5 & 19.6 & $2.11 \mathrm{E}-03$ & 3320735490.09375 & 352.1 & 188.4 & 188.4 & -66.5 & -162.2 \\
\hline $1 \mathrm{H}-2$ & 0.95 & 2.45 & 178.4 & 28.5 & $1.46 \mathrm{E}-03$ & 3320735495.42187 & 352.1 & 186.3 & 186.3 & -62.2 & -154.2 \\
\hline $1 \mathrm{H}-2$ & 1.00 & 2.50 & 176.5 & 25.5 & $1.22 \mathrm{E}-03$ & 3320735500.75000 & 352.1 & 184.4 & 184.4 & -64.3 & -151.0 \\
\hline $1 \mathrm{H}-2$ & 1.05 & 2.55 & 177.3 & 12.9 & $1.60 \mathrm{E}-03$ & 3320735506.07812 & 352.1 & 185.2 & 185.2 & -70.8 & -157.0 \\
\hline $1 \mathrm{H}-2$ & 1.10 & 2.60 & 178.2 & 9.8 & $2.88 \mathrm{E}-03$ & 3320735511.40625 & 352.1 & 186.1 & 186.1 & -72.1 & -161.2 \\
\hline $1 \mathrm{H}-2$ & 1.15 & 2.65 & 179.5 & 6.3 & $4.65 \mathrm{E}-03$ & 3320735516.71875 & 352.1 & 187.4 & 187.4 & -73.2 & -167.6 \\
\hline $1 \mathrm{H}-2$ & 1.20 & 2.70 & 178.4 & 5.9 & $4.52 \mathrm{E}-03$ & 3320735522.04687 & 352.1 & 186.3 & 186.3 & -73.9 & -164.3 \\
\hline $1 \mathrm{H}-2$ & 1.25 & 2.75 & 180.0 & 8.0 & $3.93 \mathrm{E}-03$ & 3320735527.37500 & 352.1 & 187.9 & 187.9 & -72.2 & -167.8 \\
\hline $1 \mathrm{H}-2$ & 1.30 & 2.80 & 180.9 & 5.0 & $5.41 \mathrm{E}-03$ & 3320735532.70312 & 352.1 & 188.8 & 188.8 & -73.1 & -172.9 \\
\hline $1 \mathrm{H}-2$ & 1.35 & 2.85 & 176.5 & 2.2 & $6.18 \mathrm{E}-03$ & 3320735538.01562 & 352.1 & 184.4 & 184.4 & -76.3 & -160.0 \\
\hline $1 \mathrm{H}-2$ & 1.40 & 2.90 & 174.0 & 4.0 & $5.85 \mathrm{E}-03$ & 3320735543.34375 & 352.1 & 181.9 & 181.9 & -76.0 & -148.9 \\
\hline $1 \mathrm{H}-3$ & 0.10 & 3.10 & 182.1 & 23.0 & $3.32 \mathrm{E}-03$ & 3320740103.17187 & 352.1 & 190.0 & 190.0 & -64.1 & -164.0 \\
\hline $1 \mathrm{H}-3$ & 0.15 & 3.15 & 177.9 & 23.5 & $3.80 \mathrm{E}-03$ & 3320740108.50000 & 352.1 & 185.8 & 185.8 & -65.1 & -154.7 \\
\hline $1 \mathrm{H}-3$ & 0.20 & 3.20 & 172.6 & 17.9 & $4.94 \mathrm{E}-03$ & 3320740113.82812 & 352.1 & 180.5 & 180.5 & -68.9 & -142.4 \\
\hline $1 \mathrm{H}-3$ & 0.25 & 3.25 & 173.1 & 23.2 & $4.57 \mathrm{E}-03$ & 3320740119.14062 & 352.1 & 181.0 & 181.0 & -66.0 & -143.5 \\
\hline $1 \mathrm{H}-3$ & 0.30 & 3.30 & 177.4 & 28.2 & $3.95 \mathrm{E}-03$ & 3320740124.46875 & 352.1 & 185.3 & 185.3 & -62.6 & -152.2 \\
\hline $1 \mathrm{H}-3$ & 0.35 & 3.35 & 176.1 & 25.3 & $4.02 \mathrm{E}-03$ & 3320740129.79687 & 352.1 & 184.0 & 184.0 & -64.5 & -150.1 \\
\hline $1 \mathrm{H}-3$ & 0.40 & 3.40 & 170.7 & 23.6 & $3.25 \mathrm{E}-03$ & 3320740135.12500 & 352.1 & 178.6 & 178.6 & -65.7 & -137.7 \\
\hline $1 \mathrm{H}-3$ & 0.45 & 3.45 & 167.9 & 14.1 & $2.84 \mathrm{E}-03$ & 3320740140.45312 & 352.1 & 175.8 & 175.8 & -70.5 & -128.5 \\
\hline $1 \mathrm{H}-3$ & 0.50 & 3.50 & 163.2 & 1.9 & $4.80 \mathrm{E}-03$ & 3320740145.76562 & 352.1 & 171.1 & 171.1 & -74.4 & -106.0 \\
\hline
\end{tabular}


Table T17. Paleomagnetic data from archive-half sections, Hole U1332B, at $0 \mathrm{mT}$ AF demagnetization. (See table notes.)

\begin{tabular}{|c|c|c|c|c|c|c|}
\hline $\begin{array}{l}\text { Core, } \\
\text { section }\end{array}$ & $\begin{array}{l}\text { Offset } \\
(\mathrm{m})\end{array}$ & $\begin{array}{l}\text { Depth CSF } \\
(\mathrm{m})\end{array}$ & $\begin{array}{l}\text { Declination } \\
\left(^{\circ}\right)\end{array}$ & $\begin{array}{c}\text { Inclination } \\
\left(^{\circ}\right)\end{array}$ & $\begin{array}{l}\text { Intensity } \\
(\mathrm{A} / \mathrm{m})\end{array}$ & $\begin{array}{l}\text { Time } \\
(\mathrm{s})\end{array}$ \\
\hline \multicolumn{7}{|c|}{ 320-U1332B- } \\
\hline $1 \mathrm{H}-1$ & 0.100 & 0.10 & 288.2 & -3.9 & $5.674 \mathrm{E}-03$ & 3321020940.82812 \\
\hline $1 \mathrm{H}-1$ & 0.150 & 0.15 & 276.0 & -6.9 & 5.347E-03 & 3321020946.15625 \\
\hline $1 \mathrm{H}-1$ & 0.200 & 0.20 & 287.0 & -7.0 & 4.067E-03 & 3321020951.48437 \\
\hline $1 \mathrm{H}-1$ & 0.250 & 0.25 & 309.1 & -6.9 & $3.350 \mathrm{E}-03$ & 3321020956.81250 \\
\hline $1 \mathrm{H}-1$ & 0.300 & 0.30 & 326.4 & -6.2 & $5.799 \mathrm{E}-03$ & 3321020962.12500 \\
\hline $1 \mathrm{H}-1$ & 0.350 & 0.35 & 327.0 & -1.9 & $6.460 \mathrm{E}-03$ & 3321020967.45312 \\
\hline $1 \mathrm{H}-1$ & 0.400 & 0.40 & 315.3 & 4.4 & $5.510 \mathrm{E}-03$ & 3321020972.78125 \\
\hline $1 \mathrm{H}-1$ & 0.450 & 0.45 & 313.9 & 3.0 & $6.664 \mathrm{E}-03$ & 3321020978.10937 \\
\hline $1 \mathrm{H}-1$ & 0.500 & 0.50 & 317.1 & -0.7 & $7.573 \mathrm{E}-03$ & 3321020983.43750 \\
\hline $1 \mathrm{H}-1$ & 0.550 & 0.55 & 315.6 & 0.5 & $6.765 \mathrm{E}-03$ & 3321020988.76562 \\
\hline $1 \mathrm{H}-1$ & 0.600 & 0.60 & 315.2 & 5.9 & $6.488 \mathrm{E}-03$ & 3321020994.07812 \\
\hline $1 \mathrm{H}-1$ & 0.650 & 0.65 & 321.4 & 8.6 & $8.175 \mathrm{E}-03$ & 3321020999.40625 \\
\hline $1 \mathrm{H}-1$ & 0.700 & 0.70 & 316.7 & 11.0 & $8.355 \mathrm{E}-03$ & 3321021004.73437 \\
\hline $1 \mathrm{H}-1$ & 0.750 & 0.75 & 307.9 & 9.4 & $6.519 \mathrm{E}-03$ & 3321021010.06250 \\
\hline $1 \mathrm{H}-1$ & 0.800 & 0.80 & 313.6 & 4.1 & $6.353 \mathrm{E}-03$ & 3321021015.39062 \\
\hline $1 \mathrm{H}-1$ & 0.850 & 0.85 & 321.9 & 1.5 & 7.192E-03 & 3321021020.70312 \\
\hline $1 \mathrm{H}-1$ & 0.900 & 0.90 & 312.0 & 2.6 & $5.855 \mathrm{E}-03$ & 3321021026.03125 \\
\hline $1 \mathrm{H}-1$ & 0.950 & 0.95 & 311.8 & 5.7 & $6.303 \mathrm{E}-03$ & 3321021031.35937 \\
\hline $1 \mathrm{H}-1$ & 1.000 & 1.00 & 313.2 & 7.8 & $6.802 \mathrm{E}-03$ & 3321021036.68750 \\
\hline $1 \mathrm{H}-1$ & 1.050 & 1.05 & 312.2 & 10.0 & $6.694 \mathrm{E}-03$ & 3321021042.01562 \\
\hline $1 \mathrm{H}-1$ & 1.100 & 1.10 & 289.2 & 14.2 & 4.063E-03 & 3321021047.32812 \\
\hline $1 \mathrm{H}-1$ & 1.150 & 1.15 & 208.1 & 8.7 & 4.497E-03 & 3321021052.65625 \\
\hline $1 \mathrm{H}-1$ & 1.200 & 1.20 & 190.1 & -1.0 & $7.541 \mathrm{E}-03$ & 3321021057.98437 \\
\hline $1 \mathrm{H}-1$ & 1.250 & 1.25 & 190.2 & -1.9 & $6.572 \mathrm{E}-03$ & 3321021063.31250 \\
\hline $1 \mathrm{H}-1$ & 1.300 & 1.30 & 193.1 & -1.0 & $5.616 \mathrm{E}-03$ & 3321021068.62500 \\
\hline $1 \mathrm{H}-1$ & 1.350 & 1.35 & 201.8 & -2.8 & $4.052 \mathrm{E}-03$ & 3321021073.95312 \\
\hline $1 \mathrm{H}-1$ & 1.400 & 1.40 & 202.3 & -3.4 & $3.260 \mathrm{E}-03$ & 3321021079.28125 \\
\hline $1 \mathrm{H}-2$ & 0.100 & 1.60 & 30.3 & 82.1 & $2.700 \mathrm{E}-02$ & 3320985450.07812 \\
\hline $1 \mathrm{H}-2$ & 0.150 & 1.65 & 359.1 & 77.7 & $2.756 \mathrm{E}-02$ & 3320985455.40625 \\
\hline $1 \mathrm{H}-2$ & 0.200 & 1.70 & 344.8 & 71.1 & $2.969 \mathrm{E}-02$ & 3320985460.73437 \\
\hline $1 \mathrm{H}-2$ & 0.250 & 1.75 & 335.3 & 75.5 & $3.076 \mathrm{E}-02$ & 3320985466.04687 \\
\hline $1 \mathrm{H}-2$ & 0.300 & 1.80 & 18.2 & 84.7 & $2.745 \mathrm{E}-02$ & 3320985471.37500 \\
\hline $2 \mathrm{H}-1$ & 0.100 & 2.20 & 103.3 & 85.4 & 7.306E-02 & 3321019643.37500 \\
\hline $2 \mathrm{H}-1$ & 0.150 & 2.25 & 33.8 & 81.4 & $6.623 \mathrm{E}-02$ & 3321019648.70312 \\
\hline $2 \mathrm{H}-1$ & 0.200 & 2.30 & 24.2 & 81.1 & $6.554 \mathrm{E}-02$ & 3321019654.03125 \\
\hline $2 \mathrm{H}-1$ & 0.250 & 2.35 & 358.5 & 82.5 & $6.600 \mathrm{E}-02$ & 3321019659.35937 \\
\hline $2 \mathrm{H}-1$ & 0.300 & 2.40 & 24.5 & 83.2 & $6.121 \mathrm{E}-02$ & 3321019664.68750 \\
\hline $2 \mathrm{H}-1$ & 0.350 & 2.45 & 341.2 & 83.1 & $5.445 \mathrm{E}-02$ & 3321019670.00000 \\
\hline $2 \mathrm{H}-1$ & 0.400 & 2.50 & 308.3 & 81.6 & $5.684 \mathrm{E}-02$ & 3321019675.32812 \\
\hline $2 \mathrm{H}-1$ & 0.450 & 2.55 & 309.6 & 86.8 & $5.561 \mathrm{E}-02$ & 3321019680.65625 \\
\hline $2 \mathrm{H}-1$ & 0.500 & 2.60 & 81.0 & 80.5 & $5.481 \mathrm{E}-02$ & 3321019685.98437 \\
\hline $2 \mathrm{H}-1$ & 0.550 & 2.65 & 87.0 & 79.4 & $5.213 \mathrm{E}-02$ & 3321019691.31250 \\
\hline $2 \mathrm{H}-1$ & 0.600 & 2.70 & 62.9 & 88.5 & $4.792 \mathrm{E}-02$ & 3321019696.62500 \\
\hline $2 \mathrm{H}-1$ & 0.650 & 2.75 & 300.6 & 82.7 & 4.519E-02 & 3321019701.95312 \\
\hline $2 \mathrm{H}-1$ & 0.700 & 2.80 & 296.8 & 79.1 & $4.422 \mathrm{E}-02$ & 3321019707.28125 \\
\hline $2 \mathrm{H}-1$ & 0.750 & 2.85 & 296.1 & 83.1 & $3.924 \mathrm{E}-02$ & 3321019712.60937 \\
\hline $2 \mathrm{H}-1$ & 0.800 & 2.90 & 277.5 & 85.6 & $2.955 \mathrm{E}-02$ & 3321019717.93750 \\
\hline $2 \mathrm{H}-1$ & 0.850 & 2.95 & 298.7 & 85.3 & $2.200 \mathrm{E}-02$ & 3321019723.26562 \\
\hline $2 \mathrm{H}-1$ & 0.900 & 3.00 & 327.3 & 83.0 & $2.681 \mathrm{E}-02$ & 3321019728.57812 \\
\hline $2 \mathrm{H}-1$ & 0.950 & 3.05 & 288.0 & 82.2 & $2.472 \mathrm{E}-02$ & 3321019733.90625 \\
\hline $2 \mathrm{H}-1$ & 1.000 & 3.10 & 295.0 & 79.7 & $2.588 \mathrm{E}-02$ & 3321019739.23437 \\
\hline $2 \mathrm{H}-1$ & 1.050 & 3.15 & 287.8 & 75.4 & $3.243 \mathrm{E}-02$ & 3321019744.56250 \\
\hline $2 \mathrm{H}-1$ & 1.100 & 3.20 & 285.4 & 80.6 & $3.354 \mathrm{E}-02$ & 3321019749.87500 \\
\hline $2 \mathrm{H}-1$ & 1.150 & 3.25 & 292.9 & 81.7 & $3.595 \mathrm{E}-02$ & 3321019755.20312 \\
\hline $2 \mathrm{H}-1$ & 1.200 & 3.30 & 277.4 & 84.5 & $3.773 \mathrm{E}-02$ & 3321019760.53125 \\
\hline $2 \mathrm{H}-1$ & 1.250 & 3.35 & 279.6 & 85.8 & $3.574 \mathrm{E}-02$ & 3321019765.85937 \\
\hline $2 \mathrm{H}-1$ & 1.300 & 3.40 & 292.7 & 86.1 & $3.315 \mathrm{E}-02$ & 3321019771.18750 \\
\hline $2 \mathrm{H}-1$ & 1.350 & 3.45 & 274.0 & 80.9 & $3.238 \mathrm{E}-02$ & 3321019776.50000 \\
\hline $2 \mathrm{H}-1$ & 1.400 & 3.50 & 279.3 & 79.0 & 2.717E-02 & 3321019781.82812 \\
\hline $2 \mathrm{H}-2$ & 0.100 & 3.70 & 280.8 & 83.7 & $1.622 \mathrm{E}-02$ & 3321023792.68750 \\
\hline $2 \mathrm{H}-2$ & 0.150 & 3.75 & 337.4 & 87.6 & $1.243 \mathrm{E}-02$ & 3321023798.01562 \\
\hline $2 \mathrm{H}-2$ & 0.200 & 3.80 & 326.4 & 86.8 & $1.143 \mathrm{E}-02$ & 3321023803.34375 \\
\hline
\end{tabular}

Notes: Time $=$ since 1 January 1904 . Only a portion of this table appears here. The complete table is available in ASCII. 


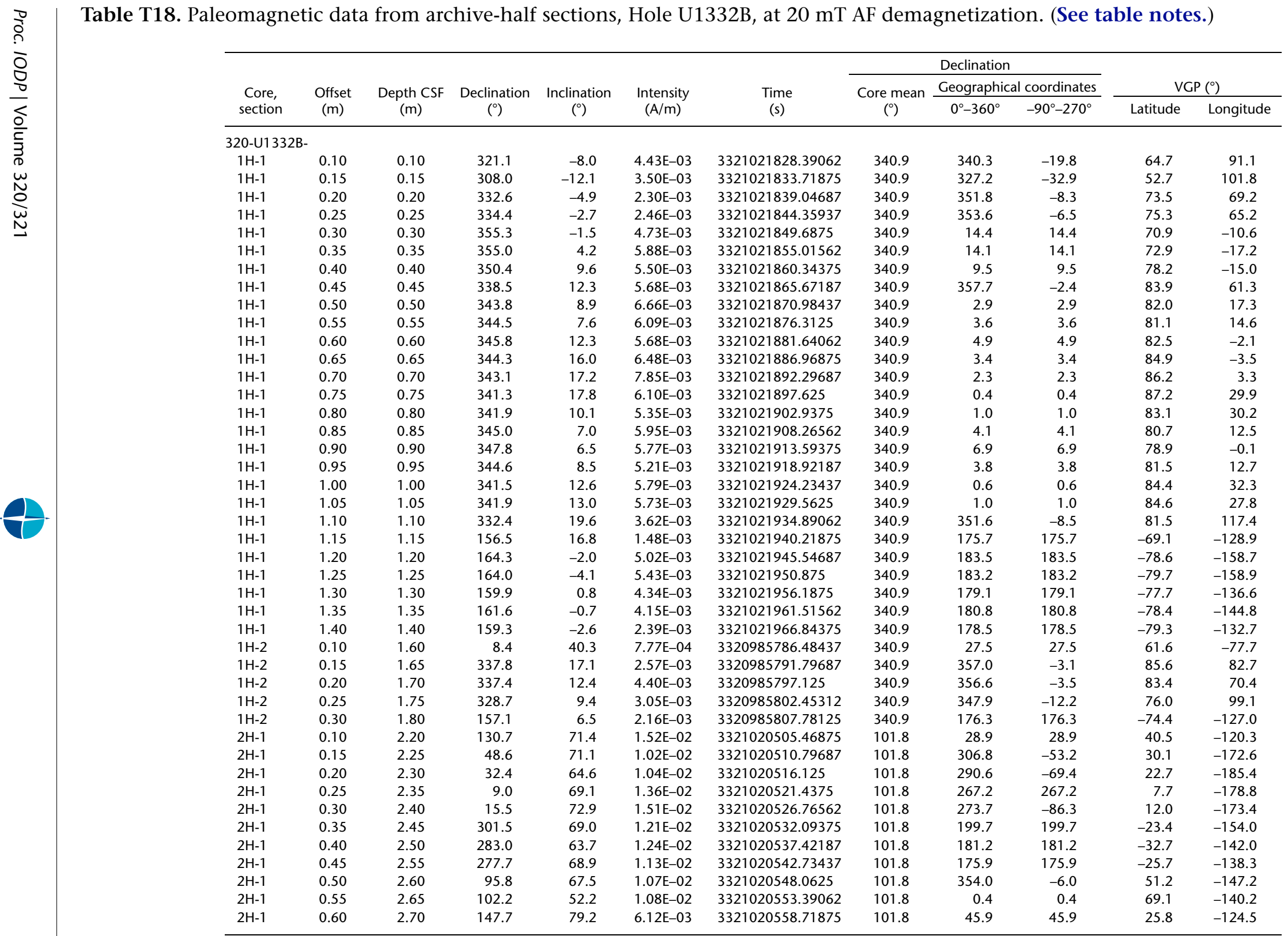

Notes: Time = since 1 January 1904. VGP = virtual geomagnetic pole. Only a portion of this table appears here. The complete table is available in ASCII. 
Table T19. Paleomagnetic data from archive-half sections, Hole U1332C, at $0 \mathrm{mT}$ AF demagnetization. (See table notes.)

\begin{tabular}{|c|c|c|c|c|c|c|}
\hline Core, section & $\begin{array}{l}\text { Offset } \\
(\mathrm{m})\end{array}$ & $\begin{array}{l}\text { Depth CSF } \\
(\mathrm{m})\end{array}$ & $\begin{array}{c}\text { Declination } \\
\left({ }^{\circ}\right)\end{array}$ & $\begin{array}{c}\text { Inclination } \\
\left({ }^{\circ}\right)\end{array}$ & $\begin{array}{c}\text { Intensity } \\
(\mathrm{A} / \mathrm{m})\end{array}$ & $\begin{array}{c}\text { Time } \\
(s)\end{array}$ \\
\hline \multicolumn{7}{|l|}{ 320-U1332C- } \\
\hline $1 \mathrm{H}-1$ & 0.500 & 0.50 & 212.2 & 77.4 & $3.224 \mathrm{E}-02$ & 3321179655.34912 \\
\hline $1 \mathrm{H}-1$ & 0.550 & 0.55 & 202.2 & 79.2 & 3.339E-02 & 3321179660.67725 \\
\hline $1 \mathrm{H}-1$ & 0.600 & 0.60 & 196.8 & 80.1 & $3.558 \mathrm{E}-02$ & 3321179666.00537 \\
\hline $1 \mathrm{H}-1$ & 0.650 & 0.65 & 201.1 & 76.1 & $3.663 \mathrm{E}-02$ & 3321179671.31787 \\
\hline $1 \mathrm{H}-1$ & 0.700 & 0.70 & 190.0 & 75.7 & $3.533 \mathrm{E}-02$ & 3321179676.64600 \\
\hline $1 \mathrm{H}-1$ & 0.750 & 0.75 & 183.4 & 75.3 & 3.513E-02 & 3321179681.97412 \\
\hline $1 \mathrm{H}-1$ & 0.800 & 0.80 & 183.5 & 75.1 & $3.598 \mathrm{E}-02$ & 3321179687.30225 \\
\hline $1 \mathrm{H}-1$ & 0.850 & 0.85 & 176.8 & 75.6 & 3.642E-02 & 3321179692.63037 \\
\hline $1 \mathrm{H}-1$ & 0.900 & 0.90 & 168.4 & 73.3 & 3.517E-02 & 3321179697.94287 \\
\hline $1 \mathrm{H}-1$ & 0.950 & 0.95 & 164.6 & 70.2 & $3.253 \mathrm{E}-02$ & 3321179703.27100 \\
\hline $1 \mathrm{H}-1$ & 1.000 & 1.00 & 159.5 & 71.5 & $3.111 \mathrm{E}-02$ & 3321179708.59912 \\
\hline $1 \mathrm{H}-1$ & 1.050 & 1.05 & 167.3 & 72.4 & $3.265 \mathrm{E}-02$ & 3321179713.92725 \\
\hline $1 \mathrm{H}-1$ & 1.100 & 1.10 & 170.2 & 70.4 & $3.285 \mathrm{E}-02$ & 3321179719.25537 \\
\hline $1 \mathrm{H}-1$ & 1.150 & 1.15 & 161.9 & 67.2 & 2.987E-02 & 3321179724.56787 \\
\hline $1 \mathrm{H}-1$ & 1.200 & 1.20 & 157.9 & 68.0 & $2.894 \mathrm{E}-02$ & 3321179729.89600 \\
\hline $1 \mathrm{H}-1$ & 1.250 & 1.25 & 153.2 & 72.6 & 2.774E-02 & 3321179735.22412 \\
\hline $1 \mathrm{H}-1$ & 1.300 & 1.30 & 146.9 & 74.0 & $2.458 \mathrm{E}-02$ & 3321179740.55225 \\
\hline $1 \mathrm{H}-1$ & 1.350 & 1.35 & 142.1 & 76.2 & $2.086 \mathrm{E}-02$ & 3321179745.88037 \\
\hline $1 \mathrm{H}-1$ & 1.400 & 1.40 & 107.4 & 76.5 & 2.037E-02 & 3321179751.19287 \\
\hline $1 \mathrm{H}-2$ & 0.100 & 1.60 & 139.9 & 65.5 & $1.798 \mathrm{E}-02$ & 3321181317.13037 \\
\hline $1 \mathrm{H}-2$ & 0.150 & 1.65 & 127.2 & 71.8 & $1.676 \mathrm{E}-02$ & 3321181322.44287 \\
\hline $1 \mathrm{H}-2$ & 0.200 & 1.70 & 102.4 & 72.2 & $1.889 \mathrm{E}-02$ & 3321181327.77100 \\
\hline $1 \mathrm{H}-2$ & 0.250 & 1.75 & 87.1 & 74.2 & $1.893 \mathrm{E}-02$ & 3321181333.09912 \\
\hline $1 \mathrm{H}-2$ & 0.300 & 1.80 & 126.8 & 76.1 & $2.085 \mathrm{E}-02$ & 3321181338.42725 \\
\hline $1 \mathrm{H}-2$ & 0.350 & 1.85 & 154.6 & 71.0 & 2.237E-02 & 3321181343.75537 \\
\hline $1 \mathrm{H}-2$ & 0.400 & 1.90 & 158.4 & 66.9 & $2.211 \mathrm{E}-02$ & 3321181349.06787 \\
\hline $1 \mathrm{H}-2$ & 0.450 & 1.95 & 156.4 & 62.5 & $2.559 \mathrm{E}-02$ & 3321181354.39600 \\
\hline $1 \mathrm{H}-2$ & 0.500 & 2.00 & 157.7 & 64.2 & $2.870 \mathrm{E}-02$ & 3321181359.72412 \\
\hline $1 \mathrm{H}-2$ & 0.550 & 2.05 & 135.9 & 75.6 & $2.672 \mathrm{E}-02$ & 3321181365.05225 \\
\hline $1 \mathrm{H}-2$ & 0.600 & 2.10 & 120.7 & 76.3 & $2.738 \mathrm{E}-02$ & 3321181370.38037 \\
\hline $1 \mathrm{H}-2$ & 0.650 & 2.15 & 116.0 & 72.9 & $2.810 \mathrm{E}-02$ & 3321181375.69287 \\
\hline $1 \mathrm{H}-2$ & 0.700 & 2.20 & 117.2 & 67.6 & $2.735 \mathrm{E}-02$ & 3321181381.02100 \\
\hline $1 \mathrm{H}-2$ & 0.750 & 2.25 & 119.8 & 72.5 & $2.241 \mathrm{E}-02$ & 3321181386.34912 \\
\hline $1 \mathrm{H}-2$ & 0.800 & 2.30 & 112.6 & 74.9 & $2.129 \mathrm{E}-02$ & 3321181391.67725 \\
\hline $1 \mathrm{H}-2$ & 0.850 & 2.35 & 116.1 & 71.6 & $1.958 \mathrm{E}-02$ & 3321181397.00537 \\
\hline $1 \mathrm{H}-2$ & 0.900 & 2.40 & 121.7 & 72.9 & 1.623E-02 & 3321181402.31787 \\
\hline $1 \mathrm{H}-2$ & 0.950 & 2.45 & 114.1 & 75.0 & 1.317E-02 & 3321181407.64600 \\
\hline $1 \mathrm{H}-2$ & 1.000 & 2.50 & 103.0 & 77.5 & $1.193 \mathrm{E}-02$ & 3321181412.97412 \\
\hline $1 \mathrm{H}-2$ & 1.050 & 2.55 & 103.3 & 78.9 & 1.779E-02 & 3321181418.30225 \\
\hline $1 \mathrm{H}-2$ & 1.100 & 2.60 & 107.5 & 80.8 & $2.193 \mathrm{E}-02$ & 3321181423.63037 \\
\hline $1 \mathrm{H}-2$ & 1.150 & 2.65 & 95.9 & 80.7 & $2.420 \mathrm{E}-02$ & 3321181428.94287 \\
\hline $1 \mathrm{H}-2$ & 1.200 & 2.70 & 103.5 & 80.2 & $2.506 \mathrm{E}-02$ & 3321181434.27100 \\
\hline $1 \mathrm{H}-2$ & 1.250 & 2.75 & 114.9 & 80.2 & $2.284 \mathrm{E}-02$ & 3321181439.59912 \\
\hline $1 \mathrm{H}-2$ & 1.300 & 2.80 & 109.5 & 77.0 & $2.166 \mathrm{E}-02$ & 3321181444.92725 \\
\hline $1 \mathrm{H}-2$ & 1.350 & 2.85 & 116.5 & 73.3 & 1.795E-02 & 3321181450.23975 \\
\hline $1 \mathrm{H}-2$ & 1.400 & 2.90 & 97.7 & 72.7 & 1.451E-02 & 3321181455.56787 \\
\hline $1 \mathrm{H}-3$ & 0.100 & 3.10 & 113.0 & 66.7 & $2.046 \mathrm{E}-02$ & 3321182222.66162 \\
\hline $1 \mathrm{H}-3$ & 0.150 & 3.15 & 120.1 & 70.3 & $1.948 \mathrm{E}-02$ & 3321182227.98975 \\
\hline $1 \mathrm{H}-3$ & 0.200 & 3.20 & 104.0 & 76.2 & $2.169 \mathrm{E}-02$ & 3321182233.31787 \\
\hline $1 \mathrm{H}-3$ & 0.250 & 3.25 & 96.2 & 67.8 & $2.405 \mathrm{E}-02$ & 3321182238.63037 \\
\hline $1 \mathrm{H}-3$ & 0.300 & 3.30 & 107.5 & 58.0 & $2.464 \mathrm{E}-02$ & 3321182243.95850 \\
\hline $1 \mathrm{H}-3$ & 0.350 & 3.35 & 111.5 & 53.3 & $2.178 \mathrm{E}-02$ & 3321182249.28662 \\
\hline $1 \mathrm{H}-3$ & 0.400 & 3.40 & 111.4 & 57.9 & 1.667E-02 & 3321182254.59912 \\
\hline $1 \mathrm{H}-3$ & 0.450 & 3.45 & 105.6 & 66.1 & $1.209 \mathrm{E}-02$ & 3321182259.92725 \\
\hline $1 \mathrm{H}-3$ & 0.500 & 3.50 & 103.6 & 77.7 & $1.080 \mathrm{E}-02$ & 3321182265.25537 \\
\hline $1 \mathrm{H}-3$ & 0.550 & 3.55 & 97.2 & 72.8 & $1.300 \mathrm{E}-02$ & 3321182270.56787 \\
\hline $1 \mathrm{H}-3$ & 0.600 & 3.60 & 106.4 & 72.3 & $1.361 \mathrm{E}-02$ & 3321182275.89600 \\
\hline $1 \mathrm{H}-3$ & 0.650 & 3.65 & 109.9 & 73.5 & 1.277E-02 & 3321182281.22412 \\
\hline $1 \mathrm{H}-3$ & 0.700 & 3.70 & 137.0 & 78.0 & $9.873 \mathrm{E}-03$ & 3321182286.55225 \\
\hline $1 \mathrm{H}-3$ & 0.750 & 3.75 & 139.1 & 75.3 & $8.195 \mathrm{E}-03$ & 3321182291.86475 \\
\hline
\end{tabular}

Notes: Time $=$ since 1 January 1904. Core 320-U1332C-6H overlaps Core 7H by about $3 \mathrm{~m}$ CSF because Core $6 \mathrm{H}$ was advanced $4 \mathrm{~m}$ but recovered $>7 \mathrm{~m}$ of core. The upper $2.6 \mathrm{~m}$ was slurry (cement and water with mixed sediments). To partially fix the overlap, we have subtracted 2.6 $\mathrm{m}$ from the Core $6 \mathrm{H}$ depths. This brings the top of the good core from Core $6 \mathrm{H}$ up to the base of Core $5 \mathrm{H}$ and reduces the overlap between Cores $6 \mathrm{H}$ and $7 \mathrm{H}$ to about $50 \mathrm{~cm}$. Only a portion of this table appears here. The complete table is available in ASCII. 
Table T20. Paleomagnetic data from archive-half sections, Hole U1332C, at $20 \mathrm{mT}$ AF demagnetization. (See table notes.)

\begin{tabular}{|c|c|c|c|c|c|c|c|c|c|c|c|}
\hline \multirow{3}{*}{$\begin{array}{c}\text { Core, } \\
\text { section }\end{array}$} & \multirow{3}{*}{$\begin{array}{l}\text { Offset } \\
(\mathrm{m})\end{array}$} & \multirow{3}{*}{$\begin{array}{l}\text { Depth CSF } \\
(\mathrm{m})\end{array}$} & \multirow{3}{*}{$\begin{array}{l}\text { Declination } \\
\left({ }^{\circ}\right)\end{array}$} & \multirow{3}{*}{$\begin{array}{c}\text { Inclination } \\
\left({ }^{\circ}\right)\end{array}$} & \multirow{3}{*}{$\begin{array}{l}\text { Intensity } \\
(\mathrm{A} / \mathrm{m})\end{array}$} & \multirow{3}{*}{$\underset{(s)}{\text { Time }}$} & \multicolumn{3}{|c|}{ Declination } & \multirow{2}{*}{\multicolumn{2}{|c|}{$\operatorname{VGP}\left({ }^{\circ}\right)$}} \\
\hline & & & & & & & Core mean & Geogra| & ordinates & & \\
\hline & & & & & & & $\left.{ }^{\circ}\right)$ & $0^{\circ}-360^{\circ}$ & $-90^{\circ}-270^{\circ}$ & Latitude & Longitude \\
\hline \multicolumn{12}{|c|}{ 320-U1332C- } \\
\hline $1 \mathrm{H}-1$ & 0.50 & 0.50 & 210.8 & 42.4 & $6.01 \mathrm{E}-03$ & 3321180839.55225 & 142.9 & 67.9 & 67.9 & 24.9 & -72.8 \\
\hline $1 \mathrm{H}-1$ & 0.55 & 0.55 & 213.7 & 40.5 & $5.97 \mathrm{E}-03$ & 3321180844.88037 & 142.9 & 70.8 & 70.8 & 22.1 & -71.4 \\
\hline $1 \mathrm{H}-1$ & 0.60 & 0.60 & 213.4 & 43.7 & $6.25 \mathrm{E}-03$ & 3321180850.19287 & 142.9 & 70.5 & 70.5 & 22.6 & -74.0 \\
\hline $1 \mathrm{H}-1$ & 0.65 & 0.65 & 211.0 & 38.8 & 7.17E-03 & 3321180855.52100 & 142.9 & 68.1 & 68.1 & 24.6 & -69.9 \\
\hline $1 \mathrm{H}-1$ & 0.70 & 0.70 & 206.7 & 31.7 & $7.15 \mathrm{E}-03$ & 3321180860.84912 & 142.9 & 63.8 & 63.8 & 28.3 & -64.3 \\
\hline $1 \mathrm{H}-1$ & 0.75 & 0.75 & 201.1 & 35.5 & $6.59 \mathrm{E}-03$ & 3321180866.17725 & 142.9 & 58.2 & 58.2 & 33.7 & -66.8 \\
\hline $1 \mathrm{H}-1$ & 0.80 & 0.80 & 200.1 & 37.3 & 7.07E-03 & 3321180871.50537 & 142.9 & 57.2 & 57.2 & 34.7 & -68.3 \\
\hline $1 \mathrm{H}-1$ & 0.85 & 0.85 & 198.8 & 38.2 & $7.41 \mathrm{E}-03$ & 3321180876.81787 & 142.9 & 55.9 & 55.9 & 35.9 & -69.1 \\
\hline $1 \mathrm{H}-1$ & 0.90 & 0.90 & 193.9 & 37.2 & $7.33 \mathrm{E}-03$ & 3321180882.14600 & 142.9 & 51.0 & 51.0 & 40.5 & -68.3 \\
\hline $1 \mathrm{H}-1$ & 0.95 & 0.95 & 193.7 & 31.2 & $6.78 \mathrm{E}-03$ & 3321180887.47412 & 142.9 & 50.8 & 50.8 & 40.7 & -63.1 \\
\hline $1 \mathrm{H}-1$ & 1.00 & 1.00 & 195.5 & 31.0 & $6.17 \mathrm{E}-03$ & 3321180892.80225 & 142.9 & 52.6 & 52.6 & 38.9 & -63.0 \\
\hline $1 \mathrm{H}-1$ & 1.05 & 1.05 & 202.0 & 32.6 & $6.27 \mathrm{E}-03$ & 3321180898.13037 & 142.9 & 59.1 & 59.1 & 32.8 & -64.6 \\
\hline $1 \mathrm{H}-1$ & 1.10 & 1.10 & 201.3 & 35.3 & $6.52 \mathrm{E}-03$ & 3321180903.44287 & 142.9 & 58.4 & 58.4 & 33.5 & -66.7 \\
\hline $1 \mathrm{H}-1$ & 1.15 & 1.15 & 186.5 & 34.0 & $5.90 \mathrm{E}-03$ & 3321180908.77100 & 142.9 & 43.6 & 43.6 & 47.5 & -65.7 \\
\hline $1 \mathrm{H}-1$ & 1.20 & 1.20 & 186.2 & 31.3 & $4.53 \mathrm{E}-03$ & 3321180914.09912 & 142.9 & 43.3 & 43.3 & 47.8 & -63.2 \\
\hline $1 \mathrm{H}-1$ & 1.25 & 1.25 & 188.7 & 27.4 & $3.37 \mathrm{E}-03$ & 3321180919.42725 & 142.9 & 45.8 & 45.8 & 45.4 & -59.8 \\
\hline $1 \mathrm{H}-1$ & 1.30 & 1.30 & 153.0 & 48.9 & $9.38 \mathrm{E}-04$ & 3321180924.75537 & 142.9 & 10.1 & 10.1 & 69.8 & -114.9 \\
\hline $1 \mathrm{H}-1$ & 1.35 & 1.35 & 7.8 & -13.9 & $5.65 \mathrm{E}-04$ & 3321180930.06787 & 142.9 & 224.9 & 224.9 & -45.5 & -229.0 \\
\hline $1 \mathrm{H}-1$ & 1.40 & 1.40 & 5.7 & -30.3 & $2.45 \mathrm{E}-03$ & 3321180935.39600 & 142.9 & 222.8 & 222.8 & -48.3 & 117.8 \\
\hline $1 \mathrm{H}-2$ & 0.10 & 1.60 & 17.0 & -28.9 & $1.60 \mathrm{E}-03$ & 3321181846.00537 & 142.9 & 234.1 & 234.1 & -37.4 & 118.5 \\
\hline $1 \mathrm{H}-2$ & 0.15 & 1.65 & 36.3 & -52.1 & 10.00E-04 & 3321181851.31787 & 142.9 & 253.4 & 253.4 & -20.3 & 98.2 \\
\hline $1 \mathrm{H}-2$ & 0.20 & 1.70 & 7.7 & -30.5 & $3.47 \mathrm{E}-03$ & 3321181856.64600 & 142.9 & 224.8 & 224.8 & -46.4 & 117.6 \\
\hline $1 \mathrm{H}-2$ & 0.25 & 1.75 & 0.1 & -22.5 & $4.05 \mathrm{E}-03$ & 3321181861.97412 & 142.9 & 217.2 & 217.2 & -53.6 & 125.3 \\
\hline $1 \mathrm{H}-2$ & 0.30 & 1.80 & 358.2 & -11.4 & $3.42 \mathrm{E}-03$ & 3321181867.30225 & 142.9 & 215.3 & 215.3 & -54.6 & -224.2 \\
\hline $1 \mathrm{H}-2$ & 0.35 & 1.85 & 144.2 & 32.4 & $7.54 \mathrm{E}-04$ & 3321181872.63037 & 142.9 & 1.3 & 1.3 & 84.2 & -128.8 \\
\hline $1 \mathrm{H}-2$ & 0.40 & 1.90 & 176.0 & 26.4 & $3.54 \mathrm{E}-03$ & 3321181877.94287 & 142.9 & 33.1 & 33.1 & 57.7 & -58.4 \\
\hline $1 \mathrm{H}-2$ & 0.45 & 1.95 & 178.5 & 23.3 & $5.21 \mathrm{E}-03$ & 3321181883.27100 & 142.9 & 35.6 & 35.6 & 55.2 & -55.3 \\
\hline $1 \mathrm{H}-2$ & 0.50 & 2.00 & 179.0 & 25.6 & $5.19 \mathrm{E}-03$ & 3321181888.59912 & 142.9 & 36.1 & 36.1 & 54.8 & -57.6 \\
\hline $1 \mathrm{H}-2$ & 0.55 & 2.05 & 190.2 & 37.5 & $1.68 \mathrm{E}-03$ & 3321181893.92725 & 142.9 & 47.3 & 47.3 & 43.9 & -68.8 \\
\hline $1 \mathrm{H}-2$ & 0.60 & 2.10 & 331.9 & 38.8 & $7.08 \mathrm{E}-04$ & 3321181899.25537 & 142.9 & 189.0 & 189.0 & -55.1 & -155.7 \\
\hline $1 \mathrm{H}-2$ & 0.65 & 2.15 & 344.3 & 5.7 & $1.28 \mathrm{E}-03$ & 3321181904.56787 & 142.9 & 201.4 & 201.4 & -64.1 & -197.6 \\
\hline $1 \mathrm{H}-2$ & 0.70 & 2.20 & 349.3 & 2.2 & $1.33 \mathrm{E}-03$ & 3321181909.89600 & 142.9 & 206.4 & 206.4 & -60.7 & -206.4 \\
\hline $1 \mathrm{H}-2$ & 0.75 & 2.25 & 350.5 & -3.0 & $1.36 \mathrm{E}-03$ & 3321181915.22412 & 142.9 & 207.6 & 207.6 & -60.7 & -212.3 \\
\hline $1 \mathrm{H}-2$ & 0.80 & 2.30 & 347.1 & -11.0 & $2.10 \mathrm{E}-03$ & 3321181920.55225 & 142.9 & 204.2 & 204.2 & -65.3 & -218.2 \\
\hline $1 \mathrm{H}-2$ & 0.85 & 2.35 & 353.2 & -15.1 & $1.32 \mathrm{E}-03$ & 3321181925.88037 & 142.9 & 210.3 & 210.3 & -59.9 & -225.8 \\
\hline $1 \mathrm{H}-2$ & 0.90 & 2.40 & 345.1 & 8.6 & $5.78 \mathrm{E}-04$ & 3321181931.19287 & 142.9 & 202.2 & 202.2 & -62.6 & -196.0 \\
\hline $1 \mathrm{H}-2$ & 0.95 & 2.45 & 345.3 & 11.3 & $5.60 \mathrm{E}-04$ & 3321181936.52100 & 142.9 & 202.4 & 202.4 & -61.6 & -193.9 \\
\hline $1 \mathrm{H}-2$ & 1.00 & 2.50 & 177.1 & 28.2 & $8.08 \mathrm{E}-04$ & 3321181941.84912 & 142.9 & 34.2 & 34.2 & 56.6 & -60.3 \\
\hline $1 \mathrm{H}-2$ & 1.05 & 2.55 & 11.8 & 75.0 & $3.26 \mathrm{E}-04$ & 3321181947.17725 & 142.9 & 228.9 & 228.9 & -7.0 & -162.1 \\
\hline $1 \mathrm{H}-2$ & 1.10 & 2.60 & 315.5 & -3.5 & $1.67 \mathrm{E}-03$ & 3321181952.50537 & 142.9 & 172.6 & 172.6 & -77.5 & -104.7 \\
\hline $1 \mathrm{H}-2$ & 1.15 & 2.65 & 325.4 & -15.5 & $2.58 \mathrm{E}-03$ & 3321181957.81787 & 142.9 & 182.5 & 182.5 & -85.3 & -172.8 \\
\hline $1 \mathrm{H}-2$ & 1.20 & 2.70 & 324.0 & -12.4 & $2.93 \mathrm{E}-03$ & 3321181963.14600 & 142.9 & 181.1 & 181.1 & -84.3 & -152.0 \\
\hline
\end{tabular}

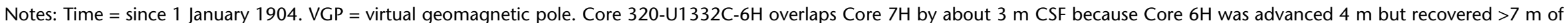
core. The upper $2.6 \mathrm{~m}$ was slurry (cement and water with mixed sediments). To partially fix the overlap, we have subtracted $2.6 \mathrm{~m}$ from the Core $6 \mathrm{H}$ depths. This brings the top of the good core from Core $6 \mathrm{H}$ up to the base of Core $5 \mathrm{H}$ and reduces the overlap between Cores $6 \mathrm{H}$ and $7 \mathrm{H}$ to about $50 \mathrm{~cm}$. Only a portion of this table appears here. The complete table is available in ASCII. 
Table T21. Paleomagnetic results for discrete samples, Hole U1332A. (See table notes.)

\begin{tabular}{|c|c|c|c|c|c|c|c|}
\hline \multirow{3}{*}{$\begin{array}{l}\text { Core, section, } \\
\text { interval }(\mathrm{cm})\end{array}$} & \multirow{3}{*}{$\begin{array}{l}\text { Depth } \\
\text { CSF }(m)\end{array}$} & \multirow{3}{*}{$\begin{array}{c}\text { Demag } \\
(\mathrm{mT})\end{array}$} & \multicolumn{3}{|c|}{ Declination } & \multirow{3}{*}{$\begin{array}{c}\text { Inclination } \\
\left({ }^{\circ}\right)\end{array}$} & \multirow{3}{*}{$\begin{array}{l}\text { Intensity } \\
(\mathrm{A} / \mathrm{m})\end{array}$} \\
\hline & & & \multirow{2}{*}{$\begin{array}{c}\text { Azimuthally } \\
\text { unoriented }\left(^{\circ}\right)\end{array}$} & \multicolumn{2}{|c|}{ Geographical coordinates } & & \\
\hline & & & & $0^{\circ}-360^{\circ}$ & $-90^{\circ}-270^{\circ}$ & & \\
\hline \multicolumn{8}{|l|}{ 320-U1332A- } \\
\hline $1 \mathrm{H}-1,115$ & 1.15 & 0 & 2.7 & 10.6 & 10.6 & 69.9 & $1.640 \mathrm{E}-02$ \\
\hline $1 \mathrm{H}-1,115$ & 1.15 & 5 & 3.2 & 11.1 & 11.1 & 27.7 & $4.998 \mathrm{E}-03$ \\
\hline $1 \mathrm{H}-1,115$ & 1.15 & 10 & -2.6 & 5.3 & 5.3 & 21.4 & $3.622 \mathrm{E}-03$ \\
\hline $1 \mathrm{H}-1,115$ & 1.15 & 15 & 0.7 & 8.6 & 8.6 & 20.8 & $3.232 \mathrm{E}-03$ \\
\hline $1 \mathrm{H}-1,115$ & 1.15 & 20 & 7.7 & 15.6 & 15.6 & 22.8 & $2.835 \mathrm{E}-03$ \\
\hline $1 \mathrm{H}-1,115$ & 1.15 & 25 & -1.7 & 6.2 & 6.2 & 24.1 & $2.476 \mathrm{E}-03$ \\
\hline $1 \mathrm{H}-1,115$ & 1.15 & 30 & -3.9 & 4.0 & 4.0 & 29.4 & $2.013 \mathrm{E}-03$ \\
\hline $1 \mathrm{H}-1,115$ & 1.15 & 35 & -4.7 & 3.2 & 3.2 & 31.6 & $1.460 \mathrm{E}-03$ \\
\hline $1 \mathrm{H}-1,115$ & 1.15 & 40 & -13.6 & -5.7 & -5.7 & 33.4 & $1.282 \mathrm{E}-03$ \\
\hline $1 \mathrm{H}-1,115$ & 1.15 & 50 & 9.6 & 17.5 & 17.5 & 47.7 & $1.095 \mathrm{E}-03$ \\
\hline $1 \mathrm{H}-1,115$ & 1.15 & 60 & -16.4 & -8.5 & -8.5 & 68.0 & $8.940 \mathrm{E}-04$ \\
\hline $1 \mathrm{H}-2,85$ & 2.35 & 0 & 166.2 & 174.2 & 174.2 & 78.5 & $2.939 \mathrm{E}-03$ \\
\hline $1 \mathrm{H}-2,85$ & 2.35 & 5 & 134.4 & 142.3 & 142.3 & 13.3 & $7.681 \mathrm{E}-04$ \\
\hline $1 \mathrm{H}-2,85$ & 2.35 & 10 & -175.7 & -167.8 & 192.2 & -11.0 & $6.415 \mathrm{E}-04$ \\
\hline $1 \mathrm{H}-2,85$ & 2.35 & 15 & 154.5 & 162.4 & 162.4 & -5.1 & 7.006E-04 \\
\hline $1 \mathrm{H}-2,85$ & 2.35 & 20 & 134.5 & 142.4 & 142.4 & -7.7 & 7.736E-04 \\
\hline $1 \mathrm{H}-2,85$ & 2.35 & 25 & 161.9 & 169.8 & 169.8 & -5.0 & $4.870 \mathrm{E}-04$ \\
\hline $1 \mathrm{H}-2,85$ & 2.35 & 30 & 163.3 & 171.2 & 171.2 & 9.8 & $4.524 \mathrm{E}-04$ \\
\hline $1 \mathrm{H}-2,85$ & 2.35 & 35 & 155.6 & 163.5 & 163.5 & 6.6 & $3.140 \mathrm{E}-04$ \\
\hline $1 \mathrm{H}-2,85$ & 2.35 & 40 & 169.3 & 177.2 & 177.2 & 21.6 & $3.722 \mathrm{E}-04$ \\
\hline $1 \mathrm{H}-2,85$ & 2.35 & 50 & 105.1 & 113.0 & 113.0 & 30.5 & $3.404 \mathrm{E}-04$ \\
\hline $1 \mathrm{H}-2,85$ & 2.35 & 60 & 146.0 & 153.9 & 153.9 & 50.0 & $3.473 \mathrm{E}-04$ \\
\hline $2 \mathrm{H}-1,85$ & 4.75 & 0 & 0.1 & 332.2 & -27.8 & 77.9 & $9.503 \mathrm{E}-03$ \\
\hline $2 \mathrm{H}-1,85$ & 4.75 & 5 & -10.6 & 321.4 & -38.6 & -12.2 & $1.416 \mathrm{E}-03$ \\
\hline $2 \mathrm{H}-1,85$ & 4.75 & 10 & -29.0 & 303.0 & -57.0 & -48.7 & $2.130 \mathrm{E}-03$ \\
\hline $2 \mathrm{H}-1,85$ & 4.75 & 15 & -16.8 & 315.2 & -44.8 & -49.2 & $1.917 \mathrm{E}-03$ \\
\hline $2 \mathrm{H}-1,85$ & 4.75 & 20 & 11.8 & 343.8 & -16.2 & -43.9 & $1.559 \mathrm{E}-03$ \\
\hline $2 \mathrm{H}-1,85$ & 4.75 & 25 & -5.3 & 326.7 & -33.3 & -42.7 & $1.205 \mathrm{E}-03$ \\
\hline $2 \mathrm{H}-1,85$ & 4.75 & 30 & -20.7 & 311.4 & -48.6 & -29.4 & $9.272 \mathrm{E}-04$ \\
\hline $2 \mathrm{H}-1,85$ & 4.75 & 35 & -23.5 & 308.6 & -51.4 & -20.1 & $6.954 \mathrm{E}-04$ \\
\hline $2 \mathrm{H}-1,85$ & 4.75 & 40 & -15.4 & 316.6 & -43.4 & 20.7 & $5.720 \mathrm{E}-04$ \\
\hline $2 \mathrm{H}-1,85$ & 4.75 & 50 & 71.3 & 43.4 & 43.4 & 43.2 & $2.982 \mathrm{E}-04$ \\
\hline $2 \mathrm{H}-1,85$ & 4.75 & 60 & 20.5 & 352.6 & -7.4 & 67.6 & $1.244 \mathrm{E}-03$ \\
\hline $2 \mathrm{H}-2,85$ & 6.25 & 0 & 18.5 & 350.5 & -9.5 & 83.6 & $1.540 \mathrm{E}-02$ \\
\hline $2 \mathrm{H}-2,85$ & 6.25 & 5 & 50.2 & 22.3 & 22.3 & 14.2 & $1.677 \mathrm{E}-03$ \\
\hline $2 \mathrm{H}-2,85$ & 6.25 & 10 & 46.6 & 18.6 & 18.6 & -27.1 & $1.978 \mathrm{E}-03$ \\
\hline $2 \mathrm{H}-2,85$ & 6.25 & 15 & 55.6 & 27.6 & 27.6 & -25.6 & $2.178 \mathrm{E}-03$ \\
\hline $2 \mathrm{H}-2,85$ & 6.25 & 20 & 54.2 & 26.3 & 26.3 & -22.3 & $2.145 \mathrm{E}-03$ \\
\hline $2 \mathrm{H}-2,85$ & 6.25 & 25 & 44.0 & 16.0 & 16.0 & -24.9 & $1.440 \mathrm{E}-03$ \\
\hline $2 \mathrm{H}-2,85$ & 6.25 & 30 & 39.6 & 11.7 & 11.7 & -16.7 & $9.639 \mathrm{E}-04$ \\
\hline $2 \mathrm{H}-2,85$ & 6.25 & 35 & 47.1 & 19.1 & 19.1 & -9.3 & $6.947 \mathrm{E}-04$ \\
\hline $2 \mathrm{H}-2,85$ & 6.25 & 40 & 22.4 & 354.5 & -5.5 & 12.2 & $3.298 \mathrm{E}-04$ \\
\hline $2 \mathrm{H}-2,85$ & 6.25 & 50 & 43.8 & 15.9 & 15.9 & 54.2 & $4.785 \mathrm{E}-04$ \\
\hline $2 \mathrm{H}-2,85$ & 6.25 & 60 & 55.3 & 27.3 & 27.3 & 78.5 & $7.408 \mathrm{E}-04$ \\
\hline $2 \mathrm{H}-5,85$ & 10.75 & 0 & -63.7 & 268.4 & 268.4 & -61.6 & $2.171 \mathrm{E}-02$ \\
\hline $2 \mathrm{H}-5,85$ & 10.75 & 5 & -47.7 & 284.4 & -75.6 & -48.6 & $7.862 \mathrm{E}-03$ \\
\hline $2 \mathrm{H}-5,85$ & 10.75 & 10 & -50.8 & 281.2 & -78.8 & -26.0 & $4.105 \mathrm{E}-03$ \\
\hline $2 \mathrm{H}-5,85$ & 10.75 & 15 & -45.0 & 287.0 & -73.0 & -25.7 & $2.998 \mathrm{E}-03$ \\
\hline $2 \mathrm{H}-5,85$ & 10.75 & 20 & -47.2 & 284.8 & -75.2 & -23.4 & $2.406 \mathrm{E}-03$ \\
\hline $2 \mathrm{H}-5,85$ & 10.75 & 25 & -48.0 & 284.0 & -76.0 & -15.5 & $1.954 \mathrm{E}-03$ \\
\hline $2 \mathrm{H}-5,85$ & 10.75 & 30 & -50.1 & 281.9 & -78.1 & -1.8 & $1.577 \mathrm{E}-03$ \\
\hline $2 \mathrm{H}-5,85$ & 10.75 & 35 & -49.1 & 283.0 & -77.0 & 2.5 & $9.856 \mathrm{E}-04$ \\
\hline $2 \mathrm{H}-5,85$ & 10.75 & 40 & -64.1 & 267.9 & 267.9 & 20.2 & $6.986 \mathrm{E}-04$ \\
\hline $2 \mathrm{H}-5,85$ & 10.75 & 50 & -42.0 & 290.0 & -70.0 & 51.6 & $7.502 \mathrm{E}-04$ \\
\hline $2 \mathrm{H}-5,85$ & 10.75 & 60 & -42.7 & 289.3 & -70.7 & 71.9 & $1.015 \mathrm{E}-03$ \\
\hline $2 \mathrm{H}-6,85$ & 12.25 & 0 & 150.0 & 122.1 & 122.1 & -72.2 & $1.208 \mathrm{E}-02$ \\
\hline $2 \mathrm{H}-6,85$ & 12.25 & 5 & 139.8 & 111.8 & 111.8 & -27.4 & $3.612 \mathrm{E}-03$ \\
\hline $2 \mathrm{H}-6,85$ & 12.25 & 10 & 148.2 & 120.2 & 120.2 & -16.7 & $2.335 \mathrm{E}-03$ \\
\hline $2 \mathrm{H}-6,85$ & 12.25 & 15 & 148.2 & 120.2 & 120.2 & -10.8 & $1.845 \mathrm{E}-03$ \\
\hline $2 \mathrm{H}-6,85$ & 12.25 & 20 & 143.6 & 115.6 & 115.6 & -5.8 & $1.549 \mathrm{E}-03$ \\
\hline $2 \mathrm{H}-6,85$ & 12.25 & 25 & 146.2 & 118.3 & 118.3 & 3.1 & $1.115 \mathrm{E}-03$ \\
\hline $2 \mathrm{H}-6,85$ & 12.25 & 30 & 156.8 & 128.8 & 128.8 & 14.8 & $6.562 \mathrm{E}-04$ \\
\hline
\end{tabular}

Notes: Only a portion of this table appears here. The complete table is available in ASCII. 
Table T22. Principal component analysis (PCA) results for paleomagnetic data, Hole U1332A. (See table notes.) (Continued on next page.)

\begin{tabular}{|c|c|c|c|c|c|c|c|c|}
\hline \multirow{4}{*}{$\begin{array}{l}\text { Core, section, } \\
\text { interval }(\mathrm{cm})\end{array}$} & \multirow{4}{*}{$\begin{array}{l}\text { Depth } \\
\operatorname{CSF}(m)\end{array}$} & \multicolumn{5}{|c|}{ PCA } & \multirow{3}{*}{\multicolumn{2}{|c|}{$\begin{array}{l}\text { Archive-half section at } 20 \mathrm{~m} \\
\mathrm{AF} \text { demagnetization }\left({ }^{\circ}\right) \\
\end{array}$}} \\
\hline & & \multicolumn{2}{|c|}{ Declination } & \multirow{3}{*}{$\begin{array}{l}\text { Inclination } \\
\left({ }^{\circ}\right)\end{array}$} & \multirow{3}{*}{$\begin{array}{c}\text { MAD } \\
\left({ }^{\circ}\right)\end{array}$} & \multirow{3}{*}{$\begin{array}{l}\text { Range } \\
(\mathrm{mT})\end{array}$} & & \\
\hline & & \multirow{2}{*}{$\begin{array}{l}\text { Azimuthally } \\
\text { unoriented }\left({ }^{\circ}\right)\end{array}$} & \multirow{2}{*}{$\begin{array}{c}\text { Geographical } \\
\text { coordinates } \\
\left(0^{\circ}-360^{\circ}\right)\end{array}$} & & & & & \\
\hline & & & & & & & Declination & Inclination \\
\hline \multicolumn{9}{|l|}{ 320-U1332A- } \\
\hline $1 \mathrm{H}-1,115$ & 1.15 & 2.8 & 10.7 & 12.8 & 13.1 & $10-35$ & 346.6 & 1.3 \\
\hline $1 \mathrm{H}-2,85$ & 2.35 & NA & NA & NA & NA & NA & 182.5 & 13.3 \\
\hline $2 \mathrm{H}-1,85$ & 4.75 & NA & NA & NA & NA & NA & 209.6 & 34.0 \\
\hline $2 \mathrm{H}-2,85$ & 6.25 & 45.8 & 17.8 & -40.5 & 10.3 & $25-50$ & 211.0 & 36.2 \\
\hline $2 \mathrm{H}-5,85$ & 10.75 & 312.9 & 284.9 & -36.1 & 7.7 & $10-40$ & 77.8 & 61.9 \\
\hline $2 \mathrm{H}-6,85$ & 12.25 & 146.8 & 118.9 & -24.2 & 9.9 & $10-35$ & 74.6 & 67.6 \\
\hline $3 \mathrm{H}-1,95$ & 14.35 & 0.6 & 204.3 & -4.0 & 7.8 & $10-35$ & 0.1 & -2.1 \\
\hline $3 \mathrm{H}-2,85$ & 15.75 & 346.1 & 189.8 & 0.9 & 8.6 & $10-35$ & 344.2 & -8.8 \\
\hline $3 \mathrm{H}-4,85$ & 18.75 & 325.9 & 169.6 & -25.6 & 10.0 & $10-30$ & 306.5 & -2.3 \\
\hline $3 \mathrm{H}-5,85$ & 20.25 & NA & NA & NA & NA & NA & 300.1 & 4.6 \\
\hline $3 \mathrm{H}-6,85$ & 21.75 & 159.8 & 3.5 & 17.5 & 10.1 & $5-40$ & 161.3 & 14.8 \\
\hline $3 \mathrm{H}-7,65$ & 23.05 & NA & NA & NA & NA & NA & 332.9 & 7.9 \\
\hline $4 \mathrm{H}-1,85$ & 23.75 & 269.8 & 183.2 & 0.9 & 7.5 & $10-30$ & 269.7 & 12.2 \\
\hline $4 \mathrm{H}-2,85$ & 25.25 & 81.2 & 354.5 & 2.3 & 3.7 & $10-40$ & 78.7 & 11.2 \\
\hline $4 \mathrm{H}-4,85$ & 28.25 & 91.2 & 4.6 & 4.9 & 3.6 & $10-35$ & 83.0 & 14.1 \\
\hline $4 \mathrm{H}-5,85$ & 29.75 & 83.8 & 357.1 & 17.7 & 9.5 & $5-35$ & 83.2 & 22.5 \\
\hline $4 \mathrm{H}-6,85$ & 31.25 & 259.3 & 172.6 & -0.8 & 9.6 & $10-30$ & 273.1 & 15.5 \\
\hline $4 \mathrm{H}-7,60$ & 32.50 & 102.4 & 15.7 & 6.6 & 5.3 & $10-35$ & 107.7 & 20.2 \\
\hline $5 \mathrm{H}-1,85$ & 33.25 & 319.9 & 334.0 & 0.1 & 11.8 & $10-50$ & 323.0 & 15.8 \\
\hline $5 \mathrm{H}-2,85$ & 34.75 & NA & NA & NA & NA & NA & 161.8 & 17.3 \\
\hline $5 \mathrm{H}-4,85$ & 37.75 & NA & NA & NA & NA & NA & 167.6 & 21.9 \\
\hline $5 \mathrm{H}-5,85$ & 39.25 & 173.7 & 187.8 & 2.6 & 5.0 & $10-30$ & 177.5 & 5.3 \\
\hline $5 \mathrm{H}-6,85$ & 40.75 & 180.8 & 194.9 & -6.6 & 8.7 & $10-30$ & 183.5 & 6.7 \\
\hline $5 \mathrm{H}-7,83$ & 42.23 & NA & NA & NA & NA & $10-30$ & & \\
\hline $6 \mathrm{H}-1,115$ & 43.05 & NA & NA & NA & NA & $15-60$ & 12.0 & 0.6 \\
\hline $6 \mathrm{H}-2,85$ & 44.25 & NA & NA & NA & NA & $10-50$ & 203.9 & -8.9 \\
\hline $6 \mathrm{H}-4,85$ & 47.25 & 186.9 & 354.3 & -0.4 & 4.0 & $10-30$ & 187.6 & 11.8 \\
\hline $6 \mathrm{H}-5,85$ & 48.75 & NA & NA & NA & NA & NA & 21.4 & 0.6 \\
\hline $6 \mathrm{H}-6,85$ & 50.25 & NA & NA & NA & NA & NA & 13.9 & 3.6 \\
\hline $6 \mathrm{H}-7,45$ & 51.35 & 23.3 & 190.7 & 3.5 & 9.8 & $10-40$ & 20.3 & -3.7 \\
\hline $7 \mathrm{H}-1,85$ & 52.25 & 57.0 & 155.9 & -15.1 & 13.7 & $15-40$ & 57.4 & 6.2 \\
\hline $7 \mathrm{H}-2,85$ & 53.75 & NA & NA & NA & NA & NA & 139.7 & 31.8 \\
\hline $7 \mathrm{H}-4,85$ & 56.75 & 77.4 & 176.3 & 0.8 & 8.4 & $5-50$ & 67.0 & -2.6 \\
\hline $7 \mathrm{H}-5,85$ & 58.25 & 89.1 & 188.0 & -3.7 & 9.9 & $15-35$ & 93.0 & 0.0 \\
\hline $7 \mathrm{H}-6,85$ & 59.75 & 108.7 & 207.6 & -8.6 & 8.4 & $20-40$ & 122.7 & 9.8 \\
\hline $7 \mathrm{H}-7,45$ & 60.85 & NA & NA & NA & NA & NA & 148.6 & 16.9 \\
\hline $8 \mathrm{H}-2,85$ & 63.25 & NA & NA & NA & NA & NA & 332.2 & -4.0 \\
\hline $8 \mathrm{H}-4,85$ & 66.25 & 330.0 & 167.7 & 4.5 & 8.1 & $10-40$ & 338.7 & -4.5 \\
\hline $8 \mathrm{H}-5,85$ & 67.75 & NA & NA & NA & NA & NA & 172.8 & 14.4 \\
\hline $8 \mathrm{H}-6,85$ & 69.25 & 174.0 & 11.8 & 6.4 & 13.6 & $10-35$ & 174.2 & 17.7 \\
\hline $8 \mathrm{H}-7,45$ & 70.35 & NA & NA & NA & NA & NA & 176.5 & 18.3 \\
\hline $9 \mathrm{H}-1,85$ & 71.25 & 275.8 & 171.3 & -5.1 & 4.4 & $10-30$ & 282.0 & -1.7 \\
\hline $9 \mathrm{H}-2,85$ & 72.75 & 90.0 & 345.5 & 1.4 & 4.9 & $10-40$ & 94.8 & 9.2 \\
\hline $9 \mathrm{H}-4,135$ & 76.25 & 271.9 & 167.4 & -2.1 & 2.3 & $10-30$ & 283.4 & -2.7 \\
\hline $9 \mathrm{H}-5,85$ & 77.25 & 283.1 & 178.6 & 3.9 & 3.1 & $10-40$ & 283.5 & -0.1 \\
\hline $9 \mathrm{H}-6,85$ & 78.75 & 299.7 & 195.2 & -1.1 & 5.1 & $10-30$ & 291.6 & -5.3 \\
\hline $9 \mathrm{H}-7,45$ & 79.85 & 115.9 & 11.4 & 9.0 & 3.8 & $10-30$ & 116.6 & 9.4 \\
\hline $10 \mathrm{H}-1,95$ & 80.85 & 307.19 & 185.7 & -7.63 & 3.6 & $10-30$ & 304.5 & 1.1 \\
\hline $10 \mathrm{H}-2,85$ & 82.25 & 303.95 & 182.5 & -7.37 & 7.8 & $10-30$ & 306 & 2 \\
\hline $10 \mathrm{H}-4,85$ & 85.25 & 115.1 & 353.6 & 7.5 & 3.8 & $10-30$ & 115.4 & 10.3 \\
\hline $10 \mathrm{H}-5,85$ & 86.75 & 301.2 & 179.7 & -1.8 & 6.4 & $10-30$ & 306.5 & 2.7 \\
\hline $10 \mathrm{H}-6,85$ & 88.25 & 127.6 & 6.1 & 7.1 & 5.8 & $10-30$ & 128.5 & 9.3 \\
\hline $10 \mathrm{H}-7,50$ & 89.40 & 126.71 & 5.2 & 2.82 & 6.9 & $10-30$ & 127 & 6 \\
\hline $11 \mathrm{H}-2,85$ & 91.75 & 264.37 & 1.1 & 2.68 & 2.7 & $10-30$ & 269.2 & 8.5 \\
\hline $11 \mathrm{H}-4,85$ & 94.75 & 264.05 & 0.7 & 0.68 & 4.3 & $15-35$ & 263.8 & 8.2 \\
\hline $11 \mathrm{H}-5,85$ & 96.25 & 79.96 & 176.7 & -2.50 & 7.4 & $10-30$ & 77.50 & 5.20 \\
\hline $11 \mathrm{H}-6,85$ & 97.75 & 261.9 & 358.6 & 0.0 & 4.9 & $10-40$ & 256.5 & 10.2 \\
\hline $12 \mathrm{H}-2,85$ & 101.25 & 286.4 & 353.3 & -1.8 & 3.0 & $20-50$ & 292.3 & 2.4 \\
\hline $12 \mathrm{H}-4,85$ & 104.25 & 297.8 & 4.6 & -6.0 & 3.9 & $15-40$ & 290.2 & 9.7 \\
\hline $12 \mathrm{H}-5,85$ & 105.75 & 303.4 & 10.3 & 6.9 & 5.6 & $10-40$ & 296.4 & 7.6 \\
\hline $12 \mathrm{H}-6,85$ & 107.25 & 131.0 & 197.9 & 4.2 & 4.5 & $15-40$ & 123.1 & -0.5 \\
\hline $12 \mathrm{H}-7,50$ & 108.20 & 118.35 & 185.2 & 5.83 & 4.1 & $10-40$ & & \\
\hline $13 \mathrm{H}-1,85$ & 109.25 & 88.0 & 169.0 & -6.5 & 6.7 & $20-40$ & 102.7 & 18.3 \\
\hline
\end{tabular}


Table T22 (continued).

\begin{tabular}{|c|c|c|c|c|c|c|c|c|}
\hline \multirow{4}{*}{$\begin{array}{l}\text { Core, section, } \\
\text { interval }(\mathrm{cm})\end{array}$} & \multirow{4}{*}{$\begin{array}{l}\text { Depth } \\
\text { CSF }(m)\end{array}$} & \multicolumn{5}{|c|}{ PCA } & & \\
\hline & & \multicolumn{2}{|c|}{ Declination } & \multirow{3}{*}{$\begin{array}{c}\text { Inclination } \\
\left(\left(^{\circ}\right)\right.\end{array}$} & \multirow{3}{*}{$\begin{array}{c}\text { MAD } \\
\left({ }^{\circ}\right)\end{array}$} & \multirow{3}{*}{$\begin{array}{l}\text { Range } \\
(\mathrm{mT})\end{array}$} & \multirow{2}{*}{\multicolumn{2}{|c|}{$\begin{array}{c}\text { Archive-half section at } 20 \mathrm{mT} \\
\mathrm{AF} \text { demagnetization }\left(^{\circ}\right)\end{array}$}} \\
\hline & & \multirow{2}{*}{$\begin{array}{l}\text { Azimuthally } \\
\text { unoriented }\left(^{\circ}\right)\end{array}$} & \multirow{2}{*}{$\begin{array}{c}\text { Geographical } \\
\text { coordinates } \\
\left(0^{\circ}-360^{\circ}\right)\end{array}$} & & & & & \\
\hline & & & & & & & Declination & Inclination \\
\hline $13 \mathrm{H}-2,85$ & 110.75 & 81.4 & 162.3 & -1.9 & 8.6 & $15-35$ & 89.3 & 12.8 \\
\hline $13 \mathrm{H}-4,85$ & 113.75 & NA & NA & NA & NA & NA & 100.5 & 10.6 \\
\hline $13 \mathrm{H}-5,85$ & 115.25 & 96.5 & 177.4 & -6.4 & 12.5 & $15-50$ & 102.9 & 18.2 \\
\hline $13 \mathrm{H}-6,85$ & 116.75 & 110.8 & 191.7 & -2.3 & 9.5 & $10-30$ & 112.8 & 14.9 \\
\hline $13 \mathrm{H}-7,75$ & 118.15 & 288.1 & 9.1 & 2.5 & 6.4 & $10-30$ & & \\
\hline $14 \mathrm{H}-2,85$ & 120.25 & 259.4 & 160.4 & 10.3 & 11.8 & $10-50$ & 276.9 & 15.4 \\
\hline $14 \mathrm{H}-4,85$ & 123.25 & 256.3 & 157.3 & 5.3 & 8.8 & $10-35$ & 271.6 & 8.2 \\
\hline $14 \mathrm{H}-5,85$ & 124.75 & 94.9 & 356.0 & 4.4 & 6.5 & $25-50$ & 95.7 & 10.3 \\
\hline $14 \mathrm{H}-6,20$ & 125.60 & 118.6 & 19.7 & -2.5 & 11.0 & $10-40$ & 115.0 & -2.4 \\
\hline $15 X-1,115$ & 127.05 & NA & NA & NA & NA & NA & 238.8 & 5.7 \\
\hline $15 X-4,85$ & 131.25 & 204.1 & NA & 2.0 & 12.4 & $5-60$ & 204.2 & 39.2 \\
\hline $15 X-5,50$ & 132.40 & NA & NA & NA & NA & NA & 113.70 & 23.20 \\
\hline $16 X-1,85$ & 136.35 & 82.5 & NA & 18.0 & 6.3 & $15-40$ & & \\
\hline
\end{tabular}

Notes: $\mathrm{MAD}=$ maximum angular deviation. $\mathrm{NA}=$ not applicable . 
Table T23. Mean paleomagnetic direction for each core, Site U1332. (See table notes.)

\begin{tabular}{|c|c|c|c|c|}
\hline Core & $\begin{array}{c}\text { Inclination } \\
\left(^{\circ}\right)\end{array}$ & $\begin{array}{l}\text { Declination } \\
\left(^{\circ}\right)\end{array}$ & N & $\begin{array}{c}\alpha 95 \\
\left(^{\circ}\right)\end{array}$ \\
\hline \multicolumn{5}{|c|}{ 320-U1332A- } \\
\hline $1 \mathrm{H}$ & -6.6 & 352.1 & 47 & 4.4 \\
\hline $2 \mathrm{H}$ & -76.1 & 28.0 & 170 & 8.4 \\
\hline $3 \mathrm{H}$ & 3.4 & 156.3 & 162 & 4.7 \\
\hline $4 \mathrm{H}$ & 3.7 & 86.7 & 174 & 3.0 \\
\hline $5 \mathrm{H}$ & -4.7 & 345.9 & 177 & 2.6 \\
\hline $6 \mathrm{H}$ & 7.6 & 192.5 & 164 & 2.1 \\
\hline $7 \mathrm{H}$ & -2.3 & 261.1 & 175 & 4.0 \\
\hline $8 \mathrm{H}$ & 8.6 & 162.3 & 171 & 2.9 \\
\hline $9 \mathrm{H}$ & 3.3 & 104.5 & 176 & 1.4 \\
\hline $10 \mathrm{H}$ & 4.9 & 121.5 & 162 & 1.5 \\
\hline $11 \mathrm{H}$ & 5.7 & 263.3 & 132 & 2.0 \\
\hline $12 \mathrm{H}$ & 3.2 & 293.1 & 143 & 1.5 \\
\hline $13 \mathrm{H}$ & -14.8 & 279.0 & 175 & 2.2 \\
\hline $14 \mathrm{H}$ & -11.6 & 99.0 & 118 & 2.2 \\
\hline \multicolumn{5}{|c|}{ 320-U1332B- } \\
\hline $1 \mathrm{H}$ & 6.9 & 340.9 & 32 & 4.4 \\
\hline $2 \mathrm{H}$ & 30.0 & 101.8 & 170 & 6.9 \\
\hline $3 \mathrm{H}$ & 5.9 & 68.1 & 107 & 4.0 \\
\hline $4 \mathrm{H}$ & 6.0 & 68.6 & 147 & 3.0 \\
\hline $5 \mathrm{H}$ & 12.4 & 219.9 & 127 & 3.0 \\
\hline $6 \mathrm{H}$ & 13.6 & 194.1 & 114 & 3.2 \\
\hline $7 \mathrm{H}$ & -5.9 & 105.0 & 174 & 2.9 \\
\hline $8 \mathrm{H}$ & 7.9 & 188.8 & 132 & 2.8 \\
\hline $9 \mathrm{H}$ & 3.6 & 120.6 & 170 & 1.8 \\
\hline $10 \mathrm{H}$ & 7.4 & 57.9 & 148 & 2.8 \\
\hline $11 \mathrm{H}$ & 4.6 & 18.7 & 99 & 3.8 \\
\hline $12 \mathrm{H}$ & 10.4 & 238.2 & 156 & 2.4 \\
\hline $13 \mathrm{H}$ & -3.2 & 152.1 & 161 & 1.8 \\
\hline \multicolumn{5}{|c|}{ 320-U1332C- } \\
\hline $1 \mathrm{H}$ & 21.9 & 142.9 & 151 & 15.6 \\
\hline $2 \mathrm{H}$ & 17.4 & 5.8 & 151 & 5.0 \\
\hline $3 \mathrm{H}$ & -1.7 & 125.7 & 145 & 3.6 \\
\hline $4 \mathrm{H}$ & 9.1 & 179.8 & 172 & 2.7 \\
\hline $5 \mathrm{H}$ & 3.5 & 215.4 & 169 & 1.4 \\
\hline $6 \mathrm{H}$ & 5.4 & 240.2 & 85 & 2.2 \\
\hline $7 \mathrm{H}$ & -0.1 & 335.5 & 172 & 2.5 \\
\hline $8 \mathrm{H}$ & 5.8 & 120.6 & 134 & 2.5 \\
\hline $9 \mathrm{H}$ & 6.4 & 219.8 & 165 & 2.4 \\
\hline $11 \mathrm{H}$ & 2.2 & 82.4 & 148 & 1.4 \\
\hline $12 \mathrm{H}$ & 3.0 & 92.8 & 155 & 1.4 \\
\hline $13 \mathrm{H}$ & -8.4 & 25.2 & 148 & 2.0 \\
\hline
\end{tabular}

Notes: Mean paleomagnetic directions and statistics calculated using Bingham statistics for each core. Inclination = mean paleomagnetic inclination from stable polarity intervals in core, declination = mean paleomagnetic declination from stable polarity intervals in core. By subtracting this value from observed paleomagnetic declinations measured along core, core can be approximately reoriented back into geographic coordinates. After reorientation, normal polarity intervals will have $\sim 0^{\circ}$ declination and reversed polarity intervals will have $\sim 180^{\circ}$ declination. $N=$ number of paleomagnetic observations used in calculating mean, $\alpha 95=95 \%$ confidence angle for mean direction. 
Table T24. Magnetic susceptibility of discrete samples, Hole U1332A. (See table notes.) (Continued on next page.)

\begin{tabular}{|c|c|c|c|c|c|c|c|c|c|c|}
\hline \multirow[b]{2}{*}{$\begin{array}{l}\text { Core, } \\
\text { section }\end{array}$} & \multirow[b]{2}{*}{$\begin{array}{l}\text { Depth } \\
\text { CSF }(m)\end{array}$} & \multirow[b]{2}{*}{$\begin{array}{l}\text { LIMS } \\
\text { ID }\end{array}$} & \multirow[b]{2}{*}{$\begin{array}{l}\text { Susceptibility } \\
\text { (SI) }\end{array}$} & \multirow[b]{2}{*}{$\begin{array}{l}\text { Total mass } \\
\quad(\mathrm{g})\end{array}$} & \multirow[b]{2}{*}{$\begin{array}{l}\text { Bulk } \\
\text { density } \\
\left(\mathrm{g} / \mathrm{cm}^{3}\right)\end{array}$} & \multirow[b]{2}{*}{$\begin{array}{l}\text { Volume } \\
\left(\mathrm{cm}^{3}\right)\end{array}$} & \multicolumn{3}{|c|}{ Susceptibility } & \multirow[b]{2}{*}{ Scale factor } \\
\hline & & & & & & & $\begin{array}{l}\text { Volume } \\
\text { normalized } \\
\text { (SI) }\end{array}$ & $\begin{array}{c}\text { Mass } \\
\text { normalized } \\
\left(\mathrm{m}^{3} / \mathrm{kg}\right)\end{array}$ & $\begin{array}{l}\text { Whole core } \\
\text { (raw values) }\end{array}$ & \\
\hline \multicolumn{11}{|c|}{ 320-U1332A- } \\
\hline $1 \mathrm{H}-1$ & 1.14 & CUBE582661 & $1.370 \mathrm{E}-04$ & 10.51 & 1.25 & 4.75 & $2.021 \mathrm{E}-04$ & $9.125 \mathrm{E}-08$ & 28.2 & $7.166 \mathrm{E}-06$ \\
\hline $1 \mathrm{H}-2$ & 2.37 & CUBE582671 & $5.981 \mathrm{E}-05$ & 9.50 & 1.24 & 3.97 & $1.054 \mathrm{E}-04$ & 4.407E-08 & 19.0 & $5.549 \mathrm{E}-06$ \\
\hline $1 \mathrm{H}-3$ & 3.43 & CUBE582681 & $1.119 \mathrm{E}-04$ & 11.48 & 1.25 & 5.53 & 1.417E-04 & $6.823 \mathrm{E}-08$ & 17.7 & 8.005E-06 \\
\hline $2 \mathrm{H}-1$ & 4.73 & CUBE583611 & 1.495E-04 & 10.97 & 1.25 & 5.09 & $2.058 \mathrm{E}-04$ & $9.540 \mathrm{E}-08$ & 23.3 & $8.831 \mathrm{E}-06$ \\
\hline $2 \mathrm{H}-2$ & 6.27 & CUBE583621 & 1.782E-04 & 12.46 & 2.25 & 3.49 & $3.574 \mathrm{E}-04$ & $1.001 \mathrm{E}-07$ & 24.0 & $1.489 \mathrm{E}-05$ \\
\hline $2 \mathrm{H}-4$ & 9.24 & CUBE583631 & $2.792 \mathrm{E}-04$ & 12.63 & 1.27 & 6.33 & $3.088 \mathrm{E}-04$ & $1.547 \mathrm{E}-07$ & 42.0 & $7.352 \mathrm{E}-06$ \\
\hline $2 \mathrm{H}-5$ & 10.77 & CUBE583651 & $2.393 \mathrm{E}-04$ & 12.60 & 1.33 & 6.01 & $2.786 \mathrm{E}-04$ & $1.329 \mathrm{E}-07$ & 36.3 & 7.676E-06 \\
\hline $2 \mathrm{H}-6$ & 12.24 & CUBE583671 & $2.382 \mathrm{E}-04$ & 7.69 & 1.32 & 2.36 & $7.078 \mathrm{E}-04$ & $2.168 \mathrm{E}-07$ & 81.4 & 8.695E-06 \\
\hline $3 \mathrm{H}-1$ & 14.34 & CUBE584901 & $2.533 \mathrm{E}-04$ & 11.71 & 1.20 & 5.96 & 2.977E-04 & $1.514 \mathrm{E}-07$ & 37.5 & $7.938 \mathrm{E}-06$ \\
\hline $3 \mathrm{H}-2$ & 15.77 & CUBE584911 & $2.256 \mathrm{E}-04$ & 12.07 & 1.16 & 6.42 & $2.458 \mathrm{E}-04$ & $1.308 \mathrm{E}-07$ & 31.3 & $7.854 \mathrm{E}-06$ \\
\hline $3 \mathrm{H}-3$ & 17.24 & CUBE584921 & $1.623 \mathrm{E}-04$ & 12.06 & 1.23 & 6.09 & $1.865 \mathrm{E}-04$ & $9.420 \mathrm{E}-08$ & 27.0 & $6.908 \mathrm{E}-06$ \\
\hline $3 \mathrm{H}-4$ & 18.73 & CUBE584941 & $2.105 \mathrm{E}-04$ & 12.14 & 1.20 & 6.30 & $2.341 \mathrm{E}-04$ & $1.214 \mathrm{E}-07$ & 31.0 & 7.551E-06 \\
\hline $3 \mathrm{H}-5$ & 20.27 & CUBE584961 & $1.781 \mathrm{E}-04$ & 11.59 & 1.20 & 5.83 & $2.138 \mathrm{E}-04$ & $1.076 \mathrm{E}-07$ & 29.4 & $7.272 \mathrm{E}-06$ \\
\hline $3 \mathrm{H}-6$ & 21.73 & CUBE584981 & $1.810 \mathrm{E}-04$ & 11.89 & 1.22 & 5.99 & $2.116 \mathrm{E}-04$ & $1.066 \mathrm{E}-07$ & 30.0 & 7.054E-06 \\
\hline $3 \mathrm{H}-7$ & 23.03 & CUBE585001 & $6.580 \mathrm{E}-05$ & 11.19 & 1.16 & 5.67 & $8.119 \mathrm{E}-05$ & $4.116 \mathrm{E}-08$ & 30.3 & $2.680 \mathrm{E}-06$ \\
\hline $4 \mathrm{H}-1$ & 23.74 & CUBE586061 & 1.490E-04 & 11.45 & 1.22 & 5.61 & $1.859 \mathrm{E}-04$ & $9.109 \mathrm{E}-08$ & 25.0 & $7.434 \mathrm{E}-06$ \\
\hline $4 \mathrm{H}-2$ & 25.28 & CUBE586071 & $2.111 \mathrm{E}-04$ & 12.60 & 1.28 & 6.27 & $2.358 \mathrm{E}-04$ & $1.173 \mathrm{E}-07$ & 30.4 & $7.758 \mathrm{E}-06$ \\
\hline $4 \mathrm{H}-3$ & 26.73 & CUBE586081 & $1.984 \mathrm{E}-04$ & 12.34 & 1.25 & 6.20 & $2.239 \mathrm{E}-04$ & $1.125 \mathrm{E}-07$ & 27.4 & $8.171 \mathrm{E}-06$ \\
\hline $4 \mathrm{H}-4$ & 28.23 & CUBE586091 & $2.150 \mathrm{E}-04$ & 12.25 & 1.24 & 6.16 & $2.445 \mathrm{E}-04$ & $1.229 \mathrm{E}-07$ & 31.0 & 7.887E-06 \\
\hline $4 \mathrm{H}-5$ & 29.77 & CUBE586101 & $2.115 \mathrm{E}-04$ & 11.92 & 1.21 & 6.04 & $2.451 \mathrm{E}-04$ & $1.242 \mathrm{E}-07$ & 31.3 & $7.830 \mathrm{E}-06$ \\
\hline $4 \mathrm{H}-6$ & 31.24 & CUBE586111 & $1.485 \mathrm{E}-04$ & 12.84 & 1.30 & 6.37 & $1.632 \mathrm{E}-04$ & 8.096E-08 & 23.0 & 7.096E-06 \\
\hline $4 \mathrm{H}-7$ & 32.48 & CUBE586121 & 1.137E-04 & 12.91 & 1.34 & 6.20 & $1.283 \mathrm{E}-04$ & $6.165 \mathrm{E}-08$ & 18.0 & $7.129 \mathrm{E}-06$ \\
\hline $5 \mathrm{H}-1$ & 33.24 & CUBE587081 & $1.186 \mathrm{E}-04$ & 14.38 & 1.58 & 6.21 & $1.336 \mathrm{E}-04$ & $5.773 \mathrm{E}-08$ & 15.2 & $8.789 \mathrm{E}-06$ \\
\hline $5 \mathrm{H}-2$ & 34.77 & CUBE587101 & $6.177 \mathrm{E}-05$ & 12.43 & 1.58 & 4.98 & $8.689 \mathrm{E}-05$ & $3.479 \mathrm{E}-08$ & 10.3 & $8.436 \mathrm{E}-06$ \\
\hline $5 \mathrm{H}-3$ & 36.23 & CUBE587111 & $4.914 \mathrm{E}-05$ & 15.08 & 1.59 & 6.61 & $5.202 \mathrm{E}-05$ & $2.281 \mathrm{E}-08$ & 7.0 & $7.431 \mathrm{E}-06$ \\
\hline $5 \mathrm{H}-4$ & 37.73 & CUBE587121 & $1.368 \mathrm{E}-04$ & 13.97 & 1.52 & 6.17 & $1.552 \mathrm{E}-04$ & $6.855 \mathrm{E}-08$ & 14.7 & $1.056 \mathrm{E}-05$ \\
\hline $5 \mathrm{H}-5$ & 39.26 & CUBE587131 & $1.028 \mathrm{E}-04$ & 13.90 & 1.56 & 5.96 & $1.208 \mathrm{E}-04$ & $5.177 \mathrm{E}-08$ & 13.3 & $9.080 \mathrm{E}-06$ \\
\hline $5 \mathrm{H}-6$ & 40.73 & CUBE587141 & $3.744 \mathrm{E}-05$ & 10.82 & 1.57 & 3.96 & $6.624 \mathrm{E}-05$ & $2.422 \mathrm{E}-08$ & 8.0 & $8.280 \mathrm{E}-06$ \\
\hline $5 \mathrm{H}-7$ & 42.22 & CUBE587091 & $1.685 \mathrm{E}-05$ & 15.97 & 1.65 & 6.91 & $1.707 \mathrm{E}-05$ & $7.386 \mathrm{E}-09$ & 3.1 & $5.508 \mathrm{E}-06$ \\
\hline $6 \mathrm{H}-1$ & 43.03 & CUBE587781 & 3.609E-05 & 14.30 & 1.67 & 5.81 & $4.346 \mathrm{E}-05$ & $1.767 \mathrm{E}-08$ & 5.0 & $8.692 \mathrm{E}-06$ \\
\hline $6 \mathrm{H}-2$ & 44.24 & CUBE587791 & 3.019E-05 & 14.87 & 1.68 & 6.13 & $3.448 \mathrm{E}-05$ & $1.421 \mathrm{E}-08$ & 4.1 & $8.410 \mathrm{E}-06$ \\
\hline $6 \mathrm{H}-3$ & 45.76 & CUBE587811 & $6.392 \mathrm{E}-05$ & 14.38 & 1.26 & 7.79 & $5.742 \mathrm{E}-05$ & $3.112 \mathrm{E}-08$ & 8.5 & $6.755 E-06$ \\
\hline $6 \mathrm{H}-4$ & 47.23 & CUBE587821 & $2.600 \mathrm{E}-05$ & 14.60 & 1.66 & 6.02 & $3.022 \mathrm{E}-05$ & $1.247 \mathrm{E}-08$ & 2.0 & $1.511 \mathrm{E}-05$ \\
\hline $6 \mathrm{H}-5$ & 48.76 & CUBE587831 & $5.422 \mathrm{E}-05$ & 15.51 & 1.73 & 6.32 & $6.004 \mathrm{E}-05$ & $2.447 \mathrm{E}-08$ & 4.7 & 1.277E-05 \\
\hline $6 \mathrm{H}-6$ & 50.25 & CUBE587841 & $5.287 \mathrm{E}-05$ & 14.15 & 1.66 & 5.76 & $6.424 \mathrm{E}-05$ & $2.615 \mathrm{E}-08$ & 6.2 & $1.036 \mathrm{E}-05$ \\
\hline $6 \mathrm{H}-7$ & 51.34 & CUBE587801 & $7.530 \mathrm{E}-05$ & 14.15 & 1.64 & 5.84 & $9.028 \mathrm{E}-05$ & $3.725 \mathrm{E}-08$ & 10.3 & $8.765 E-06$ \\
\hline $7 \mathrm{H}-1$ & 52.24 & CUBE588081 & $1.151 \mathrm{E}-04$ & 12.18 & 1.47 & 5.16 & $1.561 \mathrm{E}-04$ & $6.615 \mathrm{E}-08$ & 19.8 & 7.883E-06 \\
\hline $7 \mathrm{H}-2$ & 53.73 & CUBE588101 & $5.998 \mathrm{E}-05$ & 14.10 & 1.56 & 6.11 & $6.871 \mathrm{E}-05$ & $2.978 \mathrm{E}-08$ & 12.0 & $5.726 \mathrm{E}-06$ \\
\hline $7 \mathrm{H}-3$ & 55.23 & CUBE588111 & 3.176E-05 & 13.19 & 1.67 & 5.15 & $4.313 \mathrm{E}-05$ & $1.686 \mathrm{E}-08$ & 7.2 & $5.990 \mathrm{E}-06$ \\
\hline $7 \mathrm{H}-4$ & 56.74 & CUBE588121 & $2.345 \mathrm{E}-05$ & 14.85 & 1.67 & 6.14 & $2.672 \mathrm{E}-05$ & $1.105 \mathrm{E}-08$ & 5.0 & $5.345 \mathrm{E}-06$ \\
\hline $7 \mathrm{H}-5$ & 58.24 & CUBE588131 & $3.774 \mathrm{E}-05$ & 15.17 & 1.65 & 6.40 & $4.128 \mathrm{E}-05$ & $1.741 \mathrm{E}-08$ & 5.9 & $6.997 \mathrm{E}-06$ \\
\hline $7 \mathrm{H}-6$ & 59.73 & CUBE588141 & $4.253 \mathrm{E}-05$ & 14.80 & 1.66 & 6.14 & 4.847E-05 & $2.012 \mathrm{E}-08$ & 6.4 & $7.574 \mathrm{E}-06$ \\
\hline $7 \mathrm{H}-7$ & 60.83 & CUBE588091 & $4.894 \mathrm{E}-05$ & 14.62 & 1.62 & 6.21 & 5.517E-05 & $2.343 \mathrm{E}-08$ & 7.0 & $7.882 \mathrm{E}-06$ \\
\hline $8 \mathrm{H}-2$ & 63.23 & CUBE588401 & 4.564E-05 & 13.80 & 1.46 & 6.33 & $5.048 \mathrm{E}-05$ & $2.315 \mathrm{E}-08$ & 9.2 & $5.487 \mathrm{E}-06$ \\
\hline $8 \mathrm{H}-3$ & 64.76 & CUBE588421 & $5.316 \mathrm{E}-05$ & 14.13 & 1.52 & 6.28 & $5.926 \mathrm{E}-05$ & $2.633 \mathrm{E}-08$ & 11.7 & $5.065 \mathrm{E}-06$ \\
\hline $8 \mathrm{H}-4$ & 66.23 & CUBE588431 & $7.562 \mathrm{E}-05$ & 14.10 & 1.51 & 6.30 & 8.407E-05 & $3.754 \mathrm{E}-08$ & 14.8 & $5.680 \mathrm{E}-06$ \\
\hline $8 \mathrm{H}-5$ & 67.73 & CUBE588441 & $1.173 \mathrm{E}-04$ & 13.70 & 1.42 & 6.41 & $1.281 \mathrm{E}-04$ & $5.993 \mathrm{E}-08$ & 21.4 & $5.986 \mathrm{E}-06$ \\
\hline $8 \mathrm{H}-6$ & 69.24 & CUBE588451 & $6.113 \mathrm{E}-05$ & 15.49 & 1.66 & 6.58 & $6.502 \mathrm{E}-05$ & $2.762 \mathrm{E}-08$ & 12.3 & $5.286 \mathrm{E}-06$ \\
\hline $8 \mathrm{H}-7$ & 70.33 & CUBE588411 & $3.856 \mathrm{E}-05$ & 15.21 & 1.72 & 6.19 & $4.360 \mathrm{E}-05$ & $1.775 \mathrm{E}-08$ & 9.5 & $4.589 \mathrm{E}-06$ \\
\hline $9 \mathrm{H}-1$ & 71.24 & CUBE588941 & $6.490 \mathrm{E}-05$ & 13.55 & 1.52 & 5.88 & $7.729 \mathrm{E}-05$ & $3.353 \mathrm{E}-08$ & 11.0 & $7.026 \mathrm{E}-06$ \\
\hline $9 \mathrm{H}-2$ & 72.74 & CUBE588951 & $1.060 \mathrm{E}-04$ & 12.64 & 1.47 & 5.47 & 1.357E-04 & $5.870 \mathrm{E}-08$ & 15.0 & $9.048 \mathrm{E}-06$ \\
\hline $9 \mathrm{H}-3$ & 74.27 & CUBE588961 & 4.696E-05 & 15.17 & 1.47 & 7.21 & $4.562 \mathrm{E}-05$ & $2.167 \mathrm{E}-08$ & 5.7 & 8.003E-06 \\
\hline $9 \mathrm{H}-4$ & 76.24 & CUBE588971 & $3.174 \mathrm{E}-04$ & 12.31 & 1.28 & 6.05 & $3.670 \mathrm{E}-04$ & $1.805 \mathrm{E}-07$ & 44.0 & $8.342 \mathrm{E}-06$ \\
\hline $9 \mathrm{H}-5$ & 77.23 & CUBE588981 & $1.996 \mathrm{E}-04$ & 12.45 & 1.24 & 6.36 & $2.198 \mathrm{E}-04$ & $1.122 \mathrm{E}-07$ & 26.0 & $8.453 \mathrm{E}-06$ \\
\hline $9 \mathrm{H}-6$ & 78.73 & CUBE588991 & $2.504 \mathrm{E}-04$ & 12.22 & 1.26 & 6.06 & $2.893 \mathrm{E}-04$ & $1.434 \mathrm{E}-07$ & 33.3 & $8.688 \mathrm{E}-06$ \\
\hline $9 \mathrm{H}-7$ & 79.83 & CUBE589001 & $2.811 \mathrm{E}-04$ & 12.08 & 1.25 & 5.97 & 3.295E-04 & $1.629 \mathrm{E}-07$ & 40.0 & $8.238 \mathrm{E}-06$ \\
\hline $10 \mathrm{H}-1$ & 80.84 & CUBE589271 & $2.333 \mathrm{E}-04$ & 11.80 & 1.23 & 5.85 & $2.794 \mathrm{E}-04$ & $1.384 \mathrm{E}-07$ & 34.0 & 8.217E-06 \\
\hline $10 \mathrm{H}-2$ & 82.23 & CUBE589281 & $1.814 \mathrm{E}-04$ & 12.04 & 1.23 & 6.06 & $2.095 \mathrm{E}-04$ & $1.055 \mathrm{E}-07$ & 26.0 & 8.059E-06 \\
\hline $10 \mathrm{H}-3$ & 83.76 & CUBE589291 & $1.876 \mathrm{E}-04$ & 13.15 & 1.29 & 6.64 & $1.978 \mathrm{E}-04$ & $9.986 \mathrm{E}-08$ & 25.7 & 7.696E-06 \\
\hline $10 \mathrm{H}-4$ & 85.23 & CUBE589301 & $2.010 \mathrm{E}-04$ & 12.33 & 1.28 & 6.07 & $2.318 \mathrm{E}-04$ & $1.141 \mathrm{E}-07$ & 29.0 & 7.994E-06 \\
\hline $10 \mathrm{H}-5$ & 86.73 & CUBE589311 & $1.629 \mathrm{E}-04$ & 12.04 & 1.23 & 6.06 & $1.882 \mathrm{E}-04$ & $9.471 \mathrm{E}-08$ & 25.0 & 7.527E-06 \\
\hline $10 \mathrm{H}-6$ & 88.23 & CUBE589321 & $1.481 \mathrm{E}-04$ & 11.99 & 1.23 & 6.00 & $1.729 \mathrm{E}-04$ & $8.646 \mathrm{E}-08$ & 18.7 & $9.247 \mathrm{E}-06$ \\
\hline $10 \mathrm{H}-7$ & 89.38 & CUBE589331 & $1.464 \mathrm{E}-04$ & 11.65 & 1.25 & 5.66 & $1.811 \mathrm{E}-04$ & 8.797E-08 & 23.0 & $7.872 \mathrm{E}-06$ \\
\hline $11 \mathrm{H}-2$ & 9173 & UBE589561 & $.824 \mathrm{E}-04$ & 1166 & 121 & 5.84 & $2186 \mathrm{~F}-04$ & $1.095 \mathrm{E}-07$ & 267 & $8174 \mathrm{~F}-06$ \\
\hline
\end{tabular}


Table T24 (continued).

\begin{tabular}{|c|c|c|c|c|c|c|c|c|c|c|}
\hline \multirow[b]{2}{*}{$\begin{array}{l}\text { Core, } \\
\text { section }\end{array}$} & \multirow[b]{2}{*}{$\begin{array}{l}\text { Depth } \\
\text { CSF }(m)\end{array}$} & \multirow[b]{2}{*}{$\begin{array}{l}\text { LIMS } \\
\text { ID }\end{array}$} & \multirow[b]{2}{*}{$\begin{array}{l}\text { Susceptibility } \\
\text { (SI) }\end{array}$} & \multirow[b]{2}{*}{$\begin{array}{l}\text { Total mass } \\
(\mathrm{g})\end{array}$} & \multirow[b]{2}{*}{$\begin{array}{c}\text { Bulk } \\
\text { density } \\
\left(\mathrm{g} / \mathrm{cm}^{3}\right)\end{array}$} & \multirow[b]{2}{*}{$\begin{array}{l}\text { Volume } \\
\left(\mathrm{cm}^{3}\right)\end{array}$} & \multicolumn{3}{|c|}{ Susceptibility } & \multirow[b]{2}{*}{ Scale factor } \\
\hline & & & & & & & $\begin{array}{c}\text { Volume } \\
\text { normalized } \\
\text { (SI) }\end{array}$ & $\begin{array}{c}\text { Mass } \\
\text { normalized } \\
\left(\mathrm{m}^{3} / \mathrm{kg}\right)\end{array}$ & $\begin{array}{l}\text { Whole core } \\
\text { (raw values) }\end{array}$ & \\
\hline $11 \mathrm{H}-3$ & 93.26 & CUBE589571 & 1.819E-04 & 11.92 & 1.23 & 5.98 & $2.130 \mathrm{E}-04$ & $1.068 \mathrm{E}-07$ & 27.0 & 7.890E-06 \\
\hline $11 \mathrm{H}-4$ & 94.73 & CUBE589581 & $2.270 \mathrm{E}-04$ & 12.23 & 1.24 & 6.17 & $2.576 \mathrm{E}-04$ & $1.299 \mathrm{E}-07$ & 33.7 & 7.643E-06 \\
\hline $11 \mathrm{H}-5$ & 96.24 & CUBE589591 & $1.950 \mathrm{E}-04$ & 12.73 & 1.26 & 6.48 & $2.105 \mathrm{E}-04$ & $1.072 \mathrm{E}-07$ & 32.2 & 6.537E-06 \\
\hline $11 \mathrm{H}-6$ & 97.73 & CUBE589601 & $1.082 \mathrm{E}-04$ & 12.16 & 1.34 & 5.66 & $1.338 \mathrm{E}-04$ & $6.229 \mathrm{E}-08$ & 25.8 & $5.186 \mathrm{E}-06$ \\
\hline $12 \mathrm{H}-7$ & 101.24 & CUBE589951 & $1.334 \mathrm{E}-04$ & 12.43 & 1.23 & 6.40 & $1.459 \mathrm{E}-04$ & $7.512 \mathrm{E}-08$ & 18.0 & $8.108 \mathrm{E}-06$ \\
\hline $12 \mathrm{H}-3$ & 102.76 & CUBE589981 & $1.371 \mathrm{E}-04$ & 12.66 & 1.26 & 6.38 & $1.504 \mathrm{E}-04$ & $7.581 \mathrm{E}-08$ & 17.3 & $8.691 \mathrm{E}-06$ \\
\hline $12-\mathrm{H} 4$ & 104.24 & CUBE589991 & $1.163 \mathrm{E}-04$ & 12.10 & 1.23 & 6.09 & $1.337 \mathrm{E}-04$ & $6.728 \mathrm{E}-08$ & 14.8 & $9.034 \mathrm{E}-06$ \\
\hline $12 \mathrm{H}-5$ & 105.80 & CUBE590001 & $6.721 \mathrm{E}-05$ & 11.87 & 1.22 & 5.96 & 7.899E-05 & $3.964 \mathrm{E}-08$ & 7.7 & $1.026 \mathrm{E}-05$ \\
\hline $12 \mathrm{H}-6$ & 107.23 & CUBE589961 & $8.106 \mathrm{E}-05$ & 11.98 & 1.23 & 6.01 & $9.439 \mathrm{E}-05$ & $4.736 \mathrm{E}-08$ & 7.7 & $1.226 \mathrm{E}-05$ \\
\hline $12 \mathrm{H}-7$ & 108.18 & CUBE589971 & $1.138 \mathrm{E}-04$ & 12.49 & 1.25 & 6.30 & $1.265 \mathrm{E}-04$ & $6.378 \mathrm{E}-08$ & 10.8 & $1.171 \mathrm{E}-05$ \\
\hline $13 \mathrm{H}-1$ & 109.24 & CUBE590231 & $1.193 \mathrm{E}-04$ & 12.22 & 1.23 & 6.21 & $1.344 \mathrm{E}-04$ & $6.834 \mathrm{E}-08$ & 18.0 & $7.469 \mathrm{E}-06$ \\
\hline $13 \mathrm{H}-2$ & 110.73 & CUBE590251 & $1.129 \mathrm{E}-04$ & 11.73 & 1.26 & 5.65 & $1.398 \mathrm{E}-04$ & 6.737E-08 & 18.2 & $7.683 \mathrm{E}-06$ \\
\hline $13 \mathrm{H}-3$ & 112.26 & CUBE590261 & $1.331 \mathrm{E}-04$ & 13.65 & 1.23 & 7.37 & $1.264 \mathrm{E}-04$ & $6.826 \mathrm{E}-08$ & 19.0 & $6.653 \mathrm{E}-06$ \\
\hline $13 \mathrm{H}-4$ & 113.73 & CUBE590271 & $1.042 \mathrm{E}-04$ & 12.78 & 1.47 & 5.58 & 1.307E-04 & 5.707E-08 & 16.3 & 8.017E-06 \\
\hline $13 \mathrm{H}-5$ & 115.23 & CUBE590281 & $1.060 \mathrm{E}-04$ & 11.97 & 1.38 & 5.36 & $1.385 \mathrm{E}-04$ & $6.199 \mathrm{E}-08$ & 17.9 & 7.737E-06 \\
\hline $13 \mathrm{H}-6$ & 116.73 & CUBE590291 & 1.337E-04 & 12.48 & 1.34 & 5.91 & $1.584 \mathrm{E}-04$ & 7.499E-08 & 18.4 & 8.609E-06 \\
\hline $13 \mathrm{H}-7$ & 118.12 & CUBE590241 & $1.101 \mathrm{E}-04$ & 12.63 & 1.40 & 5.75 & $1.341 \mathrm{E}-04$ & $6.102 \mathrm{E}-08$ & 12.5 & $1.073 \mathrm{E}-05$ \\
\hline $14 \mathrm{H}-2$ & 120.23 & CUBE590651 & $1.976 \mathrm{E}-04$ & 12.56 & 1.32 & 6.03 & $2.295 \mathrm{E}-04$ & $1.101 \mathrm{E}-07$ & 25.4 & $9.035 \mathrm{E}-06$ \\
\hline $14 \mathrm{H}-3$ & 121.77 & CUBE590671 & $1.791 \mathrm{E}-04$ & 12.92 & 1.23 & 6.76 & $1.855 \mathrm{E}-04$ & $9.704 \mathrm{E}-08$ & 24.8 & $7.479 \mathrm{E}-06$ \\
\hline $14 \mathrm{H}-4$ & 123.23 & CUBE590681 & $1.265 \mathrm{E}-04$ & 11.21 & 1.29 & 5.12 & $1.730 \mathrm{E}-04$ & $7.899 \mathrm{E}-08$ & 21.9 & $7.900 \mathrm{E}-06$ \\
\hline $14 \mathrm{H}-5$ & 124.73 & CUBE590691 & $1.436 \mathrm{E}-04$ & 11.96 & 1.26 & 5.85 & $1.718 \mathrm{E}-04$ & $8.405 \mathrm{E}-08$ & 22.0 & 7.807E-06 \\
\hline $14 \mathrm{H}-6$ & 125.59 & CUBE590661 & $1.718 \mathrm{E}-04$ & 12.36 & 1.32 & 5.90 & $2.039 \mathrm{E}-04$ & $9.730 \mathrm{E}-08$ & 25.0 & $8.156 \mathrm{E}-06$ \\
\hline $15 X-1$ & 127.04 & CUBE590791 & $8.267 \mathrm{E}-05$ & 12.49 & 1.28 & 6.16 & $9.401 \mathrm{E}-05$ & 4.633E-08 & 15.9 & $5.912 \mathrm{E}-06$ \\
\hline $15 X-3$ & 129.80 & CUBE590801 & $9.385 \mathrm{E}-05$ & 12.72 & 1.25 & 6.51 & $1.010 \mathrm{E}-04$ & $5.165 \mathrm{E}-08$ & 13.4 & $7.534 \mathrm{E}-06$ \\
\hline $15 X-4$ & 131.23 & CUBE590811 & $8.111 \mathrm{E}-05$ & 12.14 & 1.24 & 6.11 & 9.297E-05 & 4.677E-08 & 10.7 & $8.689 \mathrm{E}-06$ \\
\hline $15 X-5$ & 132.38 & CUBE590821 & $1.131 \mathrm{E}-04$ & 11.99 & 1.24 & 5.95 & $1.330 \mathrm{E}-04$ & $6.603 \mathrm{E}-08$ & 14.3 & $9.302 \mathrm{E}-06$ \\
\hline \multirow[t]{2}{*}{$16 X-1$} & 136.34 & CUBE591041 & $1.475 \mathrm{E}-04$ & 12.47 & 1.31 & 6.00 & $1.721 \mathrm{E}-04$ & $8.280 \mathrm{E}-08$ & 20.1 & $8.561 \mathrm{E}-06$ \\
\hline & & & & & & & & \multicolumn{2}{|c|}{ Mean scale factor: } & $7.96 \mathrm{E}-06$ \\
\hline
\end{tabular}

Notes: Depth = depth to middle of discrete sample measured in meters using the core depth below seafloor, method A (CSF), depth scale. LIMS ID = sample identification within the Laboratory Information Management System (LIMS) database. Susceptibility = volume magnetic susceptibility of discrete sample measured in KappaBridge with volume of cube assumed to be $7 \mathrm{~cm}^{3}$. Mass = mass of sample including mass of plastic cube, which has a mean of $4.5921 \mathrm{~g}$. Bulk density = density from moisture and density (MAD) measurements. When these were not available or were obviously anomalous, we used a density of $1.2 \mathrm{~m}^{3} / \mathrm{kg}$. Volume = volume of sediments, calculated by subtracting mass of plastic cube from total mass and then dividing by bulk density. Volume normalized susceptibility = susceptibility of discrete samples normalized by true sample volume. These are unitless in the SI unit system. Mass normalized susceptibility = susceptibility of discrete samples normalize by mass of sediments in each sample cube. Scale factor = factor whole-core raw susceptibility values would need to be multiplied by to convert them to SI volume normalized susceptibilities. 
Table T25. Magnetostratigraphy, Site U1332. (See table note.) (Continued on next five pages.)

\begin{tabular}{|c|c|c|c|c|c|}
\hline \multirow[b]{2}{*}{ Polarity chron } & \multirow[b]{2}{*}{$\begin{array}{l}\text { Age } \\
(\mathrm{Ma})\end{array}$} & \multicolumn{4}{|c|}{ Hole U1332A } \\
\hline & & $\begin{array}{l}\text { Range } \\
\operatorname{CSF}(\mathrm{m})\end{array}$ & $\begin{array}{l}\text { Best estimate } \\
\text { CSF }(\mathrm{m})\end{array}$ & $\begin{array}{l}\text { Best estimate core, } \\
\text { section, interval }(\mathrm{cm})\end{array}$ & $\begin{array}{l}\text { Measurement } \\
\text { type }\end{array}$ \\
\hline & 0.000 & $0.00-0.00$ & 0.000 & Mudline & Split core \\
\hline $\mathrm{C} 1 \mathrm{n}-\mathrm{C} 1 \mathrm{r} .1 \mathrm{r}$ & 0.781 & $1.25-1.25$ & 1.250 & $1 \mathrm{H}-1,125.0$ & Split core \\
\hline C1r.1r-C1r.1n & 0.988 & $1.80-1.85$ & 1.825 & $1 \mathrm{H}-2,32.5$ & Split core \\
\hline $\mathrm{C} 1 \mathrm{r} .1 \mathrm{n}-\mathrm{C} 1 \mathrm{r} .2 \mathrm{r}$ & 1.072 & $2.00-2.05$ & 2.025 & $1 \mathrm{H}-2,52.5$ & Split core \\
\hline$C 1 r .2 r-C 2 n$ & 1.778 & $5.00-5.30$ & 5.150 & $2 \mathrm{H}-1,125.0$ & Split core \\
\hline $\mathrm{C} 2 \mathrm{n}-\mathrm{C} 2 \mathrm{r} .1 \mathrm{r}$ & 1.945 & $5.60-5.60$ & 5.600 & $2 \mathrm{H}-2,20.0$ & Split core \\
\hline$C 2 r .1 r-C 2 r .1 n$ & 2.128 & $6.40-6.40$ & 6.400 & $2 \mathrm{H}-2,100.0$ & Split core \\
\hline$C 2 r .1 n-C 2 r .2 r$ & 2.148 & $6.45-6.50$ & 6.475 & $2 \mathrm{H}-2,107.5$ & Split core \\
\hline C2r.2r-C2An.1n & 2.581 & $8.25-8.30$ & 8.275 & $2 \mathrm{H}-3,137.5$ & Split core \\
\hline C2An.1n-C2An.1r & 3.032 & $9.35-9.50$ & 9.425 & $2 \mathrm{H}-4,102.5$ & Split core \\
\hline C2An.1r-C2An.2n & 3.116 & $9.70-9.75$ & 9.725 & $2 \mathrm{H}-4,132.5$ & Split core \\
\hline C $2 A n .2 n-C 2 A n .2 r$ & 3.207 & $10.00-10.05$ & 10.025 & $2 \mathrm{H}-5,12.5$ & Split core \\
\hline C2An.2r-C2An.3n & 3.330 & $10.30-10.35$ & 10.325 & $2 \mathrm{H}-5,42.5$ & Split core \\
\hline C2An.3n-C2Ar & 3.596 & $10.95-10.95$ & 10.950 & $2 \mathrm{H}-5,105.0$ & Split core \\
\hline Hiatus & & & & Hiatus & \\
\hline C5En-C5Er & 18.524 & & & Not identified & \\
\hline C5Er-C6n & 18.748 & & & Not identified & \\
\hline $\mathrm{C} 6 \mathrm{n}-\mathrm{C} 6 \mathrm{r}$ & 19.722 & & & Not identified & \\
\hline C6r-C6An.1n & 20.040 & & & Not identified & \\
\hline C6An.1n-C6An.1r & 20.213 & & Above 14.20 & Above $3 \mathrm{H}-1,80.0$ & Split core \\
\hline C6An.1r-C6An.2n & 20.439 & $14.55-14.60$ & 14.575 & $3 \mathrm{H}-1,117.5$ & Split core \\
\hline C6An.2n-C6Ar & 20.709 & $15.30-15.35$ & 15.325 & $3 \mathrm{H}-2,42.5$ & Split core \\
\hline C6Ar-C6AAn & 21.083 & $16.25-16.30$ & 16.275 & $3 \mathrm{H}-2,137.5$ & Split core \\
\hline C6AAn-C6AAr.1r & 21.159 & $16.30-16.50$ & 16.400 & Between Sections $3 \mathrm{H}-2$ and 3 & Split core \\
\hline C6AAr.1r-C6AAr.1n & 21.403 & $17.30-17.35$ & 17.325 & $3 \mathrm{H}-3,92.5$ & Split core \\
\hline C6AAr.1n-C6AAr.2r & 21.483 & $17.50-17.55$ & 17.525 & $3 \mathrm{H}-3,112.5$ & Split core \\
\hline C6AAr.2r-C6AAr.2n & 21.659 & $18.05-18.05$ & 18.050 & $3 \mathrm{H}-4,15.0$ & Split core \\
\hline C6AAr.2n-C6AAr.3r & 21.688 & $18.15-18.20$ & 18.175 & $3 \mathrm{H}-4,27.5$ & Split core \\
\hline C6AAr.3r-C6Bn.1n & 21.767 & $18.40-18.40$ & 18.400 & $3 \mathrm{H}-4,50.0$ & Split core \\
\hline C6Bn.1n-C6Bn.1r & 21.936 & $18.60-18.65$ & 18.625 & $3 \mathrm{H}-4,72.5$ & Split core \\
\hline C6Bn.1r-C6Bn.2n & 21.992 & $19.10-19.30$ & 19.200 & $3 \mathrm{H}-4,130.0$ & Split core \\
\hline $\mathrm{C} 6 \mathrm{Bn} .2 \mathrm{n}-\mathrm{C} 6 \mathrm{Br}$ & 22.268 & 19.70-19.95 & 19.825 & $3 \mathrm{H}-5,42.5$ & Split core \\
\hline $\mathrm{C} 6 \mathrm{Br}-\mathrm{C} 6 \mathrm{Cn} .1 \mathrm{n}$ & 22.564 & $21.50-21.50$ & 21.500 & $3 \mathrm{H}-6,60.0$ & Split core \\
\hline C6Cn.1n-C6Cn.1r & 22.754 & $22.15-22.15$ & 22.150 & $3 \mathrm{H}-6,125.0$ & Split core \\
\hline $\mathrm{C} 6 \mathrm{Cn} .1 \mathrm{r}-\mathrm{C} 6 \mathrm{Cn} .2 \mathrm{n}$ & 22.902 & $22.25-22.25$ & 22.250 & $3 \mathrm{H}-6,135.0$ & Split core \\
\hline C 6 Cn.2n-C 6 Cn.2r & 23.030 & $22.30-22.50$ & 22.400 & Between Sections $3 \mathrm{H}-6$ and 7 & Split core \\
\hline C $6 C n .2 r-C 6 C n .3 n$ & 23.278 & $22.65-22.65$ & 22.650 & $3 \mathrm{H}-7,25.0$ & Split core \\
\hline $\mathrm{C} 6 \mathrm{Cn} \cdot 3 \mathrm{n}-\mathrm{C} 6 \mathrm{Cr}$ & 23.340 & $22.90-22.95$ & 22.925 & $3 \mathrm{H}-7,52.5$ & Split core \\
\hline $\mathrm{C} 6 \mathrm{Cr}-\mathrm{C} 7 \mathrm{n} .1 \mathrm{n}$ & 24.022 & $24.10-24.10$ & 24.100 & $4 \mathrm{H}-1,120.0$ & Split core \\
\hline C7n.1n-C7n.1r & 24.062 & $24.20-24.20$ & 24.200 & $4 \mathrm{H}-1,130.0$ & Split core \\
\hline C7n.1r-C7n.2n & 24.147 & $24.30-24.60$ & 24.450 & Between Sections $4 \mathrm{H}-1$ and 2 & Split core \\
\hline $\mathrm{C} 7 \mathrm{n} \cdot 2 \mathrm{n}-\mathrm{C} 7 \mathrm{r}$ & 24.459 & $25.55-25.60$ & 25.575 & $4 \mathrm{H}-2,117.5$ & Split core \\
\hline C7r-C7An & 24.756 & $26.30-26.50$ & 26.400 & $4 \mathrm{H}-3,50.0$ & Split core \\
\hline C7An-C7Ar & 24.984 & $26.80-26.85$ & 26.825 & $4 \mathrm{H}-3,92.5$ & Split core \\
\hline C7Ar-C8n.1n & 25.110 & $27.30-27.50$ & 27.400 & Between Sections $4 \mathrm{H}-3$ and 4 & Split core \\
\hline C8n.1n-C8n.1r & 25.248 & $27.75-27.80$ & 27.775 & $4 \mathrm{H}-4,37.5$ & Split core \\
\hline C $8 n .1 r-C 8 n .2 n$ & 25.306 & $27.90-27.90$ & 27.900 & $4 \mathrm{H}-4,50.0$ & Split core \\
\hline $\mathrm{C} 8 \mathrm{n} \cdot 2 \mathrm{n}-\mathrm{C} 8 \mathrm{r}$ & 26.032 & $30.15-30.20$ & 30.175 & $4 \mathrm{H}-5,127.5$ & Split core \\
\hline $\mathrm{C} 8 \mathrm{r}-\mathrm{C} 9 \mathrm{n}$ & 26.508 & $31.80-32.00$ & 31.900 & Between Sections $4 \mathrm{H}-6$ and 7 & Split core \\
\hline $\mathrm{C} 9 \mathrm{n}-\mathrm{C} 9 \mathrm{r}$ & 27.412 & $33.80-34.00$ & 33.900 & Between Sections $5 \mathrm{H}-1$ and 2 & Split core \\
\hline C9r-C10n.1n & 27.886 & $35.90-35.90$ & 35.900 & $5 \mathrm{H}-3,50.0$ & Split core \\
\hline C10n.1n-C10n.1r & 28.126 & $36.80-37.00$ & 36.900 & Between Sections $5 \mathrm{H}-3$ and 4 & Split core \\
\hline C10n.1r-C10n.2n & 28.164 & $37.25-37.30$ & 37.275 & $5 \mathrm{H}-4,37.5$ & Split core \\
\hline $\mathrm{C} 10 \mathrm{n} \cdot 2 \mathrm{n}-\mathrm{C} 10 \mathrm{r}$ & 28.318 & $37.70-37.70$ & 37.700 & $5 \mathrm{H}-4,80.0$ & Split core \\
\hline C10r-C11n.1n & 29.166 & $43.30-43.50$ & 43.400 & Between Sections $6 \mathrm{H}-1$ and 2 & Split core \\
\hline C11n.1n-C11n.1r & 29.467 & $45.95-45.95$ & 45.950 & $6 \mathrm{H}-3,105.0$ & Split core \\
\hline $\mathrm{C} 11 \mathrm{n} .1 \mathrm{r}-\mathrm{C} 11 \mathrm{n} .2 \mathrm{n}$ & 29.536 & $46.15-46.20$ & 46.175 & $6 \mathrm{H}-3,127.5$ & Split core \\
\hline $\mathrm{C} 11 \mathrm{n} .2 \mathrm{n}-\mathrm{C} 11 \mathrm{r}$ & 29.957 & $48.25-48.30$ & 48.275 & $6 \mathrm{H}-5,37.5$ & Split core \\
\hline $\mathrm{C} 11 \mathrm{r}-\mathrm{C} 12 \mathrm{n}$ & 30.617 & $51.55-51.60$ & 51.575 & $6 \mathrm{H}-7,67.5$ & Split core \\
\hline $\mathrm{C} 12 \mathrm{n}-\mathrm{C} 12 \mathrm{r}$ & 31.021 & & & Not identified & Split core \\
\hline $\mathrm{C} 12 \mathrm{r}-\mathrm{C} 13 \mathrm{n}$ & 33.232 & $67.65-67.70$ & 67.675 & $8 \mathrm{H}-5,77.5$ & Split core \\
\hline (repeated) & 33.232 & $72.50-72.55$ & 72.525 & $9 \mathrm{H}-2,62.5$ & Split core \\
\hline $\mathrm{C} 13 n-\mathrm{C} 13 \mathrm{r}$ & 33.705 & $75.30-75.35$ & 75.325 & $9 \mathrm{H}-4,42.5$ & Split core \\
\hline $\mathrm{C} 13 \mathrm{r}-\mathrm{C} 15 \mathrm{n}$ & 35.126 & $79.50-79.55$ & 79.525 & $9 \mathrm{H}-7,12.5$ & Split core \\
\hline $\mathrm{C} 15 n-C 15 r$ & 35.254 & & Below 80.15 & Below 9H-7, 75.0 & Split core \\
\hline C15r-C16n.1n & 35.328 & $81.20-81.30$ & 81.250 & $10 \mathrm{H}-1,135.0$ & Split core \\
\hline C16n.1n-C16n.1r & 35.554 & $82.05-82.05$ & 82.050 & $10 \mathrm{H}-2,65.0$ & Split core \\
\hline C16n.1r-C16n.2n & 35.643 & $82.60-82.65$ & 82.625 & $10 \mathrm{H}-2,122.5$ & Split core \\
\hline
\end{tabular}


Table T25 (continued). (Continued on next page.)

\begin{tabular}{|c|c|c|c|c|c|}
\hline \multirow[b]{2}{*}{ Polarity chron } & \multirow[b]{2}{*}{$\begin{array}{l}\text { Age } \\
(\mathrm{Ma})\end{array}$} & \multicolumn{4}{|c|}{ Hole U1332B } \\
\hline & & $\begin{array}{l}\text { Range } \\
\operatorname{CSF}(\mathrm{m})\end{array}$ & $\begin{array}{l}\text { Best estimate } \\
\text { CSF }(m)\end{array}$ & $\begin{array}{l}\text { Best estimate core, } \\
\text { section, interval }(\mathrm{cm})\end{array}$ & $\begin{array}{l}\text { Measurement } \\
\text { type }\end{array}$ \\
\hline & 0.000 & & & & \\
\hline $\mathrm{C} 1 \mathrm{n}-\mathrm{C} 1 \mathrm{r} .1 \mathrm{r}$ & 0.781 & $1.10-1.15$ & 1.125 & $1 \mathrm{H}-1,112.5$ & Split core \\
\hline C1r.1r-C1r.1n & 0.988 & $1.40-1.65$ & 1.525 & Between Sections $1 \mathrm{H}-1$ and 2 & Split core \\
\hline $\mathrm{C} 1 \mathrm{r} .1 \mathrm{n}-\mathrm{C} 1 \mathrm{r} .2 \mathrm{r}$ & 1.072 & $1.75-1.80$ & 1.775 & $1 \mathrm{H}-1,27.5$ & Split core \\
\hline$C 1 r .2 r-C 2 n$ & 1.778 & $4.85-4.85$ & 4.850 & $2 \mathrm{H}-2,125.0$ & Split core \\
\hline $\mathrm{C} 2 \mathrm{n}-\mathrm{C} 2 \mathrm{r} .1 \mathrm{r}$ & 1.945 & $5.30-5.35$ & 5.325 & $2 \mathrm{H}-3,22.5$ & Split core \\
\hline$C 2 r .1 r-C 2 r .1 n$ & 2.128 & $5.95-5.95$ & 5.950 & $2 \mathrm{H}-3,85.0$ & Split core \\
\hline $\mathrm{C} 2 \mathrm{r} .1 \mathrm{n}-\mathrm{C} 2 \mathrm{r} .2 \mathrm{r}$ & 2.148 & $6.05-6.05$ & 6.050 & $2 \mathrm{H}-3,95.0$ & Split core \\
\hline C2r.2r-C2An. $1 n$ & 2.581 & $7.50-7.75$ & 7.625 & $2 \mathrm{H}-4,102.5$ & Split core \\
\hline C2An.1n-C2An.1r & 3.032 & $9.25-9.30$ & 9.275 & $2 \mathrm{H}-5,117.5$ & Split core \\
\hline C2An.1r-C2An.2n & 3.116 & $9.50-9.70$ & 9.600 & Between Sections $2 \mathrm{H}-5$ and 6 & Split core \\
\hline C $2 A n .2 n-C 2 A n .2 r$ & 3.207 & $10.00-10.00$ & 10.000 & $2 \mathrm{H}-6,40.0$ & Split core \\
\hline C2An.2r-C2An.3n & 3.330 & $10.20-10.20$ & 10.200 & $2 \mathrm{H}-6,60.0$ & Split core \\
\hline C2An.3n-C2Ar & 3.596 & & Below 11.40 & Below 2H-7, 30.0 & Split core \\
\hline Hiatus & & & & & \\
\hline C5En-C5Er & 18.524 & & & Not identified & \\
\hline C5Er-C6n & 18.748 & & Above 13.60 & Above $3 \mathrm{H}-2,50.0$ & Split core \\
\hline $\mathrm{C} 6 \mathrm{n}-\mathrm{C} 6 \mathrm{r}$ & 19.722 & $13.65-13.70$ & 13.675 & $3 \mathrm{H}-2,57.5$ & Split core \\
\hline C6r-C6An.1n & 20.040 & $14.00-14.05$ & 14.025 & $3 \mathrm{H}-2,92.5$ & Split core \\
\hline C6An.1n-C6An.1r & 20.213 & $14.30-14.35$ & 14.325 & $3 \mathrm{H}-2,122.5$ & Split core \\
\hline C6An.1r-C6An.2n & 20.439 & $14.50-14.70$ & 14.600 & Between Sections $3 \mathrm{H}-2$ and 3 & Split core \\
\hline C6An.2n-C6Ar & 20.709 & $15.15-15.20$ & 15.175 & $3 \mathrm{H}-3,57.5$ & Split core \\
\hline C6Ar-C6AAn & 21.083 & $15.75-15.80$ & 15.775 & $3 \mathrm{H}-3,117.5$ & Split core \\
\hline C6AAn-C6AAr.1r & 21.159 & $15.95-16.00$ & 15.975 & $3 \mathrm{H}-3,137.5$ & Split core \\
\hline C6AAr.1r-C6AAr.1n & 21.403 & $16.45-16.50$ & 16.475 & $3 \mathrm{H}-4,37.5$ & Split core \\
\hline C6AAr.1n-C6AAr.2r & 21.483 & $16.55-16.60$ & 16.575 & $3 \mathrm{H}-4,47.5$ & Split core \\
\hline C6AAr.2r-C6AAr.2n & 21.659 & $16.95-16.95$ & 16.950 & $3 \mathrm{H}-4,85.0$ & Split core \\
\hline C6AAr.2n-C6AAr.3r & 21.688 & $17.05-17.10$ & 17.075 & $3 \mathrm{H}-4,97.5$ & Split core \\
\hline C6AAr.3r-C6Bn.1n & 21.767 & $17.15-17.20$ & 17.175 & $3 \mathrm{H}-4,107.5$ & Split core \\
\hline C6Bn.1n-C6Bn.1r & 21.936 & $17.40-17.45$ & 17.425 & $3 \mathrm{H}-4,132.5$ & Split core \\
\hline C6Bn.1r-C6Bn.2n & 21.992 & $17.75-17.75$ & 17.750 & $3 \mathrm{H}-5,15.0$ & Split core \\
\hline $\mathrm{C} 6 \mathrm{Bn} .2 \mathrm{n}-\mathrm{C} 6 \mathrm{Br}$ & 22.268 & $18.35-18.40$ & 18.375 & $3 \mathrm{H}-5,77.5$ & Split core \\
\hline $\mathrm{C} 6 \mathrm{Br}-\mathrm{C} 6 \mathrm{Cn} .1 \mathrm{n}$ & 22.564 & & Below 19.50 & Below $3 \mathrm{H}-6,40.0$ & Split core \\
\hline C6Cn.1n-C6Cn.1r & 22.754 & & & Not identified & \\
\hline $\mathrm{C} 6 \mathrm{Cn} .1 \mathrm{r}-\mathrm{C} 6 \mathrm{Cn} .2 \mathrm{n}$ & 22.902 & & & Not identified & \\
\hline C 6 Cn.2n-C 6 Cn.2r & 23.030 & & & Not identified & \\
\hline C $6 C n .2 r-C 6 C n .3 n$ & 23.278 & & & Not identified & \\
\hline $\mathrm{C} 6 \mathrm{Cn} .3 \mathrm{n}-\mathrm{C} 6 \mathrm{Cr}$ & 23.340 & & Above 21.20 & Above $4 \mathrm{H}-2,10.0$ & Split core \\
\hline $\mathrm{C} 6 \mathrm{Cr}-\mathrm{C} 7 \mathrm{n} .1 \mathrm{n}$ & 24.022 & $22.50-22.50$ & 22.500 & $4 \mathrm{H}-2,140.0$ & Split core \\
\hline C7n.1n-C7n.1r & 24.062 & $22.50-22.70$ & 22.600 & Between Sections $4 \mathrm{H}-2$ and 3 & Split core \\
\hline C7n.1r-C7n.2n & 24.147 & $22.90-22.95$ & 22.925 & $4 \mathrm{H}-3,32.5$ & Split core \\
\hline $\mathrm{C} 7 \mathrm{n} \cdot 2 \mathrm{n}-\mathrm{C} 7 \mathrm{r}$ & 24.459 & $23.85-23.85$ & 23.850 & $4 \mathrm{H}-3,125.0$ & Split core \\
\hline C7r-C7An & 24.756 & $24.70-24.75$ & 24.725 & $4 \mathrm{H}-4,62.5$ & Split core \\
\hline C7An-C7Ar & 24.984 & $25.25-25.25$ & 25.250 & $4 \mathrm{H}-4,115.0$ & Split core \\
\hline C7Ar-C8n.1n & 25.110 & $25.50-25.70$ & 25.600 & Between Sections $4 \mathrm{H}-4$ and 5 & Split core \\
\hline C8n.1n-C8n.1r & 25.248 & $26.05-26.10$ & 26.075 & $4 \mathrm{H}-5,47.5$ & Split core \\
\hline C $8 n .1 r-C 8 n .2 n$ & 25.306 & $26.10-26.15$ & 26.125 & $4 \mathrm{H}-5,52.5$ & Split core \\
\hline $\mathrm{C} 8 \mathrm{n} \cdot 2 \mathrm{n}-\mathrm{C} 8 \mathrm{r}$ & 26.032 & $28.25-28.30$ & 28.275 & $4 \mathrm{H}-6,117.5$ & Split core \\
\hline $\mathrm{C} 8 \mathrm{r}-\mathrm{C} 9 \mathrm{n}$ & 26.508 & $30.45-30.45$ & 30.450 & $5 \mathrm{H}-1,135.0$ & Split core \\
\hline $\mathrm{C} 9 n-\mathrm{C} 9 \mathrm{r}$ & 27.412 & $34.65-34.70$ & 34.675 & $5 \mathrm{H}-4,107.5$ & Split core \\
\hline C9r-C10n.1n & 27.886 & $36.50-36.80$ & 36.650 & Between Sections $5 \mathrm{H}-5$ and 6 & Split core \\
\hline C10n.1n-C10n.1r & 28.126 & & Below 37.35 & Below $5 \mathrm{H}-6,75.0$ & Split core \\
\hline $\mathrm{C} 10 \mathrm{n} .1 \mathrm{r}-\mathrm{C} 10 \mathrm{n} .2 \mathrm{n}$ & 28.164 & & & Not identified & \\
\hline $\mathrm{C} 10 \mathrm{n} \cdot 2 \mathrm{n}-\mathrm{C} 10 \mathrm{r}$ & 28.318 & & Above 47.50 & Above $6 \mathrm{H}-2,60.0$ & Split core \\
\hline C10r-C11n.1n & 29.166 & $42.00-42.05$ & 42.025 & $6 \mathrm{H}-3,42.5$ & Split core \\
\hline C11n.1n-C11n.1r & 29.467 & $44.10-44.15$ & 44.125 & $6 \mathrm{H}-4,102.5$ & Split core \\
\hline $\mathrm{C} 11 \mathrm{n} .1 \mathrm{r}-\mathrm{C} 11 \mathrm{n} .2 \mathrm{n}$ & 29.536 & $44.35-44.40$ & 44.375 & $6 \mathrm{H}-4,127.5$ & Split core \\
\hline $\mathrm{C} 11 \mathrm{n} .2 \mathrm{n}-\mathrm{C} 11 \mathrm{r}$ & 29.957 & & Below 46.90 & Below $6 \mathrm{H}-6,80.0$ & Split core \\
\hline $\mathrm{C} 11 \mathrm{r}-\mathrm{C} 12 \mathrm{n}$ & 30.617 & & & Not identified & \\
\hline $\mathrm{C} 12 \mathrm{n}-\mathrm{C} 12 \mathrm{r}$ & 31.021 & & Above 48.80 & Above $7 \mathrm{H}-1,70.0$ & Split core \\
\hline $\mathrm{C} 12 \mathrm{r}-\mathrm{C} 13 \mathrm{n}$ & 33.232 & $65.95-65.95$ & 65.950 & $8 \mathrm{H}-6,85.0$ & Split core \\
\hline (repeated) & 33.232 & $71.25-71.25$ & 71.250 & $9 \mathrm{H}-3,115.0$ & Split core \\
\hline $\mathrm{C} 13 n-\mathrm{C} 13 \mathrm{r}$ & 33.705 & $74.30-74.35$ & 74.325 & $9 \mathrm{H}-5,122.5$ & Split core \\
\hline $\mathrm{C} 13 \mathrm{r}-\mathrm{C} 15 \mathrm{n}$ & 35.126 & & Below 76.00 & Below $9 \mathrm{H}-6,140.0$ & Split core \\
\hline $\mathrm{C} 15 n-C 15 r$ & 35.254 & & Above 78.20 & Above $10 \mathrm{H}-2,10.0$ & Split core \\
\hline C15r-C16n.1n & 35.328 & $79.20-79.30$ & 79.250 & $10 \mathrm{H}-2115.0$ & Split core \\
\hline C16n.1n-C16n.1r & 35.554 & $80.05-80.05$ & 80.050 & $10 \mathrm{H}-3,45.0$ & Split core \\
\hline C16n.1r-C16n.2n & 35.643 & $80.60-80.65$ & 80.625 & $10 \mathrm{H}-3,102.5$ & Split core \\
\hline
\end{tabular}


Table T25 (continued). (Continued on next page.)

\begin{tabular}{|c|c|c|c|c|c|}
\hline \multirow[b]{2}{*}{ Polarity chron } & \multirow[b]{2}{*}{$\begin{array}{l}\text { Age } \\
(\mathrm{Ma})\end{array}$} & \multicolumn{4}{|c|}{ Hole U1332C } \\
\hline & & $\begin{array}{l}\text { Range } \\
\operatorname{CSF}(\mathrm{m})\end{array}$ & $\begin{array}{l}\text { Best estimate } \\
\text { CSF }(\mathrm{m})\end{array}$ & $\begin{array}{l}\text { Best estimate core, } \\
\text { section, interval }(\mathrm{m})\end{array}$ & $\begin{array}{l}\text { Measurement } \\
\text { type }\end{array}$ \\
\hline & 0.000 & & & & \\
\hline $\mathrm{C} 1 \mathrm{n}-\mathrm{C} 1 \mathrm{r} .1 \mathrm{r}$ & 0.781 & $1.30-1.30$ & 1.300 & $1 \mathrm{H}-1,130.0$ & Split core \\
\hline C1r.1r-C1r.1n & 0.988 & $1.85-1.85$ & 1.850 & $1 \mathrm{H}-2,35.0$ & Split core \\
\hline $\mathrm{C} 1 \mathrm{r} .1 \mathrm{n}-\mathrm{C} 1 \mathrm{r} .2 \mathrm{r}$ & 1.072 & $2.10-2.10$ & 2.100 & $1 \mathrm{H}-2,60.0$ & Split core \\
\hline$C 1 r .2 r-C 2 n$ & 1.778 & $3.55-3.85$ & 3.700 & $1 \mathrm{H}-3,70.0$ & Split core \\
\hline $\mathrm{C} 2 \mathrm{n}-\mathrm{C} 2 \mathrm{r} .1 \mathrm{r}$ & 1.945 & $4.30-4.30$ & 4.300 & $1 \mathrm{H}-3,130.0$ & Split core \\
\hline $\mathrm{C} 2 \mathrm{r} .1 \mathrm{r}-\mathrm{C} 2 \mathrm{r} .1 \mathrm{n}$ & 2.128 & & & Not identified & \\
\hline $\mathrm{C} 2 \mathrm{r} .1 \mathrm{n}-\mathrm{C} 2 \mathrm{r} .2 \mathrm{r}$ & 2.148 & & & Not identified & \\
\hline $\mathrm{C} 2 \mathrm{r} .2 \mathrm{r}-\mathrm{C} 2 \mathrm{An} .1 \mathrm{n}$ & 2.581 & & & Not identified & \\
\hline C2An.1n-C2An.1r & 3.032 & & & Not identified & \\
\hline C2An.1r-C2An.2n & 3.116 & & & Not identified & \\
\hline C2An.2n-C2An.2r & 3.207 & & & Not identified & \\
\hline C2An.2r-C2An.3n & 3.330 & & & Not identified & \\
\hline $\mathrm{C} 2 \mathrm{An} .3 \mathrm{n}-\mathrm{C} 2 \mathrm{Ar}$ & 3.596 & & & Not identified & \\
\hline Hiatus & & & & & \\
\hline C5En-C5Er & 18.524 & $12.95-12.95$ & 12.950 & $2 \mathrm{H}-4,95.0$ & Split core \\
\hline C5Er-C6n & 18.748 & $13.15-13.20$ & 13.175 & $2 \mathrm{H}-4,117.5$ & Split core \\
\hline $\mathrm{C} 6 \mathrm{n}-\mathrm{C} 6 \mathrm{r}$ & 19.722 & $14.75-14.75$ & 14.750 & $2 \mathrm{H}-5,125.0$ & Split core \\
\hline C6r-C6An.1n & 20.040 & $15.20-15.20$ & 15.200 & $2 \mathrm{H}-6,20.0$ & Split core \\
\hline C6An.1n-C6An.1r & 20.213 & $15.60-15.65$ & 15.625 & $2 \mathrm{H}-6,62.5$ & Split core \\
\hline C6An.1r-C6An.2n & 20.439 & $16.05-16.10$ & 16.075 & $2 \mathrm{H}-6,107.5$ & Split core \\
\hline C6An.2n-C6Ar & 20.709 & $16.80-16.85$ & 16.825 & $2 \mathrm{H}-7,32.5$ & Split core \\
\hline C6Ar-C6AAn & 21.083 & & Below 17.25 & Below $2 \mathrm{H}-7,75.0$ & Split core \\
\hline C6AAn-C6AAr.1r & 21.159 & & & Not identified & \\
\hline C6AAr.1r-C6AAr.1n & 21.403 & & & Not identified & \\
\hline C6AAr.1n-C6AAr.2r & 21.483 & & & Not identified & \\
\hline C6AAr.2r-C6AAr.2n & 21.659 & & Above 18.60 & Above $3 \mathrm{H}-2,10.0$ & Split core \\
\hline C6AAr.2n-C6AAr.3r & 21.688 & $18.70-18.75$ & 18.725 & $3 \mathrm{H}-2,22.5$ & Split core \\
\hline C6AAr.3r-C6Bn.1n & 21.767 & $18.85-18.90$ & 18.875 & $3 \mathrm{H}-2,37.5$ & Split core \\
\hline C6Bn.1n-C6Bn.1r & 21.936 & $19.10-19.25$ & 19.175 & $3 \mathrm{H}-2,67.5$ & Split core \\
\hline C6Bn.1r-C6Bn.2n & 21.992 & $19.55-19.70$ & 19.625 & $3 \mathrm{H}-2,112.5$ & Split core \\
\hline $\mathrm{C} 6 \mathrm{Bn} \cdot 2 \mathrm{n}-\mathrm{C} 6 \mathrm{Br}$ & 22.268 & $20.30-20.30$ & 20.300 & $3 \mathrm{H}-3,30.0$ & Split core \\
\hline $\mathrm{C} 6 \mathrm{Br}-\mathrm{C} 6 \mathrm{Cn} .1 \mathrm{n}$ & 22.564 & $21.40-21.70$ & 21.550 & Between Sections $3 \mathrm{H}-3$ and 4 & Split core \\
\hline $\mathrm{C} 6 \mathrm{Cn} .1 \mathrm{n}-\mathrm{C} 6 \mathrm{Cn} .1 \mathrm{r}$ & 22.754 & $22.15-22.20$ & 22.175 & $3 \mathrm{H}-4,67.5$ & Split core \\
\hline C 6 Cn.1r-C6Cn.2n & 22.902 & $22.60-22.60$ & 22.600 & $3 \mathrm{H}-4,110.0$ & Split core \\
\hline C $6 C n .2 n-C 6 C n .2 r$ & 23.030 & $22.85-22.90$ & 22.875 & $3 \mathrm{H}-4,137.5$ & Split core \\
\hline C $6 C n .2 r-C 6 C n .3 n$ & 23.278 & $23.40-23.40$ & 23.400 & $3 \mathrm{H}-5,40.0$ & Split core \\
\hline $\mathrm{C} 6 \mathrm{Cn} .3 \mathrm{n}-\mathrm{C} 6 \mathrm{Cr}$ & 23.340 & $23.70-23.75$ & 23.725 & $3 \mathrm{H}-5,72.5$ & Split core \\
\hline $\mathrm{C} 6 \mathrm{Cr}-\mathrm{C} 7 \mathrm{n} .1 \mathrm{n}$ & 24.022 & $26.35-26.40$ & 26.375 & $3 \mathrm{H}-7,37.5$ & Split core \\
\hline C7n.1n-C7n.1r & 24.062 & $26.50-26.50$ & 26.500 & $3 \mathrm{H}-7,50.0$ & Split core \\
\hline C7n.1r-C7n.2n & 24.147 & & Below 26.65 & Below 3H-7, 65.0 & Split core \\
\hline$C 7 n \cdot 2 n-C 7 r$ & 24.459 & & & Not identified & \\
\hline C7r-C7An & 24.756 & & Above 26.70 & Above $4 \mathrm{H}-1,20.0$ & Split core \\
\hline C7An-C7Ar & 24.984 & $26.90-26.95$ & 26.925 & $4 \mathrm{H}-1,42.5$ & Split core \\
\hline C7Ar-C8n.1n & 25.110 & $27.40-27.40$ & 27.400 & $4 \mathrm{H}-1,90.0$ & Split core \\
\hline C8n.1n-C8n.1r & 25.248 & $27.90-28.10$ & 28.000 & Between $4 \mathrm{H}-1$ and 2 & Split core \\
\hline C $8 n .1 r-C 8 n .2 n$ & 25.306 & $27.90-28.10$ & 28.000 & Between $4 \mathrm{H}-1$ and 2 & Split core \\
\hline $\mathrm{C} 8 \mathrm{n} .2 \mathrm{n}-\mathrm{C} 8 \mathrm{r}$ & 26.032 & $30.55-30.85$ & 30.700 & $4 \mathrm{H}-3,120.0$ & Split core \\
\hline $\mathrm{C} 8 \mathrm{r}-\mathrm{C} 9 \mathrm{n}$ & 26.508 & $32.35-32.40$ & 32.375 & $4 \mathrm{H}-4,137.5$ & Split core \\
\hline $\mathrm{C} 9 n-\mathrm{C} 9 \mathrm{r}$ & 27.412 & & Below 36.15 & Below 4H-7, 65.0 & Split core \\
\hline C9r-C10n.1n & 27.886 & $36.85-36.90$ & 36.875 & $5 \mathrm{H}-1,87.5$ & Split core \\
\hline C10n.1n-C10n.1r & 28.126 & $37.90-37.95$ & 37.927 & $5 \mathrm{H}-2,42.5$ & Split core \\
\hline C10n.1r-C10n.2n & 28.164 & $38.15-38.20$ & 38.175 & $5 \mathrm{H}-2,67.5$ & Split core \\
\hline $\mathrm{C} 10 \mathrm{n} .2 \mathrm{n}-\mathrm{C} 10 \mathrm{r}$ & 28.318 & $38.65-38.70$ & 38.675 & $5 \mathrm{H}-2,117.5$ & Split core \\
\hline C10r-C11n.1n & 29.166 & $44.70-44.75$ & 44.725 & $5 \mathrm{H}-6,122.5$ & Split core \\
\hline C11n.1n-C11n.1r & 29.467 & & Below 45.45 & Below $5 \mathrm{H}-7,45.0$ & Split core \\
\hline $\mathrm{C} 11 \mathrm{n} .1 \mathrm{r}-\mathrm{C} 11 \mathrm{n} .2 \mathrm{n}$ & 29.536 & $45.75-45.80$ & 45.775 & $6 \mathrm{H}-2,137.5$ & Split core \\
\hline $\mathrm{C} 11 \mathrm{n} .2 \mathrm{n}-\mathrm{C} 11 \mathrm{r}$ & 29.957 & $47.85-47.90$ & 47.875 & $6 \mathrm{H}-4,47.5$ & Split core \\
\hline $\mathrm{C} 11 \mathrm{r}-\mathrm{C} 12 \mathrm{n}$ & 30.617 & $50.25-50.30$ & 50.275 & $7 \mathrm{H}-1,77.5$ & Split core \\
\hline $\mathrm{C} 12 \mathrm{n}-\mathrm{C} 12 \mathrm{r}$ & 31.021 & $52.20-52.20$ & 52.200 & 7H-2, 120.0 & Split core \\
\hline $\mathrm{C} 12 \mathrm{r}-\mathrm{C} 13 \mathrm{n}$ & 33.232 & & Below 67.85 & Between Cores $8 \mathrm{H}$ and $9 \mathrm{H}$ & Split core \\
\hline (repeated) & 33.232 & $74.05-74.10$ & 74.075 & $9 \mathrm{H}-6,57.5$ & Split core \\
\hline $\mathrm{C} 13 n-\mathrm{C} 13 \mathrm{r}$ & 33.705 & & Below 75.50 & Below 9H-7, 50.0 & Split core \\
\hline $\mathrm{C} 13 \mathrm{r}-\mathrm{C} 15 \mathrm{n}$ & 35.126 & & & Not identified & \\
\hline $\mathrm{C} 15 n-\mathrm{C} 15 \mathrm{r}$ & 35.254 & & & Not identified & \\
\hline C15r-C16n.1n & 35.328 & & & Not identified & \\
\hline $\mathrm{C} 16 \mathrm{n} .1 \mathrm{n}-\mathrm{C} 16 \mathrm{n} .1 \mathrm{r}$ & 35.554 & & & Not identified & \\
\hline $\mathrm{C} 16 n .1 r-C 16 n .2 n$ & 35.643 & & & Not identified & \\
\hline
\end{tabular}


Table T25 (continued). (Continued on next page.)

\begin{tabular}{lccccc}
\hline & & \multicolumn{3}{c}{ Hole U1332A } \\
\cline { 3 - 6 } \multicolumn{1}{c}{ Polarity chron } & $\begin{array}{c}\text { Age } \\
\text { (Ma) }\end{array}$ & $\begin{array}{c}\text { Range } \\
\text { CSF }(\mathrm{m})\end{array}$ & $\begin{array}{c}\text { Best estimate } \\
\text { CSF }(\mathrm{m})\end{array}$ & $\begin{array}{c}\text { Best estimate core, } \\
\text { section, interval (cm) }\end{array}$ & $\begin{array}{c}\text { Measurement } \\
\text { type }\end{array}$ \\
\hline C16n.2n-C16r & 36.355 & $85.80-86.00$ & 85.900 & Between Sections 10H-4 and 5 & Split core \\
C16r-C17n.1n & 36.668 & $87.30-87.50$ & 87.400 & Between Sections 10H-5 and 6 & Split core \\
C17n.1n-C17n.1r & 37.520 & $92.50-92.60$ & 92.550 & $11 \mathrm{H}-3,15.0$ & Split core \\
C17n.1r-C17n.2n & 37.656 & $92.90-92.95$ & 92.925 & $11 \mathrm{H}-3,52.5$ & Split core \\
C17n.2n-C17n.2r & 37.907 & $94.05-94.10$ & 94.075 & $11 \mathrm{H}-4,17.5$ & Split core \\
C17n.2r-C17n.3n & 37.956 & $94.35-94.40$ & 94.375 & $11 \mathrm{H}-4,47.5$ & Split core \\
C17n.3n-C17r & 38.159 & $95.25-95.30$ & 95.275 & $11 \mathrm{H}-4,137.5$ & Split core \\
C17r-C18n.1n & 38.449 & $96.50-96.55$ & 96.525 & $11 \mathrm{H}-5,112.5$ & Split core \\
C18n.1n-C18n.1r & 39.554 & $101.80-102.00$ & 101.900 & Between Sections 12H-2 and 3 & Split core \\
C18n.1r-C18n.2n & 39.602 & $102.60-102.60$ & 102.600 & $12 \mathrm{H}-3,70.0$ & Split core \\
C18n.2n-C18r & 40.084 & $106.20-106.50$ & 106.350 & Between Sections 12H-5 and 6 & Split core \\
C18r-C19n & 41.358 & $117.25-117.25$ & 117.250 & $13 \mathrm{H}-6,135.0$ & Split core \\
C19n-C19r & 41.510 & & Above 119.50 & Above 14H-2, 10.0 & Split core \\
C19r-C20n & 42.536 & $124.70-124.70$ & 124.700 & $14 \mathrm{H}-5,80.0$ & Split core \\
\hline
\end{tabular}

Note: When the location of a reversal is listed as between sections, it could occur anywhere within $10 \mathrm{~cm}$ of the juxtaposing ends of the two sections listed. 
Table T25 (continued). (Continued on next page.)

\begin{tabular}{|c|c|c|c|c|c|}
\hline \multirow[b]{2}{*}{ Polarity chron } & \multirow[b]{2}{*}{$\begin{array}{l}\text { Age } \\
(\mathrm{Ma})\end{array}$} & \multicolumn{4}{|c|}{ Hole U1332B } \\
\hline & & $\begin{array}{l}\text { Range } \\
\text { CSF }(\mathrm{m})\end{array}$ & $\begin{array}{l}\text { Best estimate } \\
\text { CSF }(m)\end{array}$ & $\begin{array}{l}\text { Best estimate core, } \\
\text { section, interval }(\mathrm{cm})\end{array}$ & $\begin{array}{l}\text { Measurement } \\
\text { type }\end{array}$ \\
\hline $\mathrm{C} 16 n \cdot 2 n-C 16 r$ & 36.355 & $83.70-83.75$ & 83.725 & $10 \mathrm{H}-5,112.5$ & Split core \\
\hline $\mathrm{C} 16 \mathrm{r}-\mathrm{C} 17 \mathrm{n} .1 \mathrm{n}$ & 36.668 & $85.05-85.05$ & 85.050 & $10 \mathrm{H}-6,95.0$ & Split core \\
\hline C17n.1n-C17n.1r & 37.520 & $89.60-89.65$ & 89.625 & $11 \mathrm{H}-3,52.5$ & Split core \\
\hline C17n.1r-C17n.2n & 37.656 & $90.25-90.30$ & 90.275 & $11 \mathrm{H}-3,117.5$ & Split core \\
\hline C17n.2n-C17n.2r & 37.907 & $91.35-91.35$ & 91.350 & $11 \mathrm{H}-4,75.0$ & Split core \\
\hline C17n.2r-C17n.3n & 37.956 & $91.65-91.65$ & 91.650 & $11 \mathrm{H}-4,105.0$ & Split core \\
\hline $\mathrm{C} 17 n \cdot 3 n-C 17 r$ & 38.159 & $92.45-92.50$ & 92.475 & $11 \mathrm{H}-5,37.5$ & Split core \\
\hline $\mathrm{C} 17 \mathrm{r}-\mathrm{C} 18 \mathrm{n} .1 \mathrm{n}$ & 38.449 & & Below 93.50 & Below $11 \mathrm{H}-5,140.0$ & Split core \\
\hline C18n.1n-C18n.1r & 39.554 & $98.70-98.75$ & 98.725 & $12 \mathrm{H}-6,12.5$ & Split core \\
\hline $\mathrm{C} 18 \mathrm{n} .1 \mathrm{r}-\mathrm{C} 18 \mathrm{n} .2 \mathrm{n}$ & 39.602 & $99.30-99.35$ & 99.325 & $12 \mathrm{H}-672.5$ & Split core \\
\hline $\mathrm{C} 18 n \cdot 2 n-C 18 r$ & 40.084 & $102.20-102.30$ & 102.250 & $13 \mathrm{H}-2,15.0$ & Split core \\
\hline $\mathrm{C} 18 \mathrm{r}-\mathrm{C} 19 \mathrm{n}$ & 41.358 & & Below 110.35 & Below $13 \mathrm{H}-7,75.0$ & Split core \\
\hline $\mathrm{C} 19 n-C 19 r$ & 41.510 & & & Not identified & \\
\hline C19r-C20n & 42.536 & & & Not identified & \\
\hline
\end{tabular}


Table T25 (continued).

\begin{tabular}{|c|c|c|c|c|c|}
\hline \multirow[b]{2}{*}{ Polarity chron } & \multirow[b]{2}{*}{$\begin{array}{l}\text { Age } \\
\text { (Ma) }\end{array}$} & \multicolumn{4}{|c|}{ Hole U1332C } \\
\hline & & $\begin{array}{l}\text { Range } \\
\text { CSF (m) }\end{array}$ & $\begin{array}{l}\text { Best estimate } \\
\text { CSF }(m)\end{array}$ & $\begin{array}{l}\text { Best estimate core, } \\
\text { section, interval }(\mathrm{m})\end{array}$ & $\begin{array}{l}\text { Measurement } \\
\text { type }\end{array}$ \\
\hline $\mathrm{C} 16 n \cdot 2 n-C 16 r$ & 36.355 & & Above 86.15 & Above $11 \mathrm{H}-1,115.0$ & Split core \\
\hline $\mathrm{C} 16 \mathrm{r}-\mathrm{C} 17 \mathrm{n} .1 \mathrm{n}$ & 36.668 & $86.95-87.05$ & 87.000 & $11 \mathrm{H}-2,50.0$ & Split core \\
\hline C17n.1n-C17n.1r & 37.520 & $92.20-92.20$ & 92.200 & $11 \mathrm{H}-5,120.0$ & Split core \\
\hline C17n.1r-C17n.2n & 37.656 & $92.80-92.85$ & 92.825 & $11 \mathrm{H}-6,32.5$ & Split core \\
\hline C17n.2n-C17n.2r & 37.907 & & Below 93.65 & Below 11H-6, 115.0 & Split core \\
\hline C17n.2r-C17n.3n & 37.956 & & & Not identified & \\
\hline $\mathrm{C} 17 n \cdot 3 n-C 17 r$ & 38.159 & & Above 94.60 & Above $12 \mathrm{H}-1,10.0$ & Split core \\
\hline $\mathrm{C} 17 \mathrm{r}-\mathrm{C} 18 \mathrm{n} .1 \mathrm{n}$ & 38.449 & $94.95-95.00$ & 94.975 & Below 12H-1, 47.5 & Split core \\
\hline C18n.1n-C18n.1r & 39.554 & $100.35-100.40$ & 100.375 & $12 \mathrm{H}-4,137.5$ & Split core \\
\hline C18n.1r-C18n.2n & 39.602 & $100.40-100.60$ & 100.500 & $12 \mathrm{H}-5,10.0$ & Split core \\
\hline $\mathrm{C} 18 n \cdot 2 n-C 18 r$ & 40.084 & 106.80-107.10 & 106.950 & Between Sections $13 \mathrm{H}-2$ and 3 & Split core \\
\hline $\mathrm{C} 18 \mathrm{r}-\mathrm{C} 19 \mathrm{n}$ & 41.358 & & Below 113.70 & Below $13 \mathrm{H}-7,70.0$ & Split core \\
\hline $\mathrm{C} 19 n-\mathrm{C} 19 \mathrm{r}$ & 41.510 & & & Not identified & \\
\hline C19r-C20n & 42.536 & & & Not identified & \\
\hline
\end{tabular}


Table T26. Interstitial water data from squeezed whole-round samples, Site U1332. (See table notes.)

\begin{tabular}{|c|c|c|c|c|c|c|c|c|c|c|c|c|c|c|c|c|c|c|c|}
\hline \multirow{2}{*}{$\begin{array}{l}\text { Core, section, } \\
\text { interval }(\mathrm{cm})\end{array}$} & \multicolumn{2}{|c|}{ Depth (m) } & \multirow[b]{2}{*}{$\mathrm{pH}$} & \multirow{2}{*}{$\begin{array}{l}\text { Alkalinity } \\
(\mathrm{mM})\end{array}$} & \multirow[b]{2}{*}{ Salinity } & \multirow{2}{*}{$\begin{array}{c}\mathrm{Cl}^{-} \\
(\mathrm{mM})\end{array}$} & \multirow{2}{*}{$\begin{array}{l}\mathrm{Na}^{+} \\
(\mathrm{mM})\end{array}$} & \multirow{2}{*}{$\begin{array}{l}\mathrm{SO}_{4}{ }^{2-} \\
(\mathrm{mM})\end{array}$} & \multirow{2}{*}{$\begin{array}{c}\mathrm{HPO}_{4}^{2-} \\
(\mu \mathrm{M})\end{array}$} & \multirow{2}{*}{$\begin{array}{c}\mathrm{H}_{4} \mathrm{SiO}_{4} \\
(\mu \mathrm{M})\end{array}$} & \multirow{2}{*}{$\begin{array}{l}\mathrm{Mn}^{2+} \\
(\mu \mathrm{M})\end{array}$} & \multirow{2}{*}{$\begin{array}{l}\mathrm{Fe}^{2+} \\
(\mu \mathrm{M})\end{array}$} & \multirow{2}{*}{$\begin{array}{l}\mathrm{Ca}^{2+} \\
(\mathrm{mM})\end{array}$} & \multirow{2}{*}{$\begin{array}{l}\mathrm{Mg}^{2+} \\
(\mathrm{mM})\end{array}$} & \multirow{2}{*}{$\begin{array}{c}\mathrm{B} \\
(\mu \mathrm{M})\end{array}$} & \multirow{2}{*}{$\begin{array}{l}\mathrm{Sr}^{2+} \\
(\mu \mathrm{M})\end{array}$} & \multirow{2}{*}{$\begin{array}{l}\mathrm{Ba}^{2+} \\
(\mu \mathrm{M})\end{array}$} & \multirow{2}{*}{$\begin{array}{c}\mathrm{Li}^{+} \\
(\mu \mathrm{M})\end{array}$} & \multirow{2}{*}{$\begin{array}{c}\mathrm{K}^{+} \\
(\mathrm{mM})\end{array}$} \\
\hline & CSF & CCSF-A & & & & & & & & & & & & & & & & & \\
\hline \multicolumn{20}{|l|}{ 320-U1332A- } \\
\hline $1 \mathrm{H}-2,145-150$ & 2.95 & 2.95 & 7.57 & 2.35 & 34.0 & 555 & 483 & 28.6 & 2.13 & 499 & $\mathrm{BDL}$ & $\mathrm{BDL}$ & 10.0 & 50.4 & 431 & 81.6 & 2.2 & 25.8 & 11.01 \\
\hline $2 \mathrm{H}-2,145-150$ & 6.85 & 7.16 & 7.40 & 2.61 & 34.0 & 556 & 481 & 27.6 & 1.28 & 518 & 8.8 & $\mathrm{BDL}$ & 10.3 & 50.6 & 489 & 86.5 & 2.2 & 25.8 & 11.32 \\
\hline $2 \mathrm{H}-5,145-150$ & 11.35 & 11.66 & 7.36 & 2.85 & 34.0 & 559 & 483 & 27.6 & 1.08 & 497 & 7.8 & 0.97 & 10.3 & 50.8 & 484 & 78.3 & 2.3 & 24.0 & 11.53 \\
\hline $3 \mathrm{H}-2,145-150$ & 16.35 & 17.00 & 7.52 & 3.05 & - & 562 & 489 & 29.7 & 0.63 & 502 & $\mathrm{BDL}$ & 0.37 & 10.7 & 51.2 & 455 & 84.9 & 2.4 & 26.1 & 11.47 \\
\hline $3 \mathrm{H}-5,145-150$ & 20.85 & 21.50 & 7.43 & 2.88 & - & 564 & 490 & 28.8 & 0.62 & 548 & $\mathrm{BDL}$ & $\mathrm{BDL}$ & 10.7 & 51.0 & 466 & 85.5 & 2.3 & 26.2 & 11.54 \\
\hline $4 \mathrm{H}-2,145-150$ & 25.85 & 28.50 & 7.43 & 3.02 & 34.5 & 565 & 487 & 27.9 & BDL & 518 & $\mathrm{BDL}$ & $\mathrm{BDL}$ & 10.8 & 51.9 & 468 & 85.1 & 2.3 & 25.2 & 11.47 \\
\hline $4 \mathrm{H}-5,145-150$ & 30.35 & 33.00 & 7.44 & 2.87 & - & 565 & 485 & 27.5 & 0.64 & 562 & $\mathrm{BDL}$ & $\mathrm{BDL}$ & 10.7 & 52.5 & 467 & 82.6 & 2.2 & 24.5 & 11.22 \\
\hline $5 \mathrm{H}-2,145-150$ & 35.35 & 40.50 & 7.58 & 2.62 & 34.5 & 565 & 486 & 28.1 & BDL & 548 & $\mathrm{BDL}$ & $\mathrm{BDL}$ & 10.6 & 52.6 & 471 & 87.5 & 2.3 & 25.6 & 11.25 \\
\hline $5 \mathrm{H}-5,1$ & 39.85 & 45.00 & 7.41 & 2.3 & 34. & 567 & 491 & 28.3 & BDL & 568 & $\mathrm{BD}$ & $\mathrm{BDL}$ & 10.4 & 51.5 & 460 & 86.2 & 2.5 & 25.5 & 11.16 \\
\hline $6 \mathrm{H}-3,145-150$ & 46.35 & 52.00 & 7.41 & 2.89 & 34.5 & 568 & 491 & 26.8 & BDL & 616 & $\mathrm{BDL}$ & $\mathrm{BDL}$ & 10.4 & 50.9 & 441 & 81.8 & 2.2 & 24.0 & 11.10 \\
\hline $6 \mathrm{H}-5,145-150$ & 49.35 & 55.00 & 7.39 & 3.02 & 34.5 & 565 & 489 & 26.8 & BDL & 604 & $\mathrm{BDL}$ & $\mathrm{BDL}$ & 10.2 & 50.8 & 421 & 76.7 & 2.5 & 22.5 & 10.71 \\
\hline $7 \mathrm{H}-3,145-150$ & 55.85 & 63.75 & 7.40 & 3.07 & - & 568 & 489 & 27.3 & BDL & 550 & $\mathrm{BDL}$ & $\mathrm{BDL}$ & 10.7 & 51.9 & 420 & 81.1 & 2.7 & 22.4 & 10.94 \\
\hline $8 \mathrm{H}-3,145-150$ & 65.35 & 72.85 & 7.40 & 2.97 & 34.5 & 568 & 489 & 26.7 & 0.70 & 575 & $\mathrm{BDL}$ & $\mathrm{BDL}$ & 10.8 & 51.4 & 420 & 83.0 & 2.5 & 22.0 & 10.75 \\
\hline $9 \mathrm{H}-3,145-150$ & 74.85 & 77.63 & 7.39 & 3.05 & 34.5 & 568 & 490 & 27.6 & BDL & 493 & $\mathrm{BDL}$ & 0.32 & 10.9 & 51.6 & 431 & 86.4 & 2.5 & 22.6 & 10.82 \\
\hline $10 \mathrm{H}-3,145-150$ & 84.35 & 87.83 & - & - & 34.0 & 563 & 484 & 28.1 & BDL & 374 & $\mathrm{BDL}$ & 0.36 & 11.3 & 51.1 & 421 & 89.1 & 2.9 & 22.3 & 10.44 \\
\hline $11 \mathrm{H}-3,145-150$ & 93.85 & 97.17 & 7.51 & 3.19 & 34.0 & 566 & 489 & 27.5 & BDL & 810 & $\mathrm{BD}$ & $\mathrm{BDL}$ & 11.2 & 51.1 & 406 & 82.3 & 2.3 & 21.4 & 10.15 \\
\hline $12 \mathrm{H}-3,145-150$ & 103.35 & 109.37 & 7.58 & 3.16 & 34.5 & 565 & 487 & 26.6 & BDL & 883 & $\mathrm{BDL}$ & $\mathrm{BDL}$ & 11.5 & 50.6 & 399 & 84.1 & 2.4 & 20.4 & 10.30 \\
\hline $13 \mathrm{H}-3,145-150$ & 112.85 & 120.62 & 7.41 & 3.26 & 34.0 & 569 & 489 & 26.7 & BDL & 917 & $\mathrm{BDL}$ & 0.29 & 11.5 & 51.4 & 413 & 84.1 & 3.1 & 21.0 & 10.34 \\
\hline $14 \mathrm{H}-3,145-150$ & 122.35 & 133.87 & 7.56 & 3.36 & 34.5 & 567 & 487 & 27.0 & BDL & 909 & $\mathrm{BDL}$ & 0.44 & 11.7 & 51.8 & 418 & 84.6 & 2.8 & 20.9 & 10.31 \\
\hline $15 X-3,140-150$ & 130.30 & 142.82 & 7.51 & 3.29 & 34.5 & 562 & 481 & 26.1 & BDL & 1004 & $\mathrm{BDL}$ & 0.41 & 11.8 & 51.2 & 453 & 93.0 & 2.6 & 21.1 & 10.10 \\
\hline
\end{tabular}

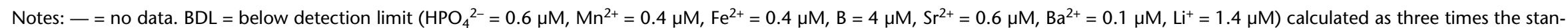
dard deviation of multiple measures of a blank. $\mathrm{H}_{4} \mathrm{SiO}_{4}$ values measured by different techniques during Expeditions 320 and 321 disagree significantly, especially for low values. Therefore, caution should be used concerning the $\mathrm{H}_{4} \mathrm{SiO}_{4}$ data and comparison between the different expeditions. 
Table T27. Interstitial water data from rhizon samples, Sections 320-U1332C-4H-1 through 7H-6. (See table notes.)

\begin{tabular}{|c|c|c|c|c|c|c|c|c|c|c|c|c|c|c|c|c|c|c|c|}
\hline \multirow{2}{*}{$\begin{array}{l}\text { Core, section, } \\
\text { interval }(\mathrm{cm})\end{array}$} & \multicolumn{2}{|c|}{ Depth (m) } & \multirow[b]{2}{*}{$\mathrm{pH}$} & \multirow{2}{*}{$\begin{array}{c}\text { Alkalinity } \\
(\mathrm{mM})\end{array}$} & \multirow[b]{2}{*}{ Salinity } & \multirow{2}{*}{$\underset{(\mathrm{mM})}{\mathrm{Cl}^{-}}$} & \multirow{2}{*}{$\begin{array}{c}\mathrm{Na}^{+} \\
(\mathrm{mM})\end{array}$} & \multirow{2}{*}{$\begin{array}{l}\mathrm{SO}_{4}^{2-} \\
(\mathrm{mM})\end{array}$} & \multirow{2}{*}{$\begin{array}{c}\mathrm{HPO}_{4}{ }^{2-} \\
(\mu \mathrm{M})\end{array}$} & \multirow{2}{*}{$\begin{array}{c}\mathrm{H}_{4} \mathrm{SiO}_{4} \\
(\mu \mathrm{M})\end{array}$} & \multirow{2}{*}{$\begin{array}{l}\mathrm{Mn}^{2+} \\
(\mu \mathrm{M})\end{array}$} & \multirow{2}{*}{$\begin{array}{l}\mathrm{Fe}^{2+} \\
(\mu \mathrm{M})\end{array}$} & \multirow{2}{*}{$\begin{array}{l}\mathrm{Ca}^{2+} \\
(\mathrm{mM})\end{array}$} & \multirow{2}{*}{$\begin{array}{l}\mathrm{Mg}^{2+} \\
(\mathrm{mM})\end{array}$} & \multirow{2}{*}{$\begin{array}{c}B \\
(\mu M)\end{array}$} & \multirow{2}{*}{$\begin{array}{l}\mathrm{Sr}^{2+} \\
(\mu \mathrm{M})\end{array}$} & $\mathrm{Ba}^{2+}$ & & \\
\hline & CSF & CCSF-A & & & & & & & & & & & & & & & $(\mu \mathrm{M})$ & $(\mu \mathrm{M})$ & $\mathrm{nM})$ \\
\hline 20-U1332C & & & & & & & & & & & & & & & & & & & \\
\hline $4 \mathrm{H}-1,55$ & 27.05 & 29.50 & ND & ND & ND & ND & ND & ND & ND & ND & 0.31 & $\mathrm{BDL}$ & 10.4 & 50.7 & 465 & 83.6 & 0.83 & 24.3 & 11.1 \\
\hline $4 \mathrm{H}-1,130$ & 27.80 & 30.25 & 7.48 & 2.86 & ND & ND & ND & ND & ND & ND & $\mathrm{BDL}$ & $\mathrm{BDL}$ & 10.5 & 51.0 & 472 & 82.3 & 0.78 & 24.1 & 11.3 \\
\hline $4 \mathrm{H}-2,55$ & 28.55 & 31.00 & 7.54 & 2.97 & ND & ND & ND & ND & ND & ND & $\mathrm{BDL}$ & $\mathrm{BDL}$ & 10.5 & 49.9 & 474 & 87.3 & 0.87 & 25.4 & 11.4 \\
\hline $4 \mathrm{H}-2,130$ & 29.30 & 31.75 & 7.64 & 3.10 & ND & ND & ND & ND & ND & ND & 0.24 & $\mathrm{BDL}$ & 10.6 & 49.8 & 464 & 86.9 & 0.82 & 25.0 & 11.2 \\
\hline $4 \mathrm{H}-3,55$ & 30.05 & 32.50 & 7.54 & 2.95 & ND & ND & ND & ND & ND & ND & $\mathrm{BDL}$ & $\mathrm{BDL}$ & 10.6 & 51.2 & 473 & 86.1 & 0.80 & 24.7 & 11.3 \\
\hline $4 \mathrm{H}-3,130$ & 30.80 & 33.25 & 7.49 & 2.82 & ND & ND & ND & ND & ND & ND & $\mathrm{BDL}$ & 0.52 & 10.3 & 50.2 & 477 & 83.2 & 0.77 & 24.3 & 11.0 \\
\hline $4 \mathrm{H}-4,55$ & 31.55 & 34.00 & 7.50 & 2.82 & ND & ND & ND & ND & ND & ND & 1.34 & 0.68 & 10.5 & 50.1 & 434 & 72.9 & 0.83 & 21.5 & 11.1 \\
\hline $4 \mathrm{H}-4,130$ & 32.30 & 34.75 & 7.34 & 2.78 & ND & ND & ND & ND & ND & ND & $\mathrm{BDL}$ & 0.69 & 10.4 & 50.9 & 476 & 82.1 & 1.02 & 23.6 & 11.2 \\
\hline $4 \mathrm{H}-5,55$ & 33.05 & 35.50 & 7.47 & 2.75 & ND & ND & ND & ND & ND & ND & $\mathrm{BDL}$ & $\mathrm{BDL}$ & 10.4 & 51.1 & 472 & 82.5 & 1.03 & 23.8 & 11.2 \\
\hline $4 \mathrm{H}-5,130$ & 33.80 & 36.25 & 7.41 & 2.77 & ND & ND & ND & ND & ND & ND & $\mathrm{BDL}$ & $\mathrm{BDL}$ & 10.3 & 50.8 & 472 & 80.0 & 1.00 & 23.3 & 11.2 \\
\hline $4 \mathrm{H}-6,55$ & 34.55 & 37.00 & 7.46 & 2.42 & ND & ND & ND & ND & ND & ND & $\mathrm{BDL}$ & $\mathrm{BDL}$ & 10.1 & 50.5 & 486 & 84.8 & 0.78 & 24.7 & 11.4 \\
\hline $4 \mathrm{H}-6,130$ & 35.30 & 37.75 & 7.85 & 2.84 & ND & ND & ND & ND & ND & ND & 0.22 & $\mathrm{BDL}$ & 10.0 & 50.4 & 493 & 85.7 & 0.82 & 25.0 & 11.0 \\
\hline $5 \mathrm{H}-1,55$ & 36.55 & 40.80 & 7.43 & 2.83 & ND & ND & $\mathrm{NL}$ & ND & ND & ND & 0.24 & $\mathrm{BDL}$ & 10.3 & 50.6 & 465 & 81.4 & 0.78 & 24.0 & 11.2 \\
\hline $5 \mathrm{H}-1,130$ & 37.30 & 41.55 & 7.46 & 2.79 & ND & ND & ND & ND & ND & ND & $\mathrm{BDL}$ & $\mathrm{BDL}$ & 10.2 & 51.1 & 457 & 81.9 & 0.79 & 24.0 & 11.0 \\
\hline $5 \mathrm{H}-2,55$ & 38.05 & 42.30 & 7.47 & 2.74 & ND & ND & ND & ND & ND & ND & $\mathrm{BDL}$ & 0.58 & 10.1 & 50.8 & 474 & 82.4 & 0.77 & 24.1 & 11.1 \\
\hline $5 \mathrm{H}-2,130$ & 38.80 & 43.05 & 7.42 & 2.71 & ND & ND & ND & $\mathrm{NL}$ & NL & ND & $\mathrm{BDL}$ & $\mathrm{BDL}$ & 10.1 & 50.8 & 473 & 82.4 & 0.77 & 24.5 & 11.1 \\
\hline $5 \mathrm{H}-3,55$ & 39.55 & 43.80 & 7.43 & 2.80 & ND & ND & ND & ND & ND & ND & 0.26 & $\mathrm{BDL}$ & 10.0 & 50.3 & 464 & 82.7 & 0.82 & 24.2 & 10.7 \\
\hline $5 \mathrm{H}-3,130$ & 40.30 & 44.55 & 7.46 & 2.70 & ND & ND & ND & ND & ND & ND & 0.22 & 0.54 & 10.1 & 50.0 & 480 & 81.4 & 0.80 & 23.6 & 11.2 \\
\hline $5 \mathrm{H}-4,55$ & 41.05 & 45.30 & 7.50 & 2.71 & ND & ND & $\mathrm{NL}$ & $\mathrm{NL}$ & $\mathrm{NI}$ & ND & 0.40 & 1.99 & 10.2 & 50.5 & 510 & 87.2 & 0.85 & 25.1 & 11.4 \\
\hline $5 \mathrm{H}-4,130$ & 41.80 & 46.05 & 7.44 & 2.80 & ND & ND & ND & ND & ND & ND & 0.32 & $\mathrm{BDL}$ & 10.1 & 51.2 & 455 & 80.2 & 0.79 & 23.6 & 11.1 \\
\hline $5 \mathrm{H}-5,55$ & 42.55 & 46.80 & 7.42 & 2.84 & ND & ND & ND & ND & ND & ND & 0.27 & $\mathrm{BDL}$ & 9.9 & 50.6 & 471 & 82.5 & 0.84 & 24.7 & 11.0 \\
\hline $5 \mathrm{H}-5,130$ & 43.30 & 47.55 & 7.46 & 2.84 & ND & ND & $\mathrm{NL}$ & $\mathrm{NL}$ & $\mathrm{NL}$ & ND & 0.27 & $\mathrm{BDL}$ & 9.9 & 51.0 & 459 & 82.5 & 0.83 & 24.8 & 10.7 \\
\hline $5 \mathrm{H}-6,55$ & 44.05 & 48.30 & 7.41 & 2.82 & ND & ND & ND & ND & ND & ND & 0.37 & $\mathrm{BDL}$ & 9.9 & 50.9 & 447 & 79.7 & 0.79 & 24.0 & 10.7 \\
\hline $5 \mathrm{H}-6,130$ & 44.80 & 49.05 & 7.44 & 2.79 & ND & ND & ND & ND & ND & ND & 0.23 & $\mathrm{BDL}$ & 9.9 & 49.9 & 465 & 81.4 & 0.79 & 23.6 & 10.9 \\
\hline $6 \mathrm{H}-2,130$ & 48.30 & 51.75 & 7.47 & 2.77 & ND & ND & $\mathrm{NL}$ & $\mathrm{NL}$ & $\mathrm{NL}$ & ND & $\mathrm{BDL}$ & $\mathrm{BDL}$ & 10.2 & 49.8 & 468 & 81.1 & 0.76 & 22.9 & 10.8 \\
\hline $6 \mathrm{H}-3,55$ & 49.05 & 52.50 & 7.45 & ND & ND & ND & ND & ND & ND & ND & 0.22 & $\mathrm{BDL}$ & 10.2 & 51.5 & 454 & 81.6 & 0.81 & 23.5 & 11.0 \\
\hline $6 \mathrm{H}-3,130$ & 49.80 & 53.25 & 7.45 & 2.77 & ND & ND & ND & ND & ND & ND & 0.24 & $\mathrm{BDL}$ & 10.0 & 50.2 & 453 & 82.5 & 0.80 & 23.6 & 10.7 \\
\hline $7 \mathrm{H}-1,55$ & 50.05 & 57.00 & 7.43 & 2.78 & ND & ND & $\mathrm{NL}$ & ND & NL & ND & 0.22 & $\mathrm{BDL}$ & 10.1 & 50.7 & 453 & 80.9 & 0.80 & 22.9 & 10.9 \\
\hline $6 \mathrm{H}-4,55$ & 50.55 & 54.00 & 7.45 & 2.83 & ND & ND & ND & $\mathrm{ND}$ & ND & ND & 0.27 & $\mathrm{BDL}$ & 9.8 & 49.4 & 446 & 80.8 & 0.81 & 23.0 & 10.8 \\
\hline $7 \mathrm{H}-1,130$ & 50.80 & 57.75 & 7.47 & 2.88 & ND & ND & ND & ND & ND & ND & $\mathrm{BDL}$ & $\mathrm{BDL}$ & 10.1 & 50.8 & 434 & 78.3 & 0.78 & 22.5 & 10.7 \\
\hline $6 \mathrm{H}-4,130$ & 51.30 & 54.75 & 7.47 & 2.96 & ND & ND & ND & ND & ND & ND & 0.22 & $\mathrm{BDL}$ & 10.0 & 50.1 & 443 & 76.6 & 0.77 & 22.7 & 10.9 \\
\hline $7 \mathrm{H}-2,55$ & 51.55 & 58.50 & 7.45 & 2.79 & ND & ND & ND & ND & ND & ND & $\mathrm{BDL}$ & $\mathrm{BDL}$ & 10.2 & 50.2 & 508 & 86.2 & 0.87 & 24.1 & 10.8 \\
\hline $6 \mathrm{H}-5,55$ & 52.05 & 55.50 & 7.46 & 2.87 & ND & ND & ND & ND & ND & ND & $\mathrm{BDL}$ & $\mathrm{BDL}$ & 9.9 & 50.1 & 456 & 81.5 & 0.80 & 23.5 & 10.7 \\
\hline $7 \mathrm{H}-2,130$ & 52.30 & 59.25 & 7.48 & 2.78 & ND & ND & ND & ND & ND & ND & 0.24 & $\mathrm{BDL}$ & 9.9 & 48.7 & 457 & 80.4 & 0.80 & 22.7 & 10.5 \\
\hline $6 \mathrm{H}-5,115$ & 52.65 & 56.10 & 7.51 & 2.7 & ND & ND & $\mathrm{NL}$ & $\mathrm{NL}$ & NL & ND & $\mathrm{BDL}$ & $\mathrm{BDL}$ & 10.0 & 50.6 & 456 & 81.7 & 0.82 & 23.5 & 10.8 \\
\hline $7 \mathrm{H}-3,55$ & 53.05 & 60.00 & 7.44 & 2.56 & ND & ND & ND & ND & ND & ND & $\mathrm{BDL}$ & $\mathrm{BDL}$ & 10.1 & 50.9 & 480 & 81.8 & 0.82 & 23.2 & 10.8 \\
\hline $7 \mathrm{H}-3,130$ & 53.80 & 60.75 & 7.55 & 2.83 & ND & ND & ND & ND & ND & ND & 0.26 & $\mathrm{BDL}$ & 10.2 & 51.0 & 450 & 81.8 & 0.81 & 22.9 & 10.7 \\
\hline $7 \mathrm{H}-4,55$ & 54.55 & 61.50 & ND & ND & ND & ND & $\mathrm{NL}$ & $\mathrm{NL}$ & $\mathrm{NI}$ & $\mathrm{NL}$ & 0.26 & $\mathrm{BD}$ & 10.2 & 51.2 & 443 & 81.5 & 0.80 & 22.6 & 10.5 \\
\hline $7 \mathrm{H}-4,130$ & 55.30 & 62.25 & 7.38 & 2.85 & ND & ND & ND & ND & ND & ND & $\mathrm{BDL}$ & $\mathrm{BDL}$ & 10.3 & 51.2 & 443 & 81.2 & 0.83 & 23.0 & 10.6 \\
\hline $7 \mathrm{H}-5,55$ & 56.05 & 63.00 & 7.38 & 3.02 & ND & ND & ND & ND & ND & ND & $\mathrm{BDL}$ & $\mathrm{BDL}$ & 10.2 & 50.6 & 444 & 83.0 & 0.84 & 23.2 & 10.7 \\
\hline $7 \mathrm{H}-5,130$ & 56.80 & 63.75 & 7.36 & 2.89 & ND & ND & $\mathrm{NL}$ & $\mathrm{NL}$ & $\mathrm{NL}$ & ND & 0.4 & $\mathrm{BDL}$ & 10.2 & 50.3 & 431 & 79.2 & 0.82 & 21.9 & 10.6 \\
\hline $7 \mathrm{H}-6,55$ & 57.55 & 64.50 & 7.31 & 2.99 & ND & ND & ND & ND & ND & ND & 0.29 & $\mathrm{BDL}$ & 10.3 & 51.1 & 433 & 80.8 & 0.78 & 22.1 & 10.7 \\
\hline $7 \mathrm{H}-6,130$ & 58.30 & 65.25 & ND & ND & ND & ND & ND & ND & ND & ND & 0.24 & $\mathrm{BDL}$ & 10.2 & 50.8 & 440 & 80.4 & 0.81 & 22.2 & 10.7 \\
\hline
\end{tabular}

Notes: $\mathrm{ND}=$ not determined. $\mathrm{BDL}=$ below detection limit $\left(\mathrm{Mn}^{2+}=0.2 \mu \mathrm{M}, \mathrm{Fe}^{2+}=0.5 \mu \mathrm{M}, \mathrm{B}=4 \mu \mathrm{M}, \mathrm{Sr}^{2+}=0.6 \mu \mathrm{M}, \mathrm{Ba}^{2+}=0.1 \mu \mathrm{M}, \mathrm{Li}^{+}=1 \mu \mathrm{M}\right)$ calculated as three times the standard deviation of multiple measures of a blank. $\mathrm{H}_{4} \mathrm{SiO}_{4}$ values measured by different techniques during Expeditions 320 and 321 disagree significantly, especially for low values. Therefore, caution should 
Table T28. Inorganic geochemistry of solid samples, Hole U1332A. (See table notes.)

\begin{tabular}{|c|c|c|c|c|c|c|c|c|c|c|c|c|c|c|c|c|c|c|c|}
\hline \multirow{2}{*}{$\begin{array}{l}\text { Core, section, } \\
\text { interval }(\mathrm{cm})\end{array}$} & \multirow{2}{*}{$\begin{array}{c}\text { Depth } \\
\text { CSF (m) }\end{array}$} & \multicolumn{10}{|c|}{ Major element oxide (wt\%) } & \multicolumn{8}{|c|}{ Trace element (ppm) } \\
\hline & & $\mathrm{SiO}_{2}$ & $\mathrm{Al}_{2} \mathrm{O}_{3}$ & $\mathrm{Fe}_{2} \mathrm{O}_{3} \mathrm{~T}$ & $\mathrm{MnO}$ & $\mathrm{MgO}$ & $\mathrm{CaO}$ & $\mathrm{Na}_{2} \mathrm{O}$ & $\mathrm{K}_{2} \mathrm{O}$ & $\mathrm{TiO}_{2}$ & $\mathrm{P}_{2} \mathrm{O}_{5}$ & $\mathrm{Ba}$ & $\mathrm{Cr}$ & $\mathrm{Cu}$ & $\mathrm{Sc}$ & $\mathrm{Sr}$ & V & $Y$ & $\mathrm{Zr}$ \\
\hline \multicolumn{20}{|l|}{ 320-U1332A- } \\
\hline $1 \mathrm{H}-3,25-26$ & 3.25 & 53.62 & 12.89 & 6.57 & 0.06 & 3.37 & 1.00 & 4.67 & 2.43 & 0.62 & 0.42 & 3230 & 54.8 & 772 & 29.8 & 212.5 & 86.9 & 189.3 & 204.9 \\
\hline $3 \mathrm{H}-4,65-66$ & 18.55 & 59.20 & 8.57 & 4.62 & 0.86 & 2.97 & 7.37 & 5.22 & 1.59 & 0.37 & 0.89 & 4719 & 23.9 & 693 & 29.6 & 504.1 & 51.7 & 244.4 & 160.8 \\
\hline $4 \mathrm{H}-6,65-66$ & 31.05 & 50.71 & 5.78 & 3.04 & 0.59 & 2.09 & 16.85 & 4.30 & 1.21 & 0.25 & 0.77 & 3992 & 15.9 & 382 & 18.8 & 803 & 28.3 & 168.5 & 112.4 \\
\hline $5 \mathrm{H}-4,65-66$ & 37.55 & 19.04 & 2.74 & 1.36 & 0.27 & 1.00 & 36.62 & 2.14 & 0.68 & 0.12 & 0.41 & 1691 & 6.6 & 173 & 7.2 & 1744 & 9.1 & 74.2 & 56.2 \\
\hline $7 \mathrm{H}-4,64-65$ & 56.54 & 12.09 & 0.45 & 0.40 & 0.03 & 0.31 & 39.14 & 1.45 & 0.24 & 0.01 & $\mathrm{BDL}$ & 885 & 20.9 & 53 & 1.4 & 1811 & $\mathrm{BDL}$ & 16.4 & 20.2 \\
\hline $9 \mathrm{H}-2,65-66$ & 72.55 & 27.47 & 1.95 & 1.22 & 0.19 & 0.77 & 30.57 & 2.06 & 0.54 & 0.08 & 0.34 & 1216 & 7.6 & 145 & 5.9 & 1360 & 7.9 & 44.8 & 44.9 \\
\hline $10 \mathrm{H}-1,74-75$ & 80.64 & 66.46 & 5.62 & 4.10 & 0.51 & 2.18 & 1.25 & 4.45 & 1.09 & 0.25 & 0.50 & 2990 & 20.4 & 398 & 17.0 & 171.7 & 37.7 & 110.7 & 104.1 \\
\hline $12 \mathrm{H}-6,65-66$ & 107.05 & 74.34 & 1.09 & 2.63 & 0.46 & 1.41 & 0.43 & 3.29 & 0.44 & 0.05 & 0.18 & 1042 & 6.2 & 200 & 4.1 & 59.6 & 33.7 & 28.4 & 35.3 \\
\hline $13 \mathrm{H}-6,65-66$ & 116.55 & 40.26 & 0.79 & 2.03 & 0.43 & 1.16 & 25.98 & 2.13 & 0.33 & 0.04 & 0.24 & 1433 & 6.1 & 220 & 2.9 & 855 & 10.3 & 37.1 & 31.4 \\
\hline $14 \mathrm{H}-3,64-65$ & 121.54 & 70.74 & 1.69 & 4.70 & 0.83 & 2.16 & 0.68 & 3.36 & 0.58 & 0.08 & 0.28 & 1727 & 5.3 & 334 & 7.0 & 90.9 & 34.4 & 61.7 & 52.0 \\
\hline $15 X-4,64-65$ & 131.04 & 74.94 & 0.62 & 2.16 & 0.55 & 1.34 & 1.03 & 3.26 & 0.35 & 0.03 & 0.19 & 2427 & $\mathrm{BDL}$ & 213 & 3.5 & 108.5 & 19.9 & 28.8 & 28.1 \\
\hline $17 X-2,50-51$ & 146.33 & 41.02 & 3.60 & 27.43 & 21.14 & 5.25 & 2.66 & 8.98 & 1.67 & 0.22 & 1.35 & 4093 & 22.7 & 1847 & 14.8 & 455.6 & 404.2 & 224.8 & 108.6 \\
\hline
\end{tabular}

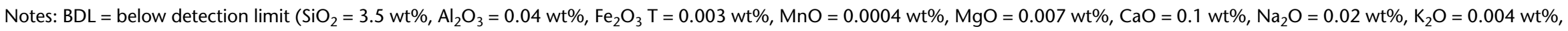
$\left.\mathrm{TiO}_{2}=0.001 \mathrm{wt} \%, \mathrm{P}_{2} \mathrm{O}_{5}=0.1 \mathrm{wt} \%, \mathrm{Ba}=28 \mathrm{wt} \%, \mathrm{Cr}=5 \mathrm{wt} \%, \mathrm{Cu}=16 \mathrm{wt} \%, \mathrm{Sc}=0.4 \mathrm{wt} \%, \mathrm{Sr}=3 \mathrm{wt} \%, \mathrm{~V}=4 \mathrm{wt} \%, \mathrm{Y}=1.7 \mathrm{wt} \%, \mathrm{Zr}=4 \mathrm{wt} \%\right)$. See Table T9 in "Methods" for maximum values of calibration. 
Table T29. Calcium carbonate and organic carbon data, Site U1332. (See table notes.)

\begin{tabular}{|c|c|c|c|c|c|c|}
\hline \multirow{2}{*}{$\begin{array}{l}\text { Core, section, } \\
\text { interval }(\mathrm{cm})\end{array}$} & \multirow{2}{*}{$\begin{array}{l}\text { Depth } \\
\text { CSF }(m)\end{array}$} & \multirow{2}{*}{$\begin{array}{l}\mathrm{CaCO}_{3} \\
(\mathrm{wt} \%)\end{array}$} & \multirow{2}{*}{$\begin{array}{c}\mathrm{IC} \\
(w t \%)\end{array}$} & \multirow{2}{*}{$\begin{array}{c}\text { TC } \\
\text { (wt\%) }\end{array}$} & \multicolumn{2}{|c|}{ TOC (wt\%) } \\
\hline & & & & & Normal & Acid \\
\hline \multicolumn{7}{|l|}{$320-U 1332 A-$} \\
\hline $1 \mathrm{H}-1,64-65$ & 0.64 & BDL & BDL & 0.17 & $\mathrm{BDL}$ & 0.18 \\
\hline $1 \mathrm{H}-2,65-66$ & 2.15 & BDL & BDL & 0.80 & BDL & 0.17 \\
\hline $1 \mathrm{H}-3,25-26$ & 3.25 & BDL & BDL & 0.18 & BDL & ND \\
\hline $2 \mathrm{H}-1,64-65$ & 4.54 & BDL & BDL & 0.07 & $\mathrm{BDL}$ & ND \\
\hline $2 \mathrm{H}-2,65-66$ & 6.05 & BDL & BDL & 0.18 & BDL & 0.03 \\
\hline $2 \mathrm{H}-3,65-66$ & 7.55 & BDL & BDL & 0.17 & BDL & ND \\
\hline $2 \mathrm{H}-4,65-66$ & 9.05 & $\mathrm{BDL}$ & BDL & 0.24 & $\mathrm{BDL}$ & ND \\
\hline $2 \mathrm{H}-5,65-66$ & 10.55 & $\mathrm{BDL}$ & BDL & 0.13 & $\mathrm{BDL}$ & ND \\
\hline $2 \mathrm{H}-6,65-66$ & 12.05 & $\mathrm{BDL}$ & $\mathrm{BDL}$ & 0.06 & $\mathrm{BDL}$ & 0.07 \\
\hline $2 \mathrm{H}-7,20-21$ & 13.10 & BDL & BDL & 0.06 & BDL & ND \\
\hline $3 \mathrm{H}-2,65-66$ & 15.55 & BDL & BDL & 0.03 & BDL & ND \\
\hline $3 \mathrm{H}-3,65-66$ & 17.05 & BDL & BDL & 1.01 & $\mathrm{BDL}$ & ND \\
\hline $3 \mathrm{H}-4,65-66$ & 18.55 & 9.1 & 1.09 & 0.07 & $\mathrm{BDL}$ & 0.07 \\
\hline $3 \mathrm{H}-4,65-66$ & 18.55 & 9.3 & 1.12 & ND & $\mathrm{BDL}$ & ND \\
\hline $3 \mathrm{H}-4,65-66$ & 18.55 & 9.6 & 1.15 & ND & $\mathrm{BDL}$ & ND \\
\hline $3 \mathrm{H}-4,65-66$ & 18.55 & 9.0 & 1.08 & ND & BDL & ND \\
\hline $3 \mathrm{H}-5,65-66$ & 20.05 & 25.2 & 3.03 & 2.95 & BDL & ND \\
\hline $3 \mathrm{H}-6,65-66$ & 21.55 & $\mathrm{BDL}$ & BDL & 0.46 & BDL & 0.07 \\
\hline $3 \mathrm{H}-7,45-46$ & 22.85 & 70.2 & 8.42 & 8.19 & BDL & ND \\
\hline $4 \mathrm{H}-1,65-66$ & 23.55 & 15.8 & 1.90 & 1.71 & BDL & BDL \\
\hline $4 \mathrm{H}-2,60-61$ & 25.00 & 28.5 & 3.42 & 3.35 & $\mathrm{BDL}$ & ND \\
\hline $4 \mathrm{H}-3,65-66$ & 26.55 & 46.6 & 5.59 & 5.71 & 0.12 & ND \\
\hline $4 \mathrm{H}-4,65-66$ & 28.05 & 16.9 & 2.03 & ND & ND & ND \\
\hline $4 \mathrm{H}-5,65-66$ & 29.55 & BDL & BDL & 0.07 & BDL & 0.05 \\
\hline $4 \mathrm{H}-6,65-66$ & 31.05 & 22.4 & 2.69 & ND & ND & ND \\
\hline $4 \mathrm{H}-7,65-66$ & 32.55 & 53.1 & 6.38 & 1.47 & $\mathrm{BDL}$ & ND \\
\hline $5 \mathrm{H}-1,65-66$ & 33.05 & 61.8 & 7.42 & 7.33 & BDL & 0.09 \\
\hline $5 \mathrm{H}-2,65-66$ & 34.55 & 67.2 & 8.06 & 7.96 & $\mathrm{BDL}$ & ND \\
\hline $5 \mathrm{H}-3,65-66$ & 36.05 & 65.4 & 7.85 & 7.87 & 0.01 & ND \\
\hline $5 \mathrm{H}-4,65-66$ & 37.55 & 67.3 & 8.08 & 8.08 & $\mathrm{BDL}$ & ND \\
\hline $5 \mathrm{H}-5,65-66$ & 39.05 & 81.8 & 9.82 & 9.77 & BDL & ND \\
\hline $5 \mathrm{H}-6,65-66$ & 40.55 & 81.2 & 9.75 & 9.68 & BDL & $\mathrm{BDL}$ \\
\hline $5 \mathrm{H}-7,49-50$ & 41.89 & 89.7 & 10.77 & 10.82 & 0.05 & ND \\
\hline $6 \mathrm{H}-1,65-66$ & 42.55 & 89.0 & 10.69 & 10.90 & 0.21 & 0.12 \\
\hline $6 \mathrm{H}-2,65-66$ & 44.05 & 86.9 & 10.43 & ND & ND & ND \\
\hline $6 \mathrm{H}-3,65-66$ & 45.55 & 86.1 & 10.34 & ND & ND & ND \\
\hline $6 \mathrm{H}-4,65-66$ & 47.05 & 85.1 & 10.22 & 10.39 & 0.18 & 0.03 \\
\hline $6 \mathrm{H}-5,65-66$ & 48.55 & 82.8 & 9.94 & ND & ND & ND \\
\hline $6 \mathrm{H}-6,65-66$ & 50.05 & 87.3 & 10.48 & 10.70 & 0.22 & ND \\
\hline $6 \mathrm{H}-6,65-66$ & 50.05 & 87.4 & 10.49 & 10.65 & 0.16 & ND \\
\hline $6 \mathrm{H}-6,65-66$ & 50.05 & 87.1 & 10.45 & 10.69 & 0.24 & ND \\
\hline $6 \mathrm{H}-6,65-66$ & 50.05 & 87.6 & 10.52 & 10.73 & 0.21 & ND \\
\hline $6 \mathrm{H}-6,65-66$ & 50.05 & 86.9 & 10.43 & 10.71 & 0.28 & ND \\
\hline $6 \mathrm{H}-7,24-25$ & 51.14 & 70.6 & 8.47 & ND & ND & ND \\
\hline $7 \mathrm{H}-1,64-65$ & 52.04 & 48.1 & 5.78 & ND & ND & ND \\
\hline $7 \mathrm{H}-2,64-65$ & 53.54 & 78.0 & 9.36 & 9.37 & 0.00 & 0.07 \\
\hline $7 \mathrm{H}-3,64-65$ & 55.04 & 79.5 & 9.55 & 9.84 & 0.29 & ND \\
\hline $7 \mathrm{H}-4,64-65$ & 56.54 & 80.9 & 9.71 & 9.66 & BDL & ND \\
\hline 7H-5, 64-65 & 58.04 & 86.7 & 10.40 & 10.24 & $\mathrm{BDL}$ & $\mathrm{BDL}$ \\
\hline 7H-6, 64-65 & 59.54 & 83.8 & 10.06 & 10.32 & 0.27 & ND \\
\hline $7 \mathrm{H}-7,24-25$ & 60.64 & 80.0 & 9.61 & 9.62 & 0.02 & ND \\
\hline $8 \mathrm{H}-2,100-101$ & 63.40 & 66.0 & 7.93 & ND & ND & ND \\
\hline $8 \mathrm{H}-3,100-101$ & 64.90 & 70.9 & 8.51 & 8.95 & 0.44 & 0.03 \\
\hline $8 \mathrm{H}-4,100-101$ & 66.40 & 73.5 & 8.83 & ND & ND & ND \\
\hline $8 \mathrm{H}-5,100-101$ & 67.90 & 66.0 & 7.92 & ND & ND & ND \\
\hline $8 \mathrm{H}-6,100-101$ & 69.40 & 86.7 & 10.41 & ND & ND & ND \\
\hline $8 \mathrm{H}-7,55-56$ & 70.45 & 83.7 & 10.05 & ND & ND & ND \\
\hline
\end{tabular}

\begin{tabular}{|c|c|c|c|c|c|c|}
\hline \multirow{2}{*}{$\begin{array}{l}\text { Core, section, } \\
\text { interval }(\mathrm{cm})\end{array}$} & \multirow{2}{*}{$\begin{array}{l}\text { Depth } \\
\text { CSF }(m)\end{array}$} & \multirow{2}{*}{$\begin{array}{l}\mathrm{CaCO}_{3} \\
\text { (wt\%) }\end{array}$} & \multirow{2}{*}{$\begin{array}{c}\text { IC } \\
\text { (wt\%) }\end{array}$} & \multirow{2}{*}{$\begin{array}{c}\text { TC } \\
\text { (wt\%) }\end{array}$} & \multicolumn{2}{|c|}{ TOC (wt\%) } \\
\hline & & & & & Normal & Acid \\
\hline $9 \mathrm{H}-1,65-66$ & 71.05 & 61.0 & 7.32 & ND & ND & ND \\
\hline $9 \mathrm{H}-2,65-66$ & 72.55 & 60.2 & 7.23 & ND & ND & ND \\
\hline $9 \mathrm{H}-3,65-66$ & 74.05 & 85.2 & 10.23 & 10.59 & 0.36 & 0.14 \\
\hline $9 \mathrm{H}-4,65-66$ & 75.55 & 15.8 & 1.90 & ND & ND & ND \\
\hline $9 \mathrm{H}-5,65-66$ & 77.05 & BDL & BDL & 0.03 & BDL & ND \\
\hline $9 \mathrm{H}-6,65-66$ & 78.55 & BDL & BDL & 0.05 & $\mathrm{BDL}$ & ND \\
\hline $9 \mathrm{H}-7,25-26$ & 79.65 & BDL & BDL & 0.06 & BDL & 0.05 \\
\hline $9 \mathrm{H}-7,25-26$ & 79.65 & BDL & $\mathrm{BDL}$ & ND & ND & ND \\
\hline $9 \mathrm{H}-7,25-26$ & 79.65 & BDL & $\mathrm{BDL}$ & ND & ND & ND \\
\hline $10 \mathrm{H}-1,74-75$ & 80.64 & BDL & $\mathrm{BDL}$ & 0.51 & $\mathrm{BDL}$ & 0.05 \\
\hline $10 \mathrm{H}-2,64-65$ & 82.04 & BDL & BDL & 0.05 & BDL & ND \\
\hline $10 \mathrm{H}-3,64-65$ & 83.54 & 6.1 & 0.73 & 0.38 & $\mathrm{BDL}$ & ND \\
\hline $10 \mathrm{H}-4,64-65$ & 85.04 & 7.6 & 0.92 & ND & ND & ND \\
\hline $10 \mathrm{H}-5,64-65$ & 86.54 & BDL & BDL & 0.87 & $\mathrm{BDL}$ & 0.06 \\
\hline $10 \mathrm{H}-6,64-65$ & 88.04 & BDL & BDL & 0.07 & $\mathrm{BDL}$ & ND \\
\hline $10 \mathrm{H}-7,29-30$ & 89.19 & BDL & $\mathrm{BDL}$ & 0.05 & $\mathrm{BDL}$ & ND \\
\hline $11 \mathrm{H}-2,65-66$ & 91.55 & BDL & BDL & 0.06 & $\mathrm{BDL}$ & 0.05 \\
\hline $11 \mathrm{H}-3,65-66$ & 93.05 & 3.5 & 0.42 & 0.36 & BDL & ND \\
\hline $11 \mathrm{H}-4,65-66$ & 94.55 & BDL & BDL & 0.06 & $\mathrm{BDL}$ & ND \\
\hline $11 \mathrm{H}-5,65-66$ & 96.05 & 6.6 & 0.80 & 0.84 & 0.05 & 0.06 \\
\hline $11 \mathrm{H}-6,65-66$ & 97.55 & 38.2 & 4.59 & ND & ND & ND \\
\hline $12 \mathrm{H}-2,64-65$ & 101.04 & 2.5 & 0.30 & 0.34 & 0.04 & ND \\
\hline $12 \mathrm{H}-3,65-66$ & 102.55 & BDL & BDL & 0.03 & $\mathrm{BDL}$ & $\mathrm{BDL}$ \\
\hline $12 \mathrm{H}-4,65-66$ & 104.05 & BDL & $\mathrm{BDL}$ & BDL & $\mathrm{BDL}$ & ND \\
\hline $12 \mathrm{H}-5,65-66$ & 105.55 & BDL & BDL & 0.30 & BDL & ND \\
\hline $12 \mathrm{H}-6,65-66$ & 107.05 & BDL & BDL & 0.14 & $\mathrm{BDL}$ & $\mathrm{BDL}$ \\
\hline $13 \mathrm{H}-1,65-66$ & 109.05 & BDL & $\mathrm{BDL}$ & BDL & $\mathrm{BDL}$ & ND \\
\hline $13 \mathrm{H}-2,65-66$ & 110.55 & 14.3 & 1.72 & 1.50 & $\mathrm{BDL}$ & 0.04 \\
\hline $13 \mathrm{H}-3,65-66$ & 112.05 & 43.7 & 5.25 & 6.85 & 1.60 & ND \\
\hline $13 \mathrm{H}-4,65-66$ & 113.55 & 47.7 & 5.73 & BDL & BDL & ND \\
\hline $13 \mathrm{H}-5,65-66$ & 115.05 & 59.7 & 7.16 & 0.53 & $\mathrm{BDL}$ & ND \\
\hline $13 \mathrm{H}-6,65-66$ & 116.55 & 45.7 & 5.49 & ND & ND & ND \\
\hline $13 \mathrm{H}-7,55-56$ & 117.95 & 44.4 & 5.33 & ND & ND & ND \\
\hline $14 \mathrm{H}-2,64-65$ & 120.04 & 27.1 & 3.25 & ND & ND & ND \\
\hline $14 \mathrm{H}-3,64-65$ & 121.54 & $\mathrm{BDL}$ & $\mathrm{BDL}$ & $\mathrm{BDL}$ & $\mathrm{BDL}$ & $\mathrm{BDL}$ \\
\hline $14 \mathrm{H}-4,64-65$ & 123.04 & 14.1 & 1.69 & ND & ND & ND \\
\hline $14 \mathrm{H}-5,64-65$ & 124.54 & 6.4 & 0.77 & 0.23 & BDL & 0.04 \\
\hline $14 \mathrm{H}-6,9-10$ & 125.49 & 19.1 & 2.30 & ND & ND & ND \\
\hline $15 X-1,84-85$ & 126.74 & 12.5 & 1.51 & ND & ND & ND \\
\hline $15 X-2,64-65$ & 128.04 & 10.0 & 1.20 & ND & ND & ND \\
\hline $15 X-3,64-65$ & 129.54 & 57.9 & 6.95 & ND & ND & ND \\
\hline $15 X-4,64-65$ & 131.04 & 1.2 & 0.15 & 0.25 & 0.10 & ND \\
\hline $15 X-5,23-24$ & 132.13 & 5.2 & 0.63 & 0.53 & 0.04 & 0.04 \\
\hline $16 \mathrm{X}-1,65-66$ & 136.15 & BDL & BDL & BDL & BDL & $\mathrm{BDL}$ \\
\hline $16 X-2,65-66$ & 137.65 & 18.7 & 2.24 & 2.38 & 0.14 & ND \\
\hline $17 X-1,50-51$ & 145.00 & BDL & BDL & BDL & BDL & $\mathrm{BDL}$ \\
\hline $17 X-1,60-61$ & 145.10 & BDL & BDL & 0.05 & $\mathrm{BDL}$ & ND \\
\hline $17 X-2,50-51$ & 146.33 & $\mathrm{BDL}$ & $\mathrm{BDL}$ & 0.06 & $\mathrm{BDL}$ & 0.04 \\
\hline $17 X-2,50-51$ & 146.33 & BDL & BDL & 0.15 & $\mathrm{BDL}$ & ND \\
\hline $17 X-2,50-51$ & 146.33 & BDL & $\mathrm{BDL}$ & ND & ND & ND \\
\hline $17 X-2,50-51$ & 146.33 & BDL & BDL & ND & ND & ND \\
\hline $17 X-2,50-51$ & 146.33 & BDL & BDL & ND & ND & ND \\
\hline $17 X-2,60-61$ & 146.43 & BDL & BDL & ND & ND & ND \\
\hline \multicolumn{7}{|l|}{ 320-U1332B- } \\
\hline & 144.65 & B & BDL & 0.10 & BDL & ND \\
\hline $18 X-2,30-31$ & 145.70 & BDL & $\mathrm{BDL}$ & 0.08 & $\mathrm{BDL}$ & ND \\
\hline
\end{tabular}

Notes: $\mathrm{IC}=$ inorganic carbon, $\mathrm{TC}=$ total carbon, $\mathrm{TOC}=$ total organic carbon, $\mathrm{Acid}=$ determined by acidification method. $\mathrm{BDL}=$ below detection limit $\left(\mathrm{CaCO}_{3}=<1 \mathrm{wt} \%\right.$, TOC by either method $\left.=<0.03 \mathrm{wt} \%\right)$ as determined by three times the standard deviation of replicate measures of a low concentration sample. When $\mathrm{CaCO}_{3}$ is $\mathrm{BDL}, \mathrm{TOC}$ is reported as equal to TC. ND = not determined (negative TOC wt\%). 
Table T30. Moisture and density measurements, Site U1332.

\begin{tabular}{|c|c|c|c|c|c|c|}
\hline \multirow[b]{2}{*}{$\begin{array}{l}\text { Core, section, } \\
\text { interval }(\mathrm{cm})\end{array}$} & \multirow[b]{2}{*}{$\begin{array}{l}\text { Depth } \\
\text { CSF }(\mathrm{m})\end{array}$} & \multirow{2}{*}{$\begin{array}{c}\text { Water } \\
\text { content } \\
(\%)\end{array}$} & \multicolumn{3}{|c|}{ Density $\left(\mathrm{g} / \mathrm{cm}^{3}\right)$} & \multirow[b]{2}{*}{$\begin{array}{c}\text { Porosity } \\
\text { (\%) }\end{array}$} \\
\hline & & & $\begin{array}{l}\text { Wet } \\
\text { bulk }\end{array}$ & $\begin{array}{l}\text { Dry } \\
\text { bulk }\end{array}$ & Grain & \\
\hline \multicolumn{7}{|l|}{ 320-U1332A- } \\
\hline $1 \mathrm{H}-1,75-76$ & 0.75 & 73.3 & 1.24 & 0.33 & 2.97 & 88.8 \\
\hline $1 \mathrm{H}-2,75-76$ & 2.25 & 71.3 & 1.24 & 0.36 & 2.67 & 86.6 \\
\hline $1 \mathrm{H}-3,75-76$ & 3.75 & 77.9 & 1.18 & 0.26 & 2.54 & 89.7 \\
\hline $2 \mathrm{H}-1,75-76$ & 4.65 & 73.0 & 1.24 & 0.34 & 2.94 & 88.6 \\
\hline $2 \mathrm{H}-2,75-76$ & 6.15 & 73.7 & 1.20 & 0.32 & 2.39 & 86.8 \\
\hline $2 \mathrm{H}-3,75-76$ & 7.65 & 70.1 & 1.26 & 0.38 & 2.80 & 86.5 \\
\hline $2 \mathrm{H}-4,75-76$ & 9.15 & 64.7 & 1.25 & 0.44 & 2.12 & 79.1 \\
\hline $2 \mathrm{H}-6,75-76$ & 12.15 & 66.3 & 1.28 & 0.43 & 2.58 & 83.2 \\
\hline $2 \mathrm{H}-7,30-31$ & 13.20 & 80.9 & 1.18 & 0.22 & 3.33 & 93.3 \\
\hline $3 \mathrm{H}-1,85-86$ & 14.25 & 81.6 & 1.13 & 0.21 & 2.11 & 90.1 \\
\hline $3 \mathrm{H}-2,75-76$ & 15.65 & 78.6 & 1.18 & 0.25 & 2.71 & 90.7 \\
\hline $3 \mathrm{H}-3,75-76$ & 17.15 & 79.7 & 1.16 & 0.24 & 2.47 & 90.4 \\
\hline $3 \mathrm{H}-4,75-76$ & 18.65 & 76.4 & 1.21 & 0.29 & 2.91 & 90.2 \\
\hline $3 \mathrm{H}-5,75-76$ & 20.15 & 77.3 & 1.15 & 0.26 & 2.00 & 86.9 \\
\hline $4 \mathrm{H}-1,75-76$ & 23.65 & 73.8 & 1.23 & 0.32 & 2.89 & 88.8 \\
\hline $4 \mathrm{H}-3,75-76$ & 26.65 & 74.8 & 1.21 & 0.30 & 2.62 & 88.4 \\
\hline $4 \mathrm{H}-4,75-76$ & 28.15 & 72.0 & 1.23 & 0.34 & 2.50 & 86.3 \\
\hline $4 \mathrm{H}-5,75-76$ & 29.65 & 75.9 & 1.21 & 0.29 & 2.82 & 89.7 \\
\hline $4 \mathrm{H}-7,50-51$ & 32.40 & 51.9 & 1.46 & 0.70 & 2.69 & 73.9 \\
\hline $5 \mathrm{H}-1,75-76$ & 33.15 & 46.8 & 1.52 & 0.81 & 2.66 & 69.6 \\
\hline $5 \mathrm{H}-2,75-76$ & 34.65 & 50.0 & 1.51 & 0.75 & 2.84 & 73.5 \\
\hline $5 \mathrm{H}-3,75-76$ & 36.14 & 44.9 & 1.50 & 0.83 & 2.42 & 65.8 \\
\hline $5 \mathrm{H}-4,75-76$ & 37.64 & 49.3 & 1.51 & 0.77 & 2.80 & 72.7 \\
\hline $5 \mathrm{H}-5,75-76$ & 39.15 & 31.4 & 1.78 & 1.22 & 2.69 & 54.6 \\
\hline $5 \mathrm{H}-6,75-76$ & 40.64 & 44.7 & 1.59 & 0.88 & 2.89 & 69.6 \\
\hline $5 \mathrm{H}-7,60-61$ & 42.00 & 26.0 & 1.90 & 1.40 & 2.71 & 48.2 \\
\hline $6 \mathrm{H}-1,75-76$ & 42.64 & 42.6 & 1.61 & 0.93 & 2.80 & 67.0 \\
\hline $6 \mathrm{H}-2,75-76$ & 44.15 & 40.0 & 1.65 & 0.99 & 2.77 & 64.3 \\
\hline $6 \mathrm{H}-3,75-76$ & 45.65 & 42.8 & 1.65 & 0.95 & 3.06 & 69.1 \\
\hline $6 \mathrm{H}-4,75-76$ & 47.14 & 42.5 & 1.56 & 0.90 & 2.56 & 64.9 \\
\hline $6 \mathrm{H}-5,75-76$ & 48.65 & 37.2 & 1.77 & 1.11 & 3.09 & 64.1 \\
\hline $6 \mathrm{H}-6,75-76$ & 50.15 & 41.4 & 1.64 & 0.96 & 2.84 & 66.2 \\
\hline $6 \mathrm{H}-7,35-36$ & 51.25 & 26.2 & 2.02 & 1.49 & 3.10 & 51.7 \\
\hline $7 \mathrm{H}-1,75-76$ & 52.15 & 54.0 & 1.40 & 0.64 & 2.45 & 73.8 \\
\hline $7 \mathrm{H}-2,75-76$ & 53.64 & 44.6 & 1.60 & 0.88 & 2.92 & 69.7 \\
\hline $7 \mathrm{H}-3,75-76$ & 55.14 & 44.1 & 1.56 & 0.87 & 2.68 & 67.4 \\
\hline $7 \mathrm{H}-4,75-76$ & 56.65 & 41.3 & 1.68 & 0.99 & 3.07 & 67.8 \\
\hline $7 \mathrm{H}-6,75-76$ & 59.65 & 41.1 & 1.63 & 0.96 & 2.76 & 65.3 \\
\hline $7 \mathrm{H}-7,35-36$ & 60.75 & 43.4 & 1.58 & 0.89 & 2.69 & 66.8 \\
\hline $8 \mathrm{H}-2,75-76$ & 63.14 & 51.6 & 1.47 & 0.71 & 2.75 & 74.1 \\
\hline $8 \mathrm{H}-3,75-76$ & 64.65 & 49.8 & 1.45 & 0.73 & 2.46 & 70.4 \\
\hline $8 \mathrm{H}-4,75-76$ & 66.15 & 45.4 & 1.54 & 0.84 & 2.67 & 68.4 \\
\hline $8 \mathrm{H}-6,75-76$ & 69.15 & 41.4 & 1.65 & 0.97 & 2.89 & 66.6 \\
\hline $8 \mathrm{H}-7,35-36$ & 70.25 & 40.7 & 1.60 & 0.95 & 2.60 & 63.6 \\
\hline $9 \mathrm{H}-1,75-76$ & 71.15 & 53.1 & 1.43 & 0.67 & 2.59 & 74.2 \\
\hline
\end{tabular}

\begin{tabular}{|c|c|c|c|c|c|c|}
\hline \multirow[b]{2}{*}{$\begin{array}{l}\text { Core, section, } \\
\text { interval }(\mathrm{cm})\end{array}$} & \multirow[b]{2}{*}{$\begin{array}{l}\text { Depth } \\
\operatorname{CSF}(\mathrm{m})\end{array}$} & \multirow{2}{*}{$\begin{array}{c}\text { Water } \\
\text { content } \\
(\%)\end{array}$} & \multicolumn{3}{|c|}{ Density $\left(\mathrm{g} / \mathrm{cm}^{3}\right)$} & \multirow[b]{2}{*}{$\begin{array}{c}\text { Porosity } \\
\text { (\%) }\end{array}$} \\
\hline & & & $\begin{array}{l}\text { Wet } \\
\text { bulk }\end{array}$ & $\begin{array}{l}\text { Dry } \\
\text { bulk }\end{array}$ & Grain & \\
\hline $9 \mathrm{H}-2,75-76$ & 72.65 & 53.8 & 1.42 & 0.65 & 2.55 & 74.4 \\
\hline $9 \mathrm{H}-3,75-76$ & 74.15 & 40.2 & 1.66 & 1.00 & 2.87 & 65.3 \\
\hline $9 \mathrm{H}-5,75-76$ & 77.15 & 61.8 & 1.31 & 0.50 & 2.35 & 78.8 \\
\hline $9 \mathrm{H}-6,75-76$ & 78.65 & 71.8 & 1.21 & 0.34 & 2.20 & 84.6 \\
\hline $9 \mathrm{H}-7,35-36$ & 79.75 & 70.7 & 1.25 & 0.37 & 2.67 & 86.3 \\
\hline $10 \mathrm{H}-1,85-86$ & 80.75 & 65.7 & 1.31 & 0.45 & 2.88 & 84.4 \\
\hline $10 \mathrm{H}-2,75-76$ & 82.15 & 71.2 & 1.22 & 0.35 & 2.26 & 84.5 \\
\hline $10 \mathrm{H}-3,75-76$ & 83.65 & 69.0 & 1.25 & 0.39 & 2.52 & 84.6 \\
\hline $10 \mathrm{H}-4,75-76$ & 85.15 & 69.1 & 1.22 & 0.38 & 2.13 & 82.3 \\
\hline $10 \mathrm{H}-6,75-76$ & 88.15 & 71.1 & 1.21 & 0.35 & 2.21 & 84.2 \\
\hline $10 \mathrm{H}-7,40-41$ & 89.30 & 71.1 & 1.24 & 0.36 & 2.59 & 86.1 \\
\hline $11 \mathrm{H}-2,75-76$ & 91.65 & 73.6 & 1.18 & 0.31 & 2.08 & 85.0 \\
\hline $11 \mathrm{H}-3,75-76$ & 93.15 & 74.4 & 1.20 & 0.31 & 2.45 & 87.4 \\
\hline $11 \mathrm{H}-4,75-76$ & 94.65 & 71.0 & 1.22 & 0.35 & 2.33 & 84.8 \\
\hline $11 \mathrm{H}-5,75-76$ & 96.15 & 68.7 & 1.27 & 0.40 & 2.69 & 85.2 \\
\hline $11 \mathrm{H}-6,75-76$ & 97.65 & 61.9 & 1.29 & 0.49 & 2.27 & 78.2 \\
\hline $12 \mathrm{H}-2,75-76$ & 101.15 & 70.1 & 1.24 & 0.37 & 2.45 & 84.9 \\
\hline $12 \mathrm{H}-3,75-76$ & 102.65 & 74.3 & 1.19 & 0.31 & 2.22 & 86.2 \\
\hline $12 \mathrm{H}-4,75-76$ & 104.15 & 72.6 & 1.21 & 0.33 & 2.35 & 85.8 \\
\hline $12 \mathrm{H}-5,75-76$ & 105.65 & 71.7 & 1.18 & 0.34 & 1.96 & 82.9 \\
\hline $12 \mathrm{H}-6,75-76$ & 107.15 & 71.4 & 1.23 & 0.35 & 2.45 & 85.6 \\
\hline $12 \mathrm{H}-7,35-36$ & 108.05 & 68.2 & 1.24 & 0.39 & 2.24 & 82.4 \\
\hline $13 \mathrm{H}-1,75-76$ & 109.15 & 72.1 & 1.23 & 0.34 & 2.60 & 86.8 \\
\hline $13 \mathrm{H}-2,75-76$ & 110.65 & 66.1 & 1.24 & 0.42 & 2.14 & 80.3 \\
\hline $13 \mathrm{H}-3,75-76$ & 112.15 & 61.3 & 1.34 & 0.52 & 2.58 & 78.0 \\
\hline $13 \mathrm{H}-4,75-76$ & 113.65 & 55.2 & 1.40 & 0.63 & 2.58 & 75.7 \\
\hline $13 \mathrm{H}-5,75-76$ & 115.15 & 55.8 & 1.42 & 0.63 & 2.80 & 77.5 \\
\hline $13 \mathrm{H}-6,75-76$ & 116.65 & 64.0 & 1.28 & 0.46 & 2.28 & 79.8 \\
\hline $13 \mathrm{H}-7,65-66$ & 118.05 & 58.0 & 1.38 & 0.58 & 2.67 & 78.3 \\
\hline $14 \mathrm{H}-2,75-76$ & 120.15 & 60.0 & 1.33 & 0.53 & 2.42 & 78.0 \\
\hline $14 \mathrm{H}-3,75-76$ & 121.65 & 65.9 & 1.29 & 0.44 & 2.63 & 83.2 \\
\hline $14 \mathrm{H}-4,75-76$ & 123.15 & 63.5 & 1.27 & 0.46 & 2.15 & 78.5 \\
\hline $14 \mathrm{H}-5,75-76$ & 124.65 & 65.1 & 1.26 & 0.44 & 2.26 & 80.4 \\
\hline $15 X-1,75-76$ & 126.65 & 60.5 & 1.36 & 0.54 & 2.76 & 80.5 \\
\hline $15 X-2,75-76$ & 128.15 & 64.5 & 1.27 & 0.45 & 2.23 & 79.8 \\
\hline $15 X-3,75-76$ & 129.65 & 63.5 & 1.30 & 0.48 & 2.47 & 80.8 \\
\hline $15 X-4,75-76$ & 131.15 & 67.7 & 1.28 & 0.41 & 2.63 & 84.3 \\
\hline $15 X-5,30-31$ & 132.20 & 65.9 & 1.23 & 0.42 & 2.03 & 79.3 \\
\hline $16 X-1,75-76$ & 136.25 & 66.4 & 1.27 & 0.43 & 2.47 & 82.7 \\
\hline $16 X-2,75-76$ & 137.75 & 57.3 & 1.33 & 0.57 & 2.22 & 74.4 \\
\hline $17 X-1,85-86$ & 145.35 & 58.5 & 1.45 & 0.60 & 3.57 & 83.1 \\
\hline $17 X-3,95-96$ & 148.20 & 31.3 & 1.74 & 1.20 & 2.56 & 53.2 \\
\hline \multicolumn{7}{|l|}{ 320-U1332B- } \\
\hline $18-X 2,30-31$ & 145.70 & 59.6 & 1.38 & 0.56 & 2.89 & 80.6 \\
\hline
\end{tabular}


Table T31. Split-core $P$-wave velocity measurements, Hole U1332A.

\begin{tabular}{|c|c|c|c|c|c|c|c|c|c|c|c|c|c|c|}
\hline \multirow{2}{*}{$\begin{array}{l}\text { Core, } \\
\text { section }\end{array}$} & \multirow{2}{*}{$\begin{array}{l}\text { Depth } \\
\text { CSF }(m)\end{array}$} & \multicolumn{3}{|c|}{ Velocity $(\mathrm{m} / \mathrm{s})$} & \multirow{2}{*}{$\begin{array}{c}\text { Core, } \\
\text { section }\end{array}$} & \multirow{2}{*}{$\begin{array}{c}\text { Depth } \\
\operatorname{CSF}(m)\end{array}$} & \multicolumn{3}{|c|}{ Velocity $(\mathrm{m} / \mathrm{s})$} & \multirow{2}{*}{$\begin{array}{c}\text { Core, } \\
\text { section }\end{array}$} & \multirow{2}{*}{$\begin{array}{l}\text { Depth } \\
\text { CSF }(m)\end{array}$} & \multicolumn{3}{|c|}{ Velocity $(\mathrm{m} / \mathrm{s})$} \\
\hline & & $x$-axis & $y$-axis & $z$-axis & & & $x$-axis & $y$-axis & $z$-axis & & & $x$-axis & $y$-axis & $z$-axis \\
\hline \multicolumn{5}{|c|}{ 320-U1332A- } & $5 \mathrm{H}-1$ & 33.82 & 1571 & & & $8 \mathrm{H}-3$ & 65.23 & & 1409 & \\
\hline $1 \mathrm{H}-1$ & 1.3 & & 1499 & & $5 \mathrm{H}-2$ & 35.13 & & 1506 & & $8 \mathrm{H}-3$ & 65.31 & 1645 & & \\
\hline $1 \mathrm{H}-1$ & 1.3 & & & 1496 & $5 \mathrm{H}-2$ & 35.13 & & & 1493 & $8 \mathrm{H}-4$ & 66.75 & & & 1455 \\
\hline $1 \mathrm{H}-1$ & 1.21 & 1594 & & & $5 \mathrm{H}-2$ & 35.21 & 1592 & & & $8 \mathrm{H}-4$ & 66.85 & 1600 & & \\
\hline $1 \mathrm{H}-2$ & 2.82 & & 1500 & & $5 \mathrm{H}-3$ & 36.73 & & 1514 & & $8 \mathrm{H}-5$ & 68.32 & & 1505 & \\
\hline $1 \mathrm{H}-2$ & 2.82 & & & 1495 & $5 \mathrm{H}-3$ & 36.73 & & & 1498 & $8 \mathrm{H}-5$ & 68.32 & & & 1452 \\
\hline $1 \mathrm{H}-2$ & 2.89 & 1593 & & & $5 \mathrm{H}-3$ & 36.83 & 1609 & & & $8 \mathrm{H}-5$ & 68.23 & 1588 & & \\
\hline $1 \mathrm{H}-3$ & 3.63 & & 1502 & & $5 \mathrm{H}-4$ & 38.25 & & 1506 & & $8 \mathrm{H}-6$ & 69.77 & & 1522 & \\
\hline $1 \mathrm{H}-3$ & 3.63 & & & 1495 & $5 \mathrm{H}-4$ & 38.25 & & & 1492 & $8 \mathrm{H}-6$ & 69.77 & & & 1505 \\
\hline $1 \mathrm{H}-3$ & 3.54 & 1606 & & & $5 \mathrm{H}-4$ & 38.33 & 1613 & & & $8 \mathrm{H}-6$ & 69.84 & 1625 & & \\
\hline $2 \mathrm{H}-1$ & 5.2 & & 1499 & & $5 \mathrm{H}-5$ & 39.94 & 1605 & & & $8 \mathrm{H}-7$ & 70.61 & & 1535 & \\
\hline $2 \mathrm{H}-1$ & 5.2 & & & 1495 & $5 \mathrm{H}-5$ & 39.7 & & 1505 & & $8 \mathrm{H}-7$ & 70.61 & & & 1514 \\
\hline $2 \mathrm{H}-1$ & 5.31 & 1597 & & & $5 \mathrm{H}-5$ & 39.7 & & & 1498 & $8 \mathrm{H}-7$ & 70.69 & 1634 & & \\
\hline $2 \mathrm{H}-2$ & 6.68 & & 1500 & & $5 \mathrm{H}-6$ & 41.24 & & 1516 & & $10 \mathrm{H}-1$ & 81.26 & & 1550 & \\
\hline $2 \mathrm{H}-2$ & 6.68 & & & 1494 & $5 \mathrm{H}-6$ & 41.24 & & & 1505 & $10 \mathrm{H}-1$ & 81.34 & 1652 & & \\
\hline $2 \mathrm{H}-2$ & 6.77 & 1631 & & & $5 \mathrm{H}-6$ & 41.32 & 1610 & & & $10 \mathrm{H}-2$ & 82.85 & 1669 & & \\
\hline $2 \mathrm{H}-3$ & 8.2 & & 1501 & & $6 \mathrm{H}-1$ & 43.26 & & & 1468 & $10 \mathrm{H}-3$ & 84.28 & 1674 & & \\
\hline $2 \mathrm{H}-3$ & 8.2 & & & 1496 & $6 \mathrm{H}-1$ & 43.34 & 1607 & & & $10 \mathrm{H}-4$ & 85.84 & 1645 & & \\
\hline $2 \mathrm{H}-3$ & 8.28 & 1622 & & & $6 \mathrm{H}-2$ & 44.77 & & 1516 & & $10 \mathrm{H}-5$ & 87.33 & 1650 & & \\
\hline $2 \mathrm{H}-4$ & 9.71 & & 1497 & & $6 \mathrm{H}-2$ & 44.77 & & & 1442 & $10 \mathrm{H}-6$ & 88.74 & & 1454 & \\
\hline $2 \mathrm{H}-4$ & 9.71 & & & 1494 & $6 \mathrm{H}-2$ & 44.85 & 1624 & & & $11 \mathrm{H}-2$ & 92.34 & 1666 & & \\
\hline $2 \mathrm{H}-4$ & 9.8 & 1604 & & & $6 \mathrm{H}-3$ & 46.19 & & & 1456 & $11 \mathrm{H}-3$ & 93.8 & 1689 & & \\
\hline $2 \mathrm{H}-5$ & 11.13 & & 1508 & & $6 \mathrm{H}-3$ & 46.3 & 1592 & & & $11 \mathrm{H}-4$ & 95.23 & & 1457 & \\
\hline $2 \mathrm{H}-5$ & 11.13 & & & 1494 & $6 \mathrm{H}-4$ & 47.78 & & 1512 & & $11 \mathrm{H}-4$ & 95.3 & 1623 & & \\
\hline $2 \mathrm{H}-5$ & 11.21 & 1608 & & & $6 \mathrm{H}-4$ & 47.78 & & & 1498 & $11 \mathrm{H}-5$ & 96.81 & 1604 & & \\
\hline $2 \mathrm{H}-6$ & 12.7 & & 1499 & & $6 \mathrm{H}-4$ & 47.86 & 1606 & & & $11 \mathrm{H}-6$ & 98.11 & & 1444 & \\
\hline $2 \mathrm{H}-6$ & 12.7 & & & 1827 & $6 \mathrm{H}-5$ & 49.21 & & 1530 & & $11 \mathrm{H}-6$ & 98.19 & 1591 & & \\
\hline $2 \mathrm{H}-6$ & 12.79 & 1610 & & & $6 \mathrm{H}-5$ & 49.21 & & & 1520 & $12 \mathrm{H}-2$ & 101.69 & & 1450 & \\
\hline $3 \mathrm{H}-3$ & 17.72 & & 1521 & & $6 \mathrm{H}-5$ & 49.3 & 1628 & & & $12 \mathrm{H}-2$ & 101.82 & 1648 & & \\
\hline $3 \mathrm{H}-3$ & 17.72 & & & 1475 & $6 \mathrm{H}-6$ & 50.77 & & 1512 & & $12 \mathrm{H}-3$ & 103.3 & 1646 & & \\
\hline $3 \mathrm{H}-4$ & 19.73 & 1598 & & & $6 \mathrm{H}-6$ & 50.77 & & & 1503 & $12 \mathrm{H}-4$ & 104.8 & 1627 & & \\
\hline $3 \mathrm{H}-5$ & 20.98 & & 1533 & & $6 \mathrm{H}-6$ & 50.86 & 1615 & & & $12 \mathrm{H}-5$ & 106.22 & 1625 & & \\
\hline $3 \mathrm{H}-5$ & 20.98 & & & 1481 & $6 \mathrm{H}-7$ & 51.55 & & & 1503 & $12 \mathrm{H}-6$ & 107.63 & 1625 & & \\
\hline $3 \mathrm{H}-5$ & 20.75 & 1583 & & & $6 \mathrm{H}-7$ & 51.65 & 1625 & & & $13 \mathrm{H}-1$ & 109.71 & & 1448 & \\
\hline $3 \mathrm{H}-6$ & 22.22 & & 1534 & & $7 \mathrm{H}-1$ & 52.85 & & 1518 & & $13 \mathrm{H}-1$ & 109.81 & 1664 & & \\
\hline $3 \mathrm{H}-6$ & 22.3 & 1611 & & & $7 \mathrm{H}-1$ & 52.85 & & & 1497 & $13 \mathrm{H}-2$ & 111.32 & 1660 & & \\
\hline $4 \mathrm{H}-1$ & 24.2 & & 1530 & & $7 \mathrm{H}-1$ & 52.76 & 1594 & & & $13 \mathrm{H}-3$ & 112.7 & & 1533 & \\
\hline $4 \mathrm{H}-1$ & 24.2 & & & 1472 & $7 \mathrm{H}-2$ & 54.18 & & 1514 & & $13 \mathrm{H}-3$ & 112.79 & 1600 & & \\
\hline $4 \mathrm{H}-1$ & 24.28 & 1584 & & & $7 \mathrm{H}-2$ & 54.18 & & & 1505 & $13 \mathrm{H}-4$ & 114.25 & & 1532 & \\
\hline $4 \mathrm{H}-2$ & 25.64 & & 1444 & & $7 \mathrm{H}-2$ & 54.08 & 1630 & & & $13 \mathrm{H}-4$ & 114.35 & 1605 & & \\
\hline $4 \mathrm{H}-2$ & 25.64 & & & 1523 & $7 \mathrm{H}-3$ & 53.09 & & 1528 & & $13 \mathrm{H}-5$ & 115.73 & & 1551 & \\
\hline $4 \mathrm{H}-2$ & 25.73 & 1601 & & & $7 \mathrm{H}-3$ & 53.09 & & & 1465 & $13 \mathrm{H}-5$ & 115.86 & 1604 & & \\
\hline $4 \mathrm{H}-3$ & 27.2 & & 1439 & & $7 \mathrm{H}-3$ & 55.8 & 1631 & & & $13 \mathrm{H}-6$ & 117.22 & & 1444 & \\
\hline $4 \mathrm{H}-3$ & 27.2 & & & 1517 & $7 \mathrm{H}-4$ & 57.07 & & 1523 & & $13 \mathrm{H}-6$ & 117.33 & 1597 & & \\
\hline $4 \mathrm{H}-3$ & 27.29 & 1592 & & & $7 \mathrm{H}-4$ & 57.23 & 1634 & & & $14 \mathrm{H}-2$ & 120.85 & 1570 & & \\
\hline $4 \mathrm{H}-4$ & 28.74 & & 1530 & & $7 \mathrm{H}-5$ & 58.82 & & 1519 & & $14 \mathrm{H}-3$ & 122.3 & 1595 & & \\
\hline $4 \mathrm{H}-4$ & 28.74 & & & 1511 & $7 \mathrm{H}-5$ & 58.82 & & & 1512 & $14 \mathrm{H}-4$ & 123.86 & 1616 & & \\
\hline $4 \mathrm{H}-4$ & 28.83 & 1595 & & & $7 \mathrm{H}-5$ & 58.68 & 1636 & & & $14 \mathrm{H}-5$ & 125.36 & 1617 & & \\
\hline $4 \mathrm{H}-5$ & 30.19 & & & 1467 & $7 \mathrm{H}-6$ & 60.2 & & 1519 & & $14 \mathrm{H}-6$ & 126.84 & 1607 & & \\
\hline $4 \mathrm{H}-5$ & 30.27 & 1585 & & & $7 \mathrm{H}-6$ & 60.2 & & & 1509 & $15 X-1$ & 127.36 & 1637 & & \\
\hline $4 \mathrm{H}-6$ & 31.74 & & 1509 & & $7 \mathrm{H}-6$ & 60.35 & 1619 & & & $15 X-2$ & 128.85 & 1653 & & \\
\hline $4 \mathrm{H}-6$ & 31.74 & & & 1508 & $7 \mathrm{H}-7$ & 61.15 & & 1521 & & $15 X-3$ & 130.13 & & 1416 & \\
\hline $4 \mathrm{H}-6$ & 31.82 & 1591 & & & $7 \mathrm{H}-7$ & 61.15 & & & 1509 & $15 X-4$ & 131.86 & 1669 & & \\
\hline $5 \mathrm{H}-1$ & 33.74 & & 1499 & & $7 \mathrm{H}-7$ & 61.23 & 1615 & & & $15 X-5$ & 132.78 & 1656 & & \\
\hline $5 \mathrm{H}-1$ & 33.74 & & & 1497 & $8 \mathrm{H}-2$ & 63.84 & 1646 & & & $16 X-1$ & 136.94 & 1652 & & \\
\hline
\end{tabular}


Table T32. Thermal conductivity, Hole U1332A.

\begin{tabular}{lrc}
\hline $\begin{array}{c}\text { Core, section, } \\
\text { interval }(\mathrm{cm})\end{array}$ & $\begin{array}{c}\text { Depth } \\
\text { CSF }(\mathrm{m})\end{array}$ & $\begin{array}{c}\text { Thermal } \\
\text { conductivity } \\
(\mathrm{W} /[\mathrm{m} \cdot \mathrm{K}])\end{array}$ \\
\hline $\begin{array}{l}\text { 320-U1332A- } \\
1 \mathrm{H}-3,60\end{array}$ & 3.60 & 0.804 \\
$2 \mathrm{H}-3,115$ & 8.05 & 0.821 \\
$3 \mathrm{H}-3,115$ & 17.55 & 0.751 \\
$4 \mathrm{H}-3,115$ & 27.05 & 0.788 \\
$5 \mathrm{H}-3,115$ & 36.55 & 1.206 \\
$6 \mathrm{H}-3,115$ & 46.05 & 1.009 \\
$7 \mathrm{H}-3,115$ & 55.55 & 1.156 \\
$8 \mathrm{H}-3,115$ & 65.05 & 1.046 \\
$9 \mathrm{H}-3,115$ & 74.55 & 1.185 \\
$10 \mathrm{H}-3,115$ & 84.05 & 0.810 \\
$12 \mathrm{H}-3,115$ & 103.05 & 0.767 \\
$13 \mathrm{H}-3,115$ & 112.55 & 0.944 \\
$14 \mathrm{H}-3,115$ & 122.05 & 0.804 \\
$15 \mathrm{X}-3,115$ & 130.05 & 0.824 \\
$16 \mathrm{X}-1,115$ & 136.65 & 0.787 \\
$17 \mathrm{X}-2,115$ & 146.98 & 0.621 \\
\hline
\end{tabular}


Table T33. Shipboard core top, composite, and corrected composite depths, Site U1332.

\begin{tabular}{|c|c|c|c|c|}
\hline \multirow[b]{2}{*}{ Core } & \multirow{2}{*}{$\begin{array}{l}\text { Depth } \\
\text { CSF (m) }\end{array}$} & \multirow{2}{*}{$\begin{array}{c}\text { Offset } \\
\text { (m) }\end{array}$} & \multicolumn{2}{|c|}{ Top depth (m) } \\
\hline & & & CCSF-A & CCSF-B \\
\hline \multicolumn{5}{|c|}{ 320-U1332A- } \\
\hline $1 \mathrm{H}$ & 0 & 0.00 & 0.00 & 0.00 \\
\hline $2 \mathrm{H}$ & 3.9 & 0.31 & 4.21 & 3.79 \\
\hline $3 \mathrm{H}$ & 13.4 & 0.65 & 14.05 & 12.65 \\
\hline $4 \mathrm{H}$ & 22.9 & 2.65 & 25.55 & 23.00 \\
\hline $5 \mathrm{H}$ & 32.4 & 5.15 & 37.55 & 33.80 \\
\hline $6 \mathrm{H}$ & 41.9 & 5.65 & 47.55 & 42.80 \\
\hline $7 \mathrm{H}$ & 51.4 & 7.90 & 59.30 & 53.37 \\
\hline $8 \mathrm{H}$ & 60.9 & 7.50 & 68.40 & 61.56 \\
\hline $9 \mathrm{H}$ & 70.4 & 2.78 & 73.18 & 65.86 \\
\hline $10 \mathrm{H}$ & 79.9 & 3.48 & 83.38 & 75.04 \\
\hline $11 \mathrm{H}$ & 89.4 & 3.32 & 92.72 & 83.45 \\
\hline $12 \mathrm{H}$ & 98.9 & 6.02 & 104.92 & 94.43 \\
\hline $13 \mathrm{H}$ & 108.4 & 7.77 & 116.17 & 104.55 \\
\hline $14 \mathrm{H}$ & 117.9 & 11.52 & 129.42 & 116.48 \\
\hline $15 X$ & 125.9 & 12.52 & 138.42 & 124.58 \\
\hline $16 X$ & 135.5 & 12.52 & 148.02 & 133.22 \\
\hline $17 X$ & 144.5 & 12.52 & 157.02 & 141.32 \\
\hline $18 \mathrm{X}$ & 150.4 & 12.52 & 162.92 & 146.63 \\
\hline \multicolumn{5}{|c|}{ 320-U1332B- } \\
\hline $1 \mathrm{H}$ & 0 & 0.15 & 0.15 & 0.14 \\
\hline $2 \mathrm{H}$ & 2.1 & 0.65 & 2.75 & 2.48 \\
\hline $3 \mathrm{H}$ & 11.6 & 2.15 & 13.75 & 12.38 \\
\hline $4 \mathrm{H}$ & 19.6 & 4.25 & 23.85 & 21.47 \\
\hline $5 \mathrm{H}$ & 29.1 & 4.35 & 33.45 & 30.11 \\
\hline $6 \mathrm{H}$ & 38.6 & 7.15 & 45.75 & 41.18 \\
\hline $7 \mathrm{H}$ & 48.1 & 10.50 & 58.60 & 52.74 \\
\hline $8 \mathrm{H}$ & 57.6 & 10.20 & 67.80 & 61.02 \\
\hline $9 \mathrm{H}$ & 67.1 & 3.90 & 71.00 & 63.90 \\
\hline $10 \mathrm{H}$ & 76.6 & 5.60 & 82.20 & 73.98 \\
\hline $11 \mathrm{H}$ & 86.1 & 6.07 & 92.17 & 82.95 \\
\hline $12 \mathrm{H}$ & 91.1 & 9.27 & 100.37 & 90.33 \\
\hline $13 \mathrm{H}$ & 100.6 & 9.72 & 110.32 & 99.29 \\
\hline $14 X$ & 110.1 & 10.67 & 120.77 & 108.69 \\
\hline $15 X$ & 116.1 & 14.92 & 131.02 & 117.92 \\
\hline $16 X$ & 124.6 & 16.95 & 141.55 & 127.40 \\
\hline $17 X$ & 134.3 & 16.95 & 151.25 & 136.13 \\
\hline $18 \mathrm{X}$ & 143.9 & 14.77 & 158.67 & 142.80 \\
\hline \multicolumn{5}{|c|}{ 320-U1332C- } \\
\hline $1 \mathrm{H}$ & 0 & 0.04 & 0.04 & 0.04 \\
\hline $2 \mathrm{H}$ & 7.5 & 0.49 & 7.99 & 7.19 \\
\hline $3 \mathrm{H}$ & 17 & 0.25 & 17.25 & 15.53 \\
\hline $4 \mathrm{H}$ & 26.5 & 2.45 & 28.95 & 26.06 \\
\hline $5 \mathrm{H}$ & 36 & 4.25 & 40.25 & 36.23 \\
\hline $6 \mathrm{H}$ & 45.5 & 3.45 & 48.95 & 44.06 \\
\hline $7 \mathrm{H}$ & 49.5 & 6.95 & 56.45 & 50.81 \\
\hline $8 \mathrm{H}$ & 59 & 7.66 & 66.66 & 59.99 \\
\hline $9 \mathrm{H}$ & 66 & 1.10 & 67.10 & 60.39 \\
\hline $10 \mathrm{H}$ & 75.5 & 0.70 & 76.20 & 68.58 \\
\hline $11 \mathrm{H}$ & 85 & 3.50 & 88.50 & 79.65 \\
\hline $12 \mathrm{H}$ & 94.5 & 4.84 & 99.34 & 89.41 \\
\hline $13 \mathrm{H}$ & 104 & 4.84 & 108.84 & 97.96 \\
\hline $14 X$ & 113.5 & 7.14 & 120.64 & 108.58 \\
\hline $15 X$ & 118 & 9.94 & 127.94 & 115.15 \\
\hline $16 X$ & 127.6 & 10.69 & 138.29 & 124.46 \\
\hline $17 X$ & 137.2 & 10.69 & 147.89 & 133.10 \\
\hline $18 x$ & 146.9 & 12.69 & 159.59 & 143.63 \\
\hline
\end{tabular}


Table T34. Splice tie points, Site U1332.

\begin{tabular}{|c|c|c|c|c|c|c|}
\hline \multirow{2}{*}{$\begin{array}{l}\text { Hole, core, section, } \\
\text { interval }(\mathrm{cm})\end{array}$} & \multicolumn{2}{|c|}{ Depth $(m)$} & & \multirow{2}{*}{$\begin{array}{l}\text { Hole, core, section, } \\
\text { interval }(\mathrm{cm})\end{array}$} & \multicolumn{2}{|c|}{ Depth $(\mathrm{m})$} \\
\hline & CSF & CCSF-A & & & CSF & CCSF-A \\
\hline $320-$ & & & & $320-$ & & \\
\hline U1332A-1H-2, 109 & 2.59 & 2.59 & Tie to & U1332C-1H-2, 104 & 2.54 & 2.59 \\
\hline U1332C-1H-5, 63 & 6.63 & 6.67 & Tie to & U1332A-2H-2, 96 & 6.36 & 6.67 \\
\hline U1332A-2H-5, 126 & 11.16 & 11.47 & Tie to & U1332C-2H-3, 48 & 10.98 & 11.47 \\
\hline U1332C-2H-6, 146 & 16.46 & 16.95 & Tie to & U1332A-3H-2, 140 & 16.30 & 16.95 \\
\hline U1332A-3H-5, 38 & 19.78 & 20.43 & Tie to & U1332C-3H-3, 18 & 20.18 & 20.43 \\
\hline U1332C-3H-7, 17 & 26.17 & 26.42 & Tie to & U1332A-4H-1, 87 & 23.77 & 26.42 \\
\hline U1332A-4H-5, 22 & 29.12 & 31.77 & Tie to & U1332C-4H-2, 132 & 29.32 & 31.77 \\
\hline U1332C-4H-5, 47 & 32.97 & 35.42 & Tie to & U1332B-5H-2, 47 & 31.07 & 35.42 \\
\hline U1332B-5H-5, 152 & 36.62 & 40.97 & Tie to & U1332C-5H-1, 72 & 36.72 & 40.97 \\
\hline U1332C-5H-6, 110 & 44.60 & 48.85 & Tie to & U1332A-6H-1, 130 & 43.20 & 48.85 \\
\hline U1332A-6H-7, 32 & 51.22 & 56.87 & Tie to & U1332C-7H-1, 42 & 49.92 & 56.87 \\
\hline U1332C-7H-7, 28 & 58.78 & 65.73 & Tie to & U1332B-7H-5, 113 & 55.23 & 65.73 \\
\hline U1332B-7H-7, 68 & 57.78 & 68.28 & Tie to & U1332C-8H-2, 11 & 60.62 & 68.28 \\
\hline U1332C-8H-4, 34 & 63.84 & 71.50 & Tie to & U1332B-9H-1, 50 & 67.60 & 71.50 \\
\hline U1332B-9H-5, 35 & 73.45 & 77.35 & Tie to & U1332A-9H-3, 117 & 74.57 & 77.35 \\
\hline U1332A-9H-7, 74 & 80.14 & 82.92 & Tie to & U1332B-10H-1, 72 & 77.32 & 82.92 \\
\hline U1332B-10H-5, 90 & 83.50 & 89.10 & Tie to & U1332A-10H-4, 122 & 85.62 & 89.10 \\
\hline U1332A-10H-6, 110 & 88.50 & 91.98 & Tie to & U1332C-11H-3, 48 & 88.48 & 91.98 \\
\hline U1332C-11H-5, 93 & 91.93 & 95.43 & Tie to & U1332A-11H-2, 121 & 92.11 & 95.43 \\
\hline U1332A-11H-6, 72 & 97.62 & 100.94 & Tie to & U1332C-12H-2, 10 & 96.10 & 100.94 \\
\hline U1332C-12H-5, 89 & 101.39 & 106.23 & Tie to & U1332A-12H-1, 131 & 100.21 & 106.23 \\
\hline U1332A-12H-4, 57 & 103.97 & 109.99 & Tie to & U1332C-13H-1, 115 & 105.15 & 109.99 \\
\hline U1332C-13H-3, 146 & 108.46 & 113.30 & Tie to & U1332B-13H-2, 148 & 103.58 & 113.30 \\
\hline U1332B-13H-6, 44 & 108.54 & 118.26 & Tie to & U1332A-13H-2, 59 & 110.49 & 118.26 \\
\hline U1332A-13H-5, 117 & 115.57 & 123.34 & Tie to & U1332B-14X-2, 107 & 112.67 & 123.34 \\
\hline U1332B-14X-6, 140 & 119.00 & 129.67 & Tie to & U1332C-15X-2, 23 & 119.73 & 129.67 \\
\hline U1332C-15X-5, 4 & 124.04 & 133.98 & Tie to & U1332B-15X-2, 146 & 119.06 & 133.98 \\
\hline
\end{tabular}


Table T35. Magnetostratigraphic and biostratigraphic datums, Site U1332. (See table note.)

\begin{tabular}{|c|c|c|c|c|c|c|c|}
\hline Event & $\begin{array}{l}\text { Age } \\
(\mathrm{Ma})\end{array}$ & $\begin{array}{c}\text { Depth } \\
\text { CCSF-A (m) }\end{array}$ & $\begin{array}{l}\text { Error } \\
(\mathrm{m})\end{array}$ & Event & $\begin{array}{l}\text { Age } \\
\text { (Ma) }\end{array}$ & $\begin{array}{c}\text { Depth } \\
\text { CCSF-A (m) }\end{array}$ & $\begin{array}{l}\text { Error } \\
(\mathrm{m})\end{array}$ \\
\hline $\mathrm{C} 1 \mathrm{n}-\mathrm{C} 1 \mathrm{r} .1 \mathrm{r}$ & 0.781 & 1.25 & & $\mathrm{C} 17 n .3 n-C 17 r$ & 38.159 & 98.60 & \\
\hline $\mathrm{C} 1 \mathrm{r} .1 \mathrm{r}-\mathrm{C} 1 \mathrm{r} .1 \mathrm{n}$ & 0.988 & 1.83 & & $\mathrm{C} 17 \mathrm{r}-\mathrm{C} 18 \mathrm{n} .1 \mathrm{n}$ & 38.449 & 99.85 & \\
\hline $\mathrm{C} 1 \mathrm{r} .1 \mathrm{n}-\mathrm{C} 1 \mathrm{r} .2 \mathrm{r}$ & 1.072 & 2.33 & & $\mathrm{C} 18 n .1 n-C 18 n .1 r$ & 39.554 & 107.92 & \\
\hline$C 1 r .2 r-C 2 n$ & 1.778 & 5.46 & & $\mathrm{C} 18 \mathrm{n} .1 \mathrm{r}-\mathrm{C} 18 \mathrm{n} .2 \mathrm{n}$ & 39.602 & 108.62 & \\
\hline$C 2 n-C 2 r .1 r$ & 1.945 & 5.91 & & $\mathrm{C} 18 \mathrm{n} .2 \mathrm{n}-\mathrm{C} 18 \mathrm{r}$ & 40.084 & 112.37 & \\
\hline $\mathrm{C} 2 \mathrm{r} .1 \mathrm{r}-\mathrm{C} 2 \mathrm{r} .1 \mathrm{n}$ & 2.128 & 6.71 & & $\mathrm{C} 18 \mathrm{r}-\mathrm{C} 19 \mathrm{n}$ & 41.358 & 125.02 & \\
\hline$C 2 r .1 n-C 2 r .2 r$ & 2.148 & 6.78 & & C19r-C20n & 42.536 & 136.22 & \\
\hline C2r.2r-C2An.1n & 2.581 & 8.58 & & \multirow{2}{*}{\multicolumn{4}{|c|}{ Nannofossils }} \\
\hline C2An.1n-C2An.1r & 3.032 & 9.73 & & & & & \\
\hline C2An.1r-C2An.2n & 3.116 & 10.03 & & T Sphenolithus delphix & 23.1 & 23.91 & 0.26 \\
\hline C2An.2n-C2An.2r & 3.207 & 10.33 & & B Sphenolithus delphix & 23.2 & 25.16 & 0.01 \\
\hline C2An.2r-C2An.3n & 3.330 & 10.63 & & X T. longus/T. carinatus & 24.7 & 28.40 & 0.75 \\
\hline C2An. $3 n-C 2 A r$ & 3.596 & 11.26 & & Tc Cyclicargolithus abisectus & 24.7 & 28.40 & 0.75 \\
\hline C6An.1r-C6An.2n & 20.439 & 15.23 & & T Sphenolithus predistentus & 26.9 & 36.98 & 1.38 \\
\hline C6An.2n-C6Ar & 20.709 & 15.98 & & T Sphenolithus pseudoradians & 28.8 & 42.10 & 0.75 \\
\hline C6Ar-C6AAn & 21.083 & 16.93 & & B Sphenolithus distentus & 30.0 & 55.00 & 0.75 \\
\hline C6AAn-C6AAr.1r & 21.159 & 17.05 & & T Reticulofenestra umbilicus & 32.0 & 68.34 & 0.74 \\
\hline C6AAr.1r-C6AAr.1n & 21.403 & 17.98 & & T Coccolithus formosus & 32.9 & 74.15 & 0.75 \\
\hline C6AAr.1n-C6AAr.2r & 21.483 & 18.18 & & T Discoaster saipanensis & 34.4 & 82.63 & 4.20 \\
\hline C6AAr.2r-C6AAr.2n & 21.659 & 18.70 & & T Chiasmolithus grandis & 37.1 & 100.17 & 0.75 \\
\hline C6AAr.2n-C6AAr.3r & 21.688 & 18.83 & & B Dictyococcites bisectus & 38.0 & 104.63 & 2.79 \\
\hline C6AAr.3r-C6Bn.1n & 21.767 & 19.05 & & T Chiasmolithus solitus & 40.4 & 112.50 & 5.08 \\
\hline C6Bn.1n-C6Bn.1r & 21.936 & 19.28 & & T Nannotetrina & 42.3 & 136.54 & 0.72 \\
\hline C 6 Bn. $1 r-C 6 B n .2 n$ & 21.992 & 19.85 & & B Reticulofenestra umbilicus $>14 \mu \mathrm{m}$ & 42.5 & 138.68 & 0.88 \\
\hline $\mathrm{C} 6 \mathrm{Bn} .2 \mathrm{n}-\mathrm{C} 6 \mathrm{Br}$ & 22.268 & 20.48 & & T Nannotetrina fulgens & 43.4 & 141.69 & 0.39 \\
\hline $\mathrm{C} 6 \mathrm{Br}-\mathrm{C} 6 \mathrm{Cn} .1 \mathrm{n}$ & 22.564 & 22.15 & & B Nannotetrina fulgens & 46.8 & 150.32 & 0.41 \\
\hline C6Cn.1n-C6Cn.1r & 22.754 & 22.80 & & T Discoaster lodoensis & 48.4 & 155.24 & 4.32 \\
\hline C 6 Cn. $1 r-C 6 C n .2 n$ & 22.902 & 22.90 & & \multicolumn{4}{|l|}{ Radiolarians } \\
\hline C 6 Cn.2n-C 6 Cn.2r & 23.030 & 23.05 & & B Cyrtocapsella cornuta & 22.26 & 21.69 & 1.48 \\
\hline C 6 Cn.2r-C 6 Cn.3n & 23.278 & 23.30 & & T Artophormis gracilis & 22.62 & 21.69 & 2.35 \\
\hline C $6 \mathrm{Cn} .3 \mathrm{n}-\mathrm{C} 6 \mathrm{Cr}$ & 23.340 & 23.58 & & B Lychnocanoma elongata & 25.05 & 27.16 & 0.99 \\
\hline $\mathrm{C} 6 \mathrm{Cr}-\mathrm{C} 7 \mathrm{n} .1 \mathrm{n}$ & 24.022 & 26.75 & & T Dorcadospyris circulus & 26.17 & 33.24 & 2.13 \\
\hline C7n.1n-C7n.1r & 24.062 & 26.85 & & B Dorcadospyris ateuchus & 29.50 & 51.61 & 1.50 \\
\hline C7n.1r-C7n.2n & 24.147 & 27.10 & & B Dorcadospyris circulus & 29.96 & 55.24 & 2.26 \\
\hline$C 7 n \cdot 2 n-C 7 r$ & 24.459 & 28.23 & & $\mathrm{~T}$ Theocyrtis tuberosa & 30.13 & 61.46 & 1.71 \\
\hline C7r-C7An & 24.756 & 29.05 & & T Lithocyclia crux & 30.13 & 61.46 & 1.71 \\
\hline C7An-C7Ar & 24.984 & 29.48 & & B Eucyrtidium plesiodiaphanes & 30.37 & 61.46 & 1.71 \\
\hline C7Ar-C8n.1n & 25.110 & 30.05 & & T Lophocyrtis oberhaensliae & 30.74 & 64.81 & 1.51 \\
\hline C8n.1n-C8n.1r & 25.248 & 30.43 & & T Lychnocanoma babylonis & 33.75 & 78.63 & 1.49 \\
\hline C $8 n .1 r-C 8 n .2 n$ & 25.306 & 30.55 & & T Thyrsocyrtis tetracantha & 35.30 & 84.78 & 0.33 \\
\hline $\mathrm{C} 8 \mathrm{n} \cdot 2 \mathrm{n}-\mathrm{C} 8 \mathrm{r}$ & 26.032 & 32.83 & & B Calocyclas bandyca & 36.74 & 90.95 & 2.28 \\
\hline $\mathrm{C} 8 \mathrm{r}-\mathrm{C} 9 \mathrm{n}$ & 26.508 & 34.55 & & B Lophocyrtis jacchia & 37.06 & 94.10 & 1.02 \\
\hline $\mathrm{C} 9 n-\mathrm{C} 9 \mathrm{r}$ & 27.412 & 39.05 & & B Cryptocarpium azyx & 37.52 & 95.28 & 1.50 \\
\hline C9r-C10n.1n & 27.886 & 41.05 & & B Calocyclas turris & 38.67 & 105.89 & 1.47 \\
\hline C10n.1n-C10n.1r & 28.126 & 42.05 & & B Lithocyclia aristotelis group & 39.73 & 108.98 & 1.50 \\
\hline C10n.1r-C10n.2n & 28.164 & 42.43 & & B Dorcadospyris anastasis & 39.98 & 112.38 & 2.00 \\
\hline $\mathrm{C} 10 \mathrm{n} \cdot 2 \mathrm{n}-\mathrm{C} 10 \mathrm{r}$ & 28.318 & 42.85 & & B Podocyrtis goetheana & 40.16 & 112.38 & 2.00 \\
\hline C10r-C11n.1n & 29.166 & 49.05 & & T Podocyrtis trachodes & 41.23 & 130.85 & 1.03 \\
\hline C11n.1n-C11n.1r & 29.467 & 51.60 & & B Podocyrtis chalara & 41.54 & 133.47 & 1.51 \\
\hline C11n.1r-C11n.2n & 29.536 & 51.83 & & B Cryptocarpium ornatum & 42.10 & 136.27 & 1.42 \\
\hline $\mathrm{C} 11 \mathrm{n} .2 \mathrm{n}-\mathrm{C} 11 \mathrm{r}$ & 29.957 & 53.93 & & T Eusyringium lagena & 42.69 & 140.21 & 1.54 \\
\hline $\mathrm{C} 11 \mathrm{r}-\mathrm{C} 12 \mathrm{n}$ & 30.617 & 57.23 & & B Podocyrtis helenae & 44.14 & 141.61 & 3.52 \\
\hline $\mathrm{C} 12 \mathrm{r}-\mathrm{C} 13 \mathrm{n}$ & 33.232 & 75.18 & & T Podocyrtis phyxis & 44.44 & 144.37 & 0.75 \\
\hline $\mathrm{C} 13 n-\mathrm{C} 13 \mathrm{r}$ & 33.705 & 78.11 & & T Podocyrtis diamesa & 44.44 & 144.37 & 0.75 \\
\hline $\mathrm{C} 13 \mathrm{r}-\mathrm{C} 15 \mathrm{n}$ & 35.126 & 82.31 & & T Spongatractus balbis & 44.77 & 147.83 & 2.71 \\
\hline $\mathrm{C} 15 \mathrm{r}-\mathrm{C} 16 \mathrm{n} .1 \mathrm{n}$ & 35.328 & 84.73 & & B Podocyrtis mitra & 44.77 & 147.83 & 2.71 \\
\hline$C 16 n .1 n-C 16 n .1 r$ & 35.554 & 85.53 & & B Podocyrtis ampla & 44.77 & 147.83 & 2.71 \\
\hline$C 16 n .1 r-C 16 n .2 n$ & 35.643 & 86.11 & & \multicolumn{4}{|l|}{ Foraminifers } \\
\hline C16n.2n-C16r & 36.355 & 89.38 & & T Paragloborotalia opima & 26.9 & 33.08 & 5.90 \\
\hline C16r-C17n.1n & 36.668 & 90.88 & & B Globigerina angulisuturalis & 29.2 & 44.49 & 5.52 \\
\hline $\mathrm{C} 17 \mathrm{n} .1 \mathrm{n}-\mathrm{C} 17 \mathrm{n} .1 \mathrm{r}$ & 37.520 & 95.87 & & T Subbotina angiporoides & 29.8 & 53.25 & 3.24 \\
\hline C17n.1r-C17n.2n & 37.656 & 96.25 & & B Paragloborotalia opima & 30.8 & 53.25 & 3.24 \\
\hline $\mathrm{C} 17 n \cdot 2 n-C 17 n .2 r$ & 37.907 & 97.40 & & & & & \\
\hline C17n.2r-C17n.3n & 37.956 & 97.70 & & & & & \\
\hline
\end{tabular}

Note: $\mathrm{T}=$ top, $\mathrm{B}=$ bottom, $\mathrm{X}=$ abundance crossover, $\mathrm{Tc}=$ top common. 
Table T36. Results from APCT-3 temperature profiles, Site U1332. (See table notes.)

\begin{tabular}{lccccc}
\hline & \multicolumn{2}{c}{ Temperature $\left({ }^{\circ} \mathrm{C}\right)$} & & & \\
\cline { 2 - 3 } Core & $\begin{array}{c}\text { Average } \\
\text { at } \\
\text { mudline }\end{array}$ & $\begin{array}{c}\text { Minimum } \\
\text { above } \\
\text { mudline }\end{array}$ & $\begin{array}{c}\text { Depth } \\
\text { DSF } \\
(\mathrm{m})\end{array}$ & $\begin{array}{c}\text { In situ } \\
\text { temperature } \\
\left({ }^{\circ} \mathrm{C}\right)\end{array}$ & $\begin{array}{c}\text { Thermal } \\
\text { resistance } \\
\left(\mathrm{m}^{2} \mathrm{~K} / \mathrm{m}\right)\end{array}$ \\
\hline 320-U1332B- & & & & & \\
2H & 1.569 & 1.458 & 11.6 & 1.77 & 14.4 \\
3H & 1.540 & 1.458 & 19.6 & 3.60 & 25.5 \\
5H & 1.527 & 1.453 & 38.6 & Undetermined & 46.5 \\
7H & 1.536 & 1.456 & 57.6 & 5.97 & 64.7 \\
9H & 1.515 & 1.458 & 76.6 & 7.05 & 81.3 \\
12H & 1.509 & 1.461 & 100.6 & 9.11 & 111.2 \\
320-U1332C- & & & & & \\
4H & 1.510 & 1.454 & 36.0 & 4.35 & 44.7 \\
9H & 1.518 & 1.450 & 75.5 & 7.00 & 80.3 \\
Average: & 1.528 & 1.456 & & & \\
\hline
\end{tabular}

Notes: In situ temperatures were determined using the TP-Fit software by Martin Heesemann. Thermal resistance was calculated from thermal conductivity data (see "Physical properties") corrected for in situ conditions (see "Downhole measurements" in the "Methods" chapter). 